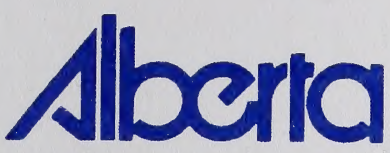

SUSTAINABLE RESOURCE

DEVELOPMENT
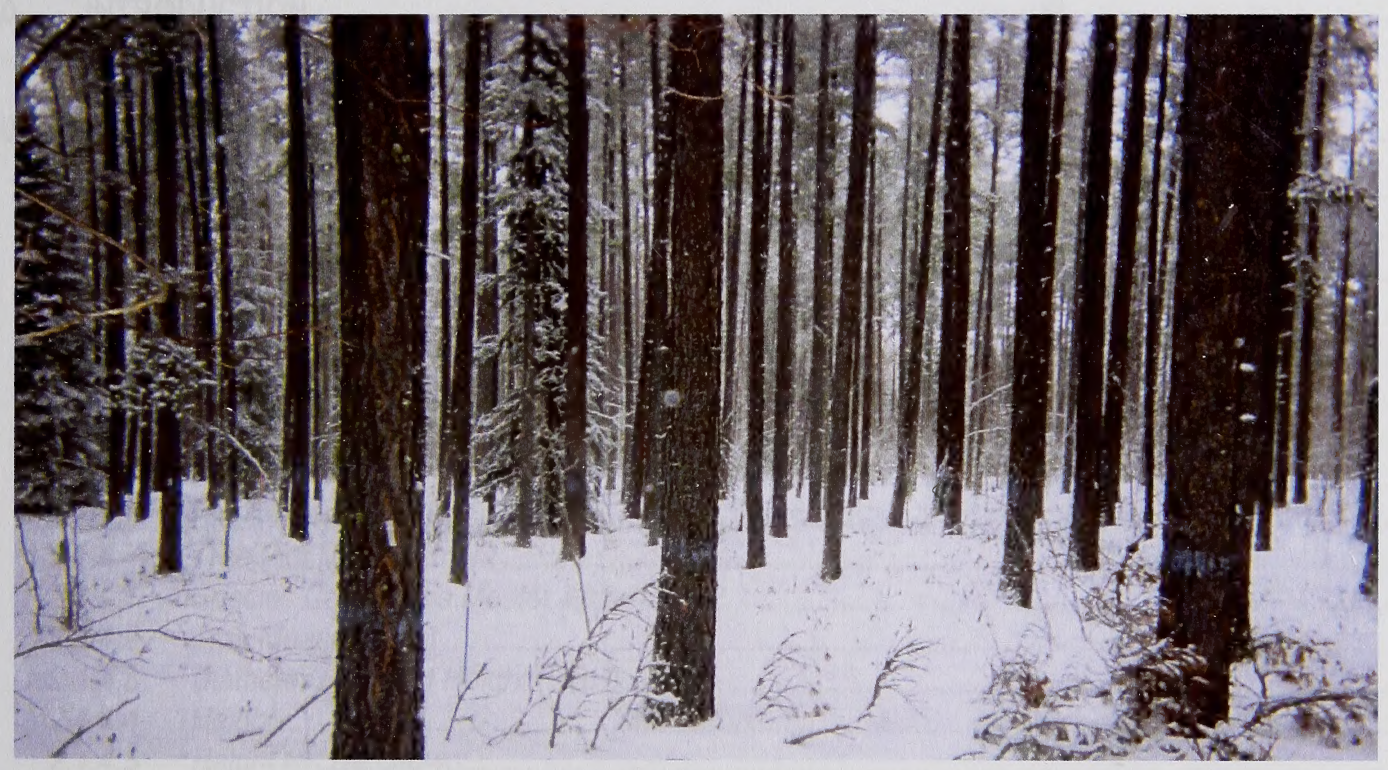

\title{
PERMANENT SAMPLE PLOT (PSP) FIELD PROCEDURES MANUAL
}

\section{March 2005}

Public Lands and Forests Division

Forest Management Branch

$8^{\text {th }} \mathrm{FI}$. 9920-108 Street

Edmonton, $\mathrm{AB}$

T5K 2M4

Phone: (780) 427 - 8474

Or visit the website: http://www3.gov.ab.ca/srd/forests/psp 
Digitized by the Internet Archive in 2016 


\section{TABLE OF CONTENTS}

$1.0 \quad$ INTRODUCTION

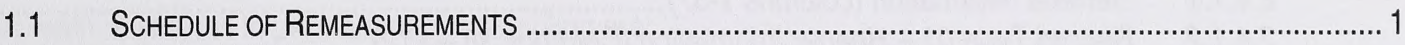

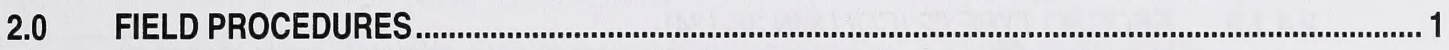

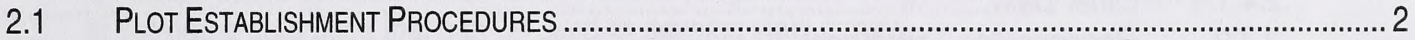

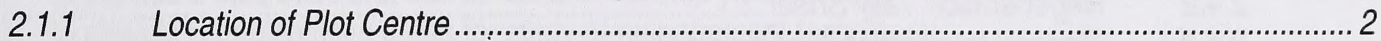

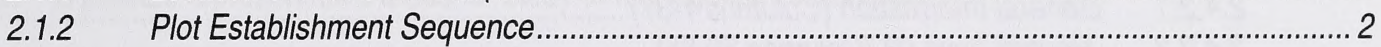

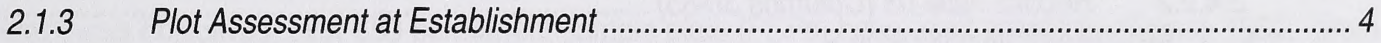

2.1.3.1 Plot Overstorey/ Understorey Covertypes ………......................................................... 4

2.1.3.2 Topography and Elevation ......................................................................................... 4

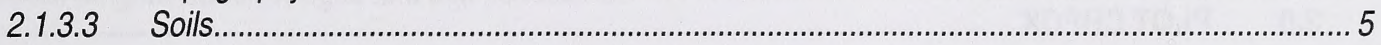

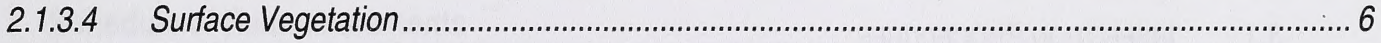

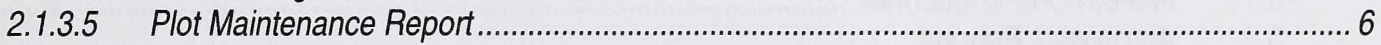

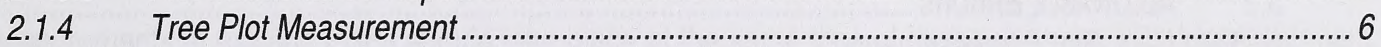

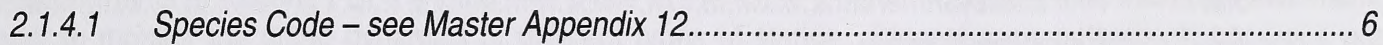

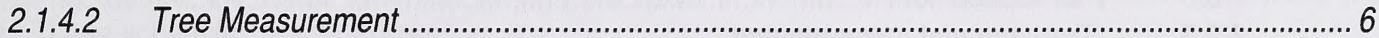

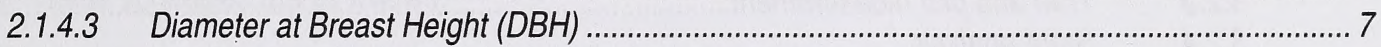

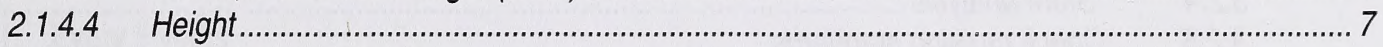

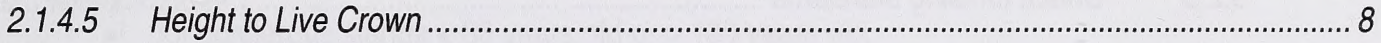

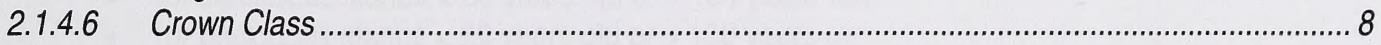

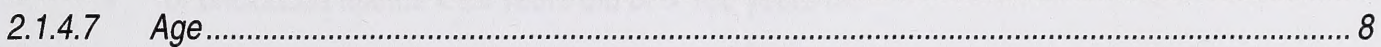

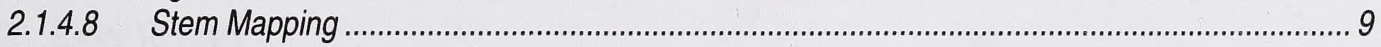

2.1.5 Sapling/Regen Plot Measurement .......................................................................... 9

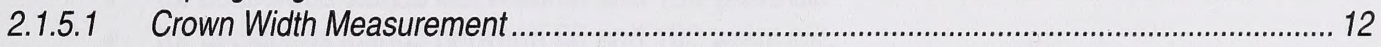

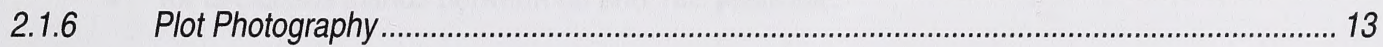

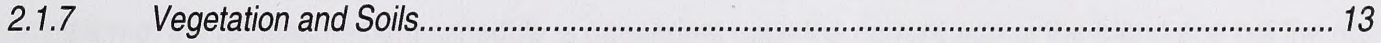

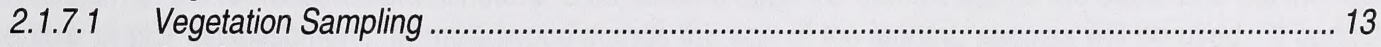

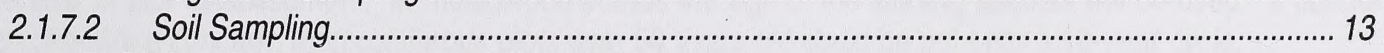

$2.2 \quad$ PLOT REMEASUREMENT PROCEDURES ……………….................................................... 14

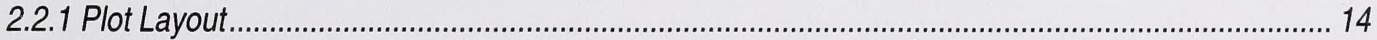

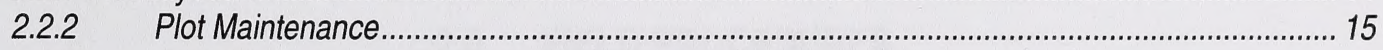

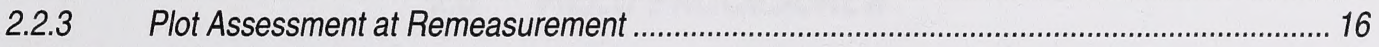

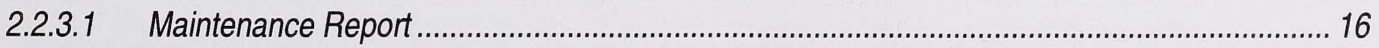

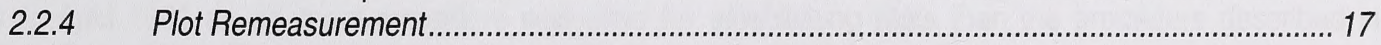

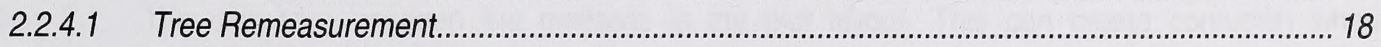

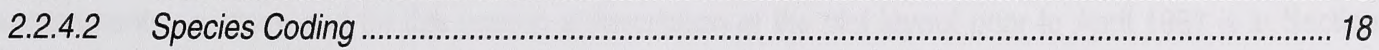

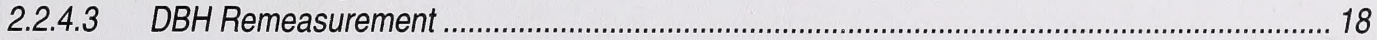

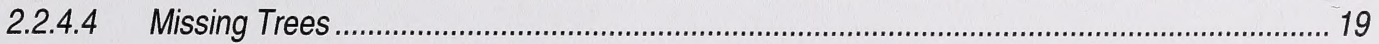


2.2.4.5 Ingrowth

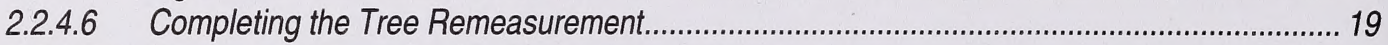

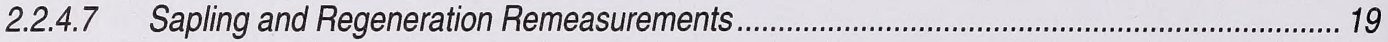

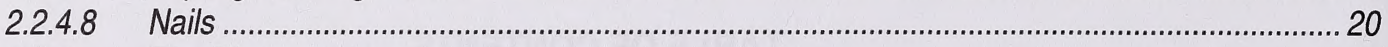

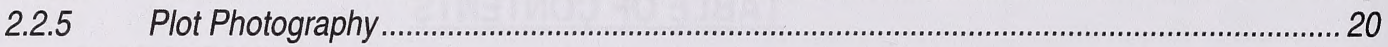

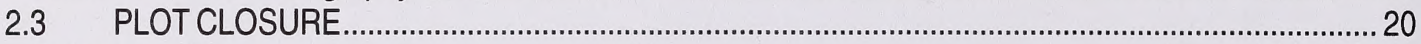

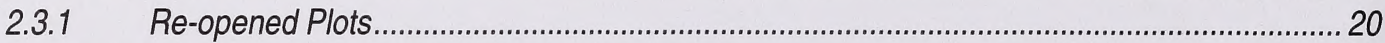

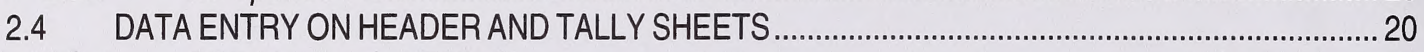

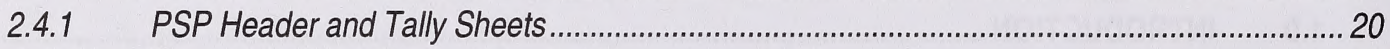

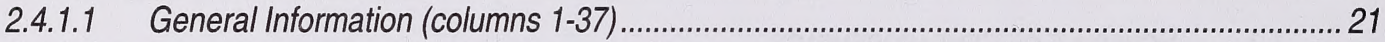

2.4.1.2 Record Type 01 - Header Information (Columns 38 - 212) ............................................... 21

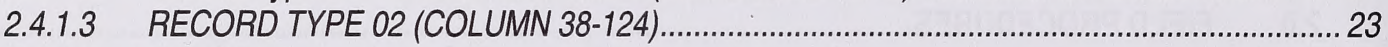

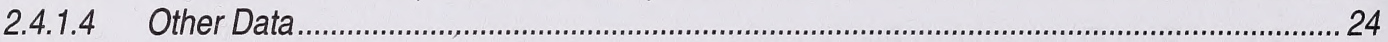

2.4.2 Regeneration Tally Sheet ....................................................................................... 25

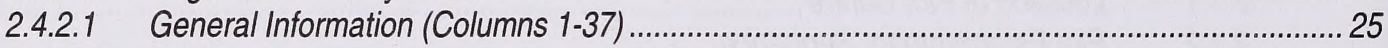

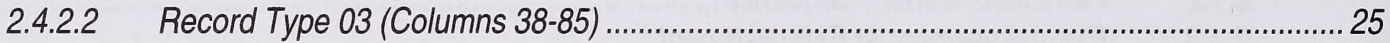

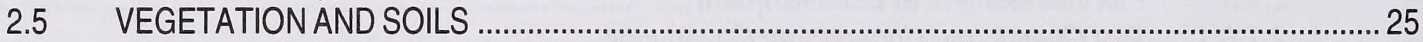

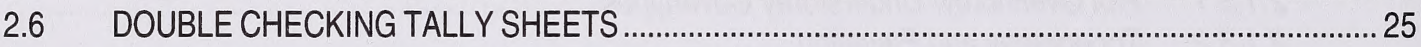

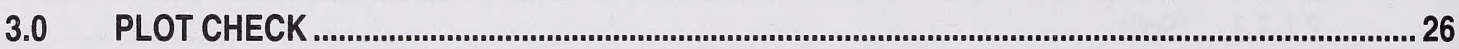

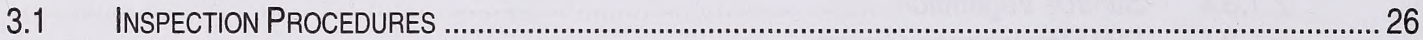

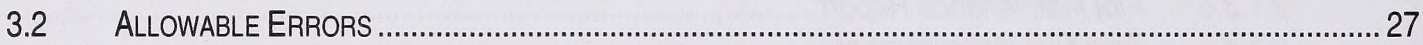

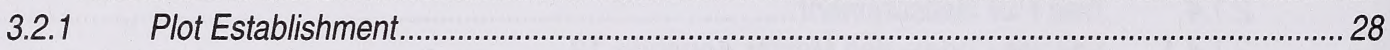

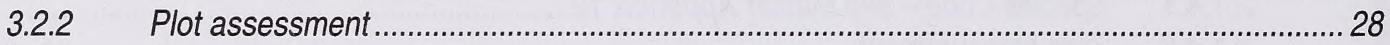

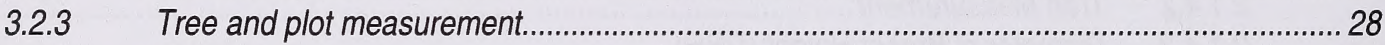

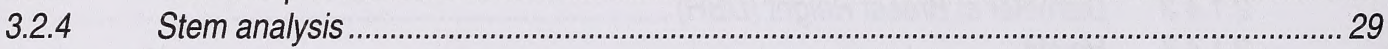

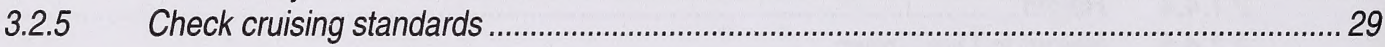




\subsection{INTRODUCTION}

In order to manage our forest resource effectively, we need to acquire a better understanding of stand dynamics, i.e. how trees grow and stands change over time. An accurate method of determining growth and yield is through the use of permanent sample plots (PSPs). The growth of a stand can be estimated directly by taking measurements of the same trees at periodic intervals. This information is vital in the establishment of a sustained yield program.

The main objectives in permanent plot sampling are:

1. to assess stand dynamics such as succession, regeneration, ingrowth and mortality

2. to provide a data base that can be used to develop yield curves

3. to provide representative areas for study of management techniques

To meet these objectives, over 650 permanent sample plots (PSPs) have been established since 1960. More PSPs will be needed (over 3000 in total) in order to provide representative information for a variety of densities, heights, species, ages and site conditions.

\subsection{Schedule of Remeasurements}

Remeasurements of existing PSPs should take place at the same time of the year as the initial establishment. In order to monitor the stand dynamics of different types of stands, different remeasurement schedules are used. These schedules are as follows:

1. Every 5 years

- for coniferous stands $<80$ years old or $>130$ years old.

- for deciduous stands $<60$ years old or $>100$ years old

2. Every 10 years

- for coniferous stands between 80 and 130 years old

- for deciduous stands between 60 and 100 years old.

Determination of the remeasurement schedule is dependent upon the current age of the stand and not the age at the time of plot establishment. In mixedwood stands the age of the leading species will be used. If budget constraints are a concern, then coniferous plots over 50 years old could be put onto a 10-year cycle.

\subsection{FIELD PROCEDURES}

Prior to April 1981 an alternate procedure was used for establishing plots than the procedure described in Section 2.1. The difference between the methods is the plot layout. This can create confusion when remeasurements are done and for this reason a description of the plot layout prior to April 1981 is in Section 2.2.1. 


\subsection{Plot Establishment Procedures}

The plot establishment procedures described in this section are for all plots established after April 1981.

\subsubsection{Location of Plot Centre}

The approximate location of the PSP should be pre-determined on a stand map. The selected stand must be large enough to ensure that the entire plot is within the desired cover type. After the preliminary map work is completed and a tie point (using a permanent land feature) has been selected, a pre-determined horizontal distance and azimuth is chosen to locate a potential plot centre and the ground plot centre is established. An aluminum tag, labelled with the PSP number and the word "CENTRE" (e.g. PSP456-CENTRE), is attached to the top of the post.

A tie-point is then established to link the plot centre to a permanent land feature on a Phase 3/AVI map for the purpose of locating the plot for future remeasurements. Section 2.2.2 deals with maintenance and establishment of tie-points. The tie-point information is then used to locate the plot on the aerial photographs and the forest cover type map. For tallying purposes, the legal land description is recorded as the section and legal subdivision containing the centre of the PSP group.

The following plot establishment sequence is used to establish a PSP with a plot size of $1 / 10$ hectare. Plot centres are Gpsed at least twice. Second time is to verify that the first GPS location is $\pm-3 m$.

\subsubsection{Plot Establishment Sequence}

The plot establishment sequence must be followed closely to orient the plot properly and to produce the nested sampling design. All posts and metal pins, for the regeneration and sampling plot corners, are to be tagged and labelled as shown in Figure 2.1.

To establish a one-tenth hectare plot, as shown in Figure 2.2, the following sequence is used.

1. Using a staff compass go on a bearing of 45 degree for $22.36 \mathrm{~m}$, from the centrepost and locate the NE corner of the tree plot. Pound a post into the ground at this point and attach a tag with the PSP number and "NE" corner marked on it (e.g. PSP\# 456-NE). An aluminum angle post are also placed into the ground at each corner post. It is pounded in the ground until at least $10 \mathrm{~cm}$ remains above ground.

Note: The centre metal post must be removed before the staff compass is used.

2. In the same manner locate the other 3 tree plot corners using the following bearings:

SE Corner - $135^{\circ}$

SW Corner - $225^{\circ}$

NW Corner $-315^{\circ}$ 
If possible, check the alignment of the plot (ie. a square with right angle corners) by standing at one corner and sighting through the centre to the opposite corner. The tree posts, NE, CENTRE and SW should form a straight line. If the posts do not line up they must be located until they do.

Note: All distances are horizontal distances (if slopes are $\geq 10 \%$ the distance must be corrected use the slopes correction factor tables in Appendix 4.5).

3. The length of each side is measured using a $50 \mathrm{~m}$ tape and must be $31.62 \mathrm{~m} \pm 0.25 \mathrm{~m}(31.37 \mathrm{~m}-$ $31.87 \mathrm{~m}$ ). Relocation of the corner posts is necessary if the length of a side falls outside this range. Record the distance of each side and each diagonal on the Plot Maintenance Report Figure 2.10. The tree plot boundaries and azimuth are determined by running string between corner posts. Care must be taken with borderline trees. A tree is considered "in" if more than half of the stem, at breast height, falls inside the plot.

4. A sapling/regeneration plot (1/16 the size of the plot) must be established even if there are no saplings or regeneration present. To establish the sapling/regen plot, place an aluminum angle post $11.18 \mathrm{~m}$, at an azimuth of $315^{\circ}$, from the plot centre. This marks the SE corner. The NE and SW corners of the sapling/regen plot are located by running lines north and west, respectively, from the SE corner to the tree plot boundary. Check the lengths of the plot to ensure that they are $7.9 \mathrm{~m} \pm 0.06 \mathrm{~m}(7.84 \mathrm{~m}-$ $7.96 \mathrm{~m})$. Attach a tag labeled with the PSP number, "SAP/REGEN, and the corner (e.g. PSP456SAP/REGEN-SE). The sapling/regen plot boundaries are defined with string to determine "in" and "out" stems.

5. The reservation boundary (buffer) is established by running a line, using a topofil, for $100 \mathrm{~m}$ at $360^{\circ}$ from plot center. Using blue paint, mark the trees, at $5 \mathrm{~m}$ to $10 \mathrm{~m}$ intervals, for $200 \mathrm{~m}$ in each of the cardinal directions creating a square shaped buffer surrounding the plot. Paint a small rectangle $22 \mathrm{~cm}$ $x 28 \mathrm{~cm}$, one -third of the circumference, on each tree, at eye level $(2 \mathrm{~m}$ above ground) facing away from the plot. To aid in the relocation of the buffer corners, paint every tree for the first $10 \mathrm{~m}$ and the last $10 \mathrm{~m}$ on each side of the buffer. The trees used for buffer corners should have "C"s painted on the two sides facing out from the plot. Also paint NW to indicate Northwest corner of buffer NE to indicate Northeast corner of buffer, etc. Avoid if possible painting dead trees, wind-blown trees and trees with thick, low-hanging branches. When remeasuring the plot, PSP blue tags (and/or Blue PSP flagging tied to the trees) are stapled above the blue painted trees. Repaint the blue trees and put blue tags on every $2^{\text {nd }}$ blue painted tree. Buffer is GPSed for mapping and GIS applications.

6. To assist in the future location and remeasurement of the plot, trees (called a witness trees), outside of the tree plot, at each tree plot corner is painted blue, on the side that faces in towards the plot centre.

In Summary:

Table 1

\begin{tabular}{|c|c|c|c|c|c|c|c|c|}
\hline \multicolumn{4}{|c|}{ Tree Plot } & \multicolumn{3}{c|}{ Sapling/Regen Plot } & \multicolumn{2}{c|}{ Buffer } \\
\hline $\begin{array}{c}\text { Area } \\
(\mathrm{ha})\end{array}$ & $\begin{array}{c}\text { Area } \\
\left(\mathrm{m}^{2}\right)\end{array}$ & $\begin{array}{c}\text { Side } \\
(\mathrm{m})\end{array}$ & $\begin{array}{c}\text { Diagonal } \\
(\mathrm{m})\end{array}$ & $\begin{array}{c}\text { Area } \\
(\mathrm{m})\end{array}$ & $\begin{array}{c}\text { Side } \\
(\mathrm{m})\end{array}$ & $\begin{array}{c}\text { Diagonal } \\
(\mathrm{m})\end{array}$ & $\begin{array}{c}\text { Area } \\
\left(\mathrm{m}^{2}\right)\end{array}$ & $\begin{array}{c}\text { Side } \\
(\mathrm{m})\end{array}$ \\
\hline 0.10 & 1,000 & 31.62 & 44.72 & 62 & 7.90 & 11.18 & 40,000 & 200.0 \\
\hline 0.15 & 1,500 & 38.73 & 54.77 & 94 & 9.69 & 13.70 & 56,250 & 237.0 \\
\hline 0.20 & 2,000 & 44.72 & 63.24 & 125 & 11.18 & 15.81 & 90,000 & 300.0 \\
\hline
\end{tabular}

Page 3 


\subsubsection{Plot Assessment at Establishment}

Plot assessment refers to plot data related to the physical characteristics of that area. Plot assessment is collected in the following categories using the given descriptions.

\subsubsection{Plot Overstorey/ Understorey Covertypes}

There are two kinds of plot covertypes recorded. The AVI Photo-Interpreted Overstorey and Understorey species codes are recorded only at plot establishment after all field work and mapping has been completed. The AVI Field Overstorey and AVI Understorey species codes are recorded in the shaded columns by field crews during plot establishment and remeasurement. The codes used for covertypes are listed in Section 2.1.4. The variables location, slope, aspect, elevation and soils information are only recorded at plot establishment.

\subsubsection{Topography and Elevation}

\section{Location}

Location refers to the relative topographic position of the plot, in a hydrological sense, when compared to the general immediate area surrounding the plot. The codes used for location (see Appendix 2a) are:

$$
\begin{aligned}
& \text { 1-Hollow } \\
& \text { 2-Flat } \\
& \text { 3-Slope } \\
& \text { 4-Hilltop }
\end{aligned}
$$

\section{Slope}

With the use of clinometer the average slope for the plot is recorded to the nearest \%. If theres is no slope, zero is recorded.

\section{Aspect}

Average aspect (the direction when facing away from the slope) of the plot recorded as N, NE, E, SE, S, SW, $\mathrm{W}$, or $\mathrm{N}$. (Note: if slope percent is zero, make note in comments section).

\section{Elevation}

Elevation is recorded as the height above the sea level to the nearest metre and is taken at the PSP group/plot centre. The contour line closest to the plot location on a National Topographic System (NTS) map is recorded in the comments section on the PSP Header Sheet to act as a guide for field elevation reading. In order to obtain an accurate reading, the altimeter must be set daily at a location with a known elevation (e.g. airstrip, benchmark, etc.) This elevation is recorded (Reading 1) in the comments section on the header sheet. Upon entering the PSP, the elevation is read and recorded (Reading 2) in the columns $77-80$ allocated in the header and may be subject to change. The altimeter is read (Reading 3 ) once again at the location with the known elevation. The average difference between Reading 3 and Reading 1 is added to Reading 2 to obtain the final elevation of the plot. If the final calculated elevation differs from the field reading (Reading 2), the Header sheet must have the elevation record changed. 
e.g. First reading at known elevation $=1000 \mathrm{~m}$ (Reading 1 )

$$
\text { PSP elevation } \quad=1500 \mathrm{~m} \text { (Reading 2) }
$$

Final Reading at know elevation $=980 \mathrm{~m}$ (Reading 3 )

$$
\begin{aligned}
& \frac{\text { Reading } 3-\text { Reading } 1}{2}+\text { Reading } 2=\text { Final PSP elevation } \\
& \begin{aligned}
\frac{980 m-1000 m}{2}+1500 m & =-10 m+1500 m \\
& =1490 m \text { (final calculated elevation) }
\end{aligned}
\end{aligned}
$$

Reading 2 is not to be changed if Reading 3 is drastically different from Reading 1 due to changes in barometric pressure (e.g. a storm front has come through since Reading 1 was set).

\subsubsection{Soils}

\section{Erosion Potential}

This describes the chance of water eroding down to or into the mineral soil layer. This is a based upon water flow, slope, and soil type. The codes used for erosion potential (see Appendix 3a) are:

$$
\begin{aligned}
& 1 \text { - Slight } \\
& 2 \text { - Moderate } \\
& 3 \text { - High }
\end{aligned}
$$

\section{Drainage}

Soil drainage is assessed by evaluating the plot position, soil texture, humus depth, location of the water table, permeability and water storage capacity. The codes used for soil drainage (see Appendix 3b) are:

$$
\begin{aligned}
& 1 \text { - Very rapidly drained } \\
& 2 \text { - Rapidly drained } \\
& 3 \text { - Well drained } \\
& 4 \text { - Moderately well drained } \\
& 5 \text { - Imperfectly drained } \\
& 6 \text { - Poorly Drained } \\
& 7 \text { - Very poorly drained }
\end{aligned}
$$

\section{Depth of Mineral Soil}

The average depth of the duff layer (organic matter) to the mineral soil (or the water table in boggy conditions) is recorded to the nearest centimetre. 


\subsubsection{Surface Vegetation}

\section{Type}

There are nine possible types or combinations of grass, lichen/moss, herbs (flowers and non-woody stems) and shrubs (woody stems). The dominant vegetation type is recorded.

$$
\begin{aligned}
& 1 \text { - Grass } \\
& 2 \text { - Grass and herbs } \\
& 3 \text { - Grass and shrubs } \\
& 4 \text { - Lichen/moss } \\
& 5 \text { - Lichen/moss and herbs } \\
& 6 \text { - Lichen/moss and shurbs } \\
& 7 \text { - Herbs } \\
& 8 \text { - Herbs and shrubs } \\
& 9 \text { - Shrubs }
\end{aligned}
$$

\section{Ground Cover}

The percent of the ground that is covered by surface vegetation is recorded to the nearest percent. In most cases this will be, or very close to, $100 \%$. Plots with a lot of surface rock, woody material or water will have a lower percent of ground cover. A comment why cover is not $100 \%$ must be made on the comments section of the header sheet.

\subsubsection{Plot Maintenance Report}

The maintenance report data is recorded on both plot established and plot remeasurement. Refer to Section 2.2.3.1 for information on access, plot damage and buffer damage.

\subsubsection{Tree Plot Measurement}

All standing trees (live and dead) $\geq 9.1 \mathrm{~cm}$ DBH (diameter at breast height) within the tree plot are tagged, measure, and tallied. Any standing dead trees must be capable of withstanding a firm push before being measured (standing dead trees are tagged at establishment to assist in plot remeasurement and for possible use in growth modeling).

If for some reason this $1 / 16$ sapling/regen plot is not representative of the plot, a note must be made in the comments section indicating this is the case but sapling are still tagged and measured.

\subsubsection{Species Code - see Master Appendix 12}

\subsubsection{Tree Measurement}


In order to aid in the tally of the trees within the tree plot, the plot is divided into four north-south strips, called swaths. Each swath is approximately $1 / 4$ the width of the plot, runs the length of the plot and is defined with strings as shown in Figure 2.3. Swaths are marked with topophil string as shown in Figure 2.3, Swaths are marked with topophil string and/or yellow geo flagging.

All talliable trees are tagged (numbered from 1 to 9997) starting with the tree closest to the NW corner post. Trees are numbered consecutively from side to side within each swath in a forward direction. Tags on the trees tallied in the southern direction are tagged on the south side of the tree (see Figure 2.3). By tagging trees in this manner, remeasurement is simplified and plots are easier to locate as tags can be seen when entering the plot from any direction.

Tags are nailed to the tree/saplings at exactly breast height (see Section 2.1 .4 .3$)$ using $6.5 \mathrm{~cm}(2.1 / 2 \mathrm{inch}$ ) spiral nails. Nails must have the head sloped slightly downwards and pounded until $2.5-3.5 \mathrm{~cm}$ remain outside of the tree. This will keep the tags secure and not grown over by the tree. The tree numbers are to be written vertically on the tree tags (see Figure $2.3 \mathrm{~B}$ ). Wire is to be used on deciduous trees because they do not take nails well. Leave lots of room.

\subsubsection{Diameter at Breast Height (DBH)}

Breast height is 1.3 metres from the point of germination as shown in Figure 2.4. A blue bar is painted at DBH also.

Breast height is determined using a straight stick $1.3 \mathrm{~m}$ long. Using a metal diameter tape, measure the tree's diameter to the nearest $0.1 \mathrm{~cm}$ making sure the tape is perpendicular to the stem. Diameters are always taken directly above the nail unless there are large branches or swelling right at breast height. These defects are to be avoided and the diameter is taken immediately above or below the distortion and a comment noting the problem is made. Also see appendix \#14 for determining breast height. An example on the tally sheet is the comments section (e.g. DBH taken below swell). See Figure 2.14, tree\#1.

\subsubsection{Height}

With the advent of electronic height measuring devices it was decided that in 1998, the heights of all trees (alive) will be taken. Height to top live branches on trees that have damaged tops.

All height trees are to be marked at breast height with any colour of geo-flagging tape. As well a blue painted dot facing the direction in which the cruiser went in order to complete the height measurement shall be put on each height tree. The dot should be no longer than $5 \mathrm{~cm}$ in diameter and must be located between $.75 \mathrm{~m}-10$ from the ground. Do not measure the height of standing dead trees even if it was a sample tree last remeasurement. Do not measure height on dead and down trees. See Master Appendix for tree height measurement methodology.

For office purposes and a method of checking field calculations record the tree number, species, top $\%$, top $\%$ to live crown, and bottom \% readings, (slope distance and slope \% when applicable) on the back of the tally sheet (see Figure 4.2A). To be done if measuring with clinometer and loggers tape. If heights taken with an 
electronic height finder, record person and type of machine on back of tally sheet. The space allocated for correction is used when a bottom percentage reading cannot be taken for the base of the tree and a known height (ie. DBH) or measured height must be used (this correction must be added to the calculated height to get total height). In addition, the calculated net percentage, horizontal distance, and total height should be recorded for each tree. The calculated heights are to be transferred onto the front of the tally sheet in the appropriate columns.

\subsubsection{Height to Live Crown}

The height from the ground to the base of the live crown (see Figure 2.5) is measured on all trees that have been measured for total height. The base of the live crown is the point that separates the continuously branched portion of the tree and the part that has sporadic or no branching. Live crowns on deciduous species start at the leaves, not at the branches. Live crowns on coniferous species start at the tip of the live branch, not at the base of the branch. The height to live crown is quite variable depending on stand maturity and density with young, open stands having low live crowns and mature, stocked stands having higher, live crowns. Height to live crown is measured on age trees when they are on the ground and being prepared for sectioning.

\subsubsection{Crown Class}

Crown class (CC) refers to the position of an individual tree within the canopy of the stand inside the plot. Crown class is assessed on a plot-by-plot basis, not on the stand as a whole. For example, an intermediate tree in one PSP plot may be codominant in the next. The following figure shows the types of crown class in a single layer stand. Crown classes are recorded for all tress with the exception of those with a broken top/system, are dead, cut down, missing, or have a severe lean (see Figure 2.6).

\subsubsection{Age}

The age of a PSP is determined by felling and sectioning a minimum of three codominant/dominant trees of each major species found within the plot. The selected trees are found outside the plot inside the reservation boundary (buffer) and the same stand types as the plot. When selecting trees for sectioning, preference should be given to healthy trees. Trees are sectioned in accordance with the Public Lands and Forests Division Tree Sectioning Procedure Manual and tallied on the Tree Sectioning Tally Sheet (CSTM 04 or CSTM 04A). Information pertaining to species, DBH, height, height to live crown, crown class, and condition codes are transferred onto the PSP Header Sheet under tree number 0000. For each sectioned tree the DBH age, stump age, and stump increments for $0-10$ years and $10-20$ years are also recorded. See Figure 2.7.

Refer to Section 4.11 for special measurements for immature and mistletoe plots.

The three stump ages for each species must be within a ten-year frame of each other or more trees must be felled (i.e. 90-100-110 represents a 20 year gap - need to fall 1 more tree with an age between 90-100 or 100110; 96-99-104 represents an 8 year gap - no more trees need to be felled). The cookies should be marked with the plot number and tree number, then taken back to the field office for verification. Care must be taken 
with aging as some species, such as aspen, can have false rings that may result in inaccurate age counts. This would affect growth and yield calculations. Approximate locations of sectioned trees shall be indicated with an "X" on the maintenance report. As well, yellow geo-flagging shall be used to indicate the field locations.

\subsubsection{Stem Mapping}

All tagged stems within the tree sapling plot are stem mapped. Stem mapping is used to identify the position of each tree or sapling with respect to other surrounding trees or sapling and can be used in distance dependent growth models and is used in plot remeasurement to locate missing trees or sapling.

A staff compass and a metric tape is used to determine the azimuth and distance to the centre of each tree or sapling, at breast height, from the plot centre. Azimuth are recorded from $1^{\circ}-360^{\circ}$ and distances are measured to the nearest $0.1 \mathrm{~m}$. Standing dead trees are to be stem mapped.

Regeneration are not stem mapped.

\subsubsection{Sapling/Regen Plot Measurement}

\section{Sapling/Regeneration History}

1968

During re-measurements in 1968, saplings were measured and recorded for the first time. Saplings were considered to be all stems inside the tree plot with a diameter at breast height (DBH) of $0.1-0.6$ inches. However, saplings were not measured in every PSP or even in every subplot of a PSP. When saplings were tallied, they were termed "regeneration".

Regeneration has been tallied by height class and species since 1960. All regeneration within a subplot were counted until 1981.

1981

Sapling plot sizes are required to be $1 / 4$ the size of the tree plot while regeneration plot sizes are $1 / 16$ of the tree plot. The 900 series drainage plots and 700 series immature plots are also exceptions. These dimensions are used for all subplots for field measurements unless there are over 100 saplings in the sapling plot. When this occurs the sapling plot is reduced to the regeneration plot. (See table on plot sizes) 


\section{PLOT SIZES}

\begin{tabular}{|c|c|c|c|c|c|c|c|}
\hline \multirow[b]{2}{*}{$\begin{array}{c}\text { Year of } \\
\text { establishment }\end{array}$} & \multicolumn{3}{|c|}{ TREE PLOT } & \multicolumn{2}{|c|}{ SAPLING PLOT } & \multicolumn{2}{|c|}{ REGENERATION PLOT } \\
\hline & Area (ac.) & $\left(m^{2}\right)$ & $\begin{array}{l}\text { Length of } \\
\text { Side }(\mathrm{m})\end{array}$ & Area $\left(m^{2}\right)$ & $\begin{array}{l}\text { Length of } \\
\text { Side }(m)\end{array}$ & Area $\left(m^{2}\right)$ & $\begin{array}{l}\text { Length of } \\
\text { Side }(m)\end{array}$ \\
\hline \multirow[t]{6}{*}{$1960-1981$} & $1 / 20$ & 202 & 14.23 & 50 & 7.11 & 13 & 3.56 \\
\hline & $1 / 10$ & 405 & 20.12 & 101 & 10.06 & 25 & 5.03 \\
\hline & $1 / 8$ & 506 & 22.49 & 126 & 11.25 & 32 & 5.62 \\
\hline & $1 / 5$ & 809 & 28.45 & 202 & 14.23 & 50 & 7.11 \\
\hline & $1 / 4$ & 1012 & 31.81 & 253 & 15.9 & 63 & 7.95 \\
\hline & $1 / 2$ & 2023 & 44.98 & 506 & 22.49 & 127 & 11.25 \\
\hline \multirow[t]{4}{*}{ Post 1981} & & 1000 & 31.62 & 250 & 15.81 & 62 & 7.90 \\
\hline & & 1500 & 38.73 & 375 & 19.37 & 94 & 9.69 \\
\hline & & 2000 & 44.72 & 500 & 22.36 & 125 & 11.18 \\
\hline & & 2000 & $40 \times 5$ & - & - & 25 & 5.00 \\
\hline
\end{tabular}

Saplings were not numbered until 1981. Since this time all saplings inside the sampling plots within all subplots are assigned tree number 9999 . Saplings will be numbered 9999 from 1981 until the year 2000 when the saplings actual got a tree numbers starting at 8001 (see following page 2000 field season).

PSP's established in immature stands since 1989 (700 series) have sequential numbers assigned to each sapling within the sapling plot. These saplings are not distinguishable from trees in the PSP by number.

Regeneration was also supplied with a number in 1981. For tallying purposes all regeneration, inside the regeneration plots, are recorded as tree number 9998 . This record is a dot tally and was recorded for each species.

\section{Tree, Sapling and Regeneration Specifications}

When PSP's were first established, all stems inside a subplot boundary were considered either trees or regeneration. The specification of a tree was any stem with a DBH of 0.6 inches or greater and regeneration was all stems less than 0.6 inches DBH to a minimum height of 0.5 feet. With this system, some subplots contained a large number of trees that contained very little volume.

In 1981, the specifications for trees, saplings, and regeneration were developed. Trees were defined as all stems with a DBH of $9.1 \mathrm{~cm}$ or more. Saplings were determined to be all stems with a DBH greater than 1.1 
$\mathrm{cm}$ and less than $9.1 \mathrm{~cm}$. All stems less than $1.1 \mathrm{~cm} \mathrm{DBH}$ but taller than $0.16 \mathrm{~m}$ in height were defined as regeneration.

In the 900 series of drainage plots the sapling category was not used. All stems greater than $1.1 \mathrm{~cm} \mathrm{DBH}$ were considered trees. No sapling plots were established in these plots.

The regeneration height classes were changed from the original 1960 specifications in 1981 and again in 1983. In the initial change, the height classes were converted from imperial to metric units and were labeled, using the midpoint of each height class and increased from six classes to ten. The 1983 alteration reduced the number of height classes from ten to five and again listed each class using a height range. Each of these classes was assigned a number. The following table is a summary of the changes made to the regeneration height classes.

\begin{tabular}{|c|cc||cc|}
\hline $\begin{array}{c}1960-1980 \\
(\mathrm{ft} .)\end{array}$ & $(\mathrm{m})$ & Midpoint $(\mathrm{m})$ & \multicolumn{2}{c|}{1983 - present } \\
\hline $0.5-1.4$ & $0.1-0.44$ & 0.3 & $0.10-0.30$ & Height class \\
$1.5-2.4$ & $0.45-0.74$ & 0.6 & $0.31-0.60$ & 2 \\
$2.5-3.4$ & $0.75-1.04$ & 0.9 & $0.61-0.90$ & 3 \\
$4.5-5.4$ & $1.05-1.34$ & 1.2 & $0.91-1.20$ & 4 \\
$5.5-6.4$ & $1.35-1.64$ & 1.5 & $1.20+$ & 5 \\
$6.5-7.4$ & $1.65-1.94$ & 1.8 & & \\
& $1.95-2.24$ & 2.1 & & \\
& $2.25-2.54$ & 2.4 & \\
& $2.55-2.84$ & 2.7 & \\
& $2.85+$ & 3.0 & \\
\hline
\end{tabular}

1991

Sapling and regen plots combined. Only the regen plot size is used now (1/16 of plot/sub-plot size).

\section{0}

Starting in 2000 field season, sapling located in the 1/16 sapling/regen plot will be measured and tagged just like trees in the tree plot. Any tree that has a height of $=>1.3 \mathrm{~m}$ will be measured, tagged, azimuth and distance taken, etc. All stems $\geq 0.10 \mathrm{~m}$ in height up to $1.29 \mathrm{~m}$ inside the sapling/regen plot are tallied as regen. Note that on 700 series type plots (immature) all saplings are already tagged. Trees that are $\geq 1.3 \mathrm{~m}$ in height are now included, a minimum DBH is not required. These saplings are numbered starting at 8001,8002 ,etc.

Saplings are to be measured exactly as a tree if they fall within the $1 / 16$ sapling /regen plot. Saplings are $=>1.3 \mathrm{~m}$ in height. The numbering on sapling start at 8001,8002 , etc. Regeneration (regen) is classified as 
any stem $0.10 \mathrm{~m}$ or taller to a maximum Height of $<=1.29 \mathrm{~m}$. Regen is counted by species and height class and recorded on the regeneration tally sheet (see Figure 2.15 ) using a standard dot tally.

The five height classes are as follows:

Class 1: $0.10-0.30 \mathrm{~m}$

Class 2: $0.31-0.60 \mathrm{~m}$

Class 3: $0.61-.90 \mathrm{~m}$

Class 4: $0.91-1.20 \mathrm{~m}$

Class 5: $1.21 \mathrm{~m}-1.29 \mathrm{~m}$

The dot tally is recorded as follows:

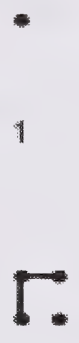

6

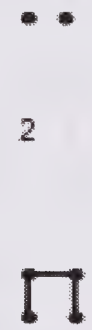

7

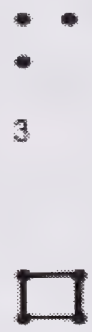

8

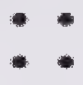

4

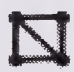

9

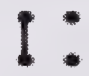

5

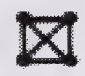

10

If regen are present of a species not listed on the tally sheet, such as PF or FA; record the species in the blank spaces in the species column at the bottom of the sheet. To assist in determining which height class a regen is in, the stick used to measure breast height should be marked at $0.10 \mathrm{~m}, 0.30 \mathrm{~m}, 0.60 \mathrm{~m}, 0.90 \mathrm{~m}$, and $1.20 \mathrm{~m}$.

Regen, as shown on the tally sheet are recorded as tree number 9998.

If there is no regen present in the plot, record "No Tally" diagonally across the green shaded area. On plots with 4 subplots a regen tally form must be completed for each subplot.

\subsubsection{Crown Width Measurement}

Started with year 2000 field season the crown width of a sample of trees/sapling/regen by species will have 4 crown widths measured. The crown width to the North, West, South and East of the selected tree/sapling/regen will be recorded in the comments section. The criteria for selecting trees/saplings/regen to have crown width measured by species is as follows for new trees/saplings/regen (previous measured trees/saplings/regen have already been selected).

a) If $<10$ trees/sapling/regen, select all new trees/saplings/regen for crown measurements. 
b) If $>10$ but $<=20$ trees /sapling/regen, select every second tree for crown measurements.

c) If $>20$ but $<=40$ trees /sapling/regen, select every fifth tree for crown measurements.

d) If $>40$ but $<=100$ trees/sapling/regen, select every eight tree for crown measurements.

e) If $>100$ trees /sapling/regen, select every tenth tree for crown measurements.

This measurement is to be taken in the 4 cardinal point directions and is measured from the stem out. A reading of 2.5 metres is to be recorded as 25 (decimeters). This measurement is not to be done on dead trees/saplings/regen. If a tree has died that has been selected to have it crown measured, do not measure dead branches. Select the next tree of the same species as the new crown width tree and record the 4 measurements on the tally sheets. Do not select dying or leaning trees as a new crown width tree. See Figure 2.8.

The crown measurement is estimated at the widest portion (half of crown diameter for that cardinal direction of the foliage looking up from the base of the tree. For deformed or leaning trees/saplings regen do not use due to difficulty in properly calculating crown width. Chose another tree of the same species.

\subsubsection{Plot Photography}

Colour photographs of each plot are taken once the measurements are completed. These photographs serve as a method of visual documentation of the overstorey and understorey for the plot and cover type. Numbered cards should be used in the photographs to identify the plot. Two photographs are taken from the group plot center in 4 subplotters and plot center of one subplotters; one facing east and the other facing west, with the photographer standing at back from plot center so that the flagged center post is in the photograph. Record picture frame numbers on checklist for subplot \#1.

\subsubsection{Vegetation and Soils}

The Public Lands and Forests Division is interested in correlating PSP data with information regarding site, vegetation and soils. For this reason information and samples are being collected.

\subsubsection{Vegetation Sampling}

Vegetation plots shall be circular with an area of $400 \mathrm{~m}^{2}$ (radius $11.25 \mathrm{~m}$ ) and central around the group centre (pre-1981) or plot centre (post - 1981). Methods of vegetation identification are outlined in Land Information Branch manual "Site Description".

\subsubsection{Soil Sampling}

In plots established before April 1981, the soil sample pit is located as close to group centre as possible without disturbing the vegetation plot. 
For plots established after 1981, the pit is located within the buffer as close to the tagged trees as possible. $\mathrm{Be}$ careful not to disturb the roots of the tagged trees.

Methods for determining soil type, texture, etc. shall be done as outlined in the Canadian System of Soil Classification. Collected data is recorded on the "Soil Description Form".

\subsection{PLOT REMEASUREMENT PROCEDURES}

Plots are remeasured according to the time schedule presented in Section 1.1. It is essential that the remeasurement is done accurately as the incremental growth for a particular time frame is necessary for growth and yield calculations. Section 2.1, Plot Establishment, should be read first as it explains the methodology for measurements in this section.

\subsubsection{Plot Layout}

Permanent sample plots established prior to April 1981 have a different plot layout format and a variety of plot sizes. Each of these PSP's (group) contains four separate plots (see Figure 2.9) with a reservation boundary surrounding the entire group.

The distance from the group centre to the nearest corner of each plot is either $20.1 \mathrm{~m}$ or $50.3 \mathrm{~m}$. With this design the buffer is $100 \mathrm{~m}$ or $150 \mathrm{~m}$ from the group centre in any cardinal direction.

The size of a plot varies in order to obtain a minimum of 100 living trees per plot. All plots in each group have the same plot size with sapling plot $1 / 4$ the size of the tree plot and the regeneration plot $1 / 16$ the size of the tree plot. The various tree plot sizes, along with the corresponding sapling/regeneration plot sized are listed on the next page. Post 1981 plot size was changed to $1 / 16$ of plot for both saplings/regen plots.

\section{Pre April 1981 Plot Layout}

\begin{tabular}{|l|l|l|l|l|l|}
\hline \multicolumn{3}{|c|}{ Tree Plot } & \multicolumn{2}{c|}{ Sapling/Regen Plot } \\
\hline $\begin{array}{l}\text { Area } \\
(\mathrm{ac})\end{array}$ & $\begin{array}{l}\text { Area } \\
\left(\mathrm{m}^{2}\right)\end{array}$ & $\begin{array}{l}\text { Side } \\
(\mathrm{m})\end{array}$ & $\begin{array}{l}\text { Diagonal } \\
(\mathrm{m})\end{array}$ & $\begin{array}{l}\text { Plot Area } \\
\left(\mathrm{m}^{2}\right)\end{array}$ & $\begin{array}{l}\text { Side } \\
(\mathrm{m})\end{array}$ \\
\hline $1 / 20$ & 202 & 14.23 & 20.12 & 13 & 3.56 \\
\hline $1 / 10$ & 405 & 20.12 & 28.45 & 25 & 5.03 \\
\hline
\end{tabular}




\begin{tabular}{|l|l|l|l|l|l|}
\hline $1 / 8$ & 506 & 22.49 & 31.80 & 32 & 5.62 \\
\hline $1 / 5$ & 809 & 28.45 & 40.23 & 50 & 7.11 \\
\hline $1 / 4$ & 1012 & 31.81 & 44.98 & 63 & 7.95 \\
\hline $1 / 4$ & 2023 & 44.98 & 63.61 & 127 & 11.25 \\
\hline
\end{tabular}

Note: All distances are horizontal distances

Prior to 1981, all PSPs were established using the above metric measures. PSPs established since 1981 used plot sized given in Section 2.1.2. ie. tree plot of $1 / 10$ hectare. All distances are horizontal distances.

\subsubsection{Plot Maintenance}

The following items are checked:

1. Evaluate the access (see Appendix 4.7)

2. GPS the reservation boundary (buffer) and repaint/tag it blue. All buffer trees should have a rectangle $(22 \mathrm{~cm} \times 28 \mathrm{~cm})$ painted, (1/3 of the circumference on each tree), at eye level (2m above ground) facing away from plot. The trees used for buffer corners should be painted/tagged on two sides facing out from the plot and have " $\mathrm{C}$ " painted on them to indicate a buffer corner and the bearing designation (i.e. NW, SE, etc.) In the event that plot has two blue buffers painted, the incorrect one must be covered with black paint and noted on the maintenance report.

3. Check the condition and tags of all the posts, centre and corners. Replace and retag where necessary.

4. Replace any tree tags and nails if necessary (for example if $<2 \mathrm{~cm}$ of nail is protruding out). Do not worry about missing tags at this time.

5. Rate the overall condition of the plot and buffer, noting any damages and their location on the plot maintenance sheet (Figure 2.10).

6. Measure all Saplings/Regen and tree plot sides. Record sizes on maintenance tally sheet. These only have to be remeasured if posts/pins have been disturbed since previous measurements. Reproduce map using previous sizes if okay.

7. The tie-point for each plot must be confirmed. This includes checking the distance and azimuth from the plot centre to the tie-point. Keep in mind the distances are horizontal and must be adjusted for slopes exceeding $10 \%$. Whenever possible, a second-tie-point should be established in the event that the original tie-point is destroyed. Suitable tie-points include definite bends in roads, stream crossing such as bridges and culverts or any other permanent land features. A topofil or survey chain must be used to measure the distance between tie points. A vehicle odometer is not accurate by our 
standards therefore it is not acceptable for measuring distance. The tie-point must be easily located on a forest cover type map.

8. Ensure North arrow is correctly located on maintenance tally sheet.

9. If there is any type of seismic or logging damage to the buffer or tree plot that was not noted on the previous maintenance report, record details such as distance away from the tree plot, approximate number of trees cut if the tree plot was disturbed and approximate year of damage (needles still present coniferous trees is a good indicator that the plot was disturbed within the last year). Check with supervisor if plot should be closed. If the plot was damaged by seismic activity, look for aluminum tags nailed to a tree along the line. Record all data off the tag on the maintenance report. This will help in determining what company was responsible for the damage.

\subsubsection{Plot Assessment at Remeasurement}

Plot assessment at remeasurement is done using the same techniques given in Section 2.1.3.4

\subsubsection{Maintenance Report}

The information recorded on the maintenance report is also documented on the Header Sheet. Some of this information is subjective and requires good judgment as budget requirements, planning of field work and other office decisions are based on this information.

The PSP maintenance sheet (Figure 2.10) is located on the reverse side of the PSP Header Sheet, TM 267 (Figure 2.13). For PSP's established before April 1981 where there are four sub-plots the maintenance information should all be recorded on the maintenance sheet of sub-plot one.

The legal location of the group is confirmed once the tie-point information and associated map work is completed (see Appendix 8). A PSP group can conceivably occupy up to four sections and legal sections and legal subdivisions. In the comments section of the PSP Maintenance Sheet you must note the location of plot center. In addition, careful location of the plot on the map is necessary for reservation purposes and relocation for subsequent remeasurements.

Access is extremely important for planning purposes for both remeasurement and maintenance crews. Budget estimates rely heavily on the amount of time it takes to travel to a plot and what type of transportation is required (ie. 4-wheel drive vehicle, all terrain vehicle or helicopter). Access is assessed using the following codes (see Appendix 7).

$\begin{array}{ll}1 & \text { All weather road } \\ 2 & \text { Dry weather road } \\ 3 & \text { Deteriorating road } \\ 4 & \text { All terrain vehicles only } \\ 5 & \text { Helicopter access only } \\ 6 & \text { Unknown }\end{array}$


Alberta Vegetation Inventory Field (AVI) overstorey calls are determined using the AVI Standards Manual V2.1. This information is used as a field check of photo interpreted overstoreys.

Plot and buffer damage to the plot is assessed using the following codes:

$\begin{array}{ll}1 & \text { No Damage } \\ 2 & \text { Natural damage } \\ 3 & \text { Manmade damage } \\ 4 & \text { Natural and manmade damage } \\ 5 & \text { Closed }\end{array}$

Code 6 is used to indicate buffer damage only.

6 Damage inside buffer greater than $20 \mathrm{~m}$ from subplot

Code 7 is to be used by office staff only. Field crews ignore this code.

$7 \quad$ Plot was previously closed but has been reopened.

Figure 2.11 illustrates the buffer damage zones for both the large and small groups. The buffer damage zones surround each subplot by $20 \mathrm{~m}$ from any point on the tree plot boundary. Any disturbance inside a buffer damage zone will have the appropriate damage code recorded for that subplot only. If there is disturbance inside the buffer, that is further than $20 \mathrm{~m}$ from a subplot, code 6 is recorded. (See Figure 2.12 for examples).

On the PSP Maintenance Sheet, crews must draw in either 1-plot group or a 4-plot group in the space provided. Drawings must be clear and concise so that the information is not misinterpreted.

For those PSPs that contain four plots, the horizontal distance from the group center to the four nearest plot corners is measured. This will assist in re-establishment of the plots if the entire group is destroyed. The plot sides are measured and recorded for each tree plot. Corner posts for the tree plot may have to be reestablished using the appropriate distances (Section 2.2.1) if the previous location cannot be found. Sapling/regeneration plots must be located in establishment and remeasurement situations but is not required for general plot maintenance.

Length of sides of buffer are also recorded on maintenance sheet. Each plot has a checklist, which must be completed after the plot is completely finished (one for each subplot on 4-subplot PSP's)

\subsubsection{Plot Remeasurement}

Before proceeding with the plot remeasurement, obtain a copy of the previous plot measurements to prepare the PSP tally sheets. In the shaded columns, copy the species, DBH and height obtained from the last measurement for each tree number so that comparison can be made between measurements in the field. Previous tree measurements have caused conflicts in the data base are to be noted on the tally sheet and double checked in the field (see Section 2.6) 


\section{Field Program Note}

In 1998 an electronic field program was developed for data entry of tree measurement data. See instruction manual for how the program operates. A copy of previous measurement data should be kept on hand in a file folder in case of problems with field computer. Spare PSP tally sheets are available from crew leaders.

Plot maintenance tally sheet checklist, and regeneration tally sheets are still to be completed. Once plots has been remeasured, regeneration data has to be inputted into electronic field program. See instruction manual on program.

\subsubsection{Tree Remeasurement}

The size limits defining trees, saplings and regeneration remain the same as stated in the plot establishment procedure (see Section 2.1.4). In addition, all tagged trees that have died and are standing since the last measurement must have DBH measured. On a number of plots, established prior to 1981 and 700 type plots, stems have been tagged that have diameters less than $9.1 \mathrm{~cm}$ and were considered as trees. These stems are still to be measured and considered as trees (do not count as saplings if they fall in sapling/regen plot).

\subsubsection{Species Coding}

A species code (see Master Appendix 12) is recorded for all trees unless the tree is missing or cut down. By recording a species, the records for the previous measurement are confirmed. In the event that the species is not the same for a given tree, record the proper code and make a note in the comments section (eg. Tree 70 is a white spruce and write double checked $(\sqrt{ } \sqrt{ })$ species in comments section. Species is recorded for standing dead and dead and down trees.

\subsubsection{DBH Remeasurement}

All tagged stems are measured for diameter directly below the nail. In the event that tag is located below $1.05 \mathrm{~m}$ or above $1.55 \mathrm{~m}$ from the point of germination, the diameter is taken at the location; the measurement is recorded in the comment section and the tag is relocated to breast height. This new diameter is measured and recorded in the DBH column on the tally sheet.

In some plots, very small trees have had tags wired to them. Replace the wire with a nail, at breast height, if the tree is large enough to withstand a nail or wire with copper wire and tie tag to wire.

When it is evident that a tag will be grown over within 10 years, remove the nail and replace it with a new nail in the same location. Tags are to be replaced if the number is not legible.

Deciduous trees do not take nails well. Copper wire is used. Leave lots of slack in wire so that tree is not girdled by next measurement. Tie tag to copper wire.

If a tree has died and is still standing since the last measurement, measure and record the current diameter. Trees that are dead and down or standing dead in the previous measurement are not to be measured. Only 
condition codes 25 or 61 (see Master Condition Code List) are recorded for these situations. Can also add on $2^{\text {nd }}$ or $3^{\text {rd }}$ condition codes if necessary. A tree is determined as dead when there is no evidence of living leaves or buds. Tags are not to be removed but nailed in completely on these trees. Hold tag horizontally when pounding in nail.

In the event that two separate trees have grown together, continue to measure them as separate trees. If a diameter tape cannot be wrapped around the individual trees, use tree calipers and take an average of two measurements, taken perpendicular to each other, for each tree.

If there are two trees with the same number, one of the tags must be replaced and labeled with the number following the last tree number used in the previous measurement for that plot and noted in the comments section.

\subsubsection{Missing Trees}

The missing condition code (15) is used when a previously numbered tree cannot be found. When a specific tree cannot be found, check for trees without tags in the numbering sequence that are the same species and have a comparable diameter. If the tree is the one in question, retag the tree; otherwise it is considered ingrowth. In plots that have been stem mapped, the azimuth and distance information can be used to locate missing trees. Stem mapping, itself, often locates missing trees by checking that all trees, with condition codes other than 15 or 61 , have an azimuth and a distance. Do not record a species if the tree is missing.

\subsubsection{Ingrowth}

All untagged stems in the tree plot that now have a DBH $\geq 9.1 \mathrm{~cm}$ must be tagged, measured, and stem mapped. The tree numbers for these stems will start with the number following the last tree number in the previous measurement. The exception to this is 700 series plots, refer to Section 4.11.

\subsubsection{Completing the Tree Remeasurement}

Tree heights and heights to live crowns are measured using the procedure outlined in Section 2.1.4.4. Do not take heights on trees that were previous sample trees and have died since the last measurement. Crown classes are recorded as stated in Section 2.1.4.6 and condition codes (see Master Condition Code List) are applied to tagged trees and saplings. Stem mapping is done on remeasurement plots only if it has not been done in previous measurement. Ingrowth is stem mapped. Do not measure ages and increment widths unless directed to do so.

\subsubsection{Sapling and Regeneration Remeasurements}

The sapling/regen plot is measured in the same manner outlined in Section 2.1.5 


\subsubsection{Nails}

Nails should be pulled out as the trees grow. Maintain the $2.4-3.5 \mathrm{~cm}$ of nail extruding from the tree. Turn tag at $90^{\circ}$ from the tree and pound the nail in it tree standing is dead.

\subsubsection{Plot Photography}

Colour photographs are taken as directed in Section 2.1.6. For plots established prior to 1981, the photographs are taken at group center, with the photographer standing so that the flagged group plot center is in the photograph.

\subsection{PLOT CLOSURE}

PSP's are never closed. PSP's lost to Forest Fires have a regeneration type PSP established over top of the old one.

\subsubsection{Re-opened Plots}

If a plot was previously closed, every attempt to re-open it should be made. The plot should be checked for missing, dead, or cut-down trees. If the tags were removed, an attempt to locate or re-establish plot corners should be made. If plot corners cannot be re-established, a recommendation to cancel the plot shall be made to the Forester in charge and the reservation will be cancelled.

\subsection{DATA ENTRY ON HEADER AND TALLY SHEETS}

Measurements taken on permanent sample plots are recorded on Permanent Sample Plot Header Sheets (TM267), Permanent Sample Plot Tally Sheets (TM249) and on Regeneration Tally Sheets (TM261). Data recorded on the front of each tally sheet in the white columns is keypunched in the same format to keep the tally sheets and computer files compatible. It is important that all letters and numbers are legible to avoid keypunch errors resulting in costly computer errors. Quality measurements are of no value if they are not legible. See Appendix 14 for common problems.

\subsubsection{PSP Header and Tally Sheets}

The PSP Header Sheet is separated into a section of general information and is recorded as type: 01 (see Figure 2.13 - columns 36,37 ).

The PSP Tally Sheet is separated into one record type: 02 (see Figure 2.14 - columns 36,37 ). 


\subsubsection{General Information (columns 1-37)}

This information must be recorded on the Header Sheet and repeated in the green shaded area of every Tally Sheet. The following columns match the electronic database format.

\begin{tabular}{|c|l|l|}
\hline Column & \multicolumn{1}{|c|}{ Name } & \multicolumn{1}{c|}{ Data Entry } \\
\hline 1 & Agency & Right justified, zero filled. The agency list is in Appendix 4.10.1.1 \\
\hline 3 & Group Number & Right justified, zero filled eg. 20 is written as 020 (see Figure 2.13) \\
\hline 13 & Sub -Plot Number & $\begin{array}{l}\text { Numeric 1-4. Sub Plot number is always 1 for plots established since } \\
\text { April 1981. }\end{array}$ \\
\hline 14 & Measurement Number & $\begin{array}{l}\text { Numeric, zero filled 00 for establishment, subsequent measurements } \\
\text { are 01,02,03, etc. eg. 3rd remeasurement records as 03 }\end{array}$ \\
\hline 16 & Year & Recorded to 4 digits \\
\hline 20 & Month & Right justified, zero filled eg. June is recorded as 06 \\
\hline 22 & Day & $\begin{array}{l}\text { Right justified, zero filled. Note: Date is the same on all tally sheets } \\
\text { even if the sub plot took several days to measure }\end{array}$ \\
\hline 24 & L. S. (Legal Subdivision) & Right justified, zero filled -2 digits \\
\hline $26-27$ & Section & Right justified, zero filled -2 digits \\
\hline $28-30$ & Township & Right justified, zero filled - 3 digits \\
\hline $31-32$ & Range & Right justified, zero filled -2 digits \\
\hline 33 & Meridian & Right justified, zero filled \\
\hline 34 & Plot type & Left justified, zero filled, priorized. Where no codes are used, '000' fill. \\
\hline 37 & Imp & $\begin{array}{l}\text { An “ } x \text { " is written only if the data is collected in imperial units, blank if } \\
\text { collected in metric. }\end{array}$ \\
\hline
\end{tabular}

\subsubsection{Record Type 01 - Header Information (Columns 38 - 212)}

This information is filled out on the Header Sheet of each plot.

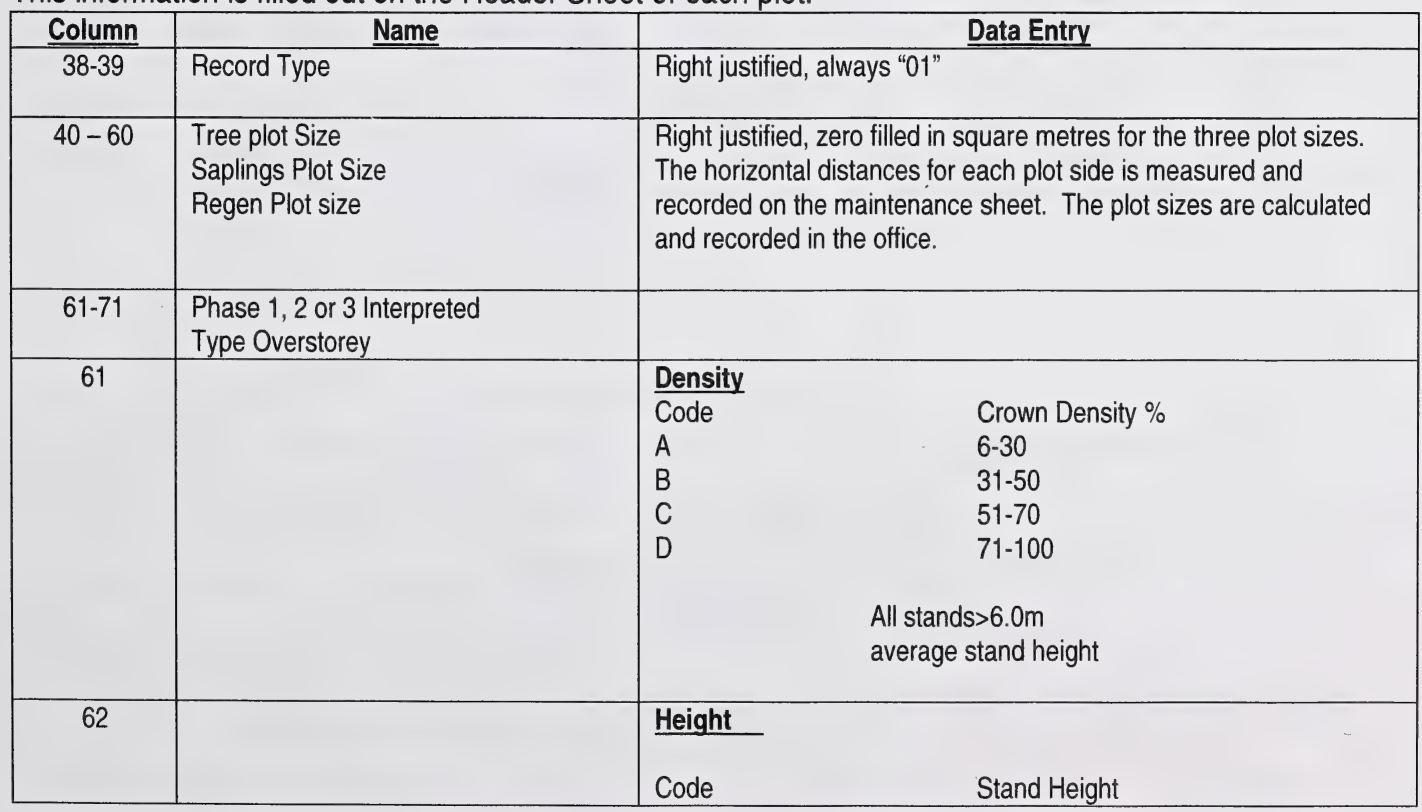

Page 21 


\begin{tabular}{|c|c|c|}
\hline & & $\begin{array}{lr}0 & 0-6.0 \mathrm{~m} \\
1 & 6.1-12.0 \mathrm{~m} \\
2 & 12.1-18.0 \mathrm{~m} \\
3 & 18.1-24.0 \mathrm{~m} \\
4 & 24.1-300 . \mathrm{m} \\
5 & >30 . \mathrm{m}\end{array}$ \\
\hline \multirow[t]{5}{*}{$63-70$} & & $\begin{array}{l}\text { Species composition is listed as a percent of the gross roundwood } \\
\text { (13/7) ( } 13 \mathrm{~cm} \text { stump, } 7 \mathrm{~cm} \text { top) volume for stands over } 12 \mathrm{~m} \text { in } \\
\text { height. For stands under } 12 \mathrm{~m} \text { in height the crown cover is used for } \\
\text { species composition. }\end{array}$ \\
\hline & & $\begin{array}{l}\text { Species is recorded in order of decreasing content up to a maximum } \\
\text { of three species above } 20 \% \text { (major). Species } 11-20 \% \text { are recorded } \\
\text { in brackets (minor) and species } 10 \% \text { or less are not recorded. }\end{array}$ \\
\hline & & $\begin{array}{l}\text { An understorey is recognized only when it is two or more height } \\
\text { classes lower than the overstorey. }\end{array}$ \\
\hline & & $\begin{array}{l}\text { An example of a field overstorey and a field understorey type is: } \\
\text { B3AW (PL) and A1SW. Note: These columns are only completed at } \\
\text { establishment by offices staff. }\end{array}$ \\
\hline & & Left justified \\
\hline 71 & & Overstorey Stand Commercialism \\
\hline $72-93$ & AVI Interpreted Type Overstorey & See 4.10.1.2 for methodology \\
\hline $94-108$ & $\begin{array}{l}\text { Phase } 1,2 \text { or } 3 \text { Interpreted Type } \\
\text { Understorey }\end{array}$ & \\
\hline 94 & & $\begin{array}{l}\text { Crown Density \% } \\
6-30 \\
31-50 \\
51-70 \\
71-100 \\
\text { All stands }>6.0 \text { m average stand } \\
\text { height }\end{array}$ \\
\hline 95 & & $\begin{array}{l}\frac{\text { Height }}{\text { Code }} \\
0 \\
1 \\
2 \\
3 \\
4 \\
5 \\
\end{array}$ \\
\hline & & $\begin{array}{l}\text { Species composition is listed as a percent of the gross roundwood } \\
\text { (13/7) ( } 13 \mathrm{~cm} \text { stump, } 7 \mathrm{~cm} \text { top) volume for stands over } 12 \mathrm{~m} \text { height. } \\
\text { For stands under } 12 \mathrm{~m} \text { in height the crown cover is used for species } \\
\text { composition. }\end{array}$ \\
\hline & & $\begin{array}{l}\text { Species is recorded in order of decreasing content up to a maximum } \\
\text { of three species above } 20 \% \text { (major). Species } 11-20 \% \text { are recorded } \\
\text { on brackets (minor) and species 10\% or less are not recorded. }\end{array}$ \\
\hline $96-103$ & & $\begin{array}{l}\text { An understorey is recognized only when it is two or more height } \\
\text { classes lower than the overstorey }\end{array}$ \\
\hline
\end{tabular}

Page 22 


\begin{tabular}{|c|c|c|}
\hline & & $\begin{array}{l}\text { An example of a field overstorey and a filed understorey type is } \\
\text { B3AW (PL) and A1SW. Note: These columns are only completed at } \\
\text { establishment by office staff. }\end{array}$ \\
\hline & & Left justified. \\
\hline 104 & & Understorey Stand Commercialism \\
\hline $105-108$ & & Understorey Stand Origin \\
\hline $109-128$ & AVI Interpreted Type Understorey & See 4.10.1.2 for methodology \\
\hline 129 & Location & \\
\hline $130-132$ & Slope Percent & Right Justified \\
\hline 133-134 & Aspect & $N, W, N E$, etc. "NA" for No Slope \\
\hline $135-138$ & Elevation & Right justified \\
\hline 139 & Erosion Potential & \\
\hline 140 & Drainage & \\
\hline $141-142$ & Depth to Mineral Soil & Right Justified in cm. \\
\hline 143 & Surface Vegetation Type & \\
\hline $144-146$ & Ground Cover Percent & Right Justified \\
\hline 147 & Access & \\
\hline 148 & Plot Damage & \\
\hline 149 & Buffer Damage & \\
\hline 150-153 & Establishment Year & \\
\hline $162-163$ & Plot Type & $\begin{array}{l}\text { Usually=1 may have other management practices done on plot later } \\
\text { and will have to be changed. }\end{array}$ \\
\hline 164 & Plot configuration & Always - 1 \\
\hline 180-183 & Stand Origin & \\
\hline 184 & Site Index/TPR & Character \\
\hline $185-186$ & Site Index/TPR & Numeric \\
\hline $187-190$ & Photo Year & \\
\hline 191-193 & Stand Structure & \\
\hline 194-198 & Ecosite & \\
\hline 199-201 & Aspect in degrees & Right Justified \\
\hline 202 & Nutrient Regime & \\
\hline $203-204$ & Natural Subregion & Right Justified \\
\hline $205-208$ & Minimum Diameter Measured (mm) & Right Justified \\
\hline $209-210$ & Stump Height $(\mathrm{cm})$ & Right Justified \\
\hline 211 & Surface Expression & \\
\hline 212 & Slope Position & \\
\hline
\end{tabular}

\subsubsection{RECORD TYPE 02 (COLUMN 38-124)}

Header information columns 1 to 37 are repeated on each record.

\begin{tabular}{|c|l|l|}
\hline COLUMN & \multicolumn{1}{|c|}{ NAME } & \multicolumn{1}{c|}{ DATA ENTRY } \\
\hline $38-39$ & Record Type & Right Justified, always "02" \\
\hline $40-43$ & Tree Number & Right Justified, numeric, either: \\
& & -consecutive $1->9997$ (tagged trees/saplings) \\
& & -0000 (felled trees outside plot) \\
& $-($ number prefilled on Header Tally Sheet) \\
& & Filled in prior to remeasuring with the previous measurements to \\
& & \\
& & \\
& & \\
\end{tabular}




\begin{tabular}{|c|c|c|}
\hline & $\begin{array}{l}\text { Darkened columns - Species, } \\
\text { DBH, Height }\end{array}$ & \\
\hline $44-45$ & Species & Recorded as two capitalized letters as given in Section 2.1.4.1 \\
\hline $46-49$ & $\mathrm{DBH}$ & Right Justified to one decimal point. \\
\hline $50-53$ & Height & Right justified to one decimal point. \\
\hline $54-57$ & Height to Live Crown & Right justified to one decimal point. \\
\hline 58 & C.C. & $\begin{array}{l}\text { Crown class is recorded as one letter }(\mathrm{D}, \mathrm{C}, \mathrm{I}, \mathrm{S}, \text { or } 0) \text { as per section } \\
\text { 2.1.4.6 }\end{array}$ \\
\hline $59-64$ & Condition codes & $\begin{array}{l}\text { Left justified, recorded as a } 2 \text { digit number, as per Section 2.1.4.7, but } \\
\text { do not zero fill eg. a leaning tree with conks is recorded as } 5851 \\
\text { blank, blank. If a tree has no defect, it is recorded as ' } 00 \text { '. }\end{array}$ \\
\hline $65-67$ & DBH Age & Right justified, recorded only for tree numbers 0000. \\
\hline $68-70$ & Stump age & Right justified, recorded only for tree numbers 0000 . \\
\hline $71-73$ & $\begin{array}{l}\text { Stump Increment Width-Previous } \\
10 \text { Years }\end{array}$ & $\begin{array}{l}\text { Measured as indicated in Figure 2.7. Recorded to one decimal place } \\
\text { in centimeters. Zero filled, eg } 23 \mathrm{~mm} \text { is recorded as } 02.3 \text {. In digital } \\
\text { file entered as mm. }\end{array}$ \\
\hline $74-76$ & $\begin{array}{l}\text { Stump Increment Width-Previous } \\
11-20 \text { years }\end{array}$ & In digital file, entered as $\mathrm{mm}$. \\
\hline $77-79$ & Azimuth & Right Justified, recorded as $1^{\circ}-360^{\circ}$. \\
\hline $80-82$ & Distance & Right justified to one decimal point. \\
\hline $83-89$ & Tree Plot Size $\left(\mathrm{m}^{2}\right)$ & Right justified \\
\hline $90-96$ & Sapling Plot Size $\left(\mathrm{m}^{2}\right)$ & Right justified \\
\hline $97-103$ & Regen Plot size $\left(\mathrm{m}^{2}\right)$ & Right justified \\
\hline 104-107 & Establishment Year & Right justified \\
\hline 108 & Crown Status & $\begin{array}{l}\text { "Y" indicates tree needs crown measurements } \\
\text { "Blank" indicates no crown measurement required. }\end{array}$ \\
\hline $109-112$ & Crown Width North & Recorded in decimeters (dm). Right Justified \\
\hline $113-116$ & Crown Width West & Recorded in decimeters (dm). Right justified \\
\hline $117-120$ & Crown Width South & Recorded in decimeters (dm). Right justified. \\
\hline $121-124$ & Crown Width East & Recorded in decimeters (dm). Right justified. \\
\hline
\end{tabular}

\subsubsection{Other Data}

Information that is shaded in green and to the right of record type 01 on the Header Sheet is not keypunched. It is, however, required that this data be recorded: crew, page number including the regen tally sheet (eg. 1 of 10), photo and line number, and tie point. Space is also provided at the bottom of the page of the Header Sheet or any comments the crew would like to record.

On the Tally Sheet, comments may be entered in the darkened columns to the right of the record type 02 . For example, tree \# 243 is near tree \#100.

Height measurements are recorded and calculated on the back of the tally sheet.

An increase in buffer size must be noted in the comments section. 


\subsubsection{Regeneration Tally Sheet}

The regeneration tally sheet is separated into general information and record type 03 (see Section 2.4.2.2 columns 38,39).

\subsubsection{General Information (Columns 1-37)}

This area is shaded in green but is still the same format, as described in Section 2.4.1.1 with the same data as recorded on the PSP Header Sheet.

Header information 1 to 37 is repeated on each record.

\subsubsection{Record Type 03 (Columns 38-85)}

\begin{tabular}{|l|l|l|}
\hline \multicolumn{1}{|c|}{ COLUMN } & \multicolumn{1}{|c|}{ NAME } & \multicolumn{1}{c|}{ DATA ENTRY } \\
\hline $38-39$ & Record Type & Right Justified, always "03" \\
\hline $40-43$ & Tree Number & Pre-entered, is always 9998 for regeneration \\
\hline $44-45$ & Species & $\begin{array}{l}\text { Recorded in the blank column at the bottom of the } \\
\text { sheet, as two capitalized letters as per Section 2.1.4.1, } \\
\text { if the species presents is not already listed. }\end{array}$ \\
\hline $\begin{array}{l}\text { Darkened columns - } \\
55-57,58-60\end{array}$ & Height Class 1-5 & $\begin{array}{l}\text { Used to record the dot tally, This area is not } \\
\text { keypunched. Right justified, zero filled, numeric. }\end{array}$ \\
\hline $61-67$ & Total (1-5) & Right justified \\
\hline $68-74$ & Tree Plot Size $\left(\mathrm{m}^{2}\right)$ & Right justified \\
\hline $75-81$ & Sapling Plot Size $\left.\mathrm{m}^{2}\right)$ & Right justified \\
\hline $81-85$ & Regen Plot Size $\left(\mathrm{m}^{2}\right)$ & Right justified \\
\hline
\end{tabular}

\subsection{VEGETATION AND SOILS}

Vegetation and soil data are collected at remeasurement only if it has not been done at establishment or if directed to do so by office staff.

\subsection{DOUBLE CHECKING TALLY SHEETS}

Before leaving the PSP, crews will double check for shrinking or non-growth DBHs, height and species changes. Place a double check mark in the comments section to note that the correct information was tallied. 


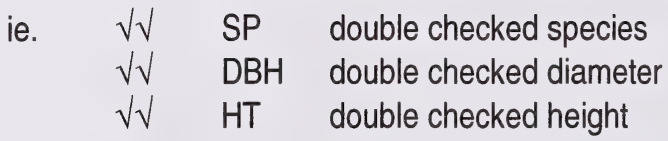

Before handling in tally sheets to the supervisor for keypunching, please double check that the following information is recorded correctly on the Header and Tally Sheets:

1. Write clearly and concisely. Keypunchers do not know what codes mean and cannot interpret sloppy writing.

2. Erase all extra marks in the white area of tally sheets, or they will be keypunched, ie. checkmarks in the azimuth columns.

3. Check again for any species changes and for shrinking DBHs and heights

4. There should be no crown classes for dead and down, cutdown, standing dead, missing broken top, broken stem and severe leaning trees $\left(>45^{\circ}\right)$

5. Crown classes are recorded for dead tops and die back (code 16).

6. Make sure heights have been correctly calculated and copied properly from the back to front of tally sheets

7. Make sure all header information is the same throughout group.

8. Trees that are coded as missing (15) or cutdown (29) should not have a species.

9. All pages are in place and in order

10. If using a direct read suunto, make sure it is mentioned on the Tree Height Calculation sheet and the appropriate columns are relabeled.

11. Code 25 \& 61 trees need the species recorded in column $42-43$

\subsection{PLOT CHECK}

Plot checks are done to ensure that the standards or measurement for permanent sample plots are being met. These standards are designed to minimize non-sampling errors that occur in all sampling. The standards given here are for the maximum error allowed before the plot must be redone. Plot checks should be viewed as a method of assessing the performance of field crews with the intent of identifying the human errors that can occur due to a lack of care or knowledge in field procedures.

\subsection{Inspection Procedures}

PSP and regeneration tally sheets should be checked in the field office to ensure that all the appropriate columns have been filled (eg. plot size, species, DBH, C.C. etc.). The heights are recalculated using the data recorded on the back of the PSP tally sheet. Plots that lack certain data or where the data appears incorrect should be selected for a check.

Plots should be field inspected when a new crew first begins establishment or remeasurement in order to monitor training needs and to identify and correct recording errors. 
The following technique is used to check plots:

1. Using a PSP Tree Tally Check Sheet (Rev. 4/87) (TM 249) (Figure 3.1) record the group and subplot number, photo information, date of check cruise, check cruise page number, names of initial field crew, and the names of the check crew for each of the plots selected for checking. Before proceeding to the field, record the data from the original tally sheets, for approximately $10 \%$ of the tagged trees including the tree number, DBH, crown class, condition codes, and azimuth and distance (when recorded) on the sheet. In addition, $10 \%$ of the measured and height to live crown measurements should be checked.

2. The selected trees are measured and tallied directly below the copied data measured by the field crew. The two measurements are compared and should be within the allowable error limits (see Section 3.2). On the Check Cruise Tally Sheet, only measurements not within the allowable error shall be "blocked in" red. If the two measurement are not within the allowable error limits, always assume the check cruise is correct. Transfer the Check Cruise Height that is "blocked in red" to the tree height calculation sheet (back of PSP Tally Sheet TM 249) as well as changing the appropriate information on the front of the tally sheets. If measurement errors are common, additional trees may be checked. Other tree plot items that may be checked include buffer painting, recorded elevations, tag replacement, etc. Data pertaining to plot establishment, plot assessment, and stem analysis (when recorded) are also checked.

3. It is important to show the field crew the original tally sheets and the check crew sheets in order to point out any discrepancies. Any problems with the plot measurements should be discussed in order to prevent future errors.

4. When the check cruise has been completed, the overall evaluation of the PSP is graded as excellent, very good, satisfactory, fair, or unsatisfactory. The following is a guide used to evaluate the plot.

- Excellent - no mistakes have been found in the check cruise

- Very good - an occasional, minor error has been found in the check cruise

- Satisfactory - a few errors have been found but their severity is minimal

- Fair - errors are frequent and of a greater severity. Additional field work is required to correct the major mistakes

- Unsatisfactory - errors are common and judged to be severe. Field work is required as the errors constitute an unacceptable plot and must be redone

Plots that have a grade of satisfactory or above can have any necessary corrections made on the tally sheets. The tally sheets are then submitted for keypunching.

\subsection{Allowable Errors}

The following is a guideline used to judge the correctness of each measurement type or required duty. 


\subsubsection{Plot Establishment}

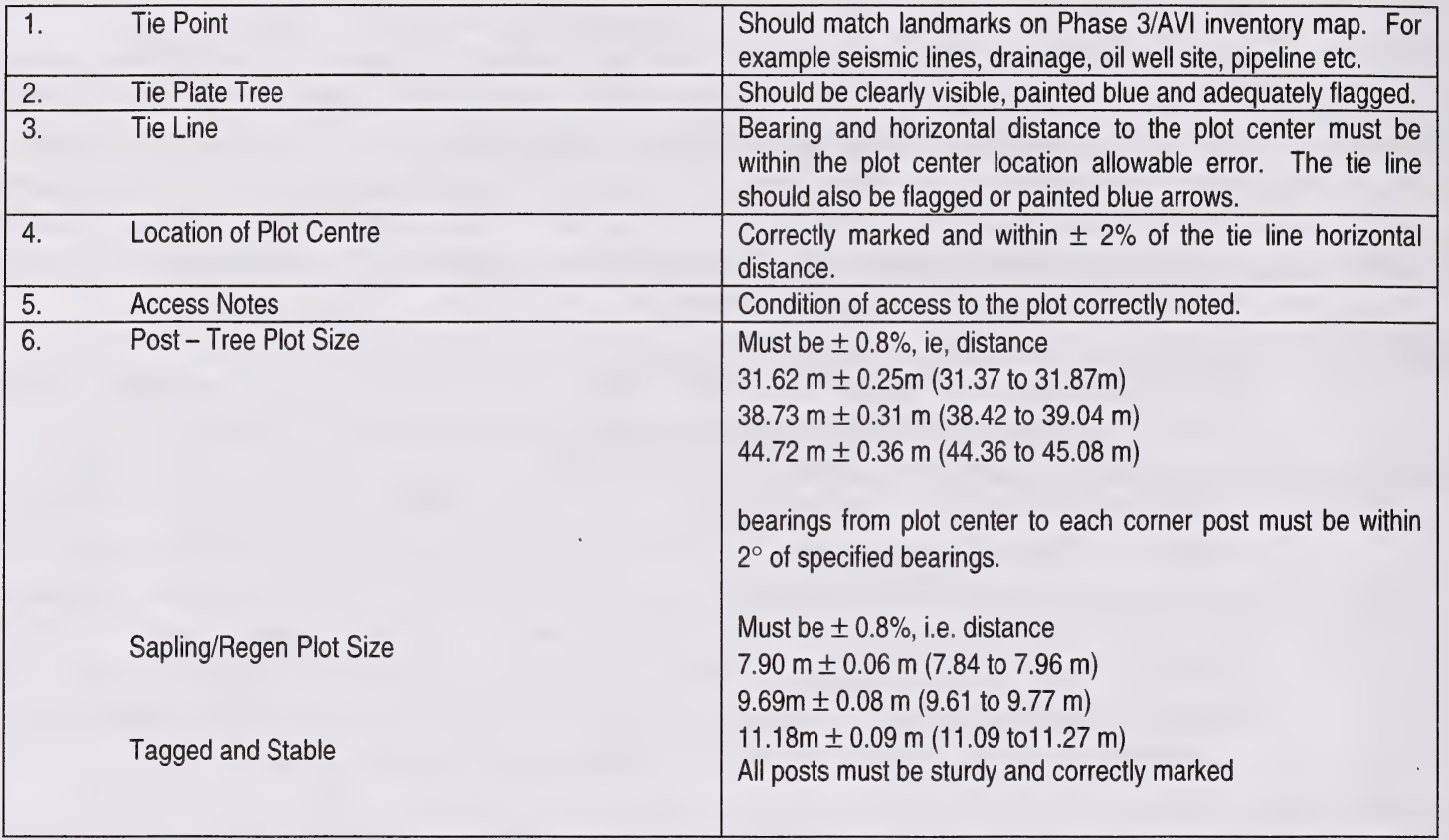

\subsubsection{Plot assessment}

Office staff are responsible for correctly recording all plot sized in square metres. The field overstorey and understorey (where appropriate) must be correctly identified using Phase 3/AVI specifications. Plot topography, soils, surface vegetation and the maintenance report must be reasonably estimated.

\subsubsection{Tree and plot measurement}

\begin{tabular}{|l|l|l|}
\hline 1. No. of Trees Tallied & Tree Plot & $\begin{array}{l}\text { No allowable error. All Tress identified, as within or } \\
\text { outside the plot must be correct. }\end{array}$ \\
\hline & Sapling Plot & $\begin{array}{l}\text { The allowable error is } \pm 5 \% \text { of the total number of } \\
\text { saplings tallied. }\end{array}$ \\
\hline & Regen Plot & $\begin{array}{l}\text { The allowable error is } \pm 10 \% \text { of the total number of regen } \\
\text { tallied. }\end{array}$ \\
\hline 2. Species Identified & Tree Plot & No Allowable error \\
\hline & Sapling Plot & No allowable error \\
\hline 3. DBH & Regen Plot & $\begin{array}{l}5 \% \text { of the total number of regen tallied may incorrectly } \\
\text { identified. }\end{array}$ \\
\hline & $\begin{array}{l}\text { Breast height should be correctly located at } 1.3 \mathrm{~m} \pm \\
6.5 \mathrm{~cm} \text { from the point of germination. The allowable error } \\
\text { for the tree DBH } \pm 1.0 \mathrm{~cm} .\end{array}$ \\
\hline
\end{tabular}




\begin{tabular}{|l|l|l|}
\hline $\begin{array}{l}\text { 4. Height and Height to Live } \\
\text { Crown }\end{array}$ & $\begin{array}{l}\text { The allowable is } \pm 3 \% \text { with discretion used for the } \\
\text { identification of where the live crown begins. }\end{array}$ \\
\hline $\begin{array}{l}\text { 5. Crown Class and Condition } \\
\text { Codes }\end{array}$ & $\begin{array}{l}\text { Only } 5 \% \text { of the stems tallied may have an incorrect crown } \\
\text { class or condition code. }\end{array}$ \\
\hline 6. Stem Mapping & $\begin{array}{l}\text { The allowable error for azimuth is } \pm 2^{\circ} \text { and for distance } \\
\text { is } \pm 0.5 \mathrm{~m}\end{array}$ \\
\hline
\end{tabular}

\subsubsection{Stem analysis}

\begin{tabular}{|l|l|l|}
\hline 1. Section Lengths & $\begin{array}{l}\text { The allowable error is } \pm 5 \mathrm{~cm} \text { from the proper length after } \\
\text { the "cookie" is cut. }\end{array}$ \\
\hline 2. Perpendicular Cuts & $\begin{array}{l}\text { The allowable error is } \pm 10^{\circ} \text { from the perpendicular for } \\
\text { cutting "cookies". }\end{array}$ \\
\hline 3. Ages & $\begin{array}{l} \pm 1 \text { year for coniferous trees, } \pm 5 \text { years for deciduous } \\
\text { trees }\end{array}$ \\
\hline
\end{tabular}

\subsubsection{Check cruising standards}

The check cruiser will usually check a minimum of $10 \%$ of the stems within a plot. More than $10 \%$ may be checked at the check cruisers discretion. Stem analysis tree are to be checked individually and are excluded from the minimum $10 \%$ within the tagged tree plot.

\begin{tabular}{|ll|l|}
\hline 1. & Diameters & $\begin{array}{l}\text { If more than } 3 \% \text { of the total tagged trees checked (within the plot) are not within the } 1.0 \mathrm{~cm} \\
\text { error range the entire plot/subplot will have the diameters remeasured this includes dead } \\
\text { trees). Included in this are tags that are not readable, nails not put in at a slight downward } \\
\text { angle, mislabeled tags (ie. numbers, written horizontally, not vertically), nails too deep or too } \\
\text { loose. }\end{array}$ \\
\hline 2. & Heights & $\begin{array}{l}\text { If more than } 20 \% \text { of those heights checked are out, the cruisers heights for that plot/subplot } \\
\text { will be rejected. }\end{array}$ \\
\hline 3. & $\begin{array}{l}\text { Condition } \\
\text { Codes }\end{array}$ & $\begin{array}{l}\text { If more than } 5 \% \text { of the condition codes checked are missed or incorrect, the condition codes } \\
\text { for that plot shall be re-done. A "missed" code will count as an error. }\end{array}$ \\
\hline 4. & Crown Class & $\begin{array}{l}\text { If more than } 5 \% \text { of the crown classes checked are incorrect, all the crown classes for that plot } \\
\text { will be re-done. }\end{array}$ \\
\hline 5. & $\begin{array}{l}\text { Stem more than } 5 \% \text { of the combined check of azimuths and distances are incorrect, stem } \\
\text { mapping will have to be re-done. }\end{array}$ \\
\hline 6. & Gapping & $\begin{array}{l}\text { Tie points and corner posts shall be marked with orange and blue geo-flagging tape. Tie } \\
\text { lines will be marked in } 20 \text { m intervals with orange flagging tape. }\end{array}$ \\
\hline 7. & Flagging Colour & $\begin{array}{l}\text { Orange - height trees/regen pins/tie line; } \\
\text { Orange and blue - plot/subplot corners; } \\
\text { Orange blue \& yellow - group center; } \\
\text { Yellow - problem trees, swaths, boundaries. }\end{array}$ \\
\hline
\end{tabular}




\section{References for Condition Code Assessments for Wildlife}

Conner, R.N. 1979. Seasonal changes in woodpecker foraging methods: strategies for winter survival. In: Dickson, J.G., Conner, R.N., Fleet, R.R., Jackson, J.A. and J.C.Kroll (eds), The role of Insectivorous Birds in Forest Ecosystems, Academic Press. New York. pp-95105.

Harrison, H. 1979. Western Birds Nests. Peterson field Guide Series. 280 pp.

Haritsuka, Y. 1987. Forest Tree Diseases of the Prairies Provinces. Information Report NOR-X- 286.

Murie, O.J. 1975. A Field Guide to Animal Tracks. Houghton Mifflin. 375 pp.

Rangen, S.A. and L.D. Roy. 1997.

A Field Guide to Animal Damage of Alberta's Native Trees. Alberta Research Council. Vegreville, Alberta. ARCV97-R1. 58 pp.

Sousa, P.J. 1987. Habitat Suitability Models: Hairy Woodpecker. Biological Report 82(10.146). U.S. Department of the Interior. Fish and Wildlife Service. 19 pp. 
. 


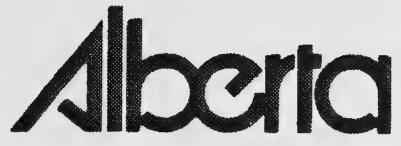

SUSTAINABLE RESOURCE

DEVELOPMENT

\section{PSP MANUALS MASTER CONDITION CODE LIST}

\section{MARCH 2005}

Public Lands and Forests Division

Forest Management Branch

$8^{\text {th }}$ Floor, $9920-108$ Street

Edmonton, $\mathrm{AB}$

T5K 2M4

Phone: (780) 427 - 8474

Or visit the website: http://www3.gov.ab.ca/srd/forests/psp 


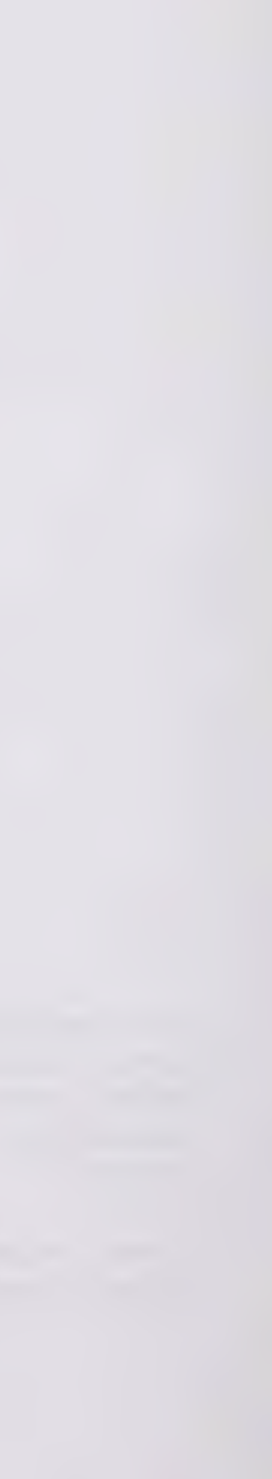


CONDITION CODES

\begin{tabular}{|c|c|c|c|}
\hline CODE & DESCRIPTIONS & CODE & DESCRIPTIONS \\
\hline 00 & Healthy & 47 & Witche's Broom \\
\hline 01 & Insects & 48 & Frost Crack \\
\hline 02 & Disease & 49 & Dying \\
\hline 03 & Rabbit Browsing & 51 & Conks/Blind Conks \\
\hline 04 & Shepherd's Crook & 52 & Open Scars \\
\hline 05 & Browsing (Other animal) & 53 & Burls and Galls \\
\hline 06 & Fire & 54 & Fork \\
\hline 07 & Mechanical & 55 & Pronounced Crook \\
\hline 08 & Windthrow & 56 & Broken Top (DBH > 9.1) (No CC) (see "24" for DBH <9.1) \\
\hline 09 & Climate & 57 & Limby \\
\hline 10 & Flooding & 58 & Severe Lean (No CC) - see code \#35 \\
\hline 11 & Poor Planting & 59 & Broken Stem $(>=10 \mathrm{~cm}$ DIB at Break DBH $>9.1$ ) (No CC) \\
\hline 12 & Suppression & 60 & Generic woodpecker feeding (often smaller species) \\
\hline 13 & Frost Heaving & 61 & Dead and Down (No CC) \\
\hline 14 & Erosion & 62 & Stem Insects (Bark + Sawyer Beetles) \\
\hline 15 & Missing & 63 & Stem Disease (Cankers) \\
\hline 16 & Dead Top/Dieback & 64 & Foliar Insects \\
\hline 17 & Poor Seedbed & 65 & Foliar Disease (Needle blights + rusts) \\
\hline 18 & Herbicide & 66 & $\begin{array}{l}\text { Stem Form Defect ( }>=7.0 \mathrm{~cm} \text { DIB at point where stem } \\
\text { form begins) }\end{array}$ \\
\hline 19 & Western Gall Rust (only on Pine) & 67 & Closed Scars \\
\hline 20 & Armillaria Root Rot & 68 & Atropellis canker \\
\hline 21 & Moldy Planting Stock & 69 & Comandra Blister Rust \\
\hline 22 & Multiple Leader & 70 & Elytroderma needle cast of pine \\
\hline 23 & Poor Form & 71 & Hypoxylon Canker \\
\hline 24 & $\begin{array}{l}\text { Broken Top (DBH <9.1) (see " } 56 \text { " } \\
\text { for DBH >9.1) }\end{array}$ & 72 & Spruce cone Rust \\
\hline 25 & Dead Tree Standing (No CC) & 73 & Stalactiform Blister Rust \\
\hline 26 & Snow Press (No CC) & 74 & Tomentosus Root Rot \\
\hline 27 & $\begin{array}{l}\text { Dead Top Dieback with NEW } \\
\text { Leader }\end{array}$ & 75 & Spruce Spanworm \\
\hline 28 & Sucker(s) (from OLD Stump) & 76 & Spruce Cone Maggot \\
\hline 29 & Cut down & 77 & Spruce Cone worm \\
\hline 30 & Terminal Weevil & 78 & Eastern Spruce Budworm \\
\hline 31 & SW Gall Adeigid & 79 & Mountain Pine Beetle \\
\hline 32 & Tent Caterpillar & 80 & Spruce Beetle \\
\hline 33 & Root Collar Weevil & 81 & Spruce Needle Rust \\
\hline 34 & J-Root & 82 & Yellow Headed Spruce Sawfly \\
\hline 35 & Leaning (No CC) - see code \# 58 & 83 & Large Aspen Tortrix \\
\hline 36 & Same Stump & 84 & Excavations by woodpeckers \\
\hline 37 & Unknown & 85 & Yellow-bellied sapsucker feeding \\
\hline 38 & Pitch Moth & 86 & Small mammal feeding on tree bole \\
\hline 39 & DBH Taken on New Leader & 87 & Small Cavity \\
\hline 40 & Nutrient Deficiency & 88 & Large Cavity \\
\hline 41 & Mouse (feeding) & 89 & Hollow tree or hollow bole section \\
\hline 42 & Ungulate feeding/rubbing & 90 & Beaver (feeding/harvesting) \\
\hline 43 & Domestic livestock (rubbing) & $91-96$ & Hawksworth Mistletoe Rating System \\
\hline 44 & Nest & 97 & Available for future consideration \\
\hline 45 & Other mammalian/avian evidence & 98 & Data changed by office \\
\hline 46 & Sweep/Bow/Bend & 99 & Do not look for tree \\
\hline
\end{tabular}


. 


\section{CONDITION CODES DESCRIPTION}

\begin{tabular}{|c|c|c|}
\hline \multicolumn{2}{|c|}{ Condition Codes } & Description \\
\hline 00 & Healthy & No Defect. \\
\hline 01 & Insects & $\begin{array}{l}\text { Damage or mortality due to destruction of plant parts or tissue by insects. } \\
\text { Look for evidence of eggs, egg cases, nests, chewed plant parts, etc. } \\
\text { Similar signs on plants located off site may aid in identification of insect } \\
\text { mortality. }\end{array}$ \\
\hline & Disease & $\begin{array}{l}\text { Damage or mortality caused by disease or fungi. Cankers, discoloration, } \\
\text { rust spotting, fungal coverings, etc. help to identify mortality under this code. }\end{array}$ \\
\hline & Rabbit Browsing & $\begin{array}{l}\text { Trees killed or damaged by rabbits can be identified by clean, sharp cut marks along } \\
\text { the branches and stems (approximately } 45^{\circ} \text { angles). Chewed bark and needles also } \\
\text { indicate rabbit damage. }\end{array}$ \\
\hline 04 & Shepherd's Crook & $\begin{array}{l}\text { Damage results in blackening and wilting of young shoots and leaves. Tips of the } \\
\text { blackened shoots often bend back. On older leaves brownish black, irregularly } \\
\text { shaped spots appear. }\end{array}$ \\
\hline 05 & $\begin{array}{l}\text { Browsing (other } \\
\text { animals) }\end{array}$ & $\begin{array}{l}\text { Mortality or damage due to browsing by ungulates or other animals (e.g. moose, } \\
\text { cattle, beavers). Look for chewed tops with rough cuts or breaks. }\end{array}$ \\
\hline 06 & Fire & $\begin{array}{l}\text { Mortality or damage due to actual burning of the seedling or scorching by nearby } \\
\text { flames. Not to be used when seedlings are killed by sun scald. }\end{array}$ \\
\hline 07 & Mechanical & $\begin{array}{l}\text { Trees killed or damaged by mechanical or physical means such as scarification } \\
\text { machinery, trampling or crushing by animals, etc. Stem scars and rough breakage } \\
\text { help to identify mortality under this code. }\end{array}$ \\
\hline 08 & WindThrow & $\begin{array}{l}\text { Damage or mortality due to crushing by fallen or displaced logs, snags, branches, } \\
\text { uprooted trees, etc. }\end{array}$ \\
\hline & Climate & $\begin{array}{l}\text { Trees damaged or killed solely by climatic factors. These include death by freezing, } \\
\text { sun scald, severe desiccation, ice accumulation, red belt, etc. }\end{array}$ \\
\hline & Flooding & $\begin{array}{l}\text { Trees damaged or killed by drowning alone. Look for evidence of high water marks } \\
\text { on the seedling, or in the immediate area. Pull tree out of ground and check roots to } \\
\text { see if the root outer coverings is falling off and is blackened. }\end{array}$ \\
\hline 11 & Poor Planting & $\begin{array}{l}\text { Damage or mortality due to improper placement of nursery stock (hand or } \\
\text { mechanical planting). Trees may have been planted too deep, too shallow, too } \\
\text { loosely, or at an acute angle. }\end{array}$ \\
\hline & Suppression & $\begin{array}{l}\text { Trees which have been suppressed by the surrounding vegetation for a period of } \\
\text { time long enough to damage or kill them. Mortality may be due to severe lack of } \\
\text { light, water, nutrients (removed by the competition) or by physical smothering (i.e. } \\
\text { heavy grasses). Reference to the previous year's damage tally may help in } \\
\text { determining this mortality call. A tree that is over topped by grass or shrubs is not } \\
\text { necessarily suppressed. Look for a spindly main stem with very few long needles } \\
\text { spaced wide apart or evaluate the last five increments. If the tree has only grown } \\
1 \mathrm{~cm} \text { a year, it is probably suppressed. }\end{array}$ \\
\hline & Frost Heaving & $\begin{array}{l}\text { This code is used only when mechanical frost action can be clearly identified as the } \\
\text { direct cause of damage or mortality. Usually upheaval and separation of the } \\
\text { seedling's root system from the soil occurs as a result of ice lens formation. This is } \\
\text { most commonly associated with containerized seedlings planted in silty soil. }\end{array}$ \\
\hline & Erosion & $\begin{array}{l}\text { Damage or mortality due to the removal of the seedling's seedbed, by the forces of } \\
\text { water, wind or soil slumping. Trees killed by partial or total burial (deposited soil or } \\
\text { organic matter) would also be tallied using this code. }\end{array}$ \\
\hline
\end{tabular}




\begin{tabular}{|c|c|c|}
\hline & Missing & $\begin{array}{l}\text { This code is to be used when a seedling from the previous year's measurement } \\
\text { cannot be located. It can also be used where the seedling was removed from the } \\
\text { site and probably died (i.e. tag found, no morphological signs of live seedling } \\
\text { remaining). Using in conjunction with code } 25 \text { ONLY. }\end{array}$ \\
\hline 16 & Dead top/Dieback & $\begin{array}{l}\text { Top is dead (die back) without any indication of insect or climate (frost) damage. } \\
\text { See Figure } 4.31\end{array}$ \\
\hline 17 & Poor Seedbed & $\begin{array}{l}\text { This code is to be used only when the cause of death or damage for a seedling can } \\
\text { be traced to the type of seedbed on which it is growing. In most cases the seedling } \\
\text { will show signs of desiccation due to the poor moisture holding capacity of the } \\
\text { seedbed material (e.g. rotten logs, dry clay). }\end{array}$ \\
\hline 18 & Herbicide & $\begin{array}{l}\text { Should only be used when the cutblock (or parts of the cutblock) has received a } \\
\text { recent herbicide treatment; either before or after the stock was in place. Spruce } \\
\text { seedlings exhibit needle loss and/or reddish brown coloration of stems and foliage. } \\
\text { Deciduous species exhibit yellowish/brown leaf mottling and dieback of terminal } \\
\text { growth. Hexazinone causes reddish brown coloration of conifer foliage and needle } \\
\text { loss. Deciduous foliage turns red to black. Glyphosate causes chlorosis especially } \\
\text { in new growing shoots. 2,4-D causes rapid growth and spiralling and twisting. If } \\
\text { applied during conifer flush bad dieback similar to frost damage may occur. Often } \\
\text { chemical damage will also be indicated by phytotoxicity spotting on exposed foliage. }\end{array}$ \\
\hline 19 & $\begin{array}{l}\text { Western Gall Rust } \\
\text { (only in Pine) }\end{array}$ & $\begin{array}{l}\text { This code is used when Lodgepole pine damage or death can be attributed to } \\
\text { Western Gall Rust. This is usually clearly identifiable due to swelling of succulent } \\
\text { tissue (and subsequent formation of a gall) and the bright orange spores produced in } \\
\text { that affected area. This gall can be on the main stem or a lateral branch. }\end{array}$ \\
\hline 20 & Armillaria Root Rot & $\begin{array}{l}\text { This code is utilized when a seedling is damaged or killed by Armillaria Root Rot. } \\
\text { Identification of the disease is in recognizing mycelial fans of the cambium of } \\
\text { damaged and dead trees. Pull tree out of ground and examine root collar. }\end{array}$ \\
\hline 21 & Moldy Planting Stock & $\begin{array}{l}\text { This code is usually used on Bareroot Planting Stock. Grey mold will usually be } \\
\text { found around the root collar and lower branches. }\end{array}$ \\
\hline 22 & Multiple Leader & $\begin{array}{l}\text { When a tree has two or more leaders, but is otherwise healthy this code should be } \\
\text { entered. The tree is considered multiple leader if all leaders are within } 5 \mathrm{~cm} \text { (height) } \\
\text { of each other. This code also applies to saplings and regeneration that appear } \\
\text { forked. Be aware of normal branching of deciduous trees. }\end{array}$ \\
\hline 23 & Poor Form & $\begin{array}{l}\text { This code is used on trees, which exhibit a general poor form, due to previous } \\
\text { damage. } \mathrm{DBH}<9.1 \text { See code } 66 \text { for }>9.1 \mathrm{DBH}\end{array}$ \\
\hline 24 & $\begin{array}{l}\text { Broken Top (DBH } \\
<9.1) \text { (see " } 56 \text { " for } \\
\mathrm{DBH}>9.1 \text { ) }\end{array}$ & $\begin{array}{l}\text { It should be used as long as the broken top is noticeable and has some effect on the } \\
\text { growth of the tree. }\end{array}$ \\
\hline 25 & $\begin{array}{l}\text { Dead Tree Standing } \\
\text { (No CC) }\end{array}$ & $\begin{array}{l}\text { Tree has no signs of being alive. A standing dead tree is one that is dead but still } \\
\text { standing. No green foliage or buds present. The tree must be able to withstand a } \\
\text { firm push. Record a diameter and species but do not record height. Pound nail } \\
\text { into tree. No crown class. }\end{array}$ \\
\hline 26 & Snow Press (No CC) & $\begin{array}{l}\text { This code is normally used for trees that show signs of being pressed down to the } \\
\text { ground for a few years after germinating. May Happen to bigger trees. See Figure } \\
4.8\end{array}$ \\
\hline 27 & $\begin{array}{l}\text { Dead Top Dieback } \\
\text { with New Leader }\end{array}$ & $\begin{array}{l}\text { This refers to stems that have had previous leader damage and a new leader has } \\
\text { formed. }\end{array}$ \\
\hline 28 & $\begin{array}{l}\text { Sucker(s) (From Old } \\
\text { stump) }\end{array}$ & $\begin{array}{l}\text { Refers to stems that have been cut-down through thinning and have started to } \\
\text { sucker. Do not re-use the previous stem number, but assign a new number to each } \\
\text { sucker. }\end{array}$ \\
\hline 29 & Cutdown & Self explanatory. \\
\hline 30 & Terminal Weevil & $\begin{array}{l}\text { Terminal leaders of Pine or Spruce bend over and die. Two or more years growth } \\
\text { are affected. Bore Holes which are exit holes for the larvae MUST be present to }\end{array}$ \\
\hline
\end{tabular}




\begin{tabular}{|c|c|c|}
\hline & & use this code. \\
\hline & SW Gall Adelgid & $\begin{array}{l}\text { Adelgid galls on spruce located at the end of new growth and may persist for many } \\
\text { years. }\end{array}$ \\
\hline 32 & Tent Caterpillar & A tent of silk forms on the tree and the caterpillars defoliate the tree. \\
\hline 33 & Root Collar Weevil & $\begin{array}{l}\text { This weevil feeds mainly on } \mathrm{Sw}, \mathrm{Pj} \text { and PI. They feed in the bark and cambial area } \\
\text { of the host tree at or below the duff surface, causing copious flows of resin. The } \\
\text { tunnels often girdle small trees. This insect allows root rots to enter the tree. }\end{array}$ \\
\hline & J-Root & $\begin{array}{l}\text { This code is used after the tree has had a poor planting code in the previous } \\
\text { measurement. }\end{array}$ \\
\hline 35 & $\begin{array}{l}\text { Leaning (No CC) see } \\
\text { code } 58\end{array}$ & Tree leaning more than $20 \%$ off of vertical axis. \\
\hline 36 & Same Stump & $\begin{array}{l}\text { Used when } 2 \text { or more trees can be distinguished above ground level but below DBH. } \\
\text { Used a lot on Deciduous that have been cutdown and resprouted at stump. }\end{array}$ \\
\hline 37 & Unknown & $\begin{array}{l}\text { This condition code is to be used only when there appears to be something affecting } \\
\text { the tree but the other condition codes do not describe the situation. This would } \\
\text { include burnt trees etc. A description of what is affecting the tree should be included } \\
\text { as well in the comments column. In the event that this code is used for more than } \\
5 \% \text { of the tallies, it is up to the crew leader or a forester to decide on the cause of the } \\
\text { condition. }\end{array}$ \\
\hline & Pitch Moth & $\begin{array}{l}\text { Primary host is Lodgepole Pine. May weaken or kill the terminal leader, resulting in } \\
\text { stem deformities and height growth reduction. Blisters are mainly on main stem and } \\
\text { are characteristic resin coated up to } 20 \mathrm{~mm} \text { in diameter. }\end{array}$ \\
\hline 39 & $\begin{array}{l}\text { DBH Taken on New } \\
\text { Leader }\end{array}$ & \\
\hline 40 & Nutrient Deficiency & $\begin{array}{l}\text { This may occur on blocks that have had the humus layer removed by scarification } \\
\text { (i.e.; Blade). Trees are chlorotic and usually in bare mineral soil. Usually noted on } \\
\text { spruce. May be confused with flooding damage. }\end{array}$ \\
\hline & Mouse Feeding & $\begin{array}{l}\text { Mice and voles can girdle seedlings and consume seeds. See Rangen and Roy } \\
\text { (1997) for more detail. }\end{array}$ \\
\hline 42 & $\begin{array}{l}\text { Ungulate } \\
\text { feeding/rubbing }\end{array}$ & $\begin{array}{l}\text { Ungulate feeding on twigs is generally recognized by the ragged appearance of twig } \\
\text { terminals. Rubbing of trees as antler rubs and feeding on bark also occurs; these } \\
\text { conditions are further described in Rangen and Roy (1997). Antler rubs can also be } \\
\text { associated with "scrapes" (smaller patches of scraped ground) and small tufts of hair } \\
\text { on twigs. If the bark on aspen trees has been consumed ensure that ungulates (as } \\
\text { opposed to other mammals) are responsible. The extent of the bitten area, track } \\
\text { identity and grooves that indicate tooth size and pattern should all be inspected in } \\
\text { order to differentiate ungulate bark feeding from similar feeding by small mammals } \\
\text { (i.e. see code number } 86 \text { and applicable photograph). }\end{array}$ \\
\hline 43 & $\begin{array}{l}\text { Domestic livestock } \\
\text { (rubbing) }\end{array}$ & $\begin{array}{l}\text { Rangen and Roy (1997) describe rubbing of trees by livestock; rubbed trees are } \\
\text { occasionally seen in areas where cattle grazing occurs. If this code is used, ensure } \\
\text { that other signs in general area (i.e. presence of cattle droppings, cow trails and } \\
\text { grazed vegetation) also supports this. }\end{array}$ \\
\hline & Nest & $\begin{array}{l}\text { This code indicates the presence of a nest on a given tree in the PSP. It refers only } \\
\text { to an "open" nest; cavity nests are excluded from this category, as it is difficult to } \\
\text { ascertain if a given cavity is indeed used as a nest site. Field guides that assist with } \\
\text { the identification of "open" nests are available (see Harrison 1979). Of particular } \\
\text { importance are colonial complexes of large nests on islands in lakes. Mammalian } \\
\text { nests also exist and should be indicated as such if this is known. To do this, use the } \\
\text { comments section which applies to a given tree and indicate as required. If the } \\
\text { occupants of the nest can be identified, the identity can also be entered in the } \\
\text { comments section. }\end{array}$ \\
\hline
\end{tabular}


45 Other mammalian/avian evidence

Other agents (i.e. bears, grouse, shrew, pocket gophers) which leave evidence on trees or leave evidence closely associated with trees are described in Rangen and Roy (1997). Pocket gophers leave soil mounds (Rangen and Roy - (1997). Bears can leave a characteristic series of claw marks on aspen trees, indicating that the tree was scaled, and rotted stumps/logs are also occasionally ripped apart. In addition, it has been suggested that bark on live trees is occasionally consumed (see Hiratsuka 1987 for a depiction). Ensure that ripped up stumps/logs, etc. are accompanied by other evidence of bear.

46 Sweep/Bow/Bend Is a gradual bowing or curving of the main tree system. It has no decay significance but may cause a loss of volume in a sawlog.

47 Witches Broom

Yellow witches broom is the most conspicuous disease of spruce in the province. Can be recognized from a distance. See Figure 4.10

48 Frost Crack

A frost crack is a deep radial splitting of a trunk caused by an uneven shrinkage of the wood after a sudden drop in temperature. The cracks usually start at the base and extend up the trunk. They may re-opened. repeatedly by wind stresses or a low temperature.

49 Dying Tree is in distress and will die before next measurement.

51 Conk/Blind Conks Conks appear most frequently on the underside of dead branch stubs or on the underside of live branches in the crown. Conks, by definition, are woody, shelfilike basidiocarps (fruiting bodies) of wood-rotting fungi. See Figure 4.3

52 Open Scars Open scars are wounds which have been penetrated through to the cambium. These wounds must not be healed over and may be caused by a variety of reasons such as fire, lightning, old blazing, machinery, animals, etc. Scars are considered to be entry points for decay fungi. Open scars are illustrated in Figure 4.4. Animal damage usually penetrates the cambium therefore code as an open scar. A common mistake is to call stem disease such as atropellis canker an open scar. See Figure 4.4

$53 \quad$ Burls and Galls Burls are abnormal swelling of the main stem or branches resulting from abnormal wood cell development following disturbance to the cambial layer. A burl is illustrated in Figure 4.5.

Galls are localized trunk and branch swelling of mainly tissue. There is little or no damage to the underlying wood.

$54 \quad$ Fork

Forks usually develop when there is malformation, injury or death of the terminal leader. Forks tend to be V-shaped and will only be recorded when above $1.3 \mathrm{~m}$ (DBH level). Forks below this point are recorded as same stump (condition code 36). Natural branching on deciduous trees is not to be recorded. Figure 4.6 demonstrates the difference between forks and natural branching.

55 Pronounced Crook This condition develops from the death of the terminal leader or the breaking off of a forked leader. When this occurs, a lateral branch takes over apical dominance as shown in Figure 4.7.

56 Broken Top (No CC) (see "24" for $\mathrm{DBH}<9.1)$

57 Limby Broken tops occurs usually in the top third of the tree. No Crown Class.

\begin{tabular}{|c|l|l|} 
for DBH $<9.1)$ & \\
\hline 57 & Limby & $\begin{array}{l}\text { A tree is recorded as limby if more than } 75 \% \text { of the tree has live, low sweeping } \\
\text { branches. Usually branches on coniferous }>2.0 \mathrm{~m} \text { on any part of tree could be } \\
\text { considered limby. }\end{array}$ \\
\hline 58 & $\begin{array}{l}\text { Severe Lean (No CC) } \\
\text { see code 35 }\end{array}$ & $\begin{array}{l}\text { A tree is considered leaning if it is standing greater than } 20^{\circ} \text { off of vertical (see } \\
\text { Figure 4.8). If the angle is greater than } 45^{\circ} \text { to the ground, the tree has a severe lean. } \\
\text { No crown class if severe. }\end{array}$ \\
\hline
\end{tabular}




\begin{tabular}{|c|c|c|}
\hline 59 & Broken Stem (No CC) & $\begin{array}{l}\text { A broken stem is recorded if the tree bole broken. Usually found in bottom } 2 / 3 \text { of the } \\
\text { tree. No crown class. }\end{array}$ \\
\hline 60 & $\begin{array}{l}\text { Generic woodpecker } \\
\text { feeding (often } \\
\text { smaller species) }\end{array}$ & $\begin{array}{l}\text { Figure } 4.13 \text { indicates feeding by woodpeckers. Species such as the Black-backed } \\
\text { woodpecker and Three-toed woodpeckers will often leave signs like this on old } \\
\text { coniferous trees, and Hairy and Downy woodpeckers typically peel off scales } \\
\text { ("scale") and "peck" the bark as do Pileated woodpeckers in summer months } \\
\text { (Conner 1979). Note the evidence of very small holes (arthropods) and holes made } \\
\text { by the woodpeckers themselves. The appearance of tree trunks fed on in this } \\
\text { manner is often reddish from a distance. }\end{array}$ \\
\hline 61 & $\begin{array}{l}\text { Dead and Down (No } \\
\text { CC) }\end{array}$ & $\begin{array}{l}\text { A dead and down tree is one that was previously tagged and measured in a PSP plot } \\
\text { but at the present time is now dead and no longer standing. The cause of death } \\
\text { must be by natural causes (i.e. windfall, beavers, insect or disease, etc.). No crown } \\
\text { class. }\end{array}$ \\
\hline 62 & $\begin{array}{l}\text { Stem Insects (Bark + } \\
\text { Sawyer Beetles) }\end{array}$ & $\begin{array}{l}\text { This code is recorded when there is evidence of an insect infestation attacking the } \\
\text { bole of the tree. Bark beetles are the most prevalent stem insects but sawyer } \\
\text { beetles and others are included. Bark beetles, Dendroctonus spp., are a very } \\
\text { serious problem in Alberta. The adult female enters the bark in early summer and } \\
\text { lays eggs in the tree's cambium. The eggs overwinter and hatch as larvae in the } \\
\text { early spring. Damage to the tree is done by the larvae eating the cambium and } \\
\text { usually results in death. The tree will not turn red until the next summer. Other } \\
\text { symptoms of attack are piles of "sawdust" (frass) at the base of the tree, entry holes } \\
\text { in the bark, and pitch tubes (the tree tries to push the beetles out with resin). The } \\
\text { beetles also carry a blue stain that causes further deterioration of wood quality. } \\
\text { Beetles attack all species of pines, spruce, and Douglas fir. Sawyer beetle } \\
\text { infestations are common in burned timber. }\end{array}$ \\
\hline \multirow[t]{4}{*}{63} & \multirow[t]{4}{*}{$\begin{array}{l}\text { Stem Disease } \\
\text { (Cankers) }\end{array}$} & $\begin{array}{l}\text { All diseases that infect the main stem are documented with this code. Included in } \\
\text { this code are cankers, rusts, rotten branches and root rot. } \\
\text { Stem cankers are caused by fungi that invade stems and branches resulting in } \\
\text { localized areas of infection in the bark and underlying wood tissue. Cankers may be } \\
\text { annual or perennial. In perennial cankers the infected area may be eventually } \\
\text { exposed to the underlying wood when the deadbark sloughs off. A common stem } \\
\text { canker on lodgepole pine is Atropellis piniphila (Figure 4.9). Exudation of resin from } \\
\text { the bark surface is the first external symptom. They are sunken elongated on one } \\
\text { side of the trunk and indicate resin flow. This can cause a distortion in growth and a } \\
\text { blue-black stain on the wood. }\end{array}$ \\
\hline & & $\begin{array}{l}\text { Stem rusts are also included in this condition code. Rusts are host specific parasitic } \\
\text { fungi usually requiring two alternating living hosts. Stems and branches may be } \\
\text { girdled resulting in large malformations or even death. In particular, Endrocronartium } \\
\text { harknessii on young pines is a serious problem in Alberta. Spruce broom rust, } \\
\text { Chrysomyxa arctostaphi (see Figure } 4.10) \text {, can also be noted but only if the broom is } \\
\text { no longer green (i.e. red or missing needles). }\end{array}$ \\
\hline & & $\begin{array}{l}\text { Large rotten branches typically appear on overmature, decadent trees and can be } \\
\text { indicative of decay. Large rotten branches are those well below the base of the live } \\
\text { Crown and are }>5 \mathrm{~cm} \text { in diameter, are unweathered, appear punky, and are } \\
\text { weeping. Often a black ring appears on the stem surrounding the branch. }\end{array}$ \\
\hline & & $\begin{array}{l}\text { Some of the typical symptoms of Armillaria root rot are reddish brown or yellowish } \\
\text { foliage; mycelial fans form between the bark and wood around the base; fungal } \\
\text { (shoestring) strands in the soil surrounding the diseased roots and honey } \\
\text { mushrooms growing around the base of the diseased tree. }\end{array}$ \\
\hline
\end{tabular}




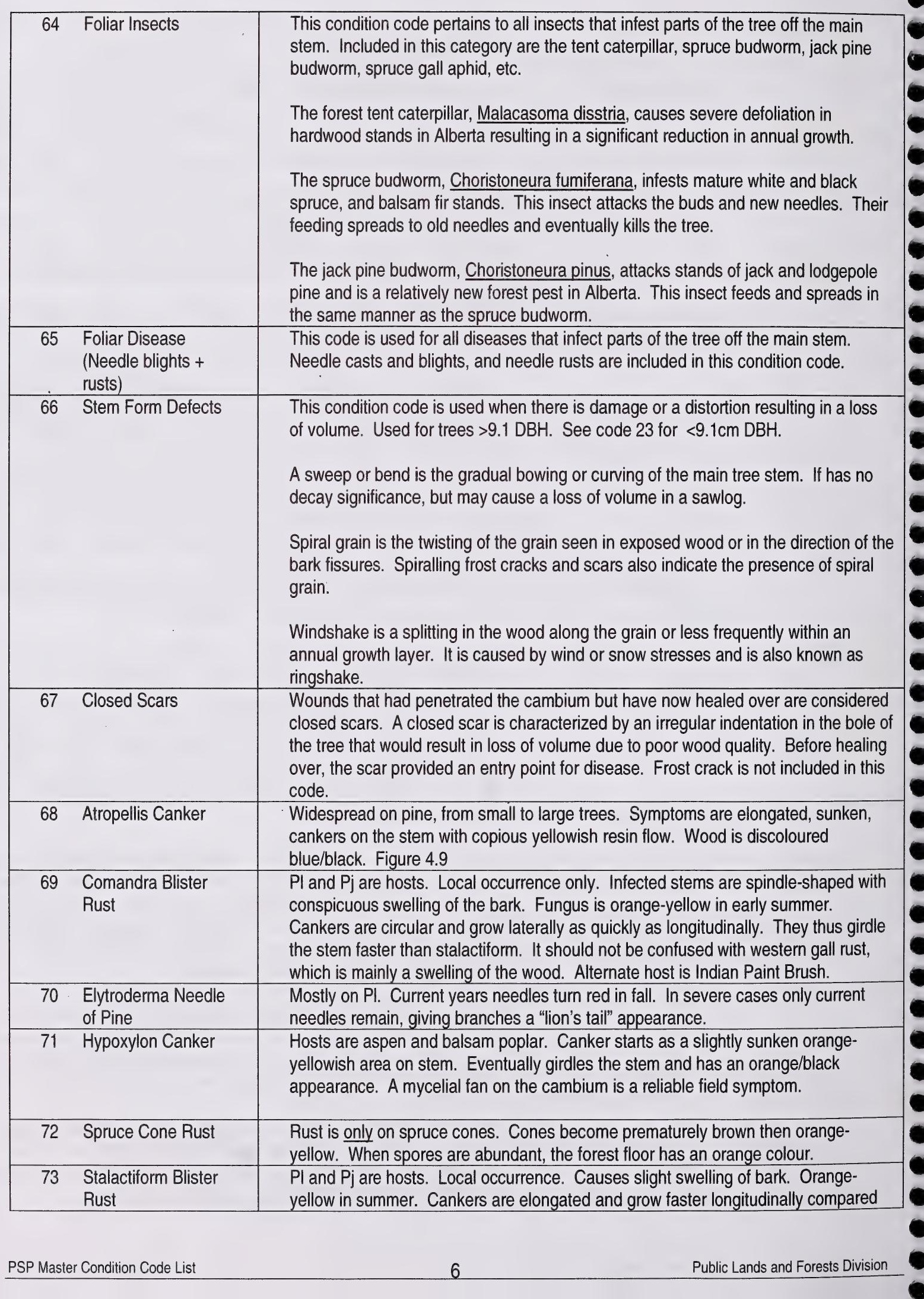




\begin{tabular}{|c|c|c|}
\hline & & to Comandra. Alternate host is Bastard Toad Flax. \\
\hline & $\begin{array}{l}\text { Tomentosus Root } \\
\text { Rot }\end{array}$ & $\begin{array}{l}\text { Most important on Sw and Sb. Symptoms are excessive branch mortality, thinning } \\
\text { of crown and openings in the stand. Disease develops slowly (over 15-20 years) so } \\
\text { is not so obvious in regenerating stands. }\end{array}$ \\
\hline 75 & Spruce Spanworm & $\begin{array}{l}\text { Chiefly affects aspen. Damage shows mostly as holes in the leaves. Resembles } \\
\text { forest ten caterpillar but no pupal cases or egg masses on the foliage. Caterpillars } \\
\text { are typically light green and have one prominent and two indistinct yellowish lines } \\
\text { along each side of the body. The head is dark-brown. }\end{array}$ \\
\hline 76 & $\begin{array}{l}\text { Spruce Cone } \\
\text { Maggot }\end{array}$ & $\begin{array}{l}\text { No external symptoms. Dissected cone shows frass-filled spiral tunnel around the } \\
\text { central axis. }\end{array}$ \\
\hline 77 & Spruce Cone Worm & Feeding larvae expel frass, which adheres to silken webbing on cone surface. \\
\hline 78 & $\begin{array}{l}\text { Eastern Spruce } \\
\text { Budworm }\end{array}$ & $\begin{array}{l}\text { First symptoms are webbing and frass in buds or on previous year's needles. Later, } \\
\text { webbing is spun on branch tips. By late June tree crowns appears rust brown. }\end{array}$ \\
\hline 79 & $\begin{array}{l}\text { Mountain Pine } \\
\text { Beetle }\end{array}$ & $\begin{array}{l}\text { Main host is PI. Symptoms are standing dead trees with beetle exit boles about eye- } \\
\text { level. Accumulations of pitch or sawdust are conspicuous around entrance holes } \\
\text { bored into the bark of trees by adult beetles from mid-July to mid-August. }\end{array}$ \\
\hline 80 & Spruce Beetle & $\begin{array}{l}\text { Host are Sw and Se. Symptoms are standing dead trees with beetle exit holes about } \\
\text { eye-level. Conspicuous boring dust accumulates on bark below holes until the wind } \\
\text { blows it away. }\end{array}$ \\
\hline 81 & Spruce Needle Rust & $\begin{array}{l}\text { Feed on needles in the upper crown of the tree. Partly chewed needles and needle } \\
\text { stubs impart a brownish color and ragged appearance to the foliage. No webbing } \\
\text { present. Found on all spruce. }\end{array}$ \\
\hline 82 & $\begin{array}{l}\text { Yellow-Headed } \\
\text { Spruce Sawfly }\end{array}$ & $\begin{array}{l}\text { Discoloration of needles. May find dotlike sexual fruiting structures on needles. } \\
\text { Infected needles drop prematurely. }\end{array}$ \\
\hline 83 & Large Aspen Tortrix & $\begin{array}{l}\text { Affected foliage has a clumped, irregular appearance and leaves do not move as } \\
\text { freely in the wind as uninfested leaves. Larval instars feed within rolled leaves or } \\
\text { within } 2 \text { or more leaves pulled together and secured with silken webbing. }\end{array}$ \\
\hline 84 & $\begin{array}{l}\text { Excavations by } \\
\text { woodpeckers (likely } \\
\text { Pileated woodpecker) }\end{array}$ & $\begin{array}{l}\text { Feeding by Pileated woodpecker can occur on dead or scenescent deciduous and } \\
\text { coniferous trees, and feeding holes (as indicated in the figures below) are thought to } \\
\text { occur towards the base of the tree (Rangen and Roy 1997). Excavated holes } \\
\text { indicate subcambial penetration (holes penetrate beneath the bark and into the } \\
\text { sapwood) and large wood chips can be associated with excavations. Excavated } \\
\text { feeding holes can be large (Figure 4.16). In such excavations, evidence of carpenter } \\
\text { ants (burrows, sawdust) or other boring arthropods might also be found in the } \\
\text { sapwood. In living trees with a sound bole, initial feeding holes might be more } \\
\text { restricted such as that indicated in Figure } 4.12 \text {. Elsewhere in North America, the } \\
\text { Pileated woodpecker has been found to excavate holes extensively in winter and to } \\
\text { a grater extent that other woodpeckers (Conner 1979). The Hairy woodpecker might } \\
\text { also create deeper holes in trees, however, it is considered an opportunistic feeder } \\
\text { (Sousa 1987) and spends a smaller portion of its time "excavating" during winter } \\
\text { months (Conner 1979). In lowa, it has also been found to generally feed at higher } \\
\text { locations in trees (5-7m) (Sousa 1987). If this feeding evidence exists on a given } \\
\text { tree, indicate in comments its extent (i.e. restricted, such as in Figure 4.16). }\end{array}$ \\
\hline 85 & $\begin{array}{l}\text { Yellow-bellied } \\
\text { sapsucker feeding }\end{array}$ & $\begin{array}{l}\text { Figure } 4.14 \text { illustrates the characteristic pattern of regularly spaced small holes left } \\
\text { by Yellow-bellied sapsucker (also see Hiratsuka } 1987 \text { for another depiction of } \\
\text { sapsucker feeding). These are often found on birch, however they also have been } \\
\text { observed on willows, and have been reported on aspen and pine (Rangen and Roy } \\
\text { 1997, Hiratsuka 1987). }\end{array}$ \\
\hline 86 & $\begin{array}{l}\text { Small mammal } \\
\text { feeding on tree bole } \\
\text { (hare,porcupine, } \\
\text { squirrel, bushy-tailed }\end{array}$ & $\begin{array}{l}\text { Figure } 4.15 \text { is an example of feeding by hare on small saplings. In this case the bark } \\
\text { was bitten off. When hares feed on twigs, it is generally thought that twigs are } \\
\text { clipped off in a characteristic razored fashion (Figure 106, Rangen and Roy, 1997). } \\
\text { Small mammals such as porcupine, woodrat and squirrel might also feed on bark }\end{array}$ \\
\hline
\end{tabular}




\begin{tabular}{|c|c|c|}
\hline & woodrat) & $\begin{array}{l}\text { however, if such feeding evidence occurs high in trees, one could probably rule out } \\
\text { hare because hare do not climb trees (also see Hiratsuka } 1987 \text { for a depiction of } \\
\text { porcupine feeding on pine). Ensure other evidence (i.e. tracks, pellets, etc.) } \\
\text { Supports a specific determination of the agent involved. Also refer to Rangen and } \\
\text { Roy (1997) for more information on how to identify the specific causes of girdling and } \\
\text { refer to Murie (1975) for assistance on identifying tracks if this is required. Evidence } \\
\text { of squirrel feeding is common and could also be indicated, however, the value of this } \\
\text { information is probably less valuable. }\end{array}$ \\
\hline & Small Cavity & $\begin{array}{l}\text { Small woodpeckers create small cavities (approximately } 5 \mathrm{~cm} \text { in diameter) in snags } \\
\text { and stubs (Figure } 4.17 \text { ), however, height of the cavity above ground probably varies. } \\
\text { Among the species which might use such cavities are smaller woodpeckers, kestrel, } \\
\text { chickadee, nuthatch, swallow, wren, flycatchers, and small mammals (etc). One } \\
\text { could explore whether such cavities are occupied by rubbing the bark with a stick. } \\
\text { Should a cavity be occupied the occupant (if known) should be identified in the } \\
\text { comments section. }\end{array}$ \\
\hline 88 & Large Cavity & $\begin{array}{l}\text { A large cavity is a round/excavated opening greater than or equal to } 10 \mathrm{~cm} \text { in } \\
\text { diameter (see Figure 4.18). The cavity in the figure was approximately } 15 \mathrm{~m} \text { high. } \\
\text { Pileated woodpeckers have been known to excavate such cavities, however, a } \\
\text { variety of species (birds as well as mammals) may use them as nest sites, roosting } \\
\text { sites or dens. As in the case of smaller cavities, one could investigate the identity of } \\
\text { the occupant by rubbing/tapping the bark of such trees with a stick. If might be } \\
\text { possible to ascertain the identity of the tracks which are associated with the cavity, } \\
\text { during winter, by checking surrounding snow cover and identifying tracks that appear } \\
\text { to lead towards the cavity in the tree (see Murie 1975). }\end{array}$ \\
\hline 89 & $\begin{array}{l}\text { Hollow tree or hollow } \\
\text { bole section }\end{array}$ & $\begin{array}{l}\text { Hollow trees can be used as denning sites by bats and other birds and mammals. } \\
\text { This condition code should be used to identify these sites. }\end{array}$ \\
\hline 90 & $\begin{array}{l}\text { Beaver (feeding- } \\
\text { /harvesting) }\end{array}$ & $\begin{array}{l}\text { Beaver girdle large trees in a characteristic fashion and evidence of their harvesting } \\
\text { activities (i.e. cone shaped stumps) are well known to many. Refer to Rangen and } \\
\text { Roy (1997) and Hiratsuka (1987) for more details. }\end{array}$ \\
\hline \multicolumn{2}{|c|}{$\begin{array}{l}\text { 91-96 Hawksworth } \\
\text { Mistletoe Rating } \\
\text { System }\end{array}$} & $\begin{array}{l}\text { Dwarf mistletoes are parasitic flowering plants requiring living hosts. Mistletoe is } \\
\text { usually recognized by swellings on branches and stems or by witches brooms. } \\
\text { Heavy infestation makes trees susceptible to secondary attack (such as bark } \\
\text { beetles), lower wood quality and growth losses (can be from } 30-60 \% \text { ). The major } \\
\text { tree hosts in Alberta are: lodgepole pine, Douglas fir and larch. Figure } 4.11 \\
\text { illustrates the effect resulting from mistletoe infestations and the individual flowering } \\
\text { plant. } \\
\text { The Hawksworth Rating System for mistletoe is used to determine the severity of } \\
\text { mistletoe infestation on individual trees. Figure } 4.12 \text { outlines instructions and gives } \\
\text { an example of the use of the 6-class mistletoe rating systems (Hawksworth } 1961 \text {, } \\
\text { 1977). If a tree has mistletoe, record only the } 90 \text { series code, do not record } 33 \\
\text { unless there is a second distinct foliar disease. }\end{array}$ \\
\hline 97 & $\begin{array}{l}\text { Available for future } \\
\text { consideration }\end{array}$ & \\
\hline 98 & $\begin{array}{l}\text { Data changed by } \\
\text { office }\end{array}$ & \\
\hline 99 & Do not look for Tree & \\
\hline
\end{tabular}





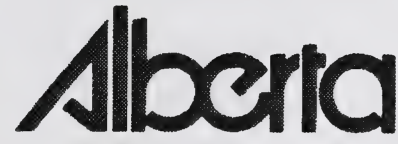

SUSTAINABLE RESOURCE DEVELOPMENT

\section{PSP MANUALS MASTER APPENDICES}

\section{MARCH 2005}

Public Lands and Forests Division Forest Management Branch

$8^{\text {th }}$ FI. $9920-108$ Street

Edmonton, $A B$

T5K 2M4

Phone: (780) 427 - 8474

Or visit the website: http://www3.gov.ab.ca/srd/forests/psp 


\section{TABLE OF CONTENTS}

1. SUGGESTED EQUIPMENT AND SUPPLIES.

2. PLOT TOPOGRAPHY

a. Location

3. SOIL CODES

a. Erosion potential.

b. Drainage Codes

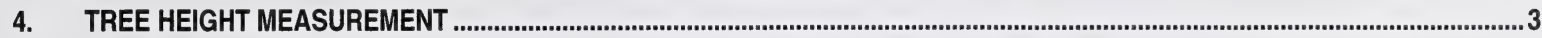

a. Determining Tree Height with a Laser Clinometer or Haglof Vertex ..................................................................................

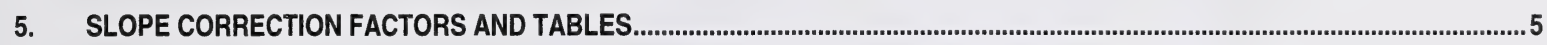

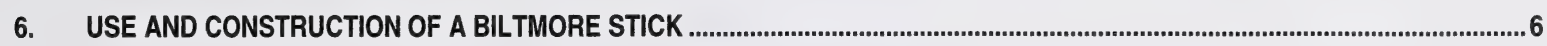

7. ACCESS EVALUATION CODES

8. LEGAL SURVEY SYSTEM OF ALBERTA

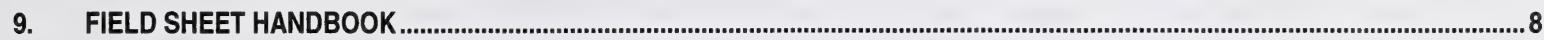

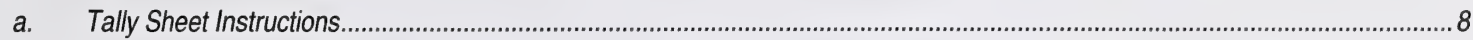

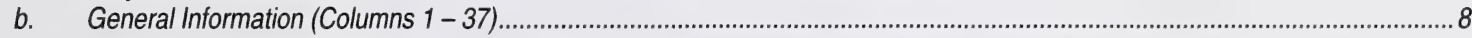

c. Record 01 - Header Information (Columns 38-212) ....................................................................................................11

d. Record 02 - Tree Information - header Sheet (Columns 1-37) - Tally Sheet (Columns 38-124).........................................17

e. Record 03 - Regen Information (Columns 38-85) ..............................................................................................................2

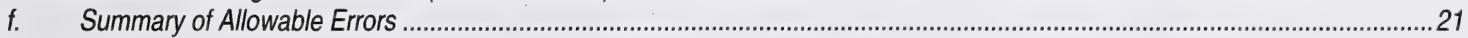

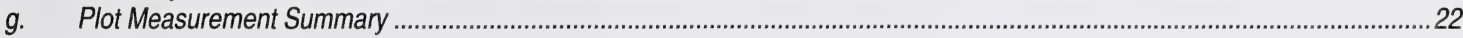

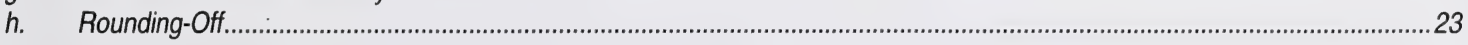

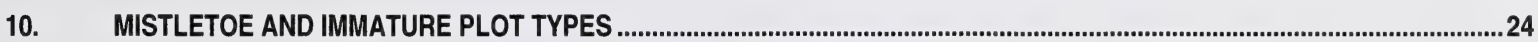

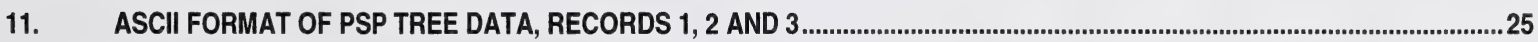

a. RECORD TYPE "01" - STANDARD SAMPLE PLOT HEADER RECORDS ……...............................................................2

b. RECORD TYPE "02" - STANDARD TREE DESCRIPTION RECORD ……...................................................................29

c. RECORD TYPE "O3" - STANDARD REGENERATION RECORD

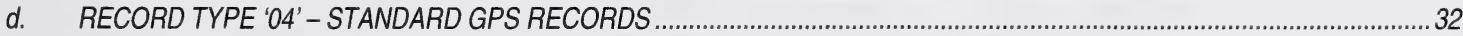

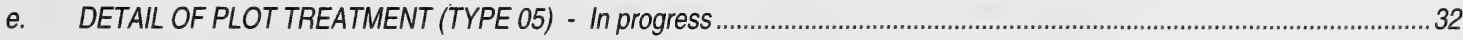

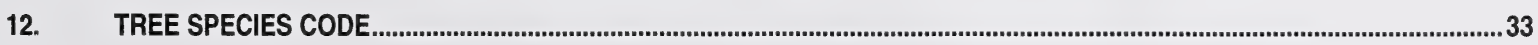

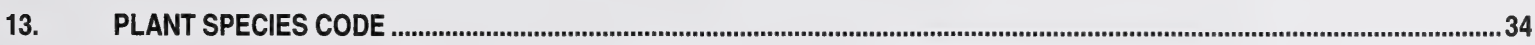

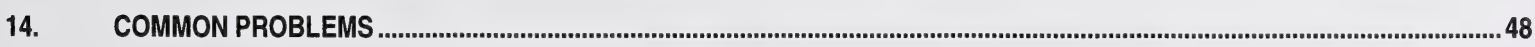

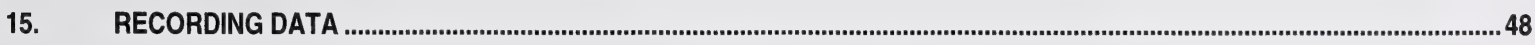

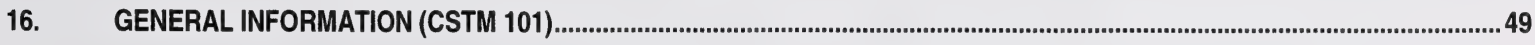

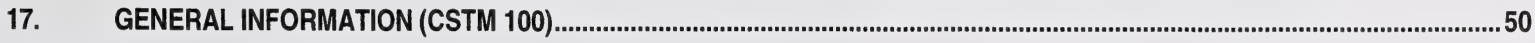

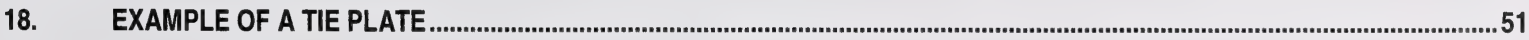




\section{SUGGESTED EQUIPMENT AND SUPPLIES}

\begin{tabular}{|l|l|l|}
\hline Accountable - Individual & \multicolumn{1}{|c|}{ Accountable - Crew } & \multicolumn{1}{|c|}{ Expendable } \\
\hline Clinometer & Staff compass & Spiral nails $(6.5 \mathrm{~cm})$ \\
\hline Surveyors hand compass & Axe & Blue tree marking paint \\
\hline Metal diameter tape & Cloth tape(s) (50m) & Plot posts-metal (corner, regen and sapling) \\
\hline Loggers tape & Photo holder & Pencils 2H and grease \\
\hline Topofil & Camera & Geo-flagging tape (orange, blue and yellow) \\
\hline Biltmore stick & Calipers (tree and seedling) & Aluminum tags-plot corner and tree \\
\hline Claw hammer & $\begin{array}{l}\text { Chainsaw, tool box, } \\
\text { stretcher and necessary } \\
\text { safety equipment }\end{array}$ & String \\
\hline 2 lb hammer & Canthook & Loggers crayon \\
\hline Hammer holder & Whistle & Field notebook \\
\hline Pocket calculator & $\begin{array}{l}\text { Tally Sheets (TM 267, TM } \\
\text { 249, Regen and Sectioning) }\end{array}$ & Paint pens/markers \\
\hline Douglas protractor & Cruisers Vest & Tie plates \\
\hline Hand lens & Hard Hat/with shield & \\
\hline Tallyboard (metal $8 \times 12)$ & ATV/snowmobile helmet & \\
\hline Pocket First Aid Kit & Trapper Nelson backpack & \\
\hline $\begin{array}{l}\text { Flare gun with flares and } \\
\text { bear bangers }\end{array}$ & Crayon holder & \\
\hline Bear repellent & Seedling calipers & \\
\hline Engineers scale $(15 \mathrm{~cm})$ & & \\
\hline & & \\
\hline
\end{tabular}

\section{PLOT TOPOGRAPHY}

\section{a. Location}

1.- Hollow For plots located in local topographic depressions - collecting water

2 - Flat For plots located on flat terrain - receiving water

3 - Slope For plots on mid and upper slopes - shedding water

4 - Hilltop For plots located on ridge crests - shedding water

\section{SOIL CODES}

\section{a. Erosion potential}

1 - Slight When 0 to $25 \%$ of the area is, or could be eroded in a flood situation.

2 - Moderate When $26 \%$ to $75 \%$ of the area is, or could be eroded in a flood situation.

3 - High When more than $75 \%$ of the area is, or could be eroded in a flood situation. 


\section{b. Drainage Codes}

\begin{tabular}{|c|c|}
\hline $1-$ Very rapidly drained & $\begin{array}{l}\text { Water is removed from the soil very rapidly relation to supply. Excess water flows } \\
\text { downward very rapidly if underlying material is permeable. There may be very rapid } \\
\text { subsurface flow during heavy rainfall provided there is a steep gradient. Soils have } \\
\text { very low available water storage capacity (usually less than } 2.5 \mathrm{~cm} \text { ) within the control } \\
\text { section and are usually coarse textured, or shallow, or both. Water source is } \\
\text { precipitation. }\end{array}$ \\
\hline 2 - Rapidly drained & $\begin{array}{l}\text { Water is removed from the soil rapidly in relation to supply. Excess water flows } \\
\text { downward if underlying material is permeable. Subsurface flow may occur on steep } \\
\text { gradients during heavy rainfall. Soils have low available water storage capacity (2.5- } \\
4 \mathrm{~cm} \text { ) within the control section, and are usually coarse textured, or shallow, or both. } \\
\text { Water source is precipitation. }\end{array}$ \\
\hline 3-Well Drained & $\begin{array}{l}\text { Water is removed from the soil readily but not rapidly. Excess water flows downward } \\
\text { readily into underlying permeable material or laterally as subsurface flow. Soils have } \\
\text { intermediate available water storage capacity }(4-5 \mathrm{~m}) \text { within the control section, and } \\
\text { are generally intermediate in texture and depth. Water source is precipitation. On } \\
\text { slopes subsurface flow may occur for short durations but additions are equalled by } \\
\text { losses. }\end{array}$ \\
\hline 4 - Moderately Well & $\begin{array}{l}\text { Drained Water is removed from the soil somewhat slowly in relation to supply. } \\
\text { Excess water is removed somewhat slowly due to low permeability, shallow water } \\
\text { table, lack of gradient, or some combination of these. Soils have intermediate to high } \\
\text { water storage capacity }(5-6 \mathrm{~cm}) \text { within the control section and are usually medium to } \\
\text { fine textured. Precipitation is the dominant water source in medium to fine textured } \\
\text { soils, precipitation and significant additions by subsurface flow are necessary in } \\
\text { coarse textured soils. }\end{array}$ \\
\hline 5 - Imperfectly Supply & $\begin{array}{l}\text { Drained Water is removed from the soil sufficiently slowly in relation to keep the soil } \\
\text { wet for a significant part of the growing season. Excess water moves slowly } \\
\text { downward if precipitation is major supply. If subsurface water or ground water, or } \\
\text { both, is main source, flow rate may vary but the soil remains wet for a significant part } \\
\text { of the growing season. Precipitation is main source if available water storage } \\
\text { capacity decreases. Soils have a wide range in available water supply, texture, and } \\
\text { depth, and are gleyed phases of well drained subgroups. }\end{array}$ \\
\hline 6 - Poorly drained & $\begin{array}{l}\text { Water is removed so slowly in relation to supply that the soil remains wet for a } \\
\text { comparatively large part of the time the soil is not frozen. Excess water is evident in } \\
\text { the soil for a large part of the time. Subsurface flow or ground water flow, or both, in } \\
\text { addition to precipitation are main water sources; there may also be a perched water } \\
\text { table, with precipitation exceeding evapotranspiration. Soils have a wide range in } \\
\text { available water storage capacity, texture, and depth and are gleyed subgroups, } \\
\text { Gleysols and Organic soils. }\end{array}$ \\
\hline 7 - Very poor drained & $\begin{array}{l}\text { Water is removed from the soil so slowly that the water table remains drained at or on } \\
\text { the surface for the greater part of the time the soil is not frozen. Excess water is } \\
\text { present in the soil for the greater part of the time. Ground water flow and subsurface } \\
\text { is less important except where there is a perched water table with precipitation } \\
\text { exceeding evapotranspiration. Soils have a wide range in available water storage } \\
\text { capacity, texture, and depth, and are either Gleysolic or Organic. }\end{array}$ \\
\hline
\end{tabular}




\section{TREE HEIGHT MEASUREMENT}

The height of a tree is defined as the length between the point of germination and the tip of the terminal leader. Heights are measured using a clinometer (with the percent scale) and a 30 or $50 \mathrm{~m}$ measuring tape. Tree height calculations must be completed on the reverse side of the PSP Tally Sheet (TM 249) (see Figure 4.2A). All data fields are required to be filled in except:

a) Only Slope distance and slope \% or horizontal distance is used.

b) Correction Factor is only used when the bottom \% reading is recorded at a different reference point other than the germination point. ie. $\mathrm{DBH}$ height $=1.3 \mathrm{~m}$

c) Check cruise height columns are not to be used by field crew members. This space is only filled in if there has been an actual check cruise completed.

It is very important that field crews understand the process of measuring height so that data is calculated correctly.

At a distance far enough away from the tree to keep the clinometer scale below $100 \%$, take readings for the top $\%$ of the tree (tip of the terminal leader), top \% to live crown, and the bottom \% of the tree (germination point) as shown in Figures 4.1. This may be difficult for deciduous trees as the top of the tree may not be visible through the crown. The slope of the ground must also be measured and recorded if it is greater than $10 \%$.

During remeasurement if the present height is shorter than the past height then a second height must be taken and recorded on the tally sheet directly below the previous measurement. It is advised that the horizontal distance be increased 5 to 10 meters before taking the second reading. It will be up to the cruisers discretion to decide which is the correct height data to be transferred to the front of the tally sheet. Put a line through the height information that is not used -never erase height information. On the front of the tally sheet record in comments HT to indicate that the height was double-checked in the field.

If live crown height is measured using a metric tape instead of the clinometer, record on the front of the PSP tally sheet (TM 249) in the comments section "height to L.C. measured directly" (Figure 2.14, tree \#10).

You should be approximately $25 \%$ further than previous height; ie. previous height is $20.2 \mathrm{~m}$, you should be 25.2 $\mathrm{m}, 36.0 \mathrm{~m}$ should be $43.0 \mathrm{~m}$

Also record the slope and slope distance or horizontal distance to the tree. To calculate the tree height, to the nearest $0.1 \mathrm{~m}$, use the following formula:

Slope Distance x Slope Correction Factor $x$

Top reading $\%$ - Bottom reading $\%$

$$
=\text { Tree Height }(\mathrm{m}) \quad \times 100 \%
$$

or

Horizontal Distance $\mathrm{x}$

Top reading $\%$ - Bottom reading $\%$ $100 \%$ $=$ Tree Height $(\mathrm{m})$ 
For example, is $22.8 \mathrm{~m}$ away on a slope of $15 \%$. The Suunto readings are $+80 \%$ and $+12 \%$.

Therefore, the tree is:

$22.8 \mathrm{~m} \times 0.989^{*} \times \quad \frac{+80-(+12)}{100} \quad=22.55 \times 0.68=15.33=15.3 \mathrm{~m}$

*Obtained from table in Section 4.5

$22.8 \times \quad \frac{+80-(+12)}{100} \quad=22.8 \times 0.68=15.5 \mathrm{~m}$

There are times when the germination point cannot be seen. In this situation, breast height is often used for the bottom \% reading and a correction factor of $1.3 \mathrm{~m}$ is added on the calculated total height.

Trees with a lean that require height measurement should have the slope readings taken from a location perpendicular to the lean as shown in Figure 4.2. This will prevent an erroneous measurement that could result in a shorter or taller tree because of the lean.

If at all possible, all height measurements should be taken perpendicular to the slope.

Common errors made during tree height calculations are:

1) Misreading \pm signs

- bottom \% readings may either read as positive or negative numbers. Bottom $\%$ reading are always subtracted from the top reading regardless on the \pm sign of the number.

ie: if the top $\%$ is +90 and bottom $\%$ is -3 then:

$$
\begin{gathered}
+90-(-3)=93 \\
\text { if the bottom } \% \text { reading was }+3 \text { then: } \\
+90-(+3)=87
\end{gathered}
$$

2) Not adding the appropriate correction factor, usually $1.3 \mathrm{~m}$ (breast height). Zero fill if the bottom reading is taken at the germination point, or put line through column.

a) adding the correction factor at the wrong time:

$$
\begin{aligned}
& \text { ie: } \begin{array}{ccc}
\text { top } \% & \text { bottom } \% & \begin{array}{c}
\text { Horizontal distance } \\
+90
\end{array}-3
\end{array} \\
& \begin{array}{c}
\text { Correction factor } \\
+1.3
\end{array} \\
& \text { Incorrect }([90-(-3)]+1.3) \times .20=18.86=18.9 \\
& \text { Correct }([90-(-3)] \times .20)+1.3=19.90=19.9
\end{aligned}
$$

3) Miscalculating total height through standard arithmetic errors. Refer to Appendix 4.10 .4 for rounding off procedures. 
4) Total height information recorded with no calculations.

All tree height calculations must be recorded for each sample tree in the space provided otherwise, the data will be considered invalid and deleted.

\begin{tabular}{|c|c|c|c|c|c|c|c|c|c|c|c|c|c|c|}
\hline $\begin{array}{c}\text { Tree } \\
\text { Number }\end{array}$ & Species & $\begin{array}{l}\text { Top } \\
\%\end{array}$ & $\begin{array}{l}\text { Top } \% \\
\text { to } \\
\text { Live } \\
\text { Crown }\end{array}$ & $\begin{array}{l}\text { Bottom } \\
\%\end{array}$ & $\begin{array}{l}\text { Not } \\
\text { to } \\
\text { Top } \\
\text { of } \\
\text { Tree }\end{array}$ & $\begin{array}{l}\text { Not to } \\
\text { Top of } \\
\text { Live } \\
\text { Crown }\end{array}$ & $\begin{array}{l}\text { Slope } \\
\text { Distance }\end{array}$ & $\begin{array}{l}\% \\
\text { Slope }\end{array}$ & $\begin{array}{l}\text { Horizontal } \\
\text { Distance }\end{array}$ & Correction & $\begin{array}{l}\text { Total } \\
\text { Height }\end{array}$ & $\begin{array}{l}\text { Height } \\
\text { to } \\
\text { Live } \\
\text { Crown }\end{array}$ & $\begin{array}{l}\text { Check } \\
\text { Cruise } \\
\text { Height }\end{array}$ & $\begin{array}{l}\text { Tree } \\
\text { Number }\end{array}$ \\
\hline 1 & SW & 92 & 33 & +3 & 89 & 30 & - & - & 20.0 & +1.3 & 19.1 & 7.3 & & 1 \\
\hline & & & & & & & & & & & & & & \\
\hline 4 & SW & 84 & 60 & -1 & 85 & 61 & 22.0 & 13 & 21.8 & - & 18.4 & 13.3 & & 4 \\
\hline 7 & SW & 98 & 28 & 0 & 98 & 28 & - & - & 24.0 & +1.3 & 24.8 & 8.0 & & 7 \\
\hline 10 & SW & 64 & 10 & -2 & 66 & 12 & - & - & 20.0 & +1.3 & 14.5 & 3.7 & & 10 \\
\hline 13 & AW & 73 & 63 & +1 & 72 & 62 & - & - & 21.0 & - & 15.1 & 13.0 & & 13 \\
\hline 16 & PB & 99 & 80 & 0 & 99 & 80 & - & - & 25.0 & +1.3 & 26.0 & 21.3 & & 16 \\
\hline
\end{tabular}

\section{a. Determining Tree Height with a Laser Clinometer or Haglof Vertex}

Before using the electronic instrument, be sure that you are familiar with the operators manual and the operation of the tool.

Only total tree height and height to live crown is recorded on the tree tally sheet. Indicate on the back of the sheet which tool was used.

The operator must have the blue direction dot in sight and double check the height of the tree if it does not grow or the height remains the same. Record both sets of numbers on the back of the tally sheets.

\section{SLOPE CORRECTION FACTORS AND TABLES}

To convert slope distance (S.D.) horizontal distance (H.D.)

$$
\text { H.D. }=\text { S. D. } x \text { slope distance factor }
$$

To convert horizontal distance (H.D. to slope distance (S. D.)

$$
\text { S. D. }=\frac{H . D .}{\text { slope distance factor }}
$$




\section{SLOPE DISTANCE FACTORS}

\begin{tabular}{|c|c|c|c|c|c|}
\hline$\%$ Slope & & $\%$ Slope & & \% Slope & \\
\hline 10 & 0.995 & 40 & 0.928 & 71 & 0.819 \\
\hline 11 & 0.994 & 41 & 0.925 & 71 & 0.815 \\
\hline 12 & 0.993 & 42 & 0.922 & 72 & 0.812 \\
\hline 13 & 0.992 & 43 & 0.919 & 73 & 0.808 \\
\hline 14 & 0.990 & 44 & 0.915 & 74 & 0.804 \\
\hline 15 & 0.989 & 45 & 0.912 & 75 & 0.800 \\
\hline 16 & 0.987 & 46 & 0.908 & 76 & 0.796 \\
\hline 17 & 0.986 & 47 & 0.905 & 77 & 0.792 \\
\hline 18 & 0.984 & 48 & 0.902 & 78 & 0.789 \\
\hline 19 & 0.982 & 49 & 0.898 & 79 & 0.785 \\
\hline 20 & 0.980 & 50 & 0.894 & 80 & 0.781 \\
\hline 21 & 0.979 & 51 & 0.891 & 81 & 0.777 \\
\hline 22 & 0.977 & 52 & 0.887 & 82 & 0.773 \\
\hline 23 & 0.974 & 53 & 0.883 & 83 & 0.769 \\
\hline 24 & 0.972 & 54 & 0.880 & 84 & 0.766 \\
\hline 25 & 0.970 & 55 & 0.876 & 85 & 0.762 \\
\hline 26 & 0.968 & 56 & 0.872 & 86 & 0.758 \\
\hline 27 & 0.965 & 57 & 0.869 & 87 & 0754 \\
\hline 28 & 0.963 & 58 & 0.865 & 88 & 0.751 \\
\hline 29 & 0.960 & 59 & 0.861 & 89 & 0.747 \\
\hline 30 & 0.958 & 60 & 0.857 & 90 & 0.743 \\
\hline 31 & 0.955 & 61 & 0.854 & 91 & 0.740 \\
\hline 32 & 0.952 & 62 & 0.850 & 92 & 0.736 \\
\hline 33 & 0.950 & 63 & 0.846 & 93 & 0.732 \\
\hline 34 & 0.947 & 64 & 0.842 & 94 & 0.729 \\
\hline 35 & 0.944 & 65 & 0.838 & 95 & 0.725 \\
\hline 36 & 0.941 & 66 & 0.835 & 96 & 0.721 \\
\hline 37 & 0.938 & 67 & 0.831 & 97 & 0.718 \\
\hline 38 & 0.935 & 68 & 0.827 & 98 & 0.714 \\
\hline 39 & 0.932 & 69 & 0.823 & 99 & 0.711 \\
\hline
\end{tabular}

\section{USE AND CONSTRUCTION OF A BILTMORE STICK}

Biltmore Sticks are used to measure diameter of saplings or tagged stems $<9.1 \mathrm{~cm}$ as measuring a stem with a small diameter often results in a broken diameter tape. To use a Biltmore Stick, align " 0 " on one side of the stem, at breast height, and read the diameter on the other keeping the focal length at $64 \mathrm{~cm}$ (metric equivalent of $25 \mathrm{in}$ 1). The following table shows the straight line distance from "0", to be marked on the stick, associated with the corresponding diameter (in centimeters).

\footnotetext{
${ }^{1}$ Avery, T.E. and H. E. Burkharl. 1983. Forest Measurements. $3^{\text {rd }}$ ed. McGraw-Hill Inc., New York, N.Y. pp. 68-69
} 


\begin{tabular}{|c|c|c|c|}
\hline DBH & Biltmore & DBH & Biltmore \\
\hline 1.0 & 0.99 & 5.2 & 5.00 \\
\hline 1.2 & 1.19 & 5.4 & 5.19 \\
\hline 1.4 & 1.38 & 5.6 & 5.37 \\
\hline 1.6 & 1.58 & 5.8 & 5.55 \\
\hline 1.8 & 1.77 & 6.0 & 5.74 \\
\hline 2.0 & 1.97 & 6.2 & 5.92 \\
\hline 2.2 & 2.16 & 6.4 & 6.10 \\
\hline 2.4 & 2.36 & 6.6 & 6.28 \\
\hline 2.6 & 2.55 & 6.8 & 6.46 \\
\hline 2.8 & 2.74 & 7.0 & 6.65 \\
\hline 3.0 & 2.93 & 7.2 & 6.83 \\
\hline 3.2 & 3.12 & 7.4 & 7.01 \\
\hline 3.4 & 3.31 & 7.6 & 7.18 \\
\hline 3.6 & 3.50 & 7.8 & 7.36 \\
\hline 3.8 & 3.69 & 8.0 & 7.54 \\
\hline 4.0 & 3.88 & 8.2 & 7.72 \\
\hline 4.2 & 4.07 & 8.4 & 7.90 \\
\hline 4.4 & 4.26 & 8.6 & 8.07 \\
\hline 4.6 & 4.44 & 8.8 & 8.29 \\
\hline 4.8 & 4.63 & 9.0 & 8.43 \\
\hline 5.0 & 4.81 & & \\
\hline
\end{tabular}

\section{ACCESS EVALUATION CODES}

\begin{tabular}{|c|c|}
\hline 1. All Weather Road & $\begin{array}{l}\text { All roads in this category are paved or are well traveled gravel roads. These } \\
\text { roads are well drained with little possibility of washing out or flooding in heavy } \\
\text { rain situations. In the winter, these roads are plowed on a regular basis. }\end{array}$ \\
\hline 2. Dry Weather Road & $\begin{array}{l}\text { This type of road tends to be quite slippery in the spring and fall and becomes } \\
\text { heavily rutted when wet. The shoulder on these roads are generally quite soft } \\
\text { most of the year. Slopes on these roads should not exceed } 10 \% \text { as they are } \\
\text { difficult to drive up or down when wet, even in a four wheel drive vehicle. } \\
\text { Minor flooding or washouts can occur but the roads can still be traveled in a } \\
\text { four wheel drive vehicle as the roads have solid bottoms. }\end{array}$ \\
\hline 3. Deteriorating Road & $\begin{array}{l}\text { These roads are not used very often and are starting to grow over with grass, } \\
\text { small shrubs, or small trees. During heavy rains they can be easily washed } \\
\text { out or heavily rutted. It may be very difficult to travel on these roads even with } \\
\text { a four wheel drive and the use of an all terrain vehicle should be considered. }\end{array}$ \\
\hline 4. All Terrain Vehicles only & $\begin{array}{l}\text { Included in this category are seismic lines, old trails, and any roads } \\
\text { inaccessible using a four wheel drive vehicle. If a plot is more than } 1000 \mathrm{~m} \\
\text { along a seismic line or trail, this access is to be indicated. If the distance is } \\
\text { less than this, the remeasurement crew can walk to the plot. }\end{array}$ \\
\hline 5. Helicopter Access. & $\begin{array}{l}\text { This access codes should be used only when there is no other way into the } \\
\text { plot (i.e. cannot cross river, too far off roads to feasibly drive all terrain vehicle } \\
\text { to etc.) It is important to remember to have a suitable location for a helicopter } \\
\text { to land and take of from. Keep in mind that openings used for a landing may } \\
\text { grow over within } 10 \text { years presenting a helicopter to land in the future }\end{array}$ \\
\hline 6. Unknown & $\begin{array}{l}\text { This code is for office use only and is used when access has not been verified } \\
\text { and maps do not provide any assistance. }\end{array}$ \\
\hline
\end{tabular}




\section{LEGAL SURVEY SYSTEM OF ALBERTA}

The province of Alberta has been surveyed using a system based on a grid framework. The largest divisions in this system are called meridians. In Alberta there are meridians numbered 4, 5 and 6 . The fourth meridian, as shown in Figure 4.19 corresponds to the Alberta Saskatchewan border.

Each meridian has been divided into parcels of land, called townships, 36 square miles (93.2 square kilometers) in size. At six mile (9.654 kilometres) intervals, in a north-south direction, are divisions also called townships and are numbered 1 to 126 starting from the United States border and extending to the Northwest Territories border. The east-west six mile intervals are called "ranges" and are numbered westward from each meridian. The numbering of townships begin in the southeast corner of the province. An example of locating any given township is shown in Figure 4.19.

The grid system is further refined by taking each township and dividing it into 36 -one square mile (1.604 square kilometers) parcels of land called "sections". The numbering scheme for each township is shown in Figure 4.19.

The last division in the survey system takes each section and divides it into 16 equal parts called "legal subdivisions" (LSD's). The numbering scheme of each section is demonstrated in Figure 4.19.

If a PSP was located using the example in Figure 4.19, the legal land description would be recorded as 13-1-8718-4. This translates to Legal Subdivision 13 of Section 1 in Township 87, Range 18, West of the Fourth Meridian. If a PSP is located in two or more sections/legal subs, all legal descriptions are tallied and the location of plot enter is noted, i.e. if a PSP was located at the cross section of legal subs $11,12,13$, and 14 then the following information would be tallied.

Recorded on Maintenance Sheet as:

$11-1-87-18-4$

$12-1-87-18-4$

13-1-87-18-4.1 (this would be recorded as the correct legal descriptions)

14-1-87-18-4

The center of the PSP falls in L.S. 13-recorded on the PSP Header Sheet (TM 267) during establishment remeasurement.

\section{FIELD SHEET HANDBOOK}

\section{a. Tally Sheet Instructions}

The PSP field handbook contains instructions pertaining to data entry on the tally sheet, a summary of allowable errors, and a plot measurement summary.

\section{b. General Information (Columns 1 - 37)}

This information is recorded on the Header Sheet and every Tally Sheet.

\section{Column 1-2}


Agency: numeric, right justified, zero filled. As listed on the Agency list.

\section{Column 3-12}

Group Number: numeric, right justified, zero filled.

e.g.

$$
\begin{array}{|l|l|l|}
\hline 0 & 2 & 0 \\
\hline
\end{array}
$$

\section{Column 13}

Sub Plot Number: numeric $(1,2,3,4)$

e.g.

$$
1 \text { = sub plot } 1
$$

\section{Column 14-15}

Measurement Number: numeric, ' 00 ' for an establishment plot, subsequent measurements would be $01,02,03$, etc.

e.g.

$$
\begin{array}{|l|l|}
\hline 0 & 3 \\
\hline
\end{array}=3^{\text {rd }} \text { measurement }
$$

\section{Column 16-18}

Year: numeric; 1961

e.g

\begin{tabular}{|l|l|l|l|}
\hline 1 & 9 & 6 & 1 \\
\hline
\end{tabular}

\section{Column 20-21}

Month: numeric, right justified, May=05, June $=06$, etc., zero filled.

e.g.

$$
\begin{array}{|l|l|}
\hline 0 & 6 \\
\hline
\end{array}
$$

\section{Column 22-23}

Day: numeric, right justified, zero filled.

e.g.

$$
\begin{array}{|l|l|}
\hline 0 & 3 \\
\hline
\end{array}=3^{\text {rd }} \text { day }
$$

\section{Column 24-25}

L.S.: (Legal Subdivision), numeric, right justified, zero filled, only use if known. e.g.

$$
\begin{array}{|l|l|}
\hline 1 & 3 \\
\hline
\end{array} \text { = Legal subdivision } 13
$$

\section{Column 26-27}

Section: numeric, right justified, zero filled. 
e.g.

\begin{tabular}{|l|l|}
\hline 0 & 2 \\
\hline
\end{tabular}

\section{Column 28-30}

Twp.: (Township), numeric, right justified, zero filled.

e.g.

$$
\begin{array}{|l|l|l|}
\hline 0 & 3 & 2 \\
\hline
\end{array}
$$

\section{Column 31-32}

Rge.: (Range), numeric, right justified, zero filled.

e.g.

$$
\begin{array}{|l|l|}
\hline 0 & 3 \\
\hline
\end{array}
$$

\section{Column 33}

M.: (Meridian), numeric.

e.g.

$$
5=\text { West of the } 5^{\text {th }} \text { meridian }
$$

\section{Column 34-36}

Plot Type: Numeric, and left justified. First column is primary description. The remaining two columns are not defined yet; zero fill until further notice.

e.g.

$$
\begin{array}{|l|l|l|}
\hline 3 & 0 & 0 \\
\hline
\end{array}
$$

e.g.

$$
\begin{array}{|l|l|l|}
\hline 0 & 0 & 0 \\
\hline
\end{array}
$$

\section{Code}

$$
\begin{array}{ll}
0 & =\text { No treatment } \\
1 & =\text { Growth Intercept Plot } \\
2 & =\text { Fertilized } \\
3 & =\text { Thinned } \\
4 & =\text { Drained } \\
5 & =\text { Burned } \\
6 & =\text { Mistletoe } \\
7 & =\text { Immature (16-55 years) } \\
8 & =\text { Paired Plot } \\
9 & =\text { University of Alberta Plot }
\end{array}
$$

\section{Column 37}

Imp.: (Imperial), " $X$ " if information is collected in imperial units; blank if collected in metric. 
e.g.

$\mathrm{X}=$ Indicates measurements done in imperial units.

\section{c. Record 01 - Header Information (Columns 38-212)}

\section{Column 38-39}

Record Type: previously filled as 01

\section{Column 40-60}

Plot Sizes (Tree, Sapling and Regen): numeric, recorded in square metres right justified. Plot sizes are determined in the office using the horizontal distances recorded on the plot maintenance form.

e.g.

\begin{tabular}{|l|l|l|l|l|l|l|}
\hline & & 1 & 0 & 0 & 0 & .0 \\
\hline
\end{tabular}

\section{Column $61-71$}

Phase 1, 2 or 3 Overstorey - See PSP Header information for description.

\section{Column $72-93$}

AVI Interpreted Overstorey: numeric and alpha using AVI ecological moisture regime, crown closure class, height and tree species composition.

Ecological moisture regime can be numeric or character. Small cap letter goes in column 72 . If using numeric label this goes in column 73. Do not input both. Only one entry needed.

\section{Ecological Moisture Regime Labels}

\begin{tabular}{|l|c|l|}
\hline \multicolumn{1}{|c|}{$\begin{array}{c}\text { Moisture } \\
\text { Regime }\end{array}$} & $\begin{array}{c}\text { Database } \\
\text { Numeric } \\
\text { Label }\end{array}$ & \multicolumn{1}{|c|}{$\begin{array}{c}\text { Database } \\
\text { Character Label }\end{array}$} \\
\hline Very xeric & 0 & $\mathrm{~d}$-dry \\
\hline Xeric & 1 & $\mathrm{~d}$-dry \\
\hline Subzeric & 2 & $\mathrm{~d}$-dry \\
\hline Submesic & 3 & $\mathrm{~m}$-mesic (default) \\
\hline Mesic & 4 & $\mathrm{~m}$-mesic (default) \\
\hline Subhygric & 5 & $\mathrm{~m}$-mesic (default) \\
\hline Hygric & 6 & w-wet \\
\hline Subhygric & 7 & w-wet \\
\hline Hygric & 8 & $\mathrm{a}-$ aquatic \\
\hline
\end{tabular}

Crown closure class can be numeric or character. Capital letter goes in column 74 . If using numeric, label goes in column 75 . Do not use both. Only one entry needed.

\section{Crown Closure Class Labels}

\begin{tabular}{|l|l|l|}
\hline Crown Closure & Database & Database \\
\hline
\end{tabular}




\begin{tabular}{|c|c|c|}
\hline Class (\%) & Numeric Label & Character Label \\
\hline $01-05$ & & V \\
\hline $06-10$ & 0 & $\mathrm{~A}$ \\
\hline $11-20$ & 1 & $\mathrm{~A}$ \\
\hline $21-30$ & 2 & $\mathrm{~A}$ \\
\hline $31-40$ & 3 & $\mathrm{~B}$ \\
\hline $41-50$ & 4 & $\mathrm{~B}$ \\
\hline $51-60$ & 5 & $\mathrm{C}$ \\
\hline $61-70$ & 6 & $\mathrm{C}$ \\
\hline $71-80$ & 7 & $\mathrm{D}$ \\
\hline $81-90$ & 8 & $\mathrm{D}$ \\
\hline $91-100$ & 9 & $\mathrm{D}$ \\
\hline
\end{tabular}

Height is recorded to the closest metre and is numeric and goes in columns 76 and 77 . Input as 2 digits i.e.: $9 m=09$.

Tree species composition is recorded in $10 \%$ classes and must add up to $100 \%$. A maximum of 5 species. First letter is capitalized and second letter is small.

Species 1 (Alpha) in Columns 78-79

Species $1 \%$ in Columns $80-81$

Species 2 (Alpha) in Columns 82-83

Species $2 \%$ in Columns 84

Species 3 (Alpha) in Columns 85-86

Species $3 \%$ in Columns 87

Species 4 (Alpha) in Columns 88-89

Species $4 \%$ in Columns 90

Species 5 (Alpha) in Columns 91-92

Species $5 \%$ in Columns 93

e.g.

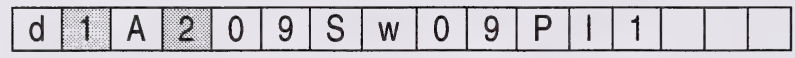

Column 37

Imp: (Imperial), " $X$ " if information is collected in imperial units; blank if collected in metric.

e.g.

$\mathrm{X}$ = indicates measurement done in imperial units.

\section{Column 94-108}

Phase 1, 2 or 3 Understorey - See PSP Header information for description.

Column 109-128

AVI Interpreted Understorey: numeric and alpha using AVI crown closure class, height and tree species compositions.

Crown closure class can be numeric or a character. Capital letter goes in column 109. If using numeric, label goes in column 110. Do not use both. Only one entry needed. 
Height is recorded to the closest metre and is numeric and goes in columns 111 and 112 . Input as 2 digits i.e.: $9 m=09$.

Tree species composition is recorded in $10 \%$ classes and must add up to $100 \%$. A maximum of 5 species.

First letter is capitalized and second letter is small.

Species 1 (Alpha) in Columns 113-114

Species $1 \%$ in Columns $115-116$

Species 2 (Alpha) in Columns 117-118

Species $2 \%$ in Columns 119

Species 3 (Alpha) in Columns 120-121

Species $3 \%$ in Columns 122

Species 4 (Alpha) in Columns 123-124

Species $4 \%$ in Columns 125

Species 5 (Alpha) in Columns 126-127

Species $5 \%$ in Columns 128

e.g.

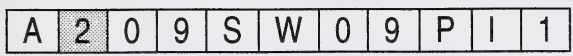

\section{Column 129}

Location: numeric

\section{Code}

1 = hollow

2 = flat

$3=$ slope

$4=$ hilltop

e.g.

3 = plot location on a slope

\section{Column 130-132}

$\%$ slope: average percent slope for the plot, numeric characters, right justified.

e.g.

$$
\begin{array}{|l|l|l|}
\hline 0 & 1 & 5 \\
\hline
\end{array}
$$

\section{Column 133-134}

Aspect: alpha characters, right justified

\section{Code}

$\mathrm{N}=$ North 


$$
\begin{array}{ll}
\mathrm{S} & =\text { South } \\
\mathrm{E} & =\text { East } \\
\mathrm{W} & =\text { West } \\
\mathrm{NE} & =\text { Northeast } \\
\mathrm{NW} & =\text { Northwest } \\
\mathrm{SE} & =\text { Southeast } \\
\mathrm{SW} & =\text { Southwest } \\
\mathrm{NA} & =\text { Non Applicable }(\text { Slope }=0 ")
\end{array}
$$

e.g.

$$
\begin{array}{|l|l|}
\hline & \mathrm{N} \\
\hline
\end{array}
$$

\section{Column 135-138}

Elevation: elevations in metres, numeric characters, right justified (convert feet to metres by multiplying by .3048).

e.g.

\begin{tabular}{|l|l|l|l|}
\hline 1 & 0 & 9 & 7 \\
\hline
\end{tabular}

\section{Column 139}

Erosion Potential: numeric. This describes the chance of water eroding down to or into the mineral soil layer and is based upon water flow, slope and soil type.

\section{Code}

1 = Slight - when 0 to $25 \%$ of the area is, or could be eroded in a flood situation.

$2=$ Moderate - when $25 \%$ to $75 \%$ of the area is, or could be eroded in a flood situation.

$3=$ High - when more than $75 \&$ of the area is, or could be eroded in a flood situation.

e.g.

$$
2 \text { = moderate erosion potential }
$$

\section{Column 140}

Drainage: numeric, for definitions of codes see Appendix 4.3 of the PSP Manual

\section{Code}

$$
\begin{aligned}
& 1=\text { Very rapidly drained } \\
& 2 \text { = Rapidly drained } \\
& 3=\text { Well drained } \\
& 4=\text { Moderately well drained } \\
& 5=\text { Imperfectly drained } \\
& 6=\text { Poorly drained } \\
& 7=\text { Very poorly drained }
\end{aligned}
$$


e.g. $\quad 6=$ poorly drained soil

\section{Column 141-142}

Depth to Mineral Soil: numeric, right justified, measured in $\mathrm{cm}$ or inches.

If greater than $99 \mathrm{~cm}$, fill with 99 . This will indicate a depth to mineral soil of 99 or greater.

e.g.

$$
\begin{array}{|l|l|}
\hline 1 & 0 \\
\hline
\end{array}=10 \mathrm{~cm}
$$

\section{Column 143}

Surface Vegetation-Type: numeric, nine possible types or combinations of grass, lichen/=moss, herbs (flowers and non-woody stems) and shrubs (woody stems). The dominant type is recorded.

\section{Code}

$1=$ grass

$2=$ grass + herbs

$3=$ grass + shrubs

$4=$ lichen $/$ moss

$5=$ lichen/moss + herbs

$6=$ lichen/moss + shrubs

$7=$ herbs

$8=$ herbs + shrubs

$9=$ shrubs

e.g.

4 = lichen/moss

\section{Column 144-146}

Surface Vegetation - \% Ground Cover: numeric, right justified. Tally the percent of ground that is covered by surface vegetation type.

e.g.

\begin{tabular}{|l|l|l|}
\hline & 9 & 5 \\
\hline
\end{tabular}$=95 \%$ of ground covered by surface vegetation type

\section{Column 147}

Maintenance Report - Access: numeric (for definitions of Access codes see Appendix 4.8).

\section{Code}

1 = all weather road

2 = dry weather road

$3=$ deteriorating road

$4=$ all terrain vehicle

$5=$ helicopter

6 = unknown 


\section{Column 148}

Plot Damage: numeric

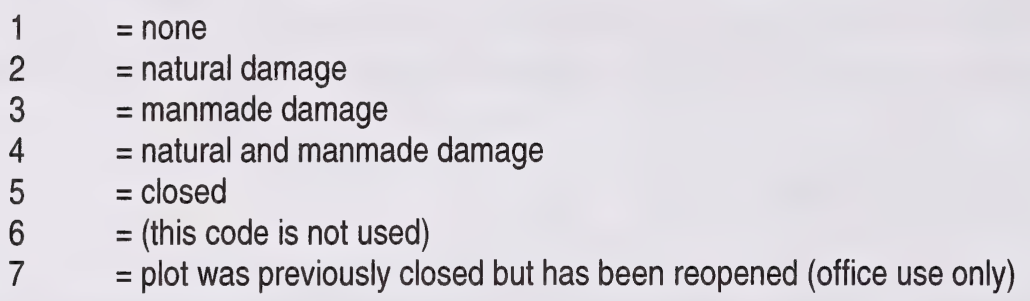

\section{Column 149}

Buffer Damage: numeric

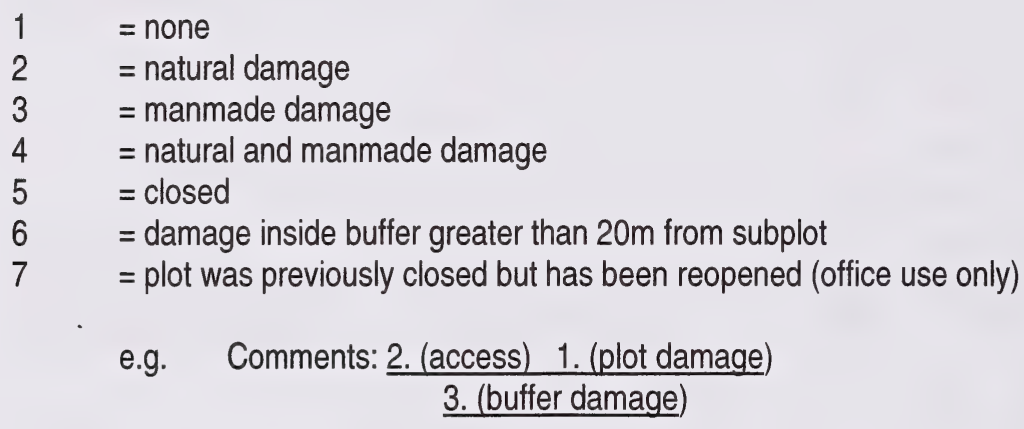

= dry weather road, none, manmade damage

\section{Column 150-153}

Establishment Year: numeric

e.g.

\begin{tabular}{|l|l|l|l|}
\hline 1 & 9 & 6 & 1 \\
\hline
\end{tabular}

\section{Column 164}

Plot Configuration

\section{Column 180-183}

Stand Origin

\section{Column 184}

Site Index/TPR: character

\section{Column 185-186}

Site Index/TPR: numeric

\section{Column 187-190}

Photo year 
Column 191-198

Ecosite

Column 199-201

Aspect in Degrees

Column 202

Nutrient Regime

Column 203-204

Natural Region

Column 203-208

Minimum diameter Measured ( $\mathrm{mm}$ )

\section{Column 209-210}

Stump Height $(\mathrm{cm})$

\section{Column 211}

Surface Expression

\section{Column 212}

Slope Position
d. Record 02 - Tree Information - header Sheet (Columns 1-37) - Tally Sheet (Columns 38-124)

\section{Column 38-39}

Record type: previously filled as 02

\section{Column 40-43}

Tree Number: numeric, right justified.

Tree numbers will be:

1. Consecutive i.e. 1 through 9997 (saplings included).

2. 0000 - representing a tree felled outside the plot to determine stump age and increments (pre-filled on Header Sheet).

e.g.

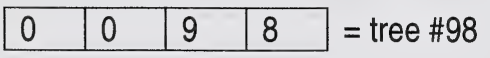

\section{Column 44-45}

Species: tree species, alpha characters

\section{Code}

$\mathrm{FA} \quad=$ Alpine fir 


$$
\begin{array}{ll}
\text { FB } & =\text { Balsam fir } \\
\text { FD } & =\text { Douglas fir } \\
\text { LA } & \text { = Alpine larch } \\
\text { LT } & =\text { Tamarack } \\
\text { LW } & =\text { Western larch } \\
\text { PF } & \text { L Limber pine } \\
\text { PJ } & =\text { Jack pine } \\
\text { PL } & =\text { Lodgepole pine } \\
\text { PW } & =\text { Whitebark pine } \\
\text { SB } & \text { Black spruce } \\
\text { SE } & =\text { Englemann spruce } \\
\text { SW } & =\text { White spruce } \\
\text { AW } & \text { Aspen } \\
\text { PB } & =\text { Balsam poplar } \\
\text { BW } & =\text { White birch } \\
\text { NO } & =\text { Indicates No trees to tally in regeneration plot }
\end{array}
$$

e.g.

$$
\begin{array}{|l|l|}
\hline A & W \\
\hline
\end{array}
$$

\section{Column 46-49}

DBH: (Diameter at Breast Height), one decimal place, numeric, right justified. In the computer the format is in millimeters (No Decimal).

e.g.

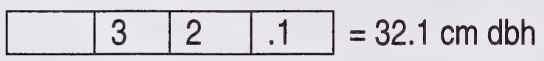

\section{Column 50-53}

Height: (Tree Height), one decimal place, numeric, right justified. In the computer the format is in decimeters (No Decimal).

e.g.

$$
\begin{array}{|l|l|l|}
\hline 3 & 0 & .6 \\
\hline
\end{array}=30.6 \mathrm{~m} \text { tree height }
$$

\section{Column 54-57}

Height to Live Crown: (Tree Height from base to point of first branch of the crown), one decimal place, numeric, right justified. In the computer the format is in decimeters (No Decimal).

e.g.

\begin{tabular}{|l|l|l|l|}
\hline & 1 & 0 & .5 \\
\hline
\end{tabular}

\section{Column 58}

C.C. (Crown Class), alpha character

\section{Code}

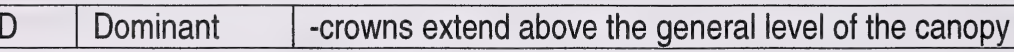




\begin{tabular}{|c|l|l|}
\hline C & Codominant & -crowns form the general level of the canopy \\
\hline I & Intermediate & $\begin{array}{l}\text {-crowns below but extending into the bottom of the general level of the } \\
\text { canopy }\end{array}$ \\
\hline S & Suppressed & - crowns entirely below the general level of the canopy \\
\hline O & Open-grown & -if the trees branches does not interact with another trees branches. \\
\hline
\end{tabular}

e.g. $\quad S=$ suppressed tree

\section{Column 59-64}

Condition Codes: (Tree condition codes) numeric. If the tree has no defect, record 00. Zero filling is not required. See Master Condition Code List

e.g.

\begin{tabular}{|l|l|l|l|l|l|}
\hline 5 & 1 & 5 & 4 & & \\
\hline
\end{tabular}

e.g.

\begin{tabular}{|l|l|l|l|l|l|}
\hline 2 & 9 & & & & \\
\hline
\end{tabular}

e.g.

\begin{tabular}{|l|l|l|l|l|l|}
\hline 6 & 3 & 5 & 6 & 6 & 6 \\
\hline
\end{tabular}

If there is not visible defect, a condition code 00 is recorded.

The following columns 65-76 are on Header Sheet only (TM 267)

\section{Column 65-67}

DBH Age: (Tree DBH age), numeric characters, right justified, zero filled

e.g.

$$
\begin{array}{|l|l|l|}
\hline 1 & 1 & 6 \\
\hline
\end{array}
$$

\section{Column 68-70}

Stump Age: (Tree stump age), numeric characters, right justified, zero filled.

e.g.

$$
\begin{array}{|l|l|l|}
\hline 1 & 2 & 1 \\
\hline
\end{array}
$$

\section{Column $71-76$}

Stump Increment Width: increment width for the last 20 yrs. growth done in 2 measurements: $0-10 \mathrm{yrs}$, 11-20 yrs, numeric characters, right justified, one decimal place, zero filled. Entered as $\mathrm{mm}$ in digital file.

e.g.

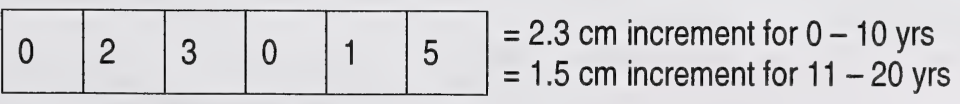

\section{Column $77-79$}

Azimuth: azimuth of tree from plot center, numeric, right justified, 1 to $360^{\circ}$ 
e.g.

\begin{tabular}{|l|l|l|}
\hline 0 & 2 & 0 \\
\hline
\end{tabular}$=20^{\circ}$ from the plot centre

\section{Column 80-82}

Distance: distance of tree from plot center, numeric, right justified one decimal place. In the computer, the format is in decimeters (No Decimal).

e.g

\begin{tabular}{|l|l|l|}
\hline 0 & 6 & .3 \\
\hline
\end{tabular}$=6.3 \mathrm{~m}$ from plot center

\section{Column 83-89}

Tree Plot size $\left(\mathrm{m}^{2}\right)$ : numeric, right justified, go to one decimal place. Zero filled.

Tree Plot Size $\left(m^{2}\right)$ : numeric, right justified, go to one decimal place. Zero filled.

\section{Column 97-103}

Regen Plot Size $\left(\mathrm{m}^{2}\right)$

\section{Column 104-107}

Establishment Year: numeric, right justified.

\section{Column 108}

Crown Status: " $Y$ " indicates tree needs crown measurements. "Blank" indicates no crown measurement required.

\section{Column 109-112}

Crown Width North: recorded in decimeters (dm). Right justified.

\section{Column 113-116}

Crown Width West: recorded in decimeters (dm). Right justified.

\section{Column 117-120}

Crown Width West: recorded in decimeters (dm). Right justified.

Column 121-124

Crown Width East: recorded in decimeters (dm). Right justified.

\section{e. Record 03 - Regen Information (Columns 38-85)}

\section{Column 38-39}

Record Type: previously recorded as 03 .

\section{Column 40-43}

Tree number: previously recorded as 9998.

\section{Column 44-45}

Species: tree species, alpha characters. 
Column 40-48, 49-51, 52-54, 55-57, 58-60

Total (1-5): numeric, right justified, zero filled. Add in 3 plot sizes and establishment year from Page 41: numeric right justified, zero filled.

e.g.

\begin{tabular}{|l|l|l|}
\hline 0 & 0 & 2 \\
\hline
\end{tabular}$=2$ regeneration of that species in that height class

\section{Column 61-67}

Tree Plot Size $\left(\mathrm{m}^{2}\right)$ : right justified.

e.g.

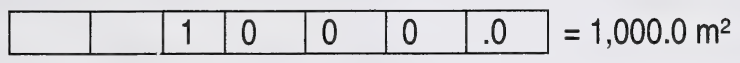

\section{Column 68-74}

Sapling Plot Size $\left(\mathrm{m}^{2}\right)$ : right justified.

e.g.

\begin{tabular}{|l|l|l|l|l|l|l|}
\hline & & & 2 & 5 & 0 & .0 \\
\hline
\end{tabular}

\section{Column 75-81}

Regen Plot Size $\left(\mathrm{m}^{2}\right)$ : right justified.

e.g.

\begin{tabular}{|l|l|l|l|l|l|l|}
\hline & & & & 6 & 2 & .0 \\
\hline
\end{tabular}

\section{Column 81-85}

Establishment Year: right justified.

e.g.

\begin{tabular}{|l|l|l|l|}
\hline 1 & 9 & 6 & 0 \\
\hline
\end{tabular}

\section{f. Summary of Allowable Errors}

\begin{tabular}{|l|l|}
\hline \multicolumn{1}{|c|}{ Item } & \multicolumn{1}{c|}{ Allowable Error } \\
\hline $\begin{array}{l}\text { Location of Plot Centre } \\
\text { (Tie Point and Tie Line) }\end{array}$ & $-2 \%$ of the cruise line horizontal distance (e.g. \\
& $3 \mathrm{~m}$ of a $150 \mathrm{~m}$ tie line H.D.) \\
\hline & \\
\hline Plot Size (Sides) - Tree Plot & $-31.62 \pm .25 \mathrm{~m}(31.37-31.87 \mathrm{~m})$ \\
\hline & $38.73 \pm .31 \mathrm{~m}(38.72-39.04 \mathrm{~m})$ \\
\hline & $44.72 \pm 0.36 \mathrm{~m}(44.36-45.08 \mathrm{~m})$ \\
\hline - Sapling/Regen Plot & $-7.90 \pm .06 \mathrm{~m}(7.84-7.96 \mathrm{~m})$ \\
\hline & $9.69 \pm .08 \mathrm{~m}(9.61-9.77 \mathrm{~m})$ \\
\hline & $11.09 \pm .09 \mathrm{~m}(11.09-11.27 \mathrm{~m})$ \\
\hline & \\
\hline & \\
\hline
\end{tabular}




\begin{tabular}{|c|c|}
\hline Plot Size (bearings) & $\pm 2^{\circ}$ \\
\hline No. of Trees Tallied and Species Identified & Tree plot - none \\
\hline & $\begin{array}{l}\text { Sapling plot - } \pm 5 \% \text { of total (e.g. 2- saplings } \pm 1 \text { ) - } \\
\text { no allowable error in identification }\end{array}$ \\
\hline & Regen plot $- \pm 10 \%$ (e.g. 20 regen \pm 2 ) \\
\hline DBH & $\begin{array}{l}\text { Diameter Breast height }-1.3 \mathrm{~m} \pm 6.5 \mathrm{~cm}( \pm 5 \%) \\
\text { diameter } - \pm 1.0 \mathrm{~cm}\end{array}$ \\
\hline Height and Height to Live Crown & $\pm 3 \%$ (e.g. $16.2 \mathrm{~m} \pm .5 \mathrm{~m})$ \\
\hline Crown Class and Condition Codes & $\begin{array}{l}10 \% \text { of stems tallied may have incorrect crown } \\
\text { class or condition codes (e.g. } 10 \text { trees of } 100 \\
\text { tallied) }\end{array}$ \\
\hline Stem Mapping & Azimuth $= \pm 2^{\circ}$ \\
\hline & Distance $- \pm 0.5 \mathrm{~m}$ \\
\hline Section Lengths & $\pm 5 \mathrm{~cm}$ after "cookie" is cut \\
\hline Perpendicular Cuts & $\pm 10^{\circ}$ from perpendicular \\
\hline DHB and Stump Age & Conifers - \pm 1 year \\
\hline & Deciduous - \pm 5 years \\
\hline Increment Width & $\pm 5 \%$ for each set of years \\
\hline
\end{tabular}

\section{g. Plot Measurement Summary}

\begin{tabular}{|l|c|c|c|c|c|}
\hline Plot & $\begin{array}{c}\text { Length of } \\
\text { Side } \\
(\mathbf{m})\end{array}$ & $\begin{array}{c}\text { Area } \\
(\mathbf{h a})\end{array}$ & $\begin{array}{c}\text { Area } \\
\left(\mathbf{m}^{2}\right)\end{array}$ & $\begin{array}{c}\text { Buffer Side } \\
(\mathbf{m})\end{array}$ & $\begin{array}{c}\text { Buffer Area } \\
\left(\mathbf{( m}^{2}\right)\end{array}$ \\
\hline Tree & 31.62 & 0.100 & 1,000 & 200 & 40,000 \\
\hline & 38.73 & 0.150 & 1,500 & 237 & 56,250 \\
\hline & 44.72 & 0.200 & 2,000 & 300 & 90,000 \\
\hline & & & & & \\
\hline Sapling/Regen & 7.90 & 0.006 & 62 & & \\
\hline & 9.69 & 0.009 & 94 & & \\
\hline & 11.18 & 0.012 & 125 & & \\
\hline
\end{tabular}




\begin{tabular}{|l|l|c|c|}
\hline \multicolumn{1}{|c|}{ Plot } & \multicolumn{1}{|c|}{ Stem Size } & Tagged & $\begin{array}{c}\text { Number } \\
\text { Recorded }\end{array}$ \\
\hline Tree & $\geq 9.1 \mathrm{~cm} \mathrm{DBH}$ & Yes & 0001 \\
\hline & & & to 7999 \\
\hline Sapling & $1.3 \mathrm{~m}$ in height & Yes & 8001 \\
\hline & & & \\
\hline Regen & $\geq 0.10$ height up to a height of $<=1.29 \mathrm{~m}$ & No & 9998 \\
\hline & & & \\
\hline Outside of Plot & Representatives of stand age & No & 0000 \\
\hline
\end{tabular}

\section{h. Rounding-Off}

The following rules are to be followed for rounding off height measurements on sample trees.

1) Delay rounding off numbers as long as possible, preferably to the last stage, as rounding can significantly affect the accuracy of the final answer.

2) If the digit to be rounded is followed by a digit greater than 5 , round up.

$$
\begin{array}{ll}
\text { e.g. } \quad & 10.66 \ldots \ldots \ldots \ldots .10 .7 \\
& 16.394 \ldots \ldots \ldots \ldots . .16 .4(6,9 \& 7 \text { are greater than } 5) \\
& 21.17 \ldots \ldots \ldots \ldots . . .21 .2
\end{array}
$$

3) If the digit to be rounded is followed by a digit less than 5 , leave as is.

$$
\begin{array}{ll}
\text { e.g. } \quad & 10.64 \ldots \ldots \ldots . .10 .6 \\
& 10.339 \ldots \ldots \ldots . . .16 .3(4,3 \& 1 \text { are less than } 5) \\
& 21.11 \ldots \ldots \ldots \ldots . . .21 .1
\end{array}
$$

4) If the digit to be rounded is followed by a 5 then:

a) If the digits following the 5 are greater than 0 , round up.

$$
\begin{aligned}
& \text { e.g. } \quad 10.651 \ldots \ldots \ldots . . .10 .7 \\
& 16.359 \text {........... } 16.4 \\
& 21.154 \ldots \ldots \ldots . . .21 .2
\end{aligned}
$$

b) If the digit being rounded is followed by a 5 and no other digits then:

i) If the digit being rounded is odd, round up.

$\begin{array}{ll}10.55 \ldots \ldots \ldots \ldots . & 10.6 \\ 16.35 \ldots \ldots \ldots \ldots . & 16.4 \\ 21.15 \ldots \ldots \ldots \ldots . . & 21.2\end{array}$

ii) If the digit being rounded is even, leave as is.
10.65 10.6
16.45 16.4
21.25
25.5 25.0 
NOTE: The number 0 is considered to be an even number.

\section{MISTLETOE AND IMMATURE PLOT TYPES}

In September 1989 two new plot types were introduced:

i) $600-$ mistletoe plot type

ii) 700 - immature plot type ( 16 - 55 years old)

iii) The mistletoe plot type is established and re-measured according to the procedures outlines in Section 2.0. The severity of the mistletoe on the infected stem(s) is recorded using the 6 digit Hawksworth Mistletoe Rating System (see Figure 4.12 for rating system). Trees are sectioned in accordance with the A.F.S. Tree Sectioning Procedures Manual (see also Section 2.1.4.7).

Starting in 2000 field season in the immature plot, we do not have a minimum DBH requirement. All trees $\geq 1.3 \mathrm{~m}$ in height will be tagged and measured in the $1 / 16$ sapling/regen plot.

iv) In the remainder of the plot, all trees $\geq 9.1 \mathrm{~cm}$ at DBH are numbered and measured. Diameters, crown class and condition codes are assigned to each tree stem. Heights are measured according to procedures outlined in Section 2.1.4.4. All tagged trees are stem mapped.

NOTE: On the stems that are too small to withstand a nail, DBH is marked with a blue painted band so that future measurements are taken at the same point. A numbered tree tag is then placed loosely around the stem or a branch so as to prevent girdling of the stem. Seedling calipers or a baltimore stick is used to take sapling diameters.

When sectioning the immature plots three representative trees within the buffer are cut. When bucking, use $1.0 \mathrm{~m}$ section lengths.

In very dense stands, trees on the boundary of the tree plot, but not in the plot can have a yellow or orange vertical strip painted on them, facing into the tree plot. This will assist future re-measurements crews in determining border line trees. 


\section{STANDARD SAMPLE PLOT FILE FORMATS \\ KEYPUNCH AND MASTER FILES \\ (Format as of February, 2000)}

There are 4 record types found in these standard sample plot files:
a) Plot Header records (Type 01)
b) Tree description Records (Type 02)
c) Regeneration Records (Type 03)
d) GPS Records (Type 04)
e) Detail of Plot Treatment (Type 05)

\section{All numeric variables are right justified and character variables are left justified.}

Variable's abbreviated name is located before the variable description.

Record types are identified by a 2 digit code found in columns 38-39. A list of variables found in each record type is described below:

There are 15 different plot types and are as follows: Please advise FMD if plot type is not on list and put plot type in next available 2 digit position. Zero filled:

\section{Ptype: plot type}
1.) PSP Regular
2.) PSP Stand Dynamics Survey
3.) PSP Reforestation Monitor Plot
4.) TSP Operational Cruise
5.) TSP Inventory
6.) TSP Large Scale Photography
7.) Mistletoe
8.) Thinned
9.) Fertilized
10.) Herbicide
11.) Pruned
12.) Spruce Budworn
13.) Cleaned
14.) Thinned and Fertilized
15.) Herbicide and Thinned 
There are 3 different plot configuration types and are as follows: Please advise FMD if plot configuration is not on list and put plot configuration in next available position.

\section{Pconfig: plot configuration}

Fixed area (Any shape) $\quad-1$

Fixed area subplot $\quad-2$

Variable radius (Prism) plot $\quad-3$

There are 34 different Agency codes but this can be expanded. Please advise FMD if agency is not on list and put agency in next available 2-digit position. Zero filled. List is as follows:

\section{Agency}

\begin{tabular}{|c|c|}
\hline 01 - Alberta Forest Service & 02 - B.C. Forest Service \\
\hline 03 - Saskatchewan Forest Service & 04 - Pedology Consulting \\
\hline 05 - B.C. Forest Products. & 06 - Proctor and Gambler \\
\hline 07 - Champion Forest Products & 08 - Canfor (N.C.F.I) \\
\hline 09 - Ziedler Plywood Ltd. & $10-$ Makin Consulting \\
\hline 11 - Montreal Engineering & 12-Blue Ridge Lumber Co. \\
\hline 13-Pelican - Spruce Sawmil & 14- Special Projects \\
\hline 15 - University of Alberta & 16 - Canadian Forest Service \\
\hline 17 - Alberta Newsprint & 18-Alpac \\
\hline 19-Canadian Forest Products & 20 - Daishowa-Marubeni International \\
\hline 21 - Manning Diversified Forest Products & 22 - Millar Western \\
\hline 23 - Slave Lake Pulp Corp & 24 - Spray Lake Sawmill \\
\hline 25 - Sundance & 26 - Sunpine \\
\hline 27 - Tolko - High Prairie & 28 - Tolko - High Level \\
\hline 29 - Vanderwell & $30-$ Weldwood \\
\hline 31 - Weyerhaeuser - Drayton Valley & 32 - Weyerhaeuser - Edson \\
\hline 33 - Weyerhaeuser - Grande Prairie & 34 - Weyerhaeuser - Saskatchewan \\
\hline 35 - Weyerhaeuser - Slave Lake & \\
\hline
\end{tabular}

There are 3 different measurement types (number) and are as follows:

\section{Measure: measurement number}

TSP Always $=0$

PSP Establishment $=0$

PSP Re-measurement $=1,2,3$, etc.

In Record Type "01", subplot variable indicates if there is subplots within the plot. If "No" subplots (1 in record Type 1) then Subplot variable in other records left blank. Otherwise enter appropriate subplot number. 
a. RECORD TYPE "01" - STANDARD SAMPLE PLOT HEADER RECORDS

\begin{tabular}{|c|c|c|}
\hline Column & Description & ASCII Format \\
\hline $1-2$ & Ag: Agency & 12 \\
\hline $3-12$ & Plot: Plot number & 110 \\
\hline 13 & $\begin{array}{l}\text { Subplot: Subplot number } \\
\text { ( } 1=\text { No subplots and } 2=\text { Subplots })\end{array}$ & 11 \\
\hline $14-15$ & Measure: Measurement number & 12 \\
\hline $16-19$ & Year: Year of measurement & 14 \\
\hline $20-21$ & Month: Month of measurement & 12 \\
\hline $22-23$ & Day: Day of measurement & 12 \\
\hline $24-25$ & LSD: Legal subdivision & 12 \\
\hline $26-27$ & Sec: Section & 12 \\
\hline $28-30$ & Twp: Township & 13 \\
\hline $31-21$ & Rge: Range & 12 \\
\hline 33 & Mer: Meridian & 11 \\
\hline $34-36$ & Ptreat: Plot treatment & 13 \\
\hline 37 & Imp: Imperial & A1 \\
\hline $38-39$ & Recty: Record Type (Always '01') & 12 \\
\hline $40-46$ & Plotsize: Plot size $\left(\mathrm{m}^{2}\right)$ & F7.1 \\
\hline $47-53$ & Sapsize: Sapling Plot size $\left(\mathrm{m}^{2}\right)$ & F7.1 \\
\hline $54-60$ & Regsize: Regen Plot size $\left(\mathrm{m}^{2}\right)$ & F7.1 \\
\hline $61-71$ & Phase 1,2 or 3 Overstorey & A11 \\
\hline 61 & Dense: Overstorey Density class & A1 \\
\hline 62 & Htphase: Overstorey Height class & 11 \\
\hline $63-64$ & Spph1: Overstorey Species 1 & $\mathrm{~A} 2$ \\
\hline $65-66$ & Spph1: Overstorey Species 2 & $\mathrm{~A} 2$ \\
\hline $37-38$ & Spph1: Overstorey Species 3 & $\mathrm{~A} 2$ \\
\hline $69-70$ & Brack: Overstorey Bracketed Species & $\mathrm{A} 2$ \\
\hline 71 & Com: Overstorey Stand Commercialism & $\mathrm{A} 1$ \\
\hline $72-93$ & AVI Interpreted Overstorey & A22 \\
\hline 72 & Moistch: Moisture Regime (Alpha-small letter) & A1 \\
\hline 73 & Moistnu: Moisture Regime (Numeric) & 11 \\
\hline 74 & Crcch: Crown Closure Class (Alpha-cap letter) & A1 \\
\hline 75 & Crcnu: Crown Closure Class (Numeric) & 11 \\
\hline $76-77$ & Htc: Height to closest metre & 12 \\
\hline
\end{tabular}




\begin{tabular}{|c|c|c|}
\hline $78-79$ & Sp1: Species 1 (Capital + small) & $\mathrm{A} 2$ \\
\hline $80-81$ & Per1: Species 1 Percent ( $10 \%$ classes) & 12 \\
\hline $82-83$ & Sp2: Species 2 (Capital + small) & $\mathrm{A} 2$ \\
\hline 84 & Per2: Species 2 Percent ( $10 \%$ classes) & 11 \\
\hline $85-86$ & Sp3: Species 3 (Capital + small) & $\mathrm{A} 2$ \\
\hline 87 & Per3: Species 3 Percent ( $10 \%$ classes) & 11 \\
\hline $88-89$ & Sp4: Species 4 (Capital + small) & $\mathrm{A} 2$ \\
\hline 90 & Per4: Species 4 Percent ( $10 \%$ classes) & 11 \\
\hline $91-92$ & Sp5: Species 5 (Capital + small) & A2 \\
\hline 93 & Per5: Species 5 Percent ( $10 \%$ classes) & 11 \\
\hline $94-108$ & Phase 1,2 or 3 Understorey & A15 \\
\hline 94 & Denseu: Understorey Density class & A1 \\
\hline 95 & Htphaseu: Understorey Height class & 11 \\
\hline $96-97$ & Spph1u: Understorey Species 1 & $\mathrm{~A} 2$ \\
\hline $98-99$ & Spph2u: Understorey Species 2 & $\mathrm{~A} 2$ \\
\hline $100-101$ & Spph3u: Understorey Species 3 & $\mathrm{~A} 2$ \\
\hline $102-103$ & Bracku: Understorey Bracketed & $\mathrm{A} 2$ \\
\hline 104 & Commu: Understorey Stand Commercialism & A1 \\
\hline $105-108$ & Soringinu: Understorey Stand Origin & 14 \\
\hline $109-128$ & AVI Interpreted Understorey & A20 \\
\hline 109 & Crcchu: Crown Closure Class (Alpha-cap letter) & A1 \\
\hline 110 & Crcchu: Crown Closure Class (Numeric) & 11 \\
\hline $111-112$ & Hrcu: Height to closest metre & 12 \\
\hline $113-114$ & Spu1: Species 1 (Capital + small) & A2 \\
\hline $115-116$ & Peru1: Species 1 Percent (Capital + small) & 12 \\
\hline $117-118$ & Spu2: Species 2 (Capital + small) & $\mathrm{A} 2$ \\
\hline 119 & Peru2: Species 2 Percent (Capital + small) & 11 \\
\hline $120-121$ & Spu3: Species 3 (Capital + small) & $\mathrm{A} 2$ \\
\hline 122 & Peru3: Species 3 Percent (Capital + small) & 11 \\
\hline $123-124$ & Spu4: Species 4 (Capital + small) & $\mathrm{A} 2$ \\
\hline 125 & Peru4: Species 4 Percent (Capital + small) & I1 \\
\hline $126-127$ & Spu5: Species 5 (Capital + small) & $\mathrm{A} 2$ \\
\hline 128 & Peru5: Species 5 Percent (Capital + small) & 11 \\
\hline 129 & Locate: Location & 11 \\
\hline $130-132$ & Slope: Slope percent & 13 \\
\hline
\end{tabular}




\begin{tabular}{|c|c|c|}
\hline $133-134$ & Aspect: N, W, NE, NW, etc. NA= No Aspect & $\mathrm{A} 2$ \\
\hline $135-138$ & Elev: Elevation (m) & 14 \\
\hline 139 & Eros: Erosion potential & 11 \\
\hline 140 & Drain: Drainage & 11 \\
\hline $141-142$ & DMS: Depth to mineral soil $(\mathrm{cm})$ & 12 \\
\hline 143 & SVT: Surface vegetation type & I1 \\
\hline $144-146$ & Gnd: Ground cover percent & 13 \\
\hline 147 & Access & I1 \\
\hline 148 & Pldam: Plot damage & 11 \\
\hline 149 & Budam: Buffer damage & 11 \\
\hline $150-153$ & Estyr: Establishment Year & 14 \\
\hline $162-163$ & Ptype: Plot Type & 12 \\
\hline 164 & Pconfig: Plot Configuration & $\mathrm{I1}$ \\
\hline $180-183$ & Storigin: Stand origin & 14 \\
\hline 184 & SIA: Site Index/TPR & $\mathrm{A} 1$ \\
\hline $185-186$ & SII: Site Index/TPR & 12 \\
\hline $187-190$ & Photo: Photo year & 14 \\
\hline $191-193$ & Struct: Stand Structure & A3 \\
\hline $194-198$ & Ecosite & A5 \\
\hline $199-201$ & AspDeg: Aspect in Degrees & 13 \\
\hline 202 & Nutri: Nutrient Regime & $\mathrm{A} 1$ \\
\hline $203-204$ & Nregion: Natural region & 12 \\
\hline $205-208$ & Mindbh: Minimum Diameter measured (mm) & 14 \\
\hline $209-210$ & Stumpht: Stump Height (cm) & 12 \\
\hline 211 & Surf: Surface Expression & $\mathrm{A} 1$ \\
\hline 212 & Slopepos: Slope Position & $\mathrm{A} 1$ \\
\hline
\end{tabular}

\section{b. RECORD TYPE "02" - STANDARD TREE DESCRIPTION RECORD}

\begin{tabular}{|l|l|l|c|}
\hline \multicolumn{1}{|c|}{ Column } & \multicolumn{1}{|c|}{ Description } & ASCII Format \\
\hline $1-2$ & & Ag: Agency & 12 \\
\hline $3-12$ & & Plot: Plot number & 110 \\
\hline 13 & & LPSPSub: LFS PSP Subplot number & 11 \\
\hline $14-15$ & & Measure: Measurement number & 12 \\
\hline $16-19$ & & Year: Year of measurement & 14 \\
\hline
\end{tabular}




\begin{tabular}{|c|c|c|}
\hline $20-21$ & Month: Month of measurement & 12 \\
\hline $22-23$ & Day: Day of measurement & 12 \\
\hline $24-25$ & LSD: Legal subdivision & 12 \\
\hline $26-27$ & Sec: Section & 12 \\
\hline $28-30$ & Twp: Township & 123 \\
\hline $31-32$ & Rge: Range & 12 \\
\hline 33 & Mer: Meridian & 11 \\
\hline $34-36$ & Ptreat: Plot treatment & 13 \\
\hline 37 & Imp: Imperial & $\mathrm{A} 1$ \\
\hline $38-39$ & Recty: Record Type (Always '02') & 1 \\
\hline $40-43$ & Tree: Tree number & $\mathrm{I}$ \\
\hline $44-45$ & Sp: Species (Caps) & A2 \\
\hline \multicolumn{3}{|c|}{ On No Tally Plots Enter Tree $=0001$ and $S p=$ NO) } \\
\hline $46-49$ & Dbh: Diameter Breast Height (mm) & 14 \\
\hline $50-53$ & Ht: Height (dm) & 14 \\
\hline $54-57$ & Htlcrn: Height to live crown (dm) & 14 \\
\hline 58 & Cclass: Crown Class & A1 \\
\hline $59-60$ & Cond1: Condition Code 1 & 12 \\
\hline $61-62$ & Cond2:Condition Code 2 & 12 \\
\hline $63-64$ & Cond3:Condition Code 3 & 12 \\
\hline $65-67$ & Dbhage: Diameter Breast Age & 13 \\
\hline $68-70$ & Stumpage: Stump Age & 13 \\
\hline $71-73$ & Inc10: Increment Prev. 10 yrs (mm) & 14 \\
\hline $74-76$ & Inc20: Increment Prev. $11-20$ yrs (mm) & 14 \\
\hline $77-79$ & Azimuth & 13 \\
\hline $80-82$ & Distance $(\mathrm{dm})$ & 13 \\
\hline 83-89 & Plotsize: Plot/subplot size $\left(\mathrm{m}^{2}\right)$ & F7.1 \\
\hline $90-96$ & Sapsize: Sapling Plot size $\left(\mathrm{m}^{2}\right)$ & F7.1 \\
\hline $97-103$ & Regsize: Regen Plot size $\left(\mathrm{m}^{2}\right)$ & F7.1 \\
\hline $104-107$ & Estyr: Establishment year & 14 \\
\hline 108 & Crstat: Crown status & $\mathrm{A} 1$ \\
\hline 109-112 & Crn: Crown Width North (dm) & 14 \\
\hline
\end{tabular}




\begin{tabular}{|l|l|l|c|}
\hline $113-116$ & & Crw: Crown Width West (dm) & 14 \\
\hline $117-120$ & & Crs: Crown Width South (dm) & 14 \\
\hline $121-124$ & & Cre: Crown Width East (dm) & 14 \\
\hline $125-126$ & & Subplot: Subplot number & 12 \\
\hline $127-141$ & & Stand: Stand/Polygon number & 115 \\
\hline $142-146$ & & Stump: Stump Diameter (mm) & 15 \\
\hline
\end{tabular}

\section{c. RECORD TYPE "O3" - STANDARD REGENERATION RECORD}

\begin{tabular}{|c|c|c|}
\hline Column & Description & ASCII Format \\
\hline $1-2$ & Ag: Agency & 12 \\
\hline 3-12 & Plot: Plot number & 110 \\
\hline 13 & LPSPSub: LFS PSP Subplot number & $\mathrm{I1}$ \\
\hline $14-15$ & Measure: Measurement number & 12 \\
\hline 16-19 & Year: Year of measurement & 14 \\
\hline $20-21$ & Month: Month of measurement & 12 \\
\hline $22-23$ & Day: Day of measurement & 12 \\
\hline $24-25$ & LSD: Legal subdivision & 12 \\
\hline $26-27$ & Sec: Section & 12 \\
\hline $28-30$ & Twp: Township & 13 \\
\hline $31-32$ & Rge: Range & 14 \\
\hline 33 & Mer: Meridian & 11 \\
\hline $34-36$ & Ptreat: Plot treatment & 13 \\
\hline 37 & Imp: Imperial & $\mathrm{A} 1$ \\
\hline $38-39$ & Recty: Record Type (Always '03') & 12 \\
\hline $40-43$ & Tree: Tree number & 14 \\
\hline $44-45$ & Sp: Species (Caps) & A2 \\
\hline \multicolumn{3}{|c|}{ (On No Tally Plots Enter $\mathrm{Sp}=\mathrm{NO}$ ) } \\
\hline $46-48$ & Regen 1: Regeneration in height class 1 & 13 \\
\hline $49-51$ & Regen 2: Regeneration in height class 2 & 13 \\
\hline $52-54$ & Regen 3: Regeneration in height class 3 & 13 \\
\hline $55-57$ & Regen 4: Regeneration in height class 4 & 13 \\
\hline $58-60$ & Regen 5: Regeneration in height class 5 & 13 \\
\hline
\end{tabular}




\begin{tabular}{|l|l|l|c|}
\hline $61-67$ & Plotsize: Plot size $\left(\mathrm{m}^{2}\right)$ & $\mathrm{F} 7.1$ \\
\hline $68-74$ & & Sapsize: Sapling Plot size $\left(\mathrm{m}^{2}\right)$ & $\mathrm{F} 7.1$ \\
\hline $75-81$ & & Regsize: Regen Plot size $\left(\mathrm{m}^{2}\right)$ & $\mathrm{F} 7.1$ \\
\hline $82-85$ & & Estyr: Establishment Year & 14 \\
\hline $86-87$ & & Subplot: Subplot number & \\
\hline
\end{tabular}

d. RECORD TYPE '04' - STANDARD GPS RECORDS

\begin{tabular}{|c|c|c|}
\hline Column & Description & ASCII Format \\
\hline $1-2$ & Ag; Agency & 12 \\
\hline 3-12 & Plot: Plot number & 110 \\
\hline $13-14$ & Sec: Section & 12 \\
\hline $15-17$ & Twp: Township & 13 \\
\hline $18-19$ & Rge: Range & 12 \\
\hline 20 & Mer: Meridian & 11 \\
\hline $21-22$ & Subplot: Subplot number & 12 \\
\hline $23-37$ & Stand: Stand/Polygon number & $\mid 15$ \\
\hline $38-39$ & Reacty: Record Type (Always '04') & 12 \\
\hline $40-44$ & Declong: Longitude Dec. Degrees & $\mathrm{F} 15.10$ \\
\hline $45-59$ & Declat: Latitude Dec. Degrees & F15.10 \\
\hline $60-70$ & Easting & F11.5 \\
\hline $71-81$ & Northing & F11.5 \\
\hline $82-85$ & UTM & 14 \\
\hline $86-87$ & NAD (Preferable 83) & 12 \\
\hline
\end{tabular}

e. DETAIL OF PLOT TREATMENT (TYPE 05) - On progress 


\section{TREE SPECIES CODE}

Only the following species will be measured:

\section{Common Name \\ Genus/Species}

Fir

Alpine fir

Balsam fir

Birch

White birch

Douglas-fir

Douglas-fir

Larch

Alpine larch

Tamarack

Western larch

Pine

Limber pine

Jack pine

Lodgepole pine

Whitebark pine

\section{Poplar}

Aspen (White Poplar)

Balsam poplar (Black poplar)

\section{Spruce}

Black spruce

Englemann spruce

White spruce
Scientific Name Code

Species

\section{Abies}

A. lasiocarpa

FA

A. balsamea

$F B$

Betula

B. papyrifera

BW

Pseudotsuga

P. menziesii

FD

Larix

L. Iyalii

L. laricina

LA

L. occidentalis

LT

LW

$\underline{P \text { inus }}$

P. flexilis PF

P. banksiana PJ

P. contorta PL

P. albicaulis PW

\section{Poplus}

P. tremuloides

AW

P. balsamifera

PB

Picea

P. mariana SB

P. englemannii SE

P. glauca SW 


\section{PLANT SPECIES CODE}

\section{TREE LAYER}

Species Code

ABIE BAL

ABIE LAS

BETU PAP

DC

DD

LARI OCC

LARI LAR

LARI LYA

PICE MAR

PICE GLA

PICE ENG

PINU CON

PINU FLE

PINU ALB

POPU BAL

POPU TRE

PSEU MEN
Latin Name

Abies balsamifera

Abies lasiocarpa

Betula papyrifera

Larix occidentalis

Larix laricina

Larix lyallii

Picea mariana

Picea glauca

Picea engelmannii

Pinus contorta

Pinus flexilis

Pinus albicaulis

Populus balsamifera

Populus tremuloides

Pseudotsuga menziesii
Common Name

Balsam Fir

Alpine Fir

White Birch

Dead conifer

Dead Deciduous

Western Larch

Larch

Alpine Larch

Black Spruce

White Spruce

Engleman Spruce

Lodgepole Pine

Limber Pine

Whitebark Pine

Balsam Poplar

Aspen

Douglas Fir

SHRUB LAYER

Species Code

ARCT UVA

ALNU CRI

ALNU TEN

AMEL ALN

BERB REP

BETU GLA

BETU PUM

BETU OCC

CHIM UMP

CLEM OCC

CORN STO

CORY COR

GAUL HIS

JUNI COM

JUNI HOR

LEDU GRO

LINN BOR

LONI DIO

\section{Latin Name}

Arctostaphylos uvaursi

Alnus crispa

Alnus tenuifolia

Amelanchier alnifolia

Berberis repens

Betula glandulosa

Betula pumila v.

glandulifera

Betula occidentalis

Chimaphila umbellata

Clematis occidentalis

Cornus stolonifera

Corylus cornuta

Gaultheria hispidula

Juniperus communis

Juniperus horizontalis

Ledum groenlandicum

Linnaea borealis

Lonicera dioica $v$.

glaucescens
Common Name

Bearberry, Kinnickkinnick

Green Alder

River Alder

Saskatoon Berry

Creeping Mahonia

Dwarf Birch

Swamp Birch

Water Birch

Prince's Pine

Purple clematis

Red Osier Dogwood

Beaked Hazelnut

Creeping Snowberry

Ground Juniper

Creeping Juniper

Labrador Tea

Twinflower

Twining honeysuckle 


$\begin{array}{ll}\text { LONI INV } & \text { Lonicera involucrata } \\ \text { LONI UTA } & \text { Lonicera utahensis } \\ \text { MENZ FER } & \text { Menziesia ferruginea } \\ \text { HOR } & \text { Oplopanax horridum } \\ \text { OXYC MIC } & \text { Oxycoccus microcarpus } \\ \text { POTE FRU } & \text { Potentilla fruticosa } \\ \text { POTE NOR } & \text { Potentilla norvegica } \\ \text { PRUN PEN } & \text { Prunus pensylvanica } \\ \text { PRUN VIR } & \text { Prunus virginiana } \\ \text { PRUN SP } & \text { Prunus species } \\ \text { RHOD ALB } & \text { Rhododendron albiflorum } \\ \text { RIBE GLA } & \text { Ribes glandulosum } \\ \text { RIBE HIR } & \text { Ribes hirtellum } \\ \text { RIBE HUD } & \text { Ribes hudsoniaum } \\ \text { RIBE LAC } & \text { Ribes lacustre } \\ \text { RIBE OXY } & \text { Ribes oxyacanthoides } \\ \text { RIBE TRI } & \text { Ribes triste } \\ \text { RIBES SP } & \text { Ribes species } \\ \text { ROSA ACI } & \text { Rosa acicularis } \\ \text { ROSA SP } & \text { Rosa species } \\ \text { ROSA WOO } & \text { Rosa woodsii } \\ \text { RUBU IDA } & \text { Rubus idaeus } \\ \text { RUBU PAR } & \text { Rubus parviflorus } \\ \text { RUBU SP } & \text { Rubus species } \\ \text { SALI ATH } & \text { Salix athabascensis } \\ \text { SALI BAR } & \text { Salix barklayi } \\ \text { SALI BEB } & \text { Salix bebbiana } \\ \text { SALI GLA } & \text { Salix glauca } \\ \text { SALI MYR } & \text { Salix myrtillifolia } \\ \text { SALI PED } & \text { Salix pedicellaris } \\ \text { SALI PET } & \text { Salix petiolaris } \\ \text { SALI PYR } & \text { Salix pyrifolia } \\ \text { SALI SCO } & \text { Salix scouleriana } \\ \text { SALI SP } & \text { Salix species } \\ \text { SAMB RAC } & \text { Sambucus Racemosa } \\ \text { SHEP CAN } & \text { Shepherdia canadensis } \\ \text { SORB SCO } & \text { Sorbus scopulina } \\ & \end{array}$

Bracted Honeysuckle

Red Twinberry

MenziesiaPLO

Devil's Club

Small Bog Cranberry

Shrubby Cinquefoil

Rough Cinquefoil

Pin Cherry

Choke Cherry

Cherry

White-flowered Rhododendron

Skunk Currant

Wild Gooseberry

Northern Black Currant

Bristly Black Currant

Wild Gooseberry

Wild Red Currant

Prickly Rose

Rose

Common Wild Rose

Wild Red Raspberry

Thimble Berry

Raspberry Species

Willow

Barclay's Willow

Beaked Willow

Smooth Willow

Myrtle-leaved willow

Bog Willow

Basket Willow

Balsam Willow

Willow

Willow

Red Elderberry

Canadian Buffaloberry

Mountain Ash 
SPIR BET

SPIR DEN

SPIR SP

SYMP ALB

SYMP OCC

VACC CAE

VACC MEM

VACC MYR

VACC MYT

VACC SCO

VACC ULI

VACC VIT

VIBU EDU

VIBU OPU
Spiraea betulifolia

Spiraea densiflora

Spiraea species

Symphoricarpos albus

Symphoricarpos occidentalis

Vaccinium caespitosum

Vaccinium membranaceum

Vaccinium myrtilloides

Vaccinium myrtillus

Vaccinium scoparium

Vaccinium ulignosum

Vaccinium vitis-idaea v. minus

Viburnum edule

Viburnum opulus
Birch-leaved Spirea

Pink Meadowsweet

Meadowsweet

Snowberry

Wolfberry

Dwarf Bilberry

Tall Bilberry

Blueberry

Low Bilberry

Grouse-berry

Bog Bilberry

Bog Cranberry

Lowbush Cranberry

High-bush Cranberry

\section{GRASS LAYER}

Species Code

Latin Name

Common Name

(POA species - Record 1st 3 letters of genus and 1 st 4 letters of species)

$\begin{array}{lll}\text { AGRO RIP } & \text { Agropyron riparium } & \text { Steambank } \\ \text { AGRO SMI } & \text { Agropyron smitthi } & \begin{array}{l}\text { Weatgrass } \\ \text { Western Wheatgrass } \\ \text { Bearded }\end{array} \\ \text { AGRO SUB } & \begin{array}{l}\text { Agropyron subsecundum } \\ \text { Wheatgrass }\end{array} & \text { Slender } \\ \text { AGRO TRA } & \text { Agropyron trachycaulum } & \text { Wheatgrass } \\ & \text { Wlopecurus aequalis } & \text { Water Foxtail } \\ \text { ALOP AEQ } & \text { Agrostis Scabra } & \text { Hair Bentgrass } \\ \text { AGRO SCA } & \text { Agropyron species } & \\ \text { AGRO SP } & \text { Avena fatua } & \text { Wild Oat } \\ \text { AVEN FAT } & \text { Bromus carinatus } & \text { Brome } \\ \text { BROM CAR } & \text { Bromus inermis } & \text { Awnless Brome } \\ \text { BROM INE } & \text { Bromus ciliatus } & \text { Fringed Brome } \\ \text { BROM CIL } & \text { Bromus vulgaris } & \text { Columbia Brome } \\ \text { BROM VUL } & \text { Calamagrostis canadensis } & \text { Bluejoint } \\ \text { CALA CAN } & & \text { Marsh Reed } \\ & \text { Calamagrostis inexpansa } & \text { Northern Reed } \\ \text { CALA INE } & & \text { Grass } \\ \text { CALA NEG } & \text { Calamagrostis neglecta } & \text { Narrow, Plains } \\ \text { CALA PUR } & \text { Calamagrostis purpurascens } & \text { Reed Grass } \\ & & \text { Purple Reed } \\ \text { CALA RUM } & \text { Calamgrostis rubescens } & \text { Grass } \\ \text { CARE AQU } & \text { Carex aquatilis } & \text { Pinegrass } \\ \text { CARE BEB } & \text { Carex bebbi } & \text { Water Sedge } \\ & & \text { Sedge }\end{array}$


Species Code

CARE BRU

CARE CON

CARE DIS

CARE FOE

CARE GYN

CARE HOU

CARE LAS

CARE LEP

CARE OBT

CARE PRA

CARE RIC

CARE ROS

CARE SP

CARE UMB

CARE VAG

CINN LAT

DANT PAR

DESC CAE

DIST STR

ELYM INN

ELYM SP

ERIO POL

ERIO SP

FEST OCC

FEST PRA

FEST RUB

FEST SAX

FEST SCA

FEST SP

GYLYC STR

GRASS SP

HIER ALP.

HIER ODO

HORD JUB

JUNC BAL

KOEL CRI

LUZU PAR

ORYZ ASP

ORYZ PUN

PANI SP

PHLE PRA
Latin Name

Carex brunnescens

Carex concinna

Carex disperma

Carex foenea

Carex gynocrates

Carex houghtoniana

Carex lasiocarpa

Carex leptales

Carex obtusata

Carex praticola

Carex richardsonii

Carex rostrata

Carex species

Carex umbellata

Carex vaginata

Cinna latifolia

Danthonid parryi

Deschampsia caespitosa

Distichlis stricta

Elymus innovatus

Elymus species

Eriophorum polystachion

Eriophorum species

Festuco occidentalis

Festuca pratensis

Festuca rubra

Festuca saximontana

Festuca scabrella

Festuca species

Glyceria striata

Hierochloe Alpina

Hierochloe odorata

Hordeum jubatum

Juncus balticus

Koeleria cristata

Luzula parviflora

Oryzopsis asperifolia

Oryzopsis pungens

Panicum species

Phleum pratense
Common Name

Brownish Sedge

Beautiful Sedge

Two-seeded Sedge

Sedge

Northern Bog Sedge

Carex

Hairy-fruited Sedge

Bristle Stalked Sedge

Blunt Sedge

Sedge

Richardson's Sedge

Beaked Sedge

Carex Species

Umbellate Sedge

Sheathed Sedge

Drooping Wood Reed

Parry's Oatgrass

Tufted Hair Grass

Salt Grass

Hairy Wild Rye

Wild Rye

Cotton Grass

Cotton Grass

Western Fescue

Meadow Fescue

Red Fescue

Sheet Fescue

Rough Fescue

Fescue Species

Fowl Manna Grass

Grass species

Alpine Sweetgrass

Common Sweetgrass

Foxtale Barley

Wire Rush

June Grass

Small-flowered Woodrush

Mountain Rice Grass

Short-awned Rice Grass

Panic Grass

Timothy Grass 
Species Code

PHRA AUS

POA GLAU

POA INTE

POA PALU

POA PRAT

POA SP

SCHI PUR

TRIS SPI

XERO TEN
Latin Name

Phragmites australis

Poa glauca

Poa interior

Poa palustris

Poa pratensis

Poa species

Schizachne purpurascens

Trisetum spicatum

Xerophyllum tenax
Common Name

Reed

Bluegrass

Bluegrass

Fowl Bluegrass

Kentucky Bluegrass

False Melic

Spike Trisetum

Bear Grass

\section{HERB LAYER}

Species Code

ANAP MAR

ACHI MIL

$\mathrm{ACHI}$ SIB

ACHI SP

ACTA RUB

AGOS GLA

AGOS SP

ALLI CER

ANEM MUL

ANTE MIC

ANTE SP

ANTE NEG

ANTE PUL

ANTE RAC

ANTE ROS

APOC AND

AQUI BRE

AQUI FLA

ARAL NUD

ARCE AME

ARNI CHA

ARNI COR

ARNI LAT

ARNI LON

ARNI SP

ASTR SP

ARTE CAM

ARTE FRI

\section{Latin Name}

Anaphalis margaritacea

Achillea millefolium

Achillea sibirica

Achillea species

Actaea rubra

Agoseris glauca

Agoseris species

Allium cernum

Anemone multifida

Antennaria microphylla

Antennaria species

Antennaria neglecta

Antennaria pulcherrima

Antennaria racemosa

Antennaria rosea

Apocynum androsaemifolium

Aquilegia brevistyla

Aquilegia flavescens

Aralia nudicaulis

Arceuthobium americanum

Arnica chamissonis

Arnica cordifolia

Arnica latifolia

Arnica longifolia

Arnica species

Astragalus species

Artemisia campestris

Artemisia frigida $\mathrm{v}$.

americanus

\section{Common Name}

Pearly Everlasting

Common Yarrow

Yarrow

Yarrow Species

Red Baneberry

Pale False Dandelion

False Dandelion

Nodding Onion

Windflower,

Cutleaf Anemone

Rossy Pussytoes

Showy Everlasting

Racemose Everlasting

Rosy Everlasting

Spreading Dogbane

Blue Columbine

Yellow Columbine

Wild Sarasparilla

Dwarf Mistletoe

Leafy Arnica

Heart-leaved Arnica

Mountain Arnica

Long-leaved Arnica

Arnica

Milk Vetch

Plains Wormwood

Pasture Sage 
Species Code

ASTE CIL

ASTE CON

ASTE FOL

ASTE JUN

ASTE LAE

ASTE SP

ASTR ALP

ASTR EUC

ASTR FRI

ASTR STR

BOTR VIR

CALY BUL

CAMP ROT

CAST MIN

CAST PAR

CAST SP

CERA ARV

CERA SP

CHRY IOW

CHRY LEU

CICU MAC

CIRS ARV

CIRS HOO

CIRS SP

CIRS VUL

CORA MAC

CORA TRI

CORN CAN

CORY AUR

CORY SEM

CORY SP

CREP SP

CREP TEC

CYST FRA

DELP GLA

DISP TRA

DODE RAD

DRAB AUR

DRYO CRI

DRYO EXP

DRYO SP

DRYO SPI

ERIG GLA
Latin Name

Aster ciliolatus

Aster conspicuous

Aster folicaeus

Aster junciformis

Aster laevis

Aster species

Astragalus alpinus

Astragalus eucosmus

Astragalus frigidus

Astragalus striatus

Botrychium virginianum

Calypso bulbosa

Campanula rotundifolia

Castilleja miniata

Catilleja parviflora

Castilleja species

Cerastium arvense

Cerastium species

Chrysoplenium iowense

Chrysanthemum leucanthemum

Cicuta maculata

Cirsium arvense

Cirsium hookerianum

Cirsium species

Cirsium vulgare

Corallorhiza maculata

Corallorhiza trifida

Corn canadensis

Corydalis aurea

Corydalis sempervirens

Corydalis species

Crepis species

Crepis tectorum

Cystopteris fragilis

Delphinium glaucum

Disporum trachyearpum

Dodecatheon radicatum

Draba aurea

Dryopteris cristata

Dryopteris expansa

Dryopteris species

Dryopteris spinulosa

Erigeron glabellus
Common Name

Lindley's Aster

Showy Aster

Aster

Rush Aster

Smooth Aster

Aster species

Alpine Milk Vetch

Milk Vetch

American Milk Vetch

Ascending Purple Milk Vetch

Grape Fern

Venus' Slipper

Bluebell, Harebell

Red Indian Paintbrush

Small Flowered Paintbrush

Paintbrush

Field Chickweed

Chickweed species

Golden Saxifrage

Ox-eye Daisy

Water Hemlock

Canada Thistle

White Thistle

Thistle Species

Bull Thistle

Spotted Coralroot

Pale Coralroot

Bunch Berry

Yellow Corydalis

Pink/Pale Corydalis

Corydalis

Hawksbeard species

Annual Hawksbeard

Bladder Fern

Tall Larkspur

Fairy-bells

Shooting Star

Golden Whitlow-Grass

Fern

Spiny Woodfern

Fern

Narrow Spinulose Shield Fern

Wild Daisy 
Species Code

EPIL ANG

EQUI ARV

EQUI PRA

EQUI SCI

EQUI SP

EQUI SYL

EQUI VAR

ERIG PER

ERIG SP

FRAG VIR

GAIL ARI

GALE TET

GALI BOR

GALI TRI

GENT AMA

GENT SP

GEOC LIV

GERA RIC

GERA SP

GERA VIS

GEUM ALE

GEUM MAC

GEUM RIV

GEUM TRI

GOOD REP

GYMN DRY

HABE HYP

HABE OBT

HABE ORB

HABE VIR

HALE DEF

HEDY ALP

HEDY SP

HERA LAN

HIER ALB

HIER CAN
Latin Name

Epilobium angustifolium

Equisetum arvense

Equisetum pratense

Equisetum scirpoides

Equisetum species

Equisetum sylvaticum

Equisetum variegatum

Erigeron peregrinus $v$.

callianthemus

Erigeron species

Fragaria virginiana

Gaillardia aristata

Galeopsis tetrahit

Galium boreale

Galium triflorum

Gentianella amarella

Gentianella species

Geocaulon lividum

Geranium richardsonii

Geranium species

Geranium viscosissimum

Geum aleppicum

Geum macrophyllum

Geum rivale

Geum triflorum

Goodyera repens

Gymnocarpium dryopteris

Habenaria hyperborea

Habenaria obtusata

Habenaria orbiculata

Habenaria viridis v.

bracteata

Halenia deflexa

Hedysarum alpinum v.

americanum

Hedysarum species

Heracleum lanatum

Hieracium albiflorum

Hieracium canadense
Common Name

Fireweed

Field Horsetail

Meadow Horsetail

Dwarf Scouring Rush

Horsetail Species

Woodland Horsetail

Variegated Horsetail

Wondering Daisy

Fleabane

Wild Strawberry

Gaillardia

Hemp Nettle

Northern Bedstraw

Sweet-Scented Bedstraw

Felwort, Northern Gentian

Gentian species

Bastard Toadflax

Richardson Geranium

Geranium

Sticky purple geranium

Yellow Avens

Yellow Avens

Purple or Water Avens

Old Man's Whiskers

Rattlesnake Plantain

Oak Fern

Northern Green Orchid

Blunt-leaved Orchid

Round-leaved Orchid

Bracted Orchid

Spurred Gentian

American Hedysarum

Hedysarum

Cow Parsnip

White hawkweed

Canada Hawkweed 
HIER SP

HIER UMB

LATH OCH

LATH VEN

LILI PHI

LINU LEW

LIST BOR

LIST COR

LYCH DRU

LYCO ANN

LYCO COM

LYCO SP

LUPI ARG

MAIA CAN

MELI ALB

MELI OFF

MERT PAN

MITE NUD

ORCH ROT

ORTH SEC

OSMO CHI

OSMO DEP

OXYT CAM

OXYT SER

OXYT SPL

PARN FIM

PARN PAL

PEDI BRA

PEDI CAP

PEDI GRO

PEDI LAB

PENS PRO

PETA PAL

PETA SAG
Hieracium species

Hieracium umbellatum

Hawkweed

Lathyrus ochroleucus

Vetchlin

Lathyrus venosus

Lilium philadelphicum

Linum lewisii

Listera borealis

Listera cordata

Lychnis drummondii

Lycopodium annotinum

Lycopodium complanatum

Lycopodium species

Lupinus argenteus

Maianthemum canadense

Melilotus alba

Melilotus officinalis

Mertensia paniculata

Mitella nuda

Orchis rotundifolia

Orthilia secunda

Osmorhiza chilensis

Osmorhiza depauporata

Oxytropis campestris

Oxytropis sericeus v. spicata

Oxytropis splendens

Parnassia fimbriata

Parnassia palustris

Pedicularis bracteosa

Pedicularis capitata

Pedicularis groenlandicam

Pedicularis labradoricam

Penstemon procerus

Petasites palmatus

Petasites sagittatus
Hawkweed species

Narrow-leaved

Cream-coloured

Peavine

Western Wood

Lily

Wild Blue Flax

Western Twayblade

Heart-leaved Twayblade

Drummond's Cocle

Stiff Club-Moss

Ground Cedar

Club-moss

Perennia lupine

Wild Lily-of-the-Valley

White sweet clover

Yellow sweet clover

Tall Mertensia, Lungwort

Bishop's Cap, Mitrewort

Round-leaved Orchid

One-Sided Wintergreen

Blunt-fruited Sweet Cicely

Sweet Cicely

Late Yellow Locoweed

Early Yellow Locoweed

showy loco-weed

Fringed Grass-of Parnas

Northern grass-of parnassus

Bracted lousewort

Few-flowered lousewort

Elephant Head

Labrador Lousewort

Slender Blue Beardtongue

Palmate-leaved Coltsfoot

Arrow-leaved Coltsfoot 
PICR ECH

PLAN MAJ

POLY BIS

POLY CAE

POLY VIV

POTE ARG

POTE GLA

POTE GRA

PYRO ASA

PYRO BRA

PYRO CHL

PYRO ORB

PYRO SP

RANU ACR

RHIN CRI

RHIN MIN

RUBU ARC

RUBU PED

RUBU PUB

RUBU SP

RUME ACE

RUME OCC

SAXI BRO

SCIR VAL

SCUT GAL

SEDU STE

SELA DEN

SENE CAN

SENE PAU

SENE PSE

SENE SP

SENE TRI

SMIL RAC

SMIL STE

SMIL TRI

SOLI CAN

SOLI GIG

SOLI MUL
Picris echioides

Plantago major

Polygonum bistortoides

Polygonum caeruleum spp. occidentale

Polygonum viviparum

Potentilla arguta

Potentilla glandulosa spp.

pseudorupestris

Potentilla gracilis

Pyrola asarifolia

Pyrola bracteata

Pyrola chlorantha

Pyrola species

Ranunculus acris

Rhinanthus cristagalli

Rhinanthus minor

Rubus arcticus

Rubus pedatus

Rubus pubescens

Rubus species

Rumex acetosa

Rumex occidentalis v. fenestratus

Saxifraga bronchialis

Scirpus validus

Scutellaria galericulata

Sedum stenopetalum

Selaginella densa

Senecio canus

Senecio pauperculus

Senecio pseudaureus

Senecio species

Senecio triangularis

Smilacina racemosa

Smilacina stellata

Smilacina trifolia

Solidago canadensis

Solidago gigantea

Solidago multiradiata
Bristly ox-tongue common plantain

Western Bistort

Jacob's Ladder

Alpine Bistort

White Cinquefoil

Cinquefoil

Graceful Cinquefoil

Common Pink Wintergreen

Large wintergreen

Green Wintergreen

Wintergreen

Tall buttercup

Yellow Rattle

Yellow rattle

Dwarf Raspberry

Five-leaved bramble

Dewberry

Green sorrel

Western Dock

Prickly Saxifrage

Common great bulrush

Skullcap

Common Stonecap

Prairie Selaginella

Prairie Groundsel

Balsam Groundsel

Stream bank butterweed

Graundsel

Arrow-leaved groundsel

False Solomon's Seal

Star-flowered Solomon Seal

Three-leaved Solomon Seal

Canada goldenrod

Goldenrod

Alpine Goldenrod 
SOLI SP

SOLI SPA

SONC ARV

SONC SP

SPIR ROM

STEL CAL

STEL LON

STEL SP

STEN OCC

STRE AMP

TANA VUL

TARA CER

TARA OFF

TARA SP

THAL VEN

THER RHO

TRIF AUR

TRIF PRA

TRIF REP

TRIF SP

THPH LAT

URTI DIO

VERA ESC

VERO SP

VERO WOR

VICI AME

VIOL ADU

VIOL CAN

VIOL REN

VIOL RUG

VIOL SP

ZIZI APT

ZYGA ELE
Solidago species

Solidago spathulata

Sonchus arvensis

Sonchus species

Spiranthes romanzoffiana

Stellaria calycantha

Stellaria longifolia

Stellaria species

Stenanthium occidentale

Streptopus amplexifolius

Tanacetum vulgare

Taraxacum ceratophrum

Taraxacum officinale

Taraxacum species

Thalictrum venulosum

Thermopsis rhombifolia

Trifolium aureum

Trifolium pratense

Trifolium repens

Trifolium species

Typhia latifolia

Urtica dioica

Veratrum eschscholtzii

Veronica species

Veronica wormskioldii

Vicia americana

Viola adunca

Viola canadensis

Viola renifolia

Viola rugulosa

Viola species

Zizia aptera

Zygadenus elegans
Goldenrod species

Spike Like Golden Rod

Perennial sow thistle

Sow thistle

Ladies' Tresses

Northern starwort

Long-leaved Chickweed

Starwort species

Bronze Bells

Twisted Stalk

Common tansy

Horned Dandelion

Common Dandelion

Veiny Meadow Rue

Golden bean

Hop clover

Red Cover

White Clover

Clover Species

Cattail

Common nettler

False hellebore

Alpine Speedwell

Wild Vetch

Early Blue Violet

Canada Violet

Kidney-leaved Violet

Western Canada Violet

Violet

Meadow Parsnip

Death Camas 


\section{Species Code}

AMBL SER

ANAS HEL

AULA PAL

AULA SP

BARB HAT

BRAC OED

BRAC SAL

BRAC STA

BRAC TUR

BRYU CAE

BRYU PSE

CALL GIG

CALY SPH

CAMP CHR

CAMP HIS

CAMP STE

CEPH LUN

CERA PUR

CLAD BAC

CLIM DEN

DICR ACU

DICR CON

DICR ELO

DICR FLA

DICR FRA

DICR FUS

DICR GRO

DICR MUE

DICR POL

DICR SCO

DICR SP

DICR UND

DIST CAP

DREP ADU

DREP REV

DREP UNC

DREP VER

EURH PUL

FUNA HYG

GEOC GRA

HEDW CIL

\section{Latin Name}

\section{Common Name}

Amblystegium serpens

Anastrophyllum helleranum

Aulacomnium palustre

Aulacomnium species

Barbilophozia hatcheri

Brachythecium Oedipum

Brachythecium salebrosum

Brachythecium starkei

Brachythecium turgidum

Bryum caespiticium

Bryum pseudotriquetrum

Calliergon giganteum

Calypogeja sphagnicola

Campylium chrysophyllum

Campylium hispidulum

Campylium stellatum

Cephalozia lunufifolia

Ceratodon purpureus

Cladonia bacillaris

Climacium dendroides

Dicranum acutifolium

Dicranum condensatum

Dicranum elongatum

Dicranum flagellare

Dicranum fragilifolium

Dicranum fuscenscens

Dicranum groenlandicum

Dicranum muehlenbeckii v.cirratum

Dicranum polysetum

Dicranum scoparium

Dicranum species

Dicranum undulatum

Distichium capillaceum

Drepanocladus aduncus

Drepanocladus revolvens

Drepanocladus uncinatus

Drepanocladus vernicosus

Eurhynchium pulchellum

Funaria hygrometrica

Geocalyz graveolans

Hedwigia ciliate

Fire Moss
Glow Moss

Liverwort

Short-leaved Ragged Moss 
HYLO SP

HYLO SPL

HYPN PRA

HYPN REV

JAME AUT

LEPI REP

LEPT PYR

LOPH GUT

LOPH INC

LOPH LON

LOPH VEN

MNIU SP

MNIU SPI

MYLI ANO

MYUR JUL

ONCO WAH

ORTH RUP

ORTH SPE

PLAG ASP

PLAG CUS

PLAG DRU

PLAG MED

PLEU SCH

POHL NUT

POLY

POLY COM

POLY JUN

POLY SP

POLY STR

PTIL CIL

PTIL CRI

PTIL PUL

PYLA POL

RHIZ PSE

RHYT RUG

SPHA ANG

SPHA CAP

SPHA FUS

SPHA SP

SPHA WAR

SPLA AMP

APLA SPH

TAYL SER
Hylocomium species

Hylocomium splendens

Hypnum pratense

Hypnum revolutum

Jamesoniella autumnalis

Lepidozia reptans

Leptobryum pyriforme

Lophozia guttulata

Lophozia incisa

Lophozia longidens

Lophozia ventricosa

Mnium species

Mnium spinulosum

Mylia anomala

Myurella julacea.

Oncophorus wahlenbergii

Orthotrichum rupestre

Orthotrichum speciosum

Plagiochila asplenoides

Plagiomnium cuspidatum

Plagiomnium drummondii

Plagiomnium medium

Pleurozium schreberi

Pohlia nutans

ALPPolytrichum Alpinum

Polytrichum commune

Polytrichum juniperinum

Polytrichum Species

Polytrichum strictum

Ptilium ciliare

Ptilium crista-castrensis

Ptilium pulcherrimum

Pylaisiella polyantha

Rhizomnium pseudopunctatum

Rhytidium rugosum

Sphagnum angustifolium

Sphagnum capillaceum

Sphagnum fuscum

Sphagnum Species

Sphagnum warnstortii

Splachnum ampullaccum

Splachnum sphaericum

Tayloria serrata
Stair Step Moss

Stiff-leaved Polytrichum

Knight's Plume

Common red sphagnum 
TETR ANG

TETR MIN

TETR PEL

THUI ABI

THUI REC

TIMM AUS

TOME NIT

TORT MUC

TORT RUR

TRIT EXS

\section{LICHENS}

Species Code

BACI SPH

BRYO FRE

BRYO FUS

CETR CUC

CETR ERI

CETR HAL

CETR ISL

CETR NIV

CETR PIN

CLADI SP

CLAD BOT

CLAD CAR

CLAD CEN

CLAD CHL

CLAD COC

CLAD CON

CLAD COR

CLAD DEF

CLAD ECM

CLAD FIM

CLAD GRA

CLAD MIT

CLAD PLE

CLAD PYX

CLAD RAN

CLAD SP

EVER MES

HYPO BIT
Tetraplodon angustatus

Tetraplodon minoides

Tetrphis pellucida

Thuidium abietinum

Thuidium recognitum

Timmia austriaca

Tomenthypnum nitens

Tortula mucronifolia

Tortula ruralis

Tritomaria exsecta

\section{Common Name}

Bacidian sphaeroides

Bryoria fremontii

Bryoria fuscescens

Cetraria cucullata

Cetraria ericetorum

Cetraria halei

Cetraria islandica

Cetraria nivalis

Cetraria pinastri

Cladina Species

Cladonia botrytes

Cladonia carneola

Cladonia cenotea

Cladonia chlorophaea

Cladonia coccifera

Cladonia coniocraea

Cladonia cornuta

Cladonia deformis

Cladonia ecmocyna

Cladonia fimbriata

Cladonia gracilis

Cladonia multiformis

Cladonia pleurota

Cladonia pyxidata

Cladonia rangiferina

Cladonia Species

Evernia mesomorpha

Hypogymnia bitteri 
HYPO PHY

ICMA ERI

LETH VUL

LOBA PUL

PARM ALE

PARM AMB

PARM HYP

PARM SUL

PELT APH

PELT CAN

PELT MAL

PELT POL

PELT SP

PHYS ADS

PLAG SP

PLAT GLA

RAMA FAS

RAMA POL

STER TOM

USNE GLA

USNE HIR

USNE SOR

USNE SUB

USNE SP

XANT POL

XANT STR
Hypogymnia physodes

Icmadophila ericetorum

Letharia vulpina

Lobaria pulmonaria

Parmeliopsis aleurites

Parmeliopsis ambigua

Parmeliopsis hyperopta

Parmelia suleata

Peltigera aphthosa

Peltigera canina

Peltigera malacea

Peltigera polydactyla

Peltigera species

Physicia adscendens

Plagiomnium species

Platismatia glauca

Ramalina fastigiata

Ramalina pollinaria

Stereocaulon tomentosum

Usnea glabrescens

Usnea hirta

Usnea sorediifera

Usnea subfloridana

Usnea species

Xanthoria polycarpa

Xanthoria
Spraypaint Lichen

Lungwort

Green Dog Lichen

Leafy moss 


\section{COMMON PROBLEMS}

\section{Duplicate Tree Numbers}

Try to determine the "oldest" tree and assume that is the initial tagged tree. If this can't be done, assume the tree with the largest $\mathrm{DBH}$ and/or height is the original tree. The condition and age of the tree tag may give a clue as to what tree was originally tagged as well. Number the other tree with the next available sequential number.

Past crews would also assign a sapling number to a seedling that has grown to $1.1 \mathrm{~cm} \mathrm{DBH}$. If it is certain that 2 different numbers were used on the same stem, assume the tree is the one with the lower number (regen number).

In all cases fully document this in the comments column beside the appropriate tree(s).

Establishment crews would also rarely follow the proper initial numbering sequence in the regen plots. Use extreme care when measuring these plots.

\section{RECORDING DATA}

All measurements taken on these plots must be recorded on the appropriate tally sheets. Data entered on the sheets is later entered into a computer so legibility is very important. All header lines must be completed.

1) All letters must be capitalized.

2) Use only those species codes listed in Appendix 6.1 and 6.2.

3) Asterisks, numeric characters in alphabetic fields (e.g. B3 in the species columns) and alphabetic characters in numeric fields (e.g. $\mathrm{H}$ in DBH columns) are not acceptable.

4) Comments are written in the shaded areas only. Comments written elsewhere on the tally sheets are not acceptable.

5) Alphabetic characters that are commonly illegible are:

$\mathrm{N}$ that looks like $\mathrm{W}$

$C$ that looks like $\mathrm{L}$ or $\mathrm{O}$

$D$ that looks like $P$ or $O$

I that looks like T or L

6) Numeric characters that are commonly illegible are:

2 that is 'looped' and looks like 0

6 and 9 that looks like 0 or 4

0 incompletely closed and looks like 6

5 that looks like S

7 and 1 mistaken for each other

Scientific (European) 7 is not acceptable

The number is written as open (i.e. four not 4). 


\section{GENERAL INFORMATION (CSTM 101)}

$\begin{array}{cl}\text { Column } & \text { Name } \\ 1 & \text { Record Type } \\ & \\ 3 & \text { Group Number } \\ 5 & \text { Plot Number } \\ 8 & \text { Plot Type } \\ 10 & \text { Year } \\ 12 & \text { Month } \\ 14 & \text { Day }\end{array}$

15

16

\section{Data Entry}

03 - cruise tally

04 - cruise vegetation

05 - plot vegetation

06 - regeneration (planted \& natural)

61 - regen height class tallies

07 - sapling

08 - tree plot

09 - plot retreatment

1 record type per page.

2 digits, right justified.

5 digits - zero fill, right justified.

Leave blank.

Last 2 digits of year are recorded e.g. 1996 recorded as 96 .

Right justified, zero filled e.g. June is recorded as 06 .

Right justified zero filled. Note the date is the same on all tally sheets even if the plot took several days to remeasure with the exception of the vegetation tally sheet CSTM 102, which the actual date is recorded.

Full crew names, initials are not acceptable e.g. John Smith, Mary Jones.

Fill in the number of regeneration plot in which pinned seedlings are found. For planted seedlings outside the regen plots but within the pre 1993 sapling plot, code regen \# as 5. 


\section{$\underline{\text { Column }}$}

17

21

23

27

35

36

42

45
Height

$\underline{\text { Name }}$

Tree Number

Species

Diameter

Crown Class

Condition Codes

Azimuth

Distance

\section{Data Entry}

Fill in as required.

Recorded as 2 capitalized letters as given in Appendix 6.1.

Numeric, right justified, tree must be $>1.3 \mathrm{~m}$ tall to have diameter recorded.

Measurements to nearest millimeter.

Numeric right justified.

Regen \& sapling exclude current years growth and measure to nearest centimeter.

Trees $(>9.1 \mathrm{~cm} \mathrm{DBH})$ - measure and record total height for all trees. Refer to Appendix 6.3

Crown class is recorded on trees and saplings as one letter (D, C, I, S or O). Refer to Appendix 6.9

Left justified, recorded as a 2 digit number. Do not zero fill e.g. a leaning tree with conks is recorded as 51,58 , blank. If a tree has no defect it is recorded as ' 00 '. Refer to Appendix 6.5

Right justified, recorded as $10-360^{\circ}$. Only $360^{\circ}$ can be used, not $0^{\circ}$.

Right justified, measured to nearest decimeter on all saplings and trees (standing dead as well). Record declination in comments. Note that 2 stems cannot have identical azimuths and distances.

\section{GENERAL INFORMATION (CSTM 100)}

Columns Refer to section 4.1

1-16 Refer to section 4.1

17 Species - recorded as 2 capitalized letters as given in Appendix 6.1

19-54 Height classes - recorded to nearest centimeter, excluding current years growth. Right justified, zero filled. 
18. EXAMPLE OF A TIE PLATE

\section{FOREST MANAGEMENT PROJECT}

PERMANENT SAMPLE PLOT NO $\mathbf{4 5 6}$

TIE POINT ' $\underline{A}$ ' 75 M $\underline{C ~} 180^{\circ}$ TO $\underline{\text { P.C. }}$

LS. SEC. TWP. RGE. W. MER.

$\begin{array}{lllll}1 & 36 & 101 & 19 & 4\end{array}$

FOR MORE INFORMATION CONTACT ALBERTA FOREST SERVICE

ranger station at Fort $\mathcal{M}$ cMutray

OR FO $\triangle$ ST MEASUREMENT AT 427-8474 




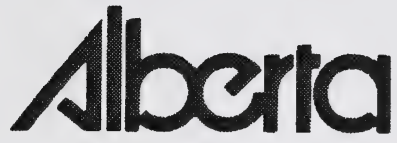

SUSTAINABLE RESOURCE

DEVELOPMENT

\section{PSP MANUALS MASTER \\ TABLE OF FIGURES \\ March 2005}

Public Lands and Forests Division

Forest Management Branch

$8^{\text {th }}$ Fl. 9920-108 Street

Edmonton, $A B$

T5K 2M4

Phone: (780) $427-8474$

Or visit the website: http://www3.gov.ab.ca/srd/forests/psp 



\section{TABLE OF FIGURES}

FIGURE $2.1 \quad$ PLOT LAYOUT. 1

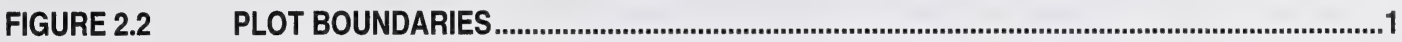

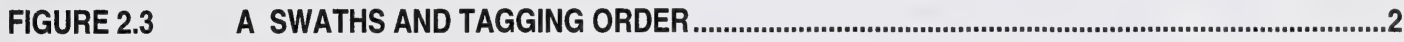

FIGURE 2.3B AN EXAMPLE OF NUMBERING ON TREE TAG ..................................................................

FIGURE 2.4 DETERMINING POINT OF GERMINATION AND BREAST HEIGHT .........................................

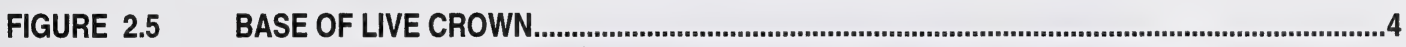

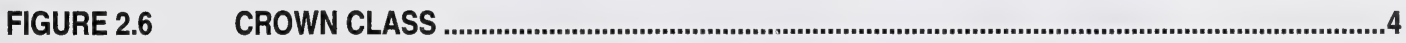

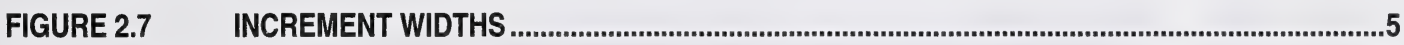

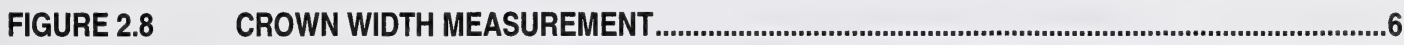

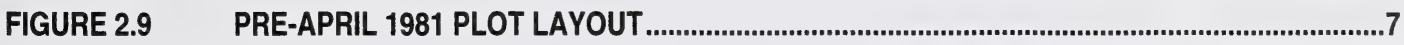

FIGURE 2.10 GROUP PLOT MAINTENANCE FORM

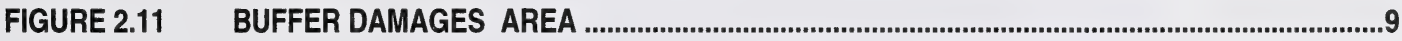

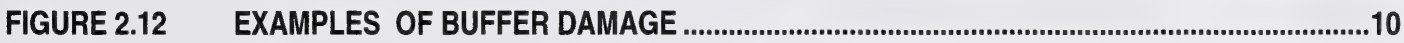

FIGURE 2.13 DATA ENTRY ON PSP HEADER SHEET ..........................................................................11

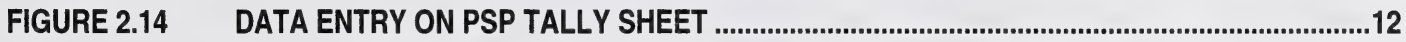

FIGURE 2.15 DATA ENTRY ON REGENERATION TALLY SHEET ...........................................................13

FIGURE $3.1 \quad$ PSP TREE TALLY CHECK SHEET.................................................................................14

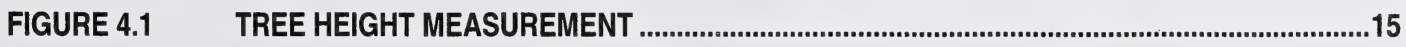

FIGURE 4.2 HEIGHT MEASUREMENT OF LEANING TREES.....................................................................16

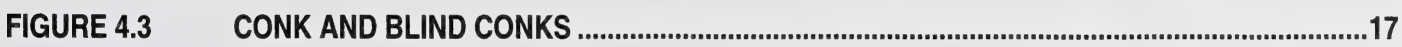

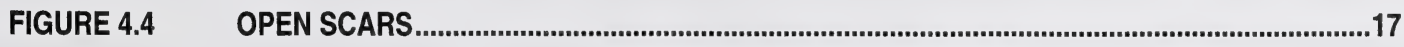

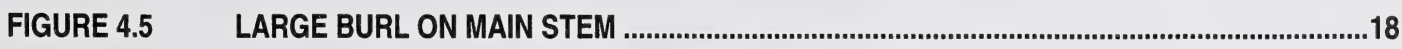

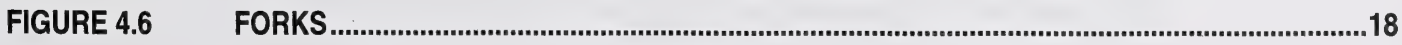

FIGURE $4.7 \quad$ PRONOUNCED CROOK ...............................................................................................19

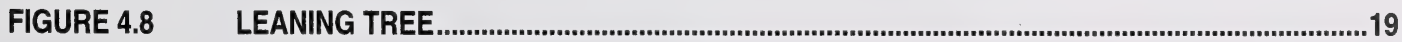


FIGURE 4.9

ATROPELLIS CANKER

FIGURE 4.10 WITCHES ON SPRUCE

FIGURE 4.11 MISTLETOE .21

FIGURE 4.12 INSTRUCTIONS AND EXAMPLE OF THE USE OF THE 6 .22

CLASS MISTLETOE RATING SYSTEM (HAWKSWORTH 1961, 1977),................................................................22

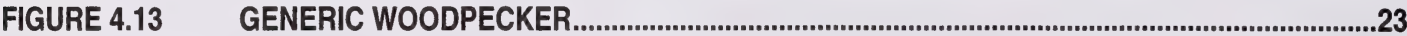

FIGURE $4.14 \quad$ YELLOWBELLIED SAPSUCKER FEEDING ...........................................................................23

FIGURE 4.15 SMALL MAMMA L FEEDING ON TREE BOLE .........................................................................24

FIGURE $4.16 \quad$ EXCAVATIONS BY WOODPECKERS

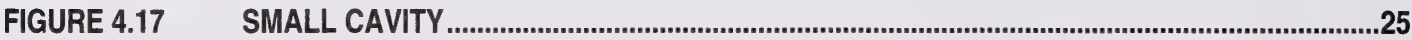

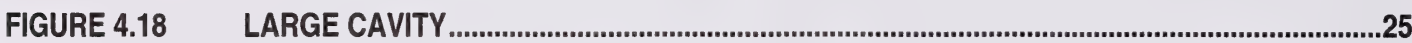

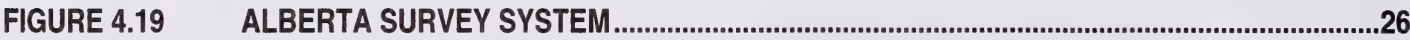

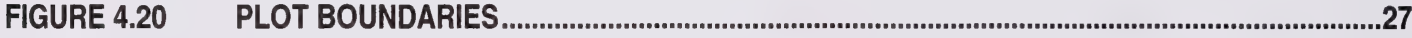

FIGURE 4.21 STAND DYNAMICS PLOT LAYOUT

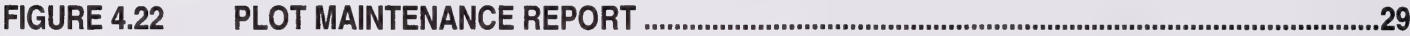

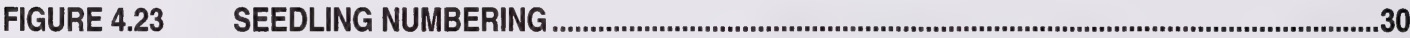

FIGURE 4.24 STAND DYNAMICS TALLY SHEET (CSTM 101) RECORD TYPE 6 .........................................31

FIGURE 4.25 STAND DYNAMICS TALLY SHEET (CSTM 101) RECORD TYPE 7 (SAPLINGS).....................32

FIGURE 4.26 STAND DYNAMICS TALLY SHEET (CSTM 101) RECORD TYPE 8 (TREE PLOT).................33

FIGURE 4.27 STAND DYNAMICS REGENERATION HEIGHT CLASS RECORD (CSTM 100) RECORD TYPE 61

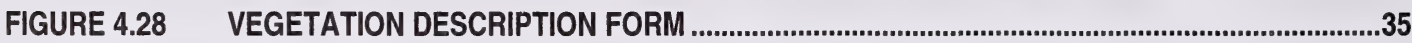

FIGURE 4.29 PLOT RETREATMENT REPORT (RECORD TYPE 9).............................................................36

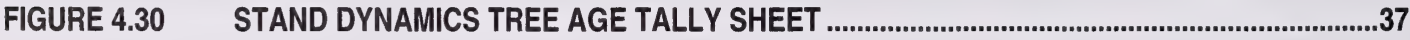

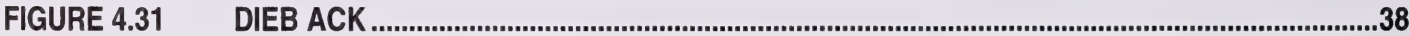




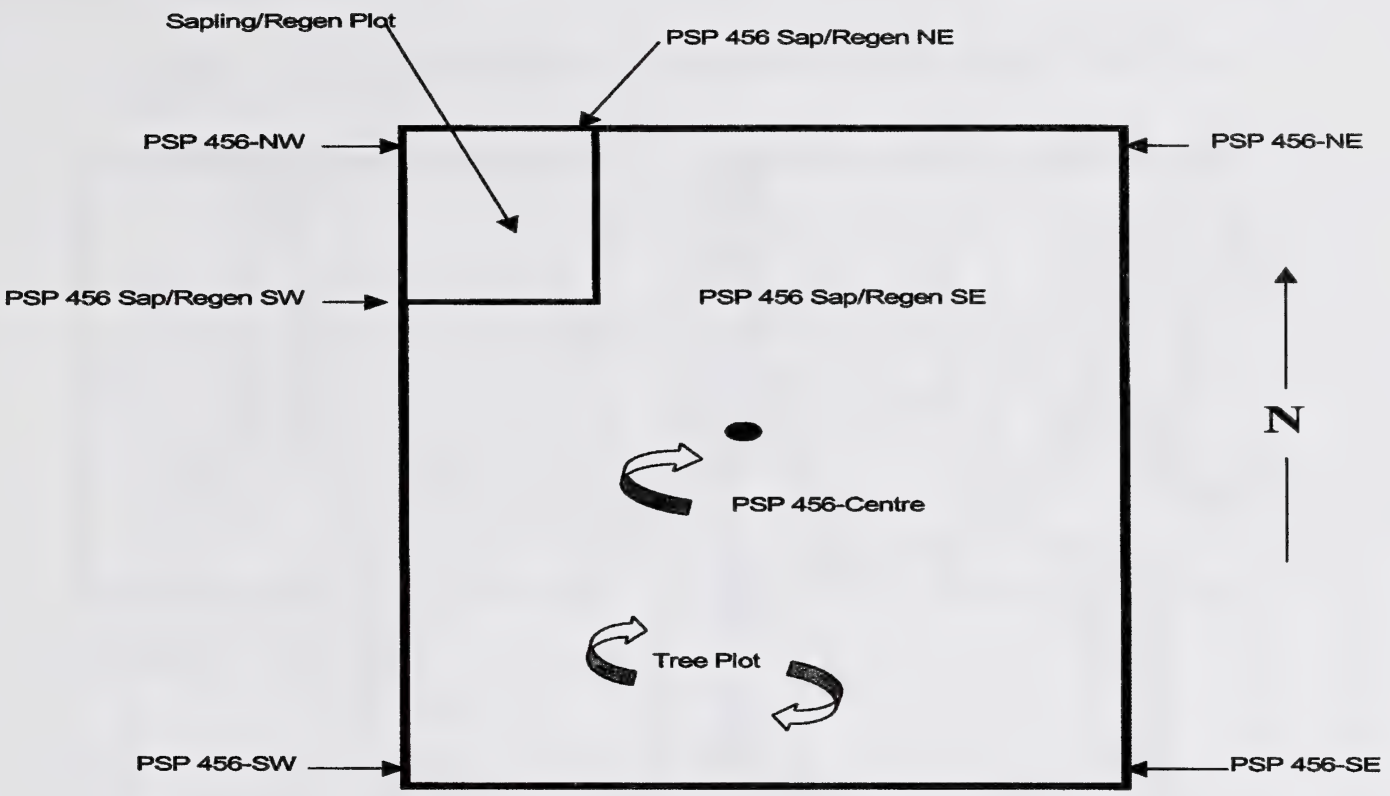

FIGURE $2.1 \quad$ PLOT LAYOUT

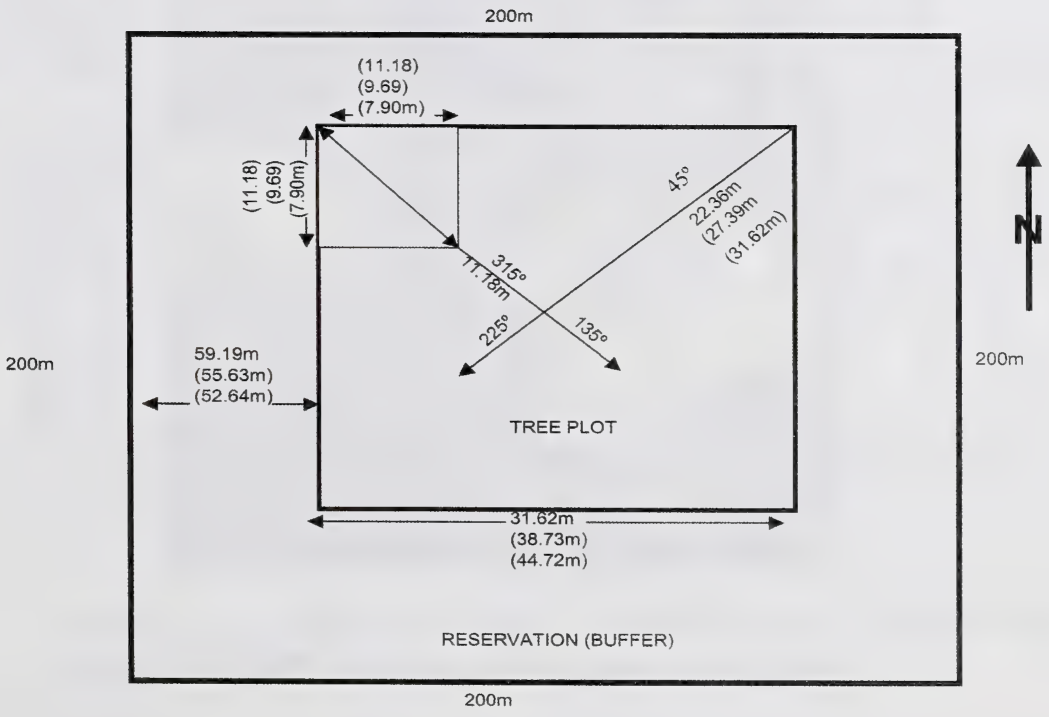

FIGURE 2.2 PLOT BOUNDARIES 


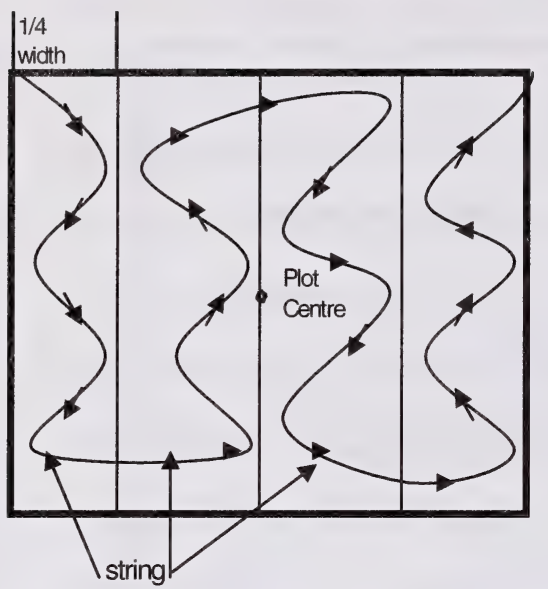

Tree tagged and nailed on north side of tree at DBH

FIGURE 2.3 A SWATHS AND TAGGING ORDER

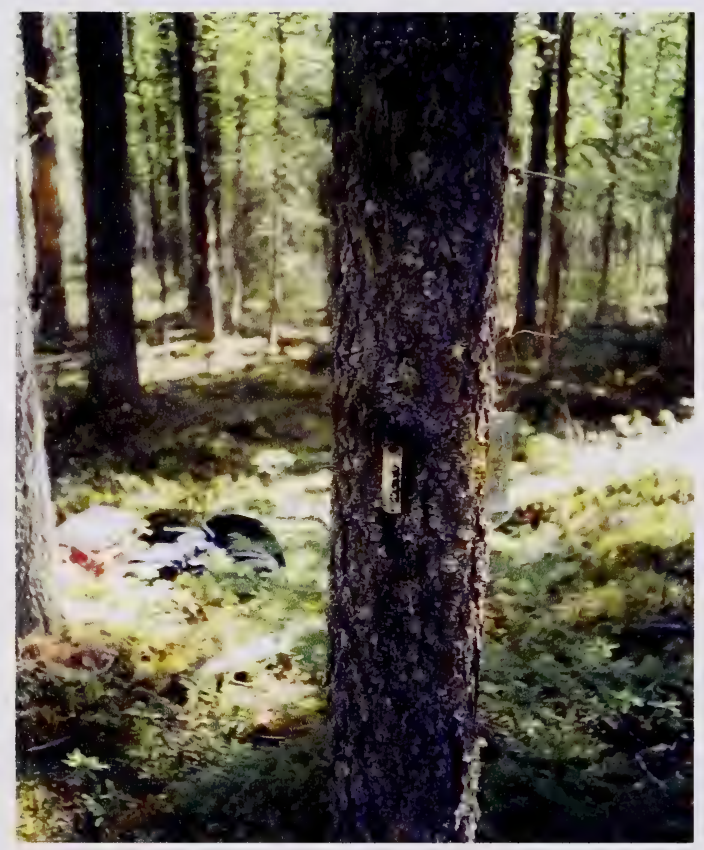

FIGURE 2.3B AN EXAMPLE OF NUMBERING ON TREE TAG 
Trees forked below $1.3 \mathrm{~m}$ are treated as two separate stems and are tagged and tallied as such.

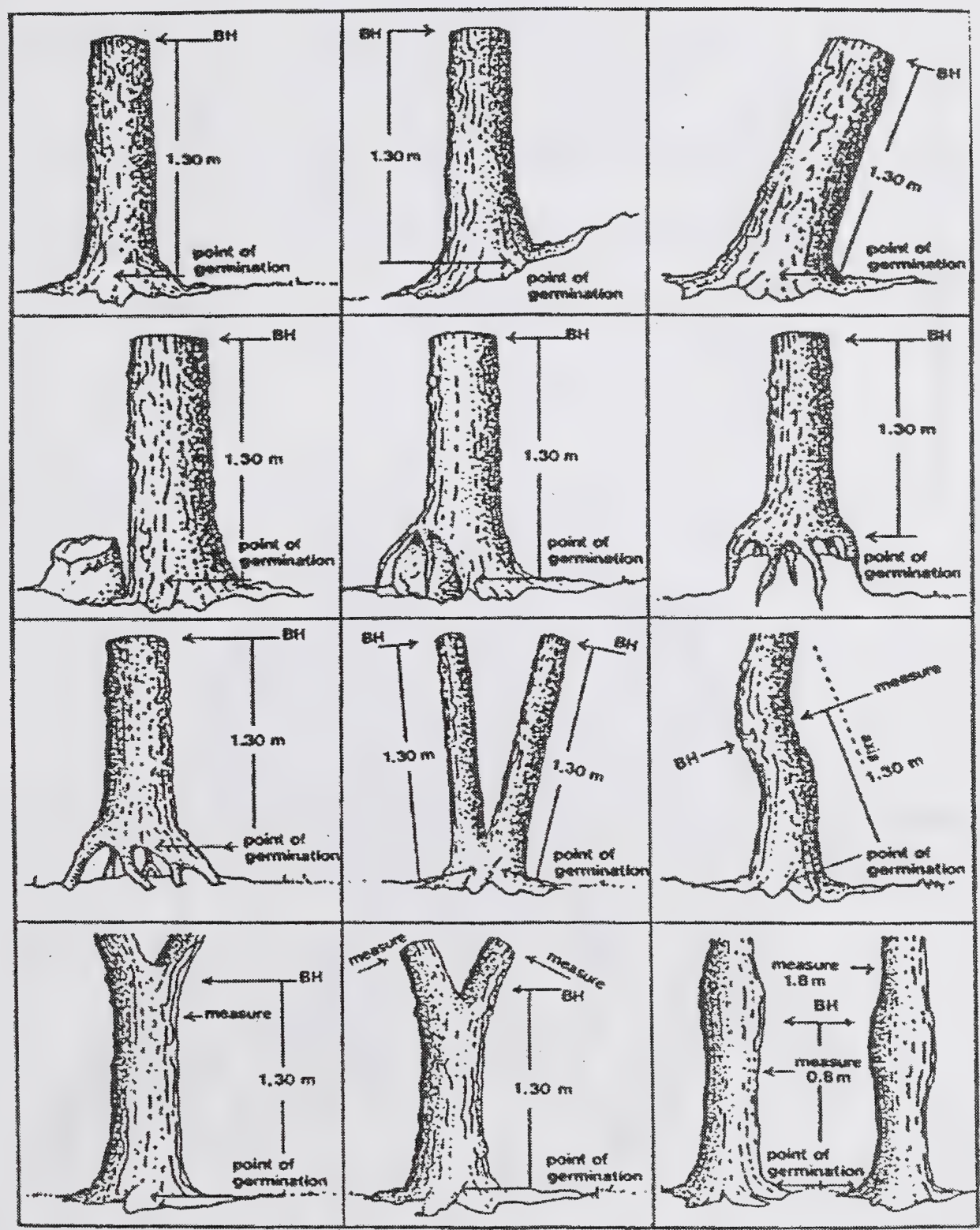

FIGURE 2.4 DETERMINING POINT OF GERMINATION AND BREAST HEIGHT 


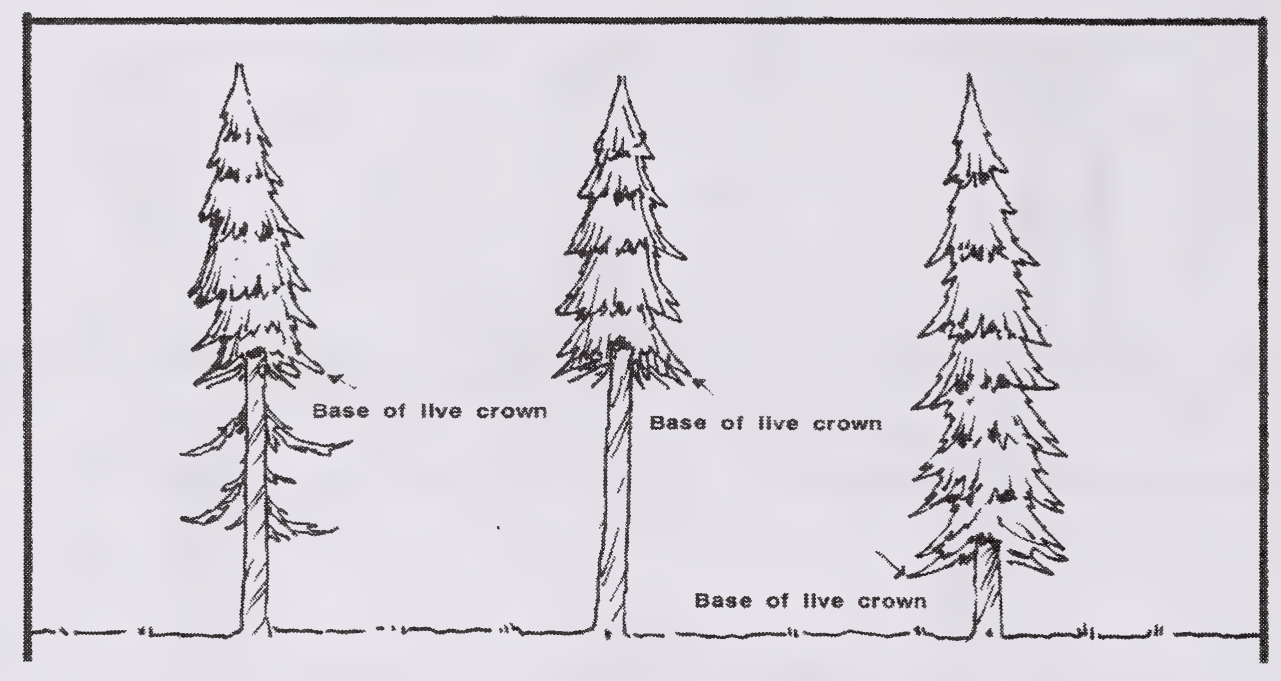

FIGURE 2.5 BASE OF LIVE CROWN

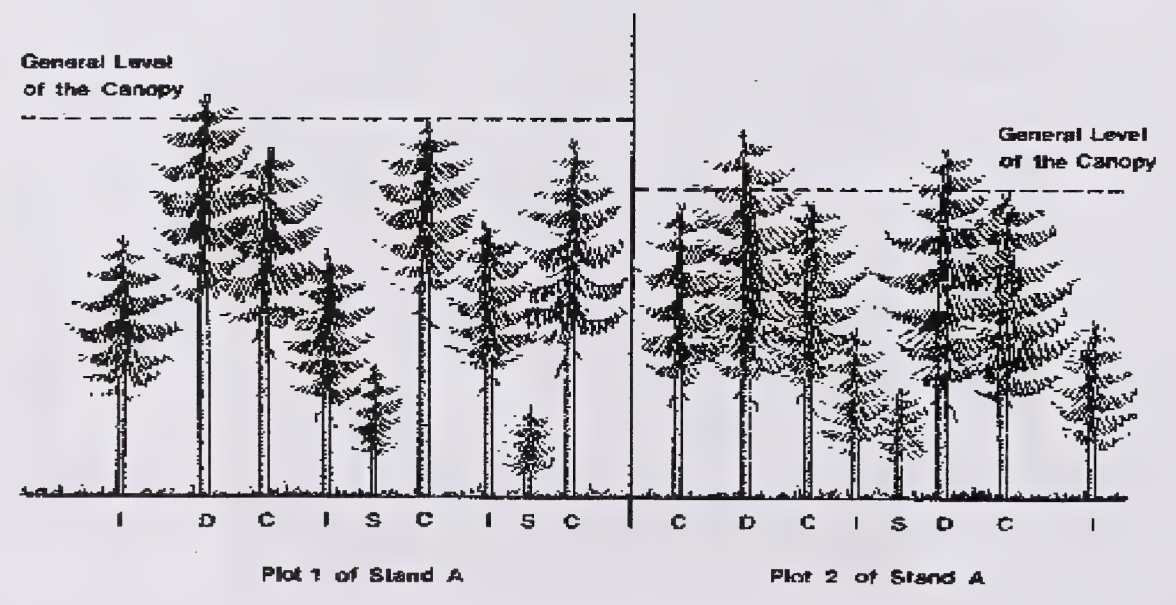

FIGURE 2.6 CROWN CLASS 
Note: a crown class is recorded for dieback/dead top (code 16). The top of the live foliage is used to determine crown class in this case.

\begin{tabular}{|c|c|}
\hline D-Dominant & -crowns extend above the general level of the canopy. \\
\hline C-Codominant & -crowns form the general level of canopy. \\
\hline I-Intermediate & $\begin{array}{l}\text { - crowns below but extending into the bottom of the general level of the } \\
\text { canopy. }\end{array}$ \\
\hline S - Suppressed & -crowns entirely below the general level of the canopy. \\
\hline O-Open grown & if the trees branches does not interact with another trees branches. \\
\hline
\end{tabular}

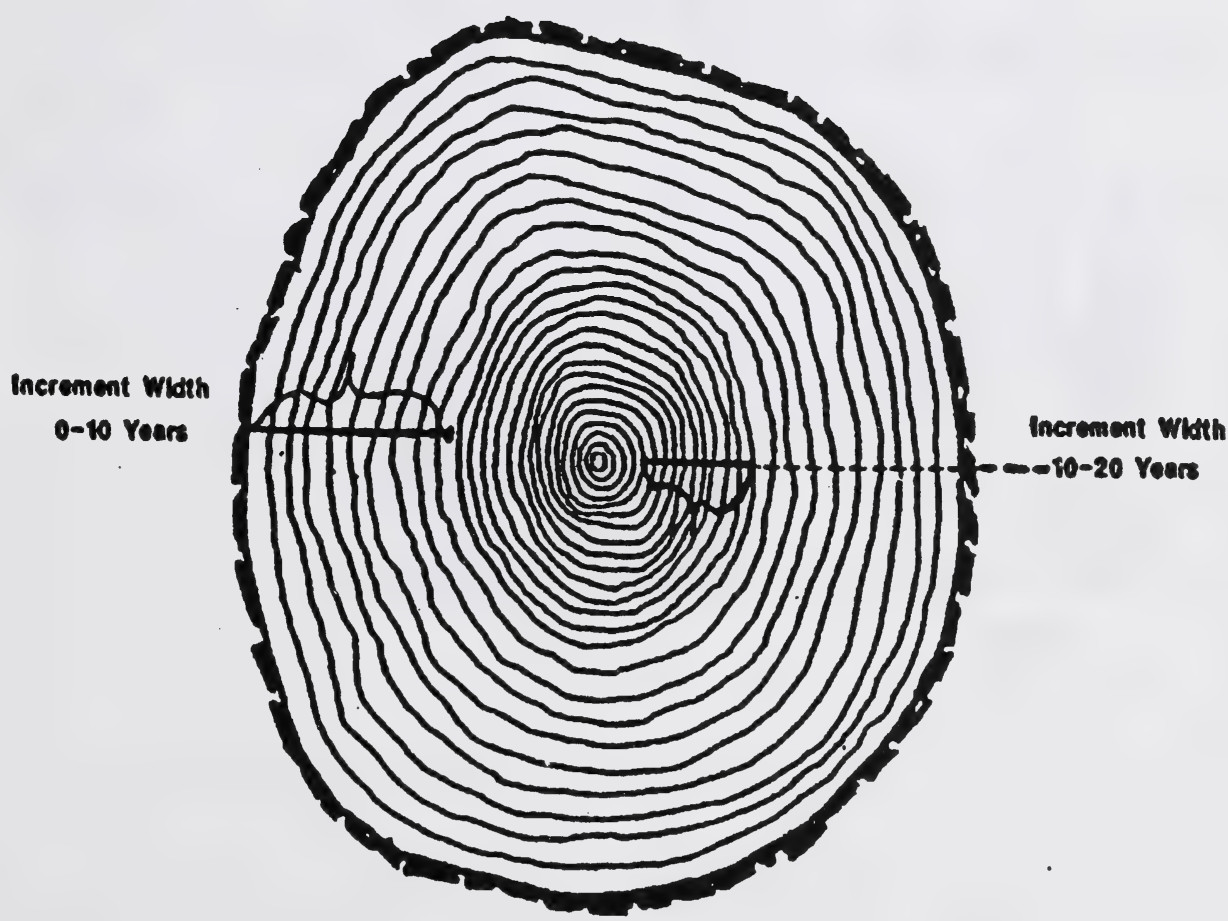

FIGURE 2.7 INCREMENT WIDTHS 


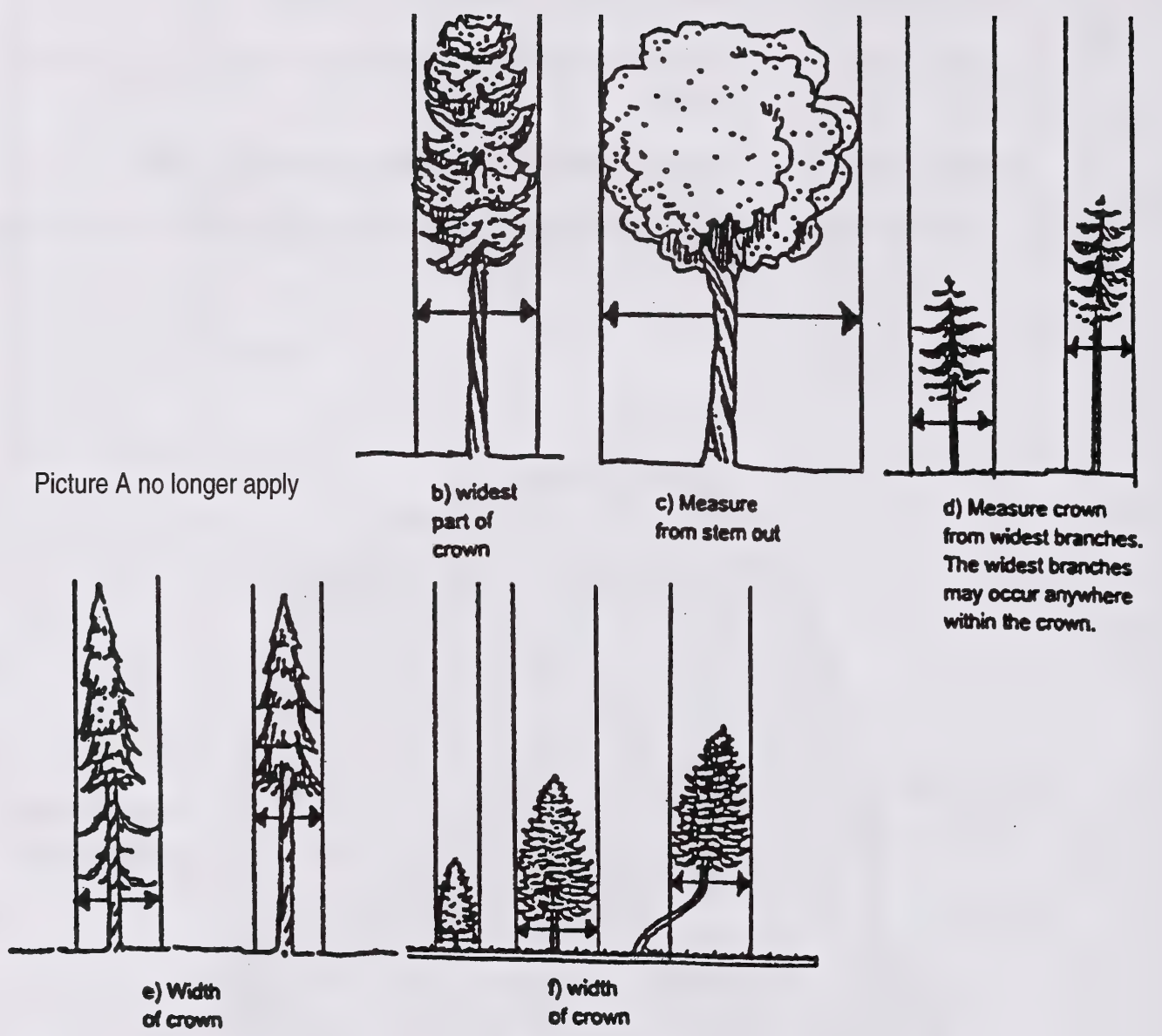

FIGURE 2.8 CROWN WIDTH MEASUREMENT 


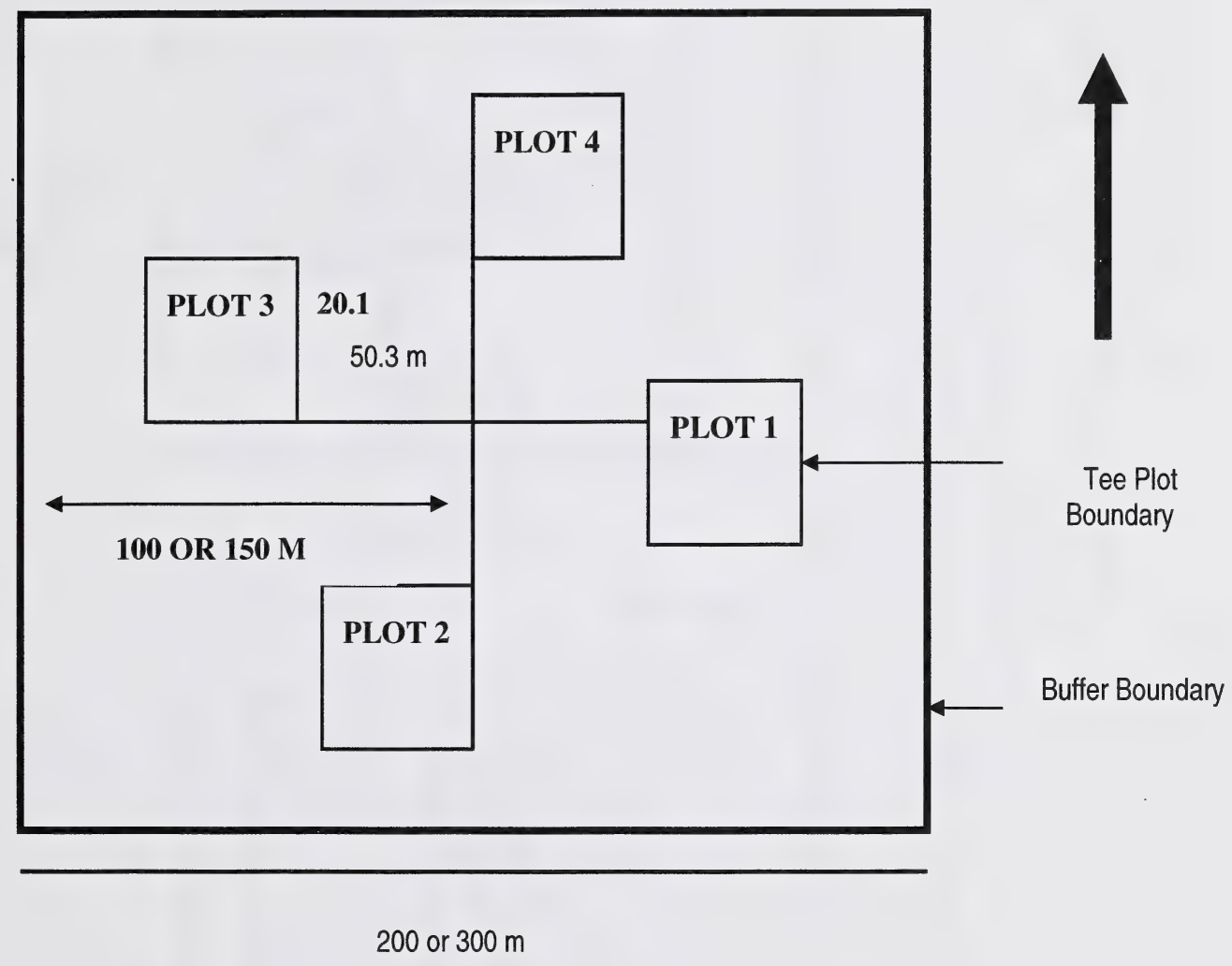

FIGURE 2.9 PRE-APRIL 1981 PLOT LAYOUT 

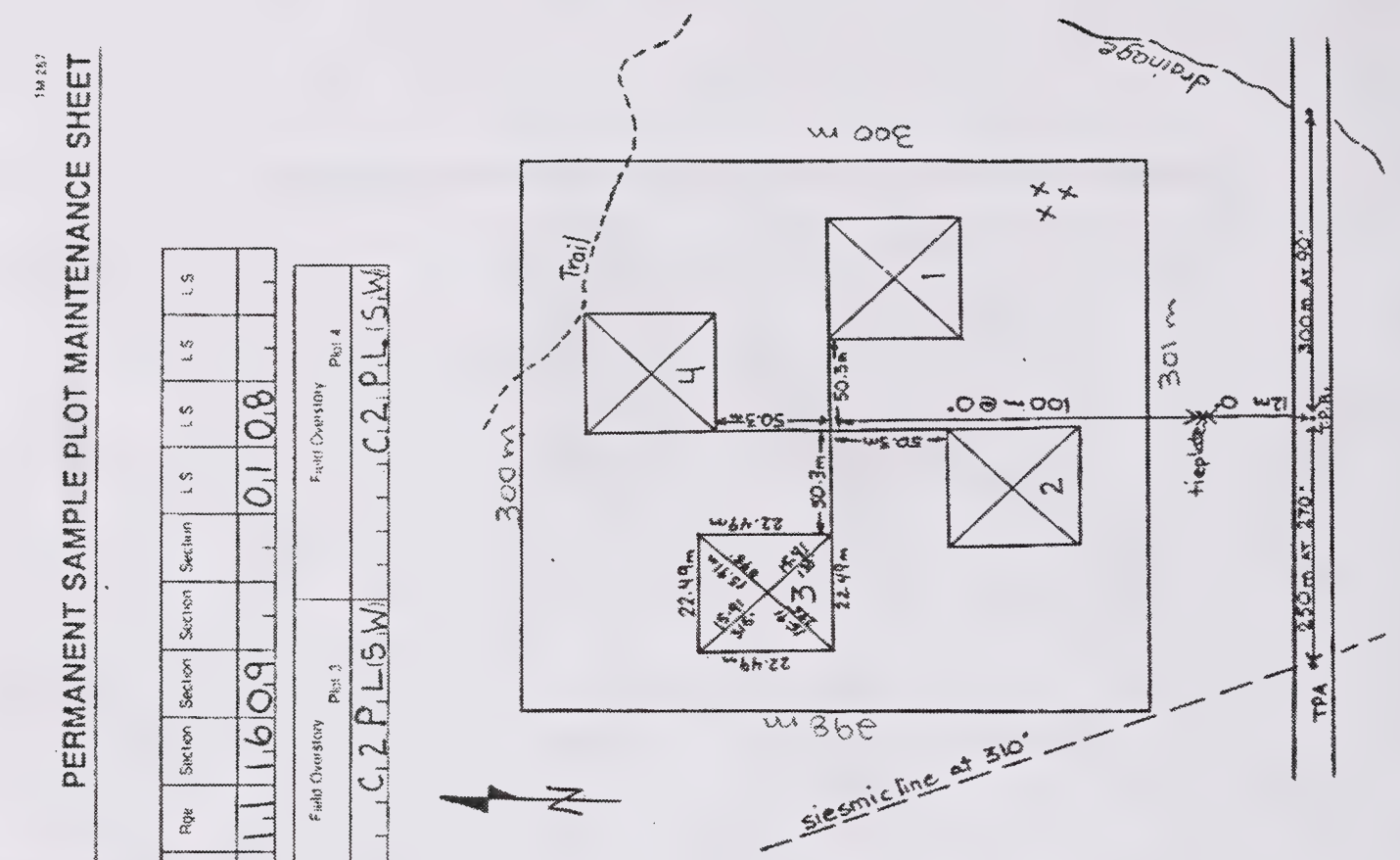

FIGURE 2.10 GROUP PLOT MAINTENANCE FORM 

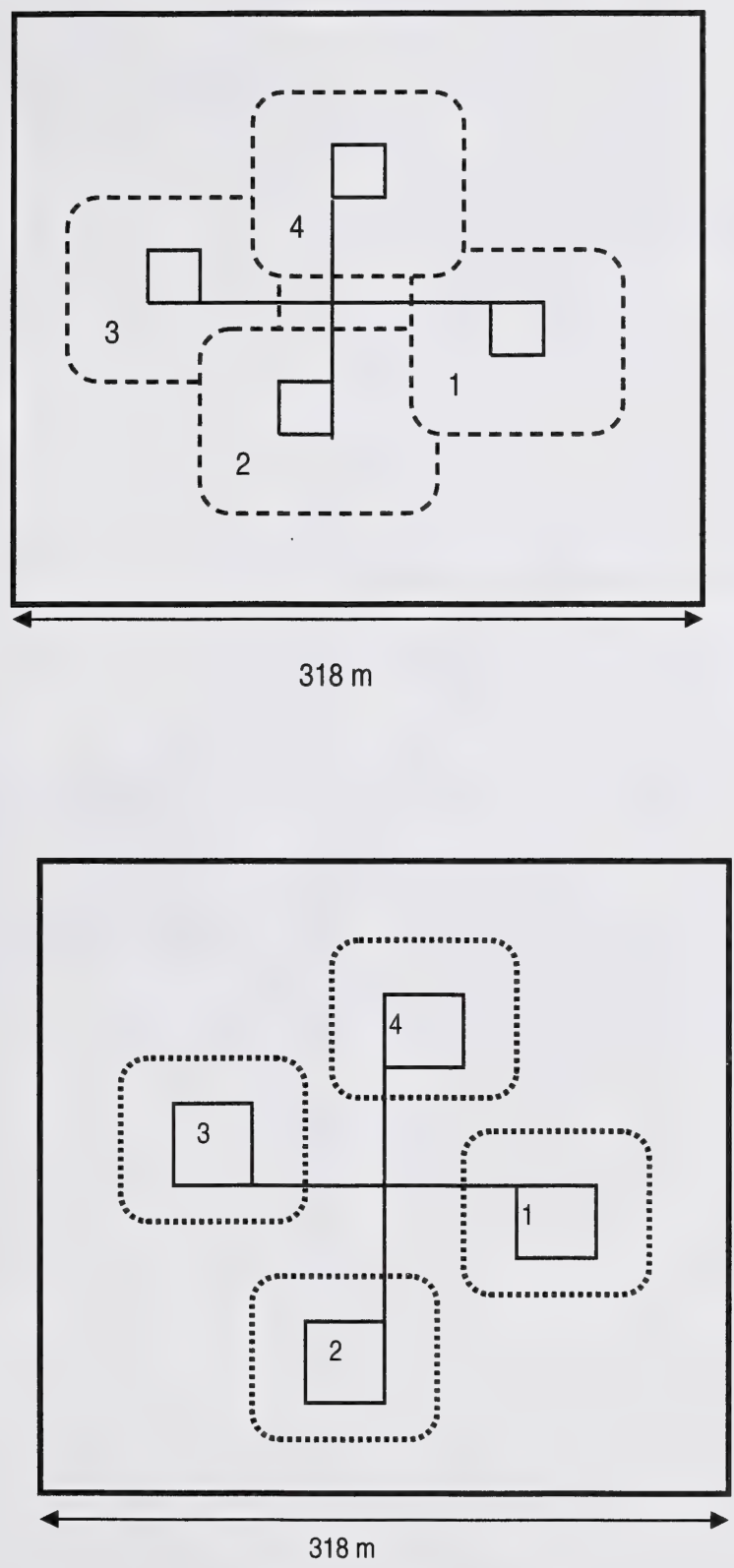

FIGURE 2.11 BUFFER DAMAGES AREA 


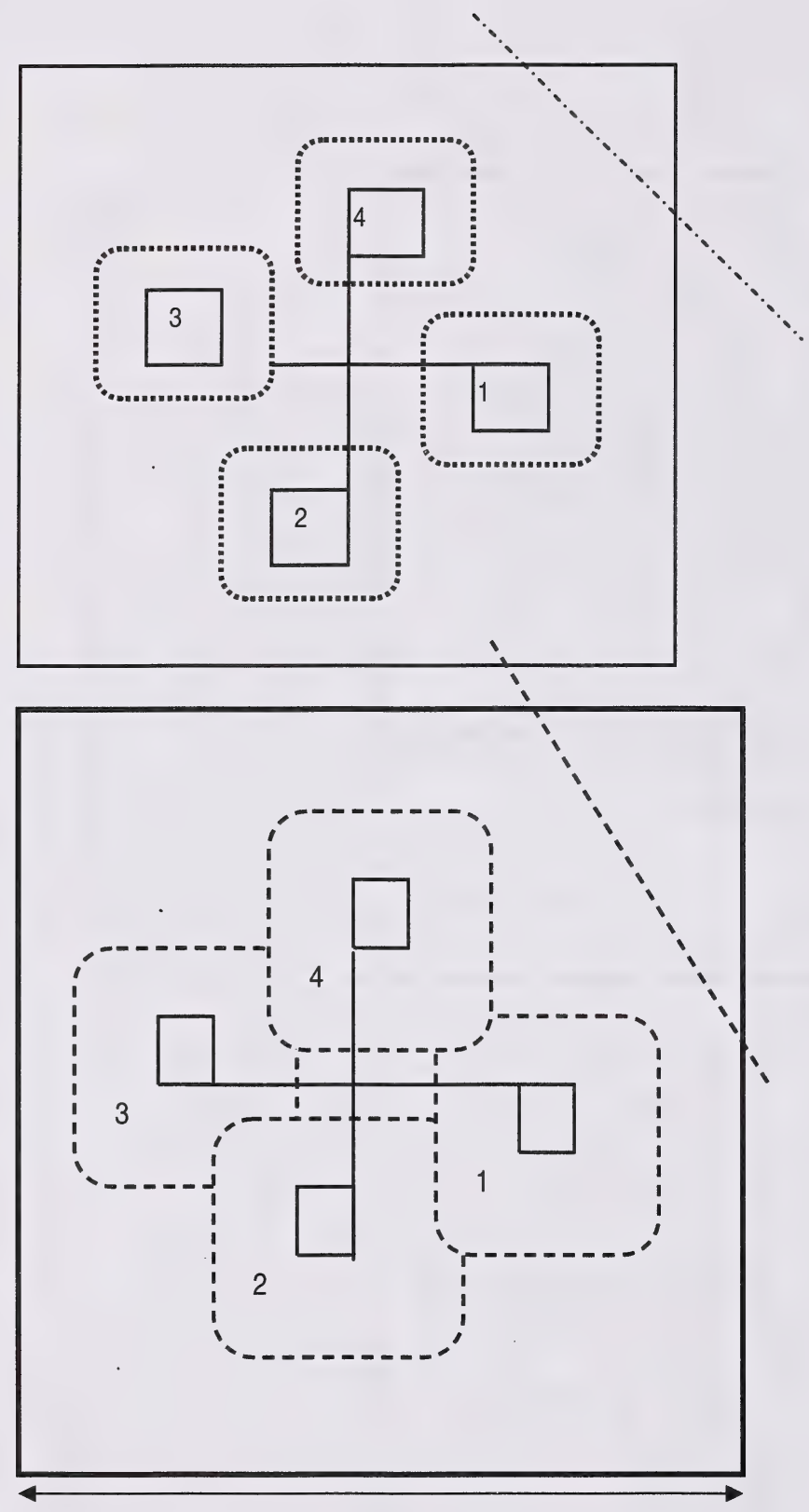

The seismic line, in this example does not come within $20 \mathrm{~m}$ of any of the subplots.

Therefore, all subplots would have a code 6 recorded for buffer damages.

The seismic line, in this example is within $20 \mathrm{~m}$ of subplots 1 and 4 . For these two subplots, a code 3 (manmade damage) is recorded in the buffer damage space. Code 6 is recorded for subplots 2 and 3 as damage is not within those buffer damage zones.

$318 \mathrm{~m}$

FIGURE 2.12 EXAMPLES OF BUFFER DAMAGE 


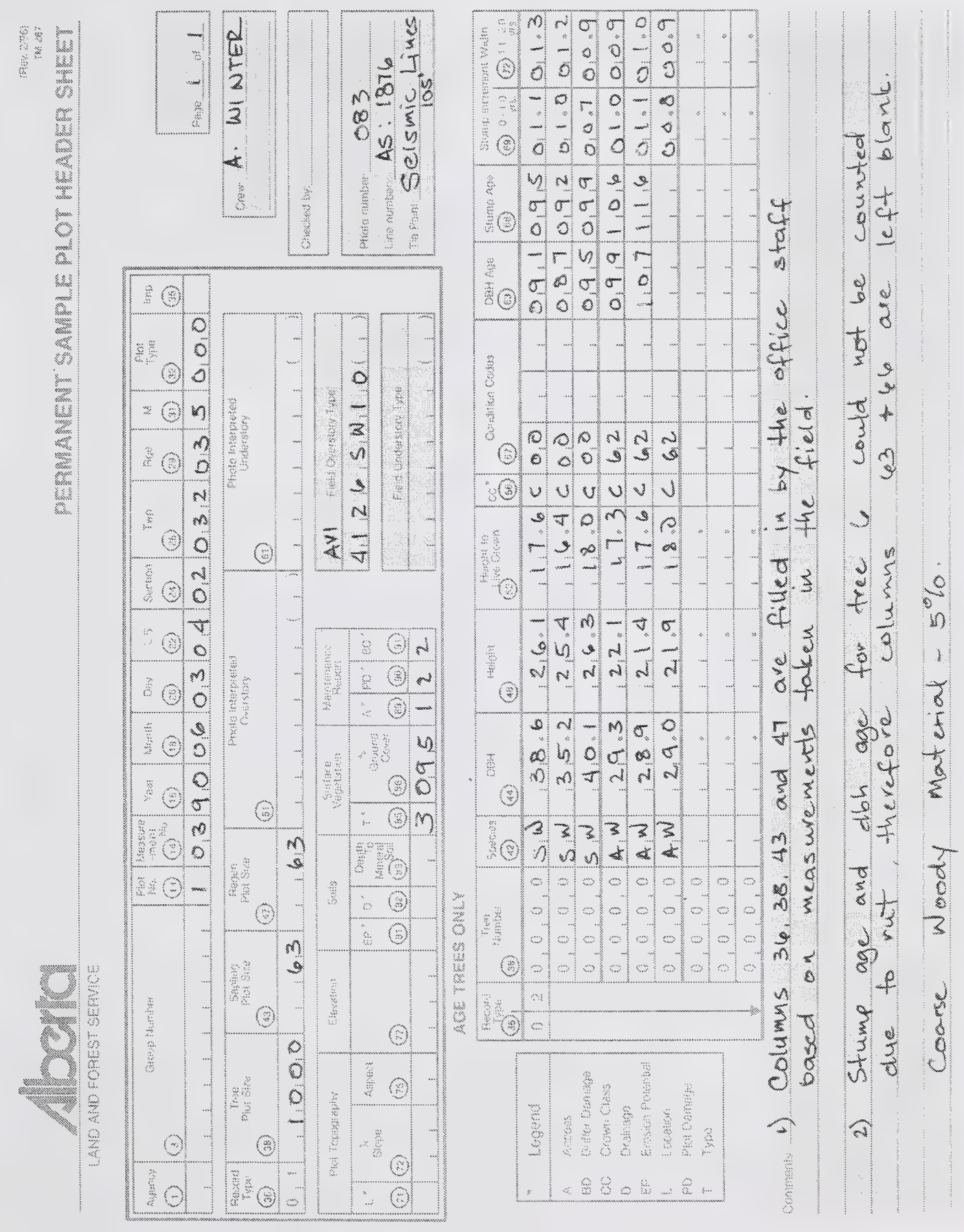

FIGURE 2.13 DATA ENTRY ON PSP HEADER SHEET 


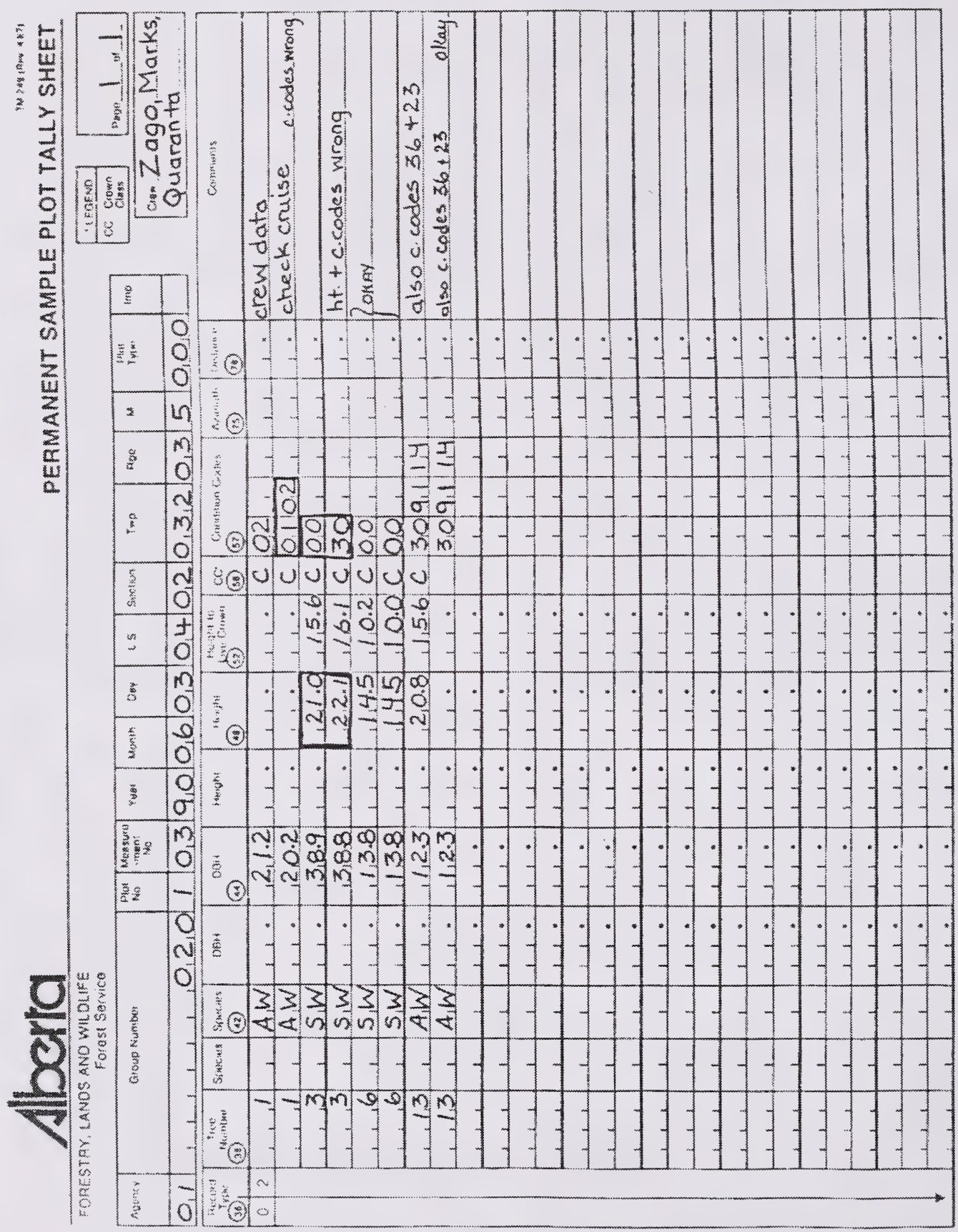

FIGURE 2.14 DATA ENTRY ON PSP TALLY SHEET 

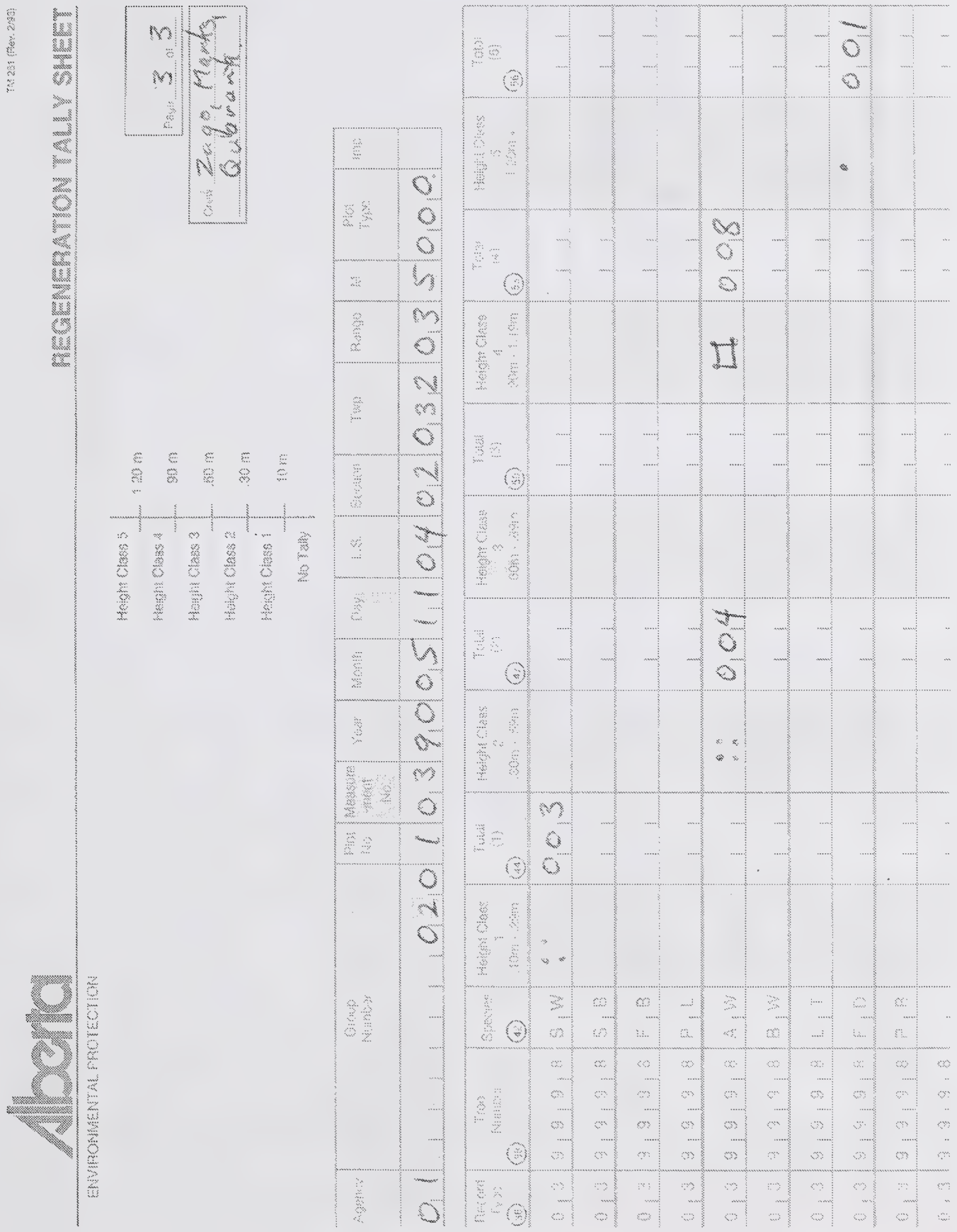

FIGURE 2.15 DATA ENTRY ON REGENERATION TALLY SHEET 


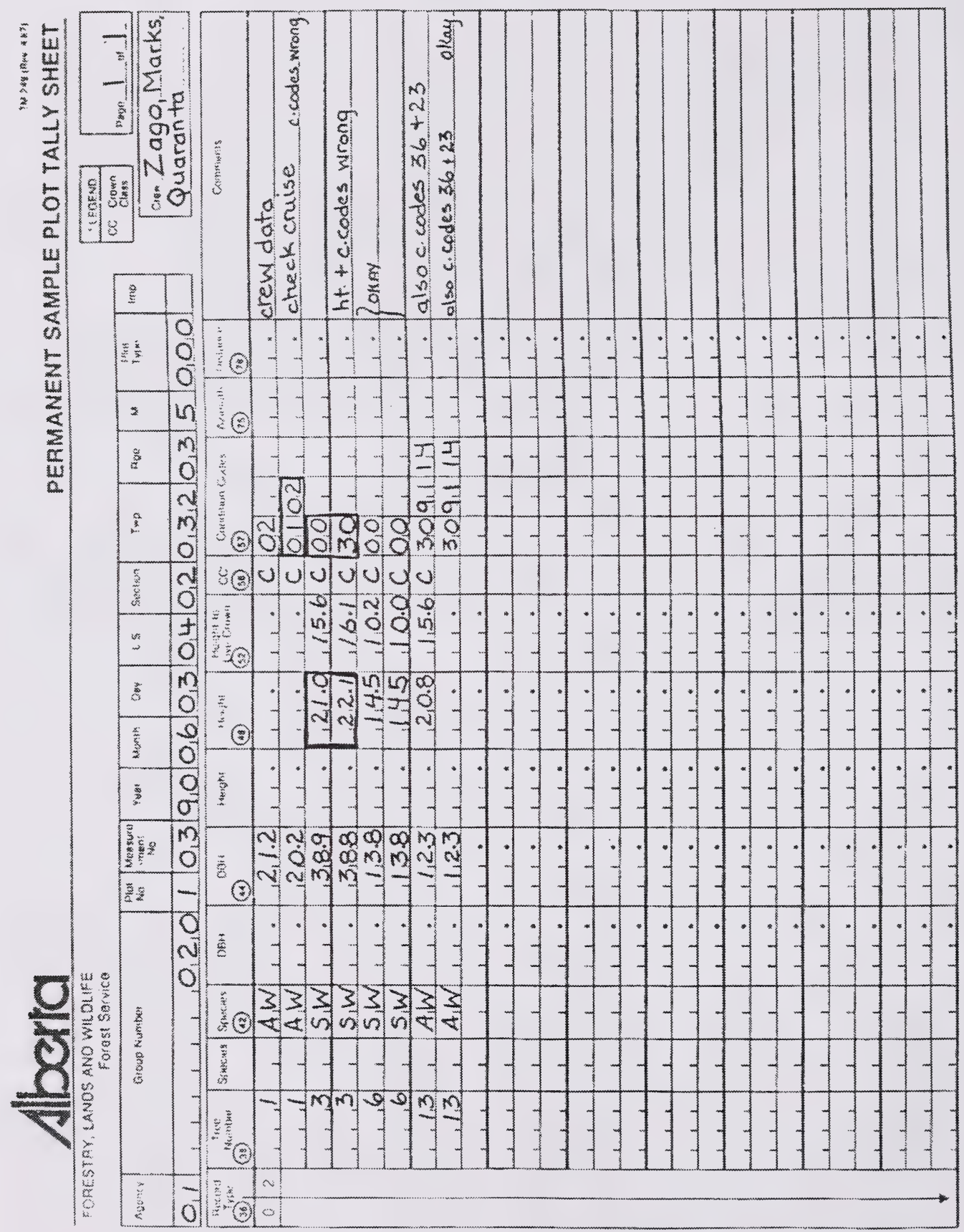

FIGURE 3.1 PSP TREE TALLY CHECK SHEET 

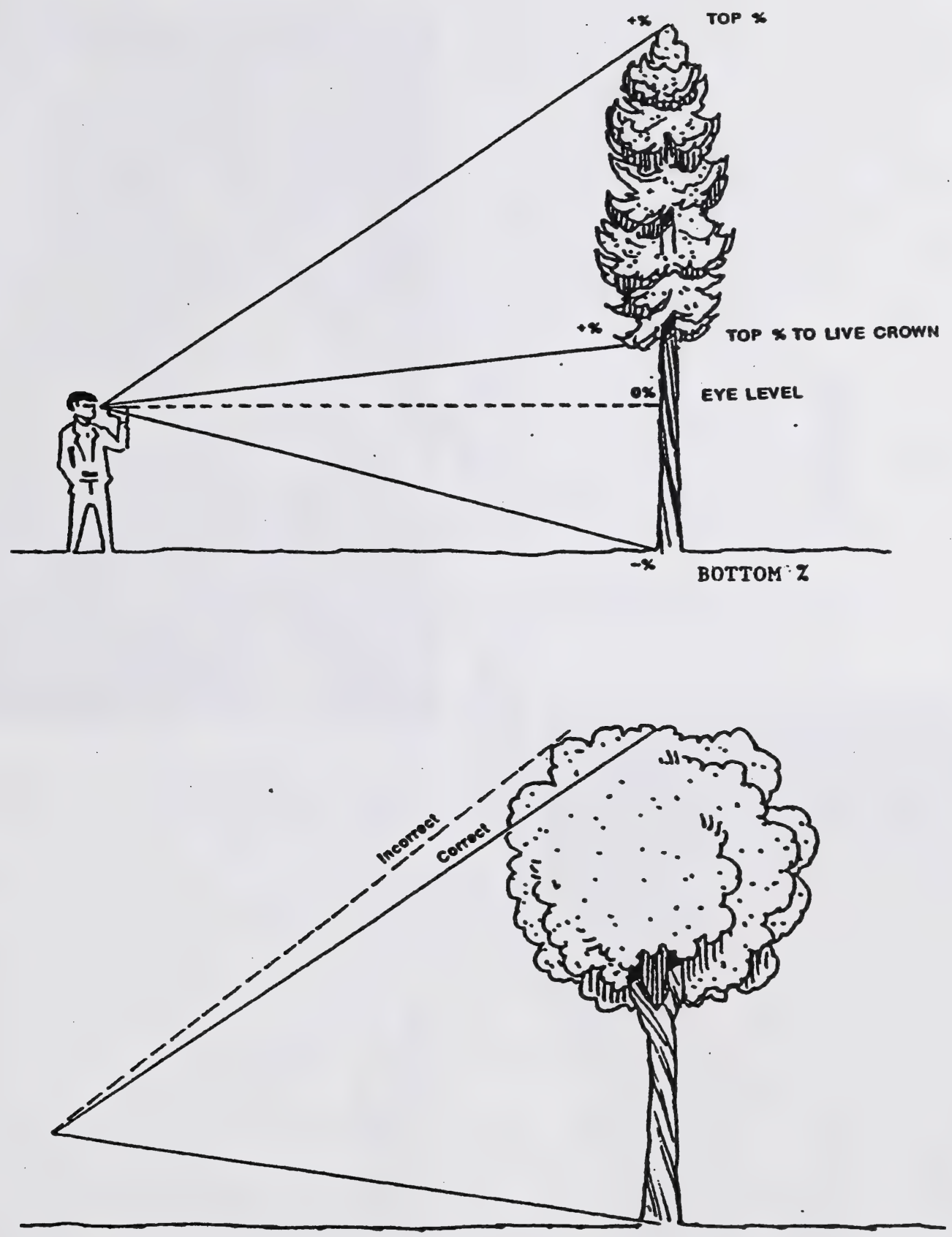

FIGURE 4.1 TREE HEIGHT MEASUREMENT 

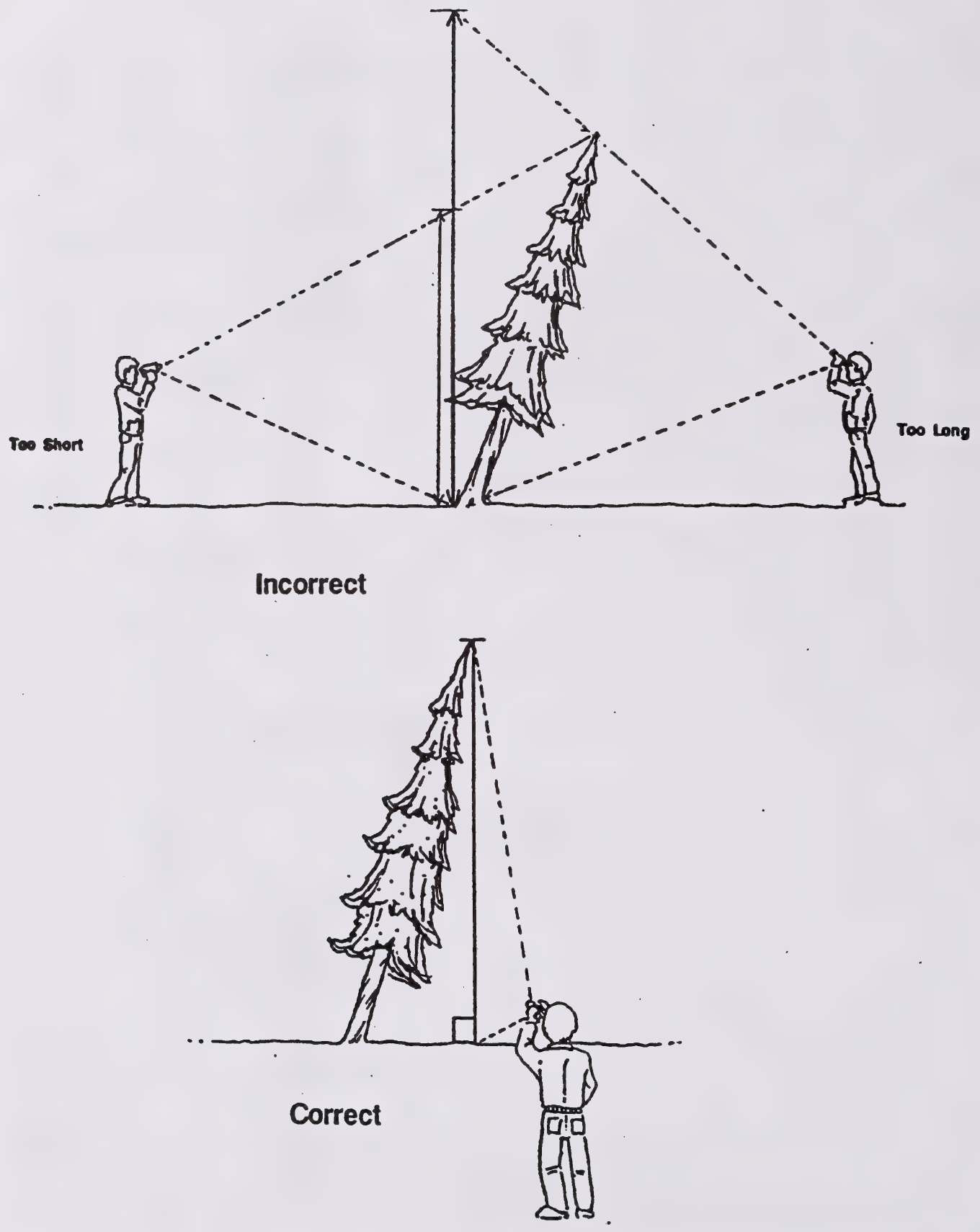

FIGURE 4.2 HEIGHT MEASUREMENT OF LEANING TREES 


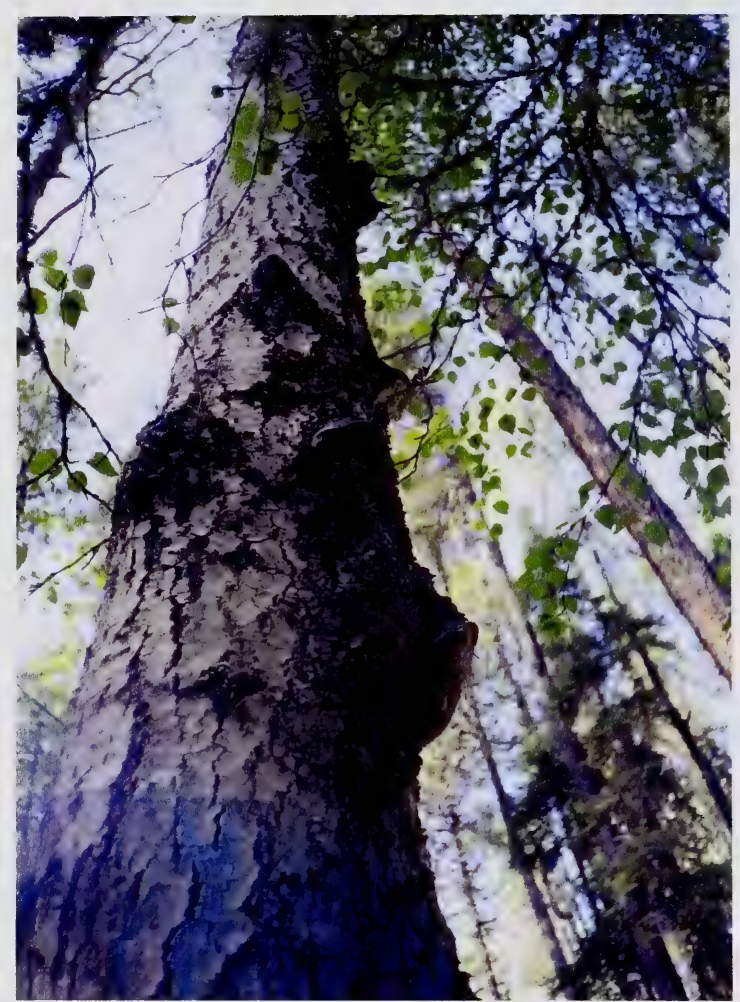

FIGURE 4.3 CONK AND BLIND CONKS
FIGURE 4.4 OPEN SCARS

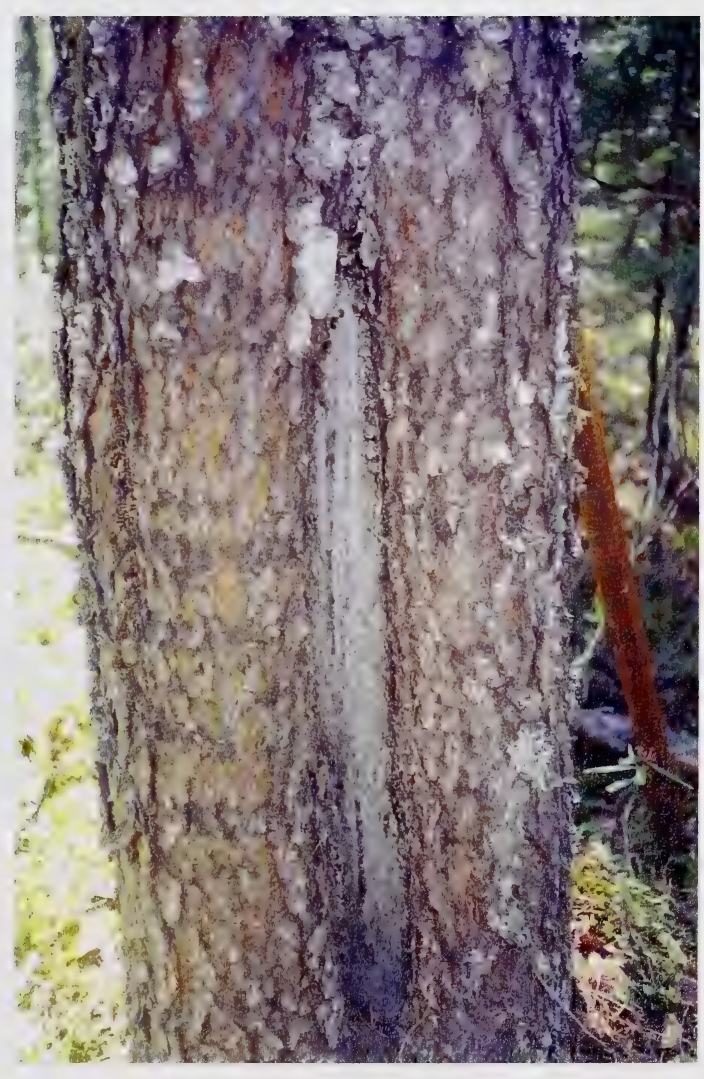

Public Lands and Forests Division 


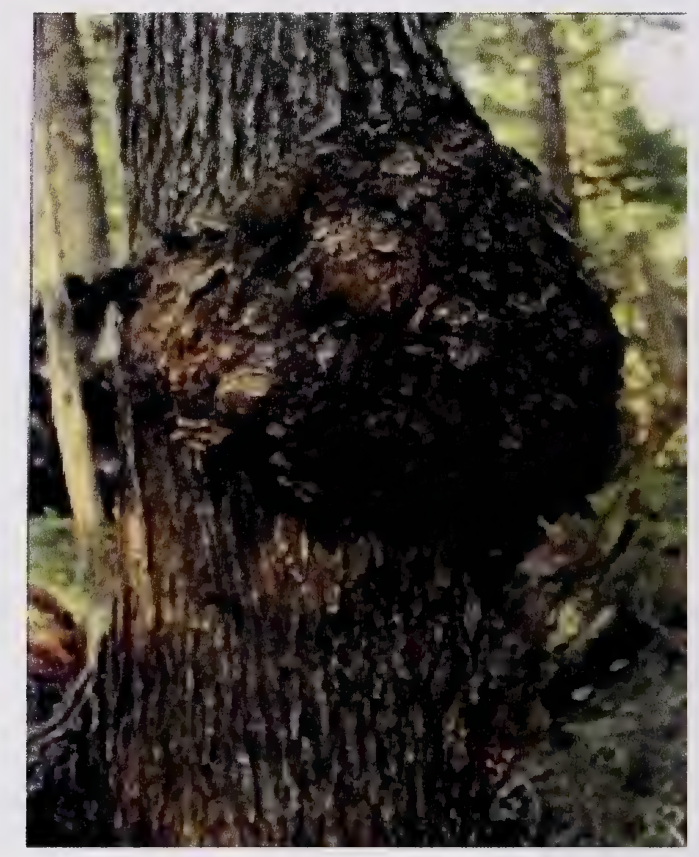

FIGURE 4.5 LARGE BURL ON MAIN STEM
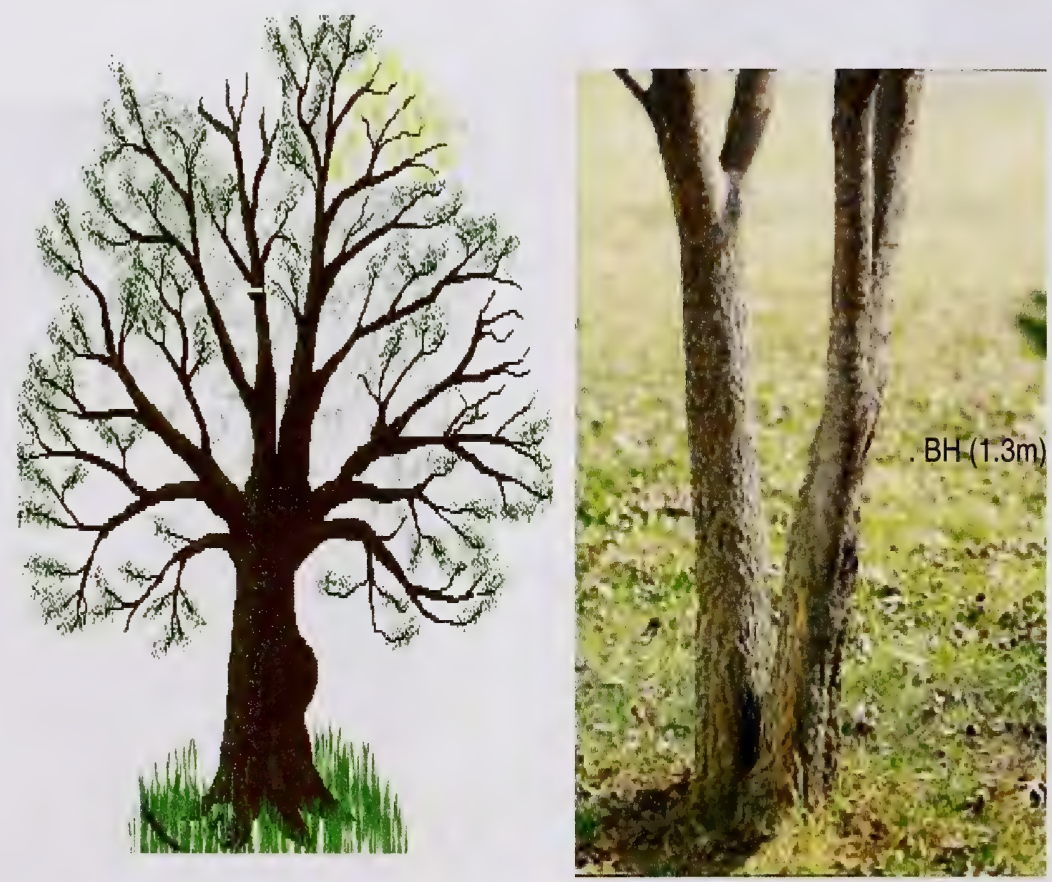

This tree would be considered a fork if fork occurred above the DBH FIGURE 4.6 FORKS 


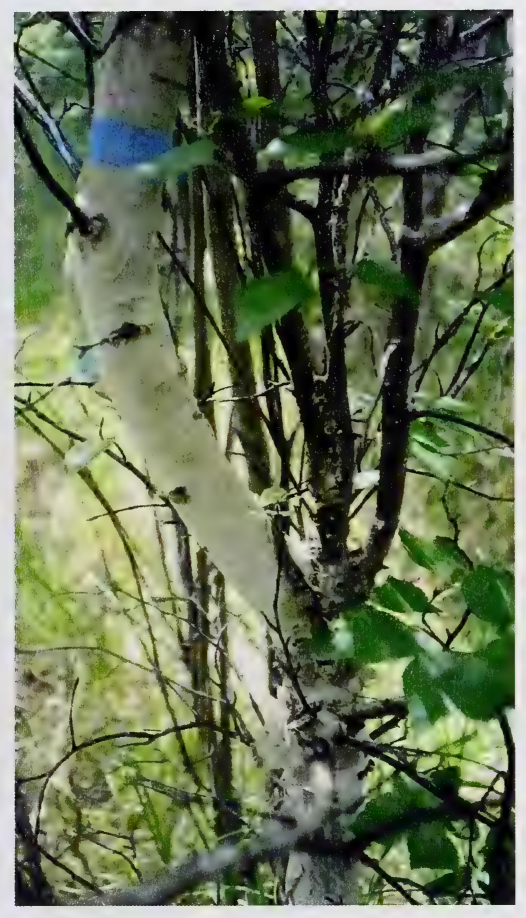

FIGURE 4.7 PRONOUNCED CROOK

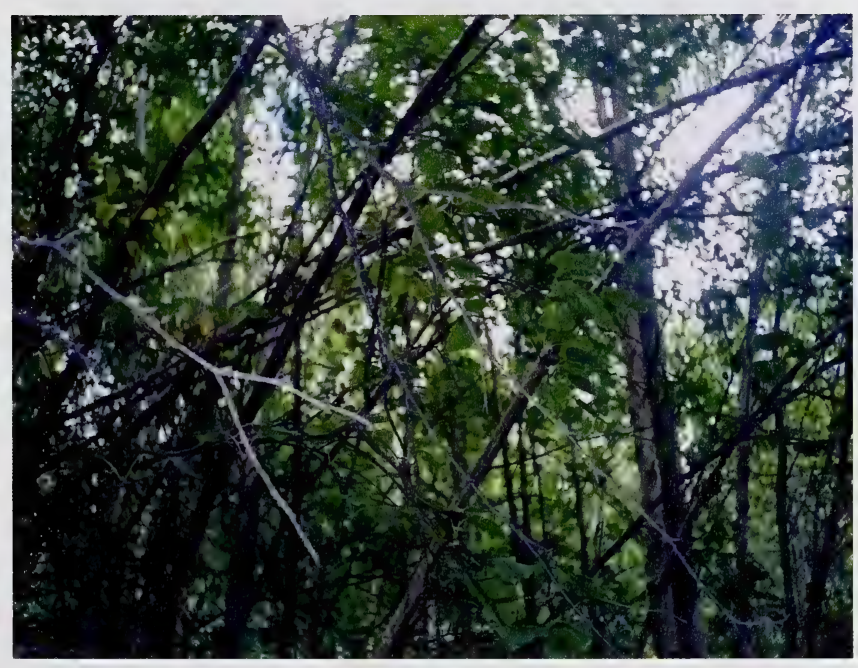

FIGURE 4.8 LEANING TREE 


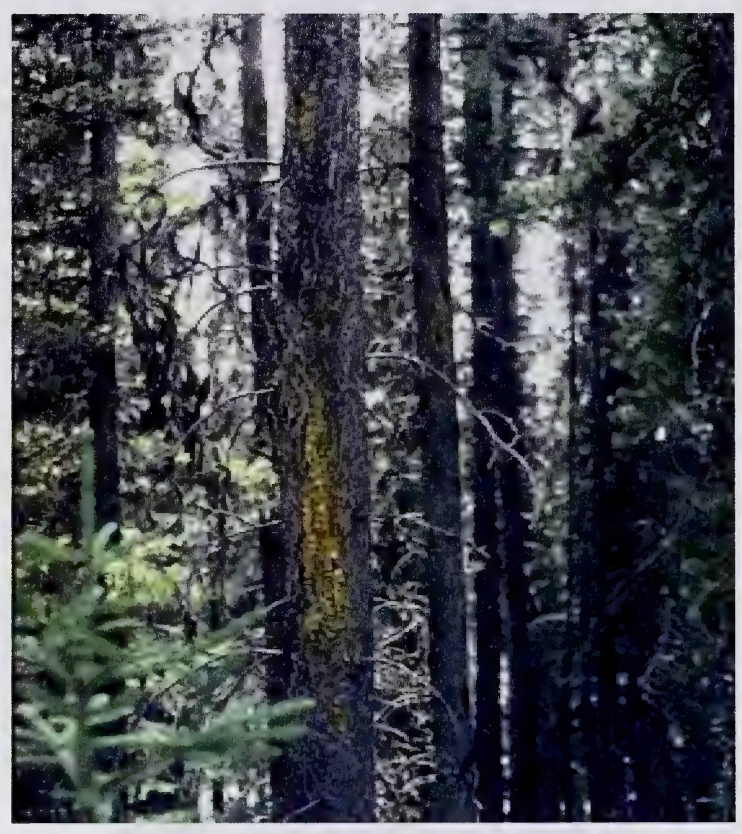

FIGURE 4.9 ATROPELLIS CANKER

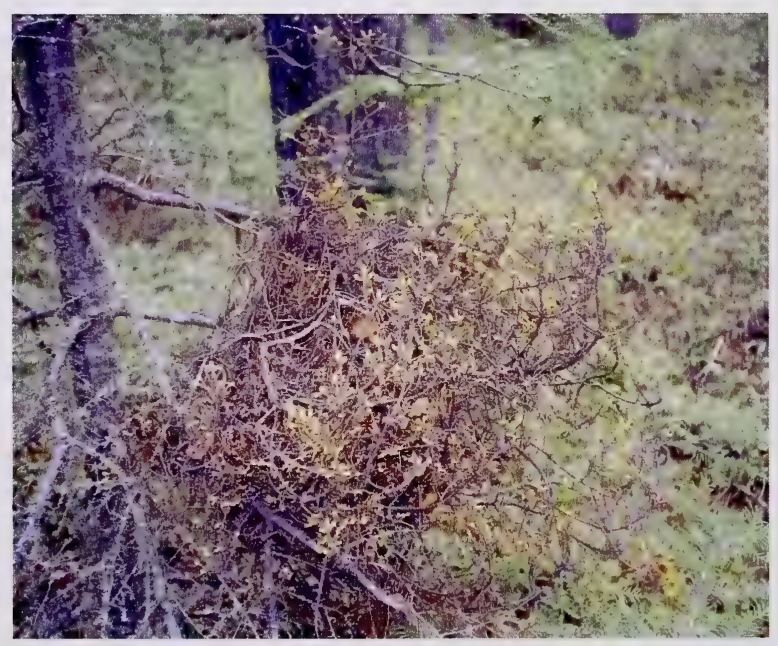

FIGURE 4.10 WITCHES ON SPRUCE 

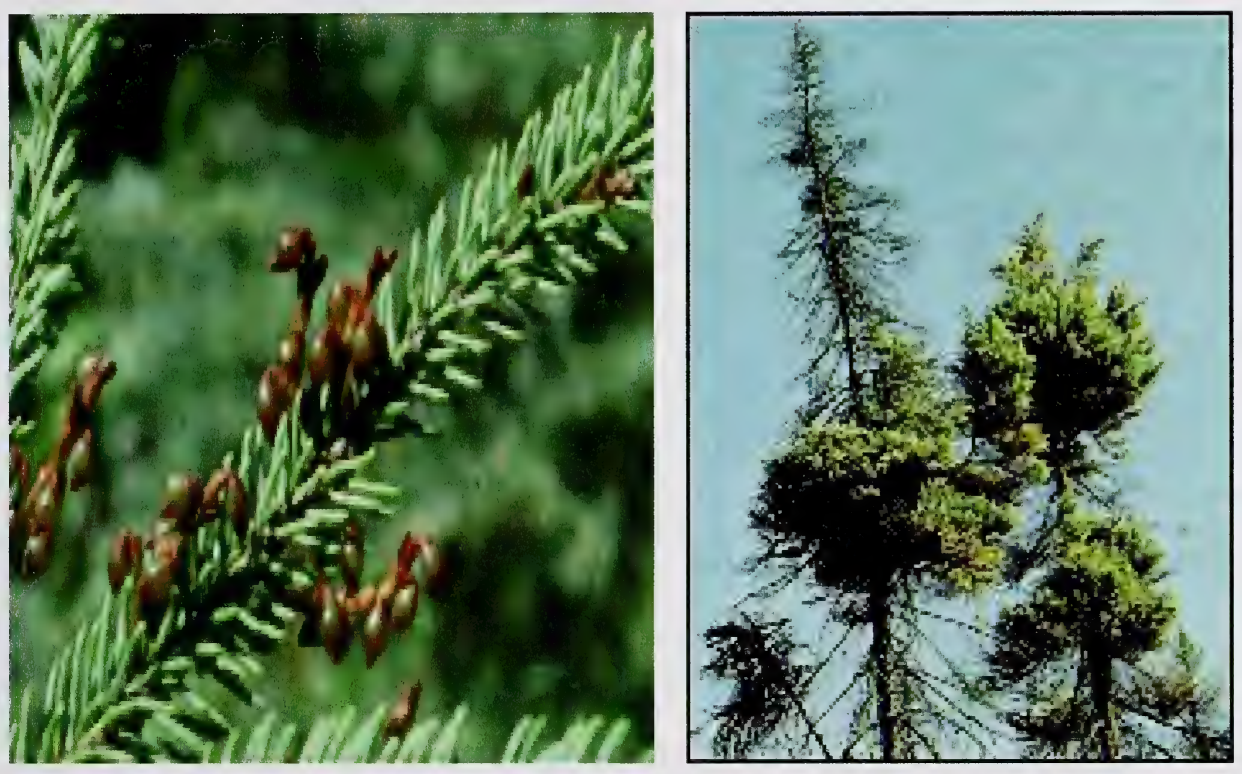

FIGURE 4.11 MISTLETOE 


\section{Instructions}

Step 1: Divide live cronw into thirds.

Step 2: rate each third separately. Give each third a rating of 0,1 , or 2 as described below.

0 - No visible infections

1 - Light infection (half or less of total branches in the third infected)

2 - Heavy infection (more than half of total branches in the third infected)

Step 3: Finally, add ratings of thirds to obtain rating for total tree.

\section{Example}

If this third has no visible infections, its rating is 0 .

\section{FIGURE 4.12 INSTRUCTIONS AND EXAMPLE OF THE USE OF THE 6 CLASS MISTLETOE RATING SYSTEM (HAWKSWORTH 1961, 1977)}

\section{CODES}

91 One of the $1 / 3$ sections has light infection (1) + other $2 / 3$ have no visible infections.

92 Two of the $1 / 3$ sections has light infection (10) + or one $1 / 3$ section ahs a heavy infection only.

93 All three of the $1 / 3$ sections has light infection (1) + or one $1 / 3$ section has a heavy infection, one has a light infection + last $1 / 3$ has no infection.

94 If total ratings $=4$ then this code is used.

95 If total ratings $=5$ then this code is used.

96 If total ratings $=6$ then this code is used. 


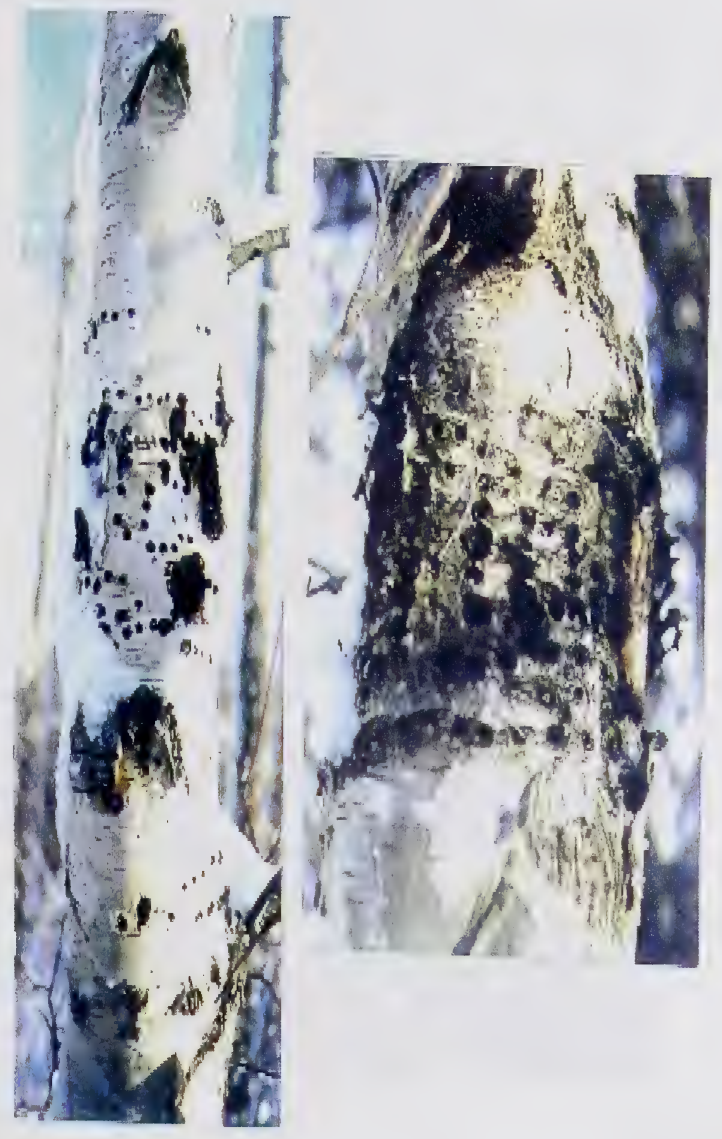

FIGURE 4.13 GENERIC WOODPECKER

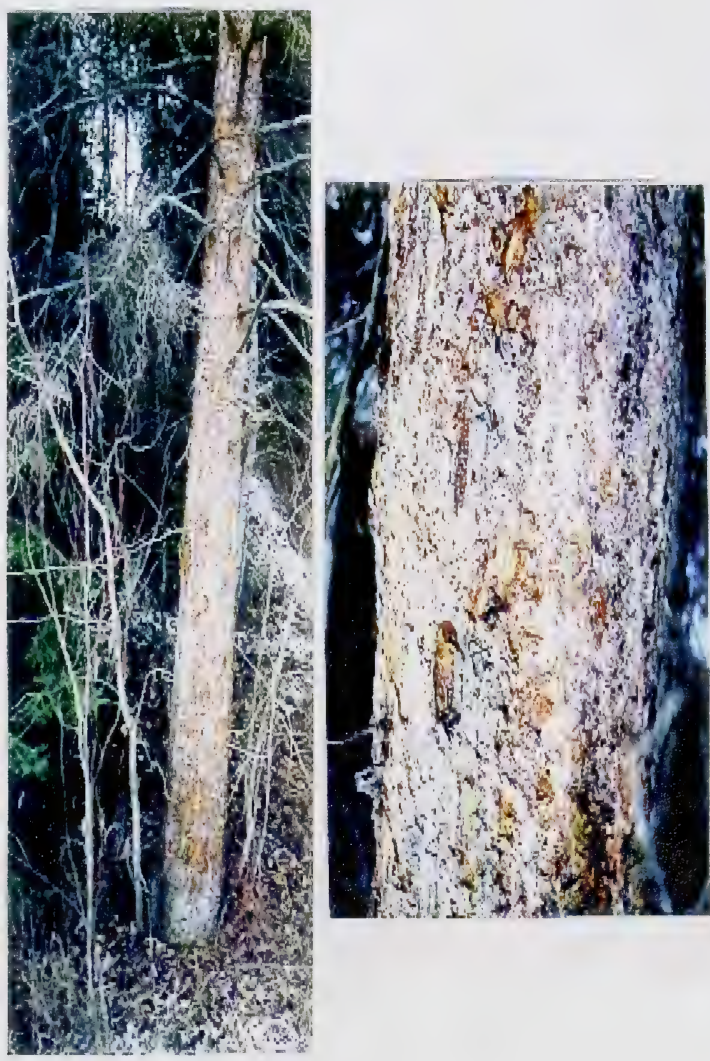



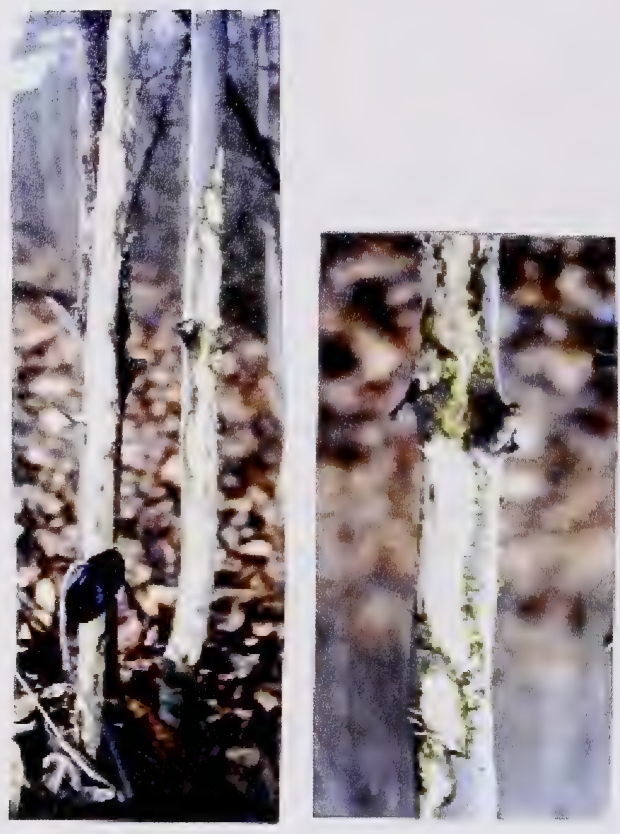

FIGURE 4.15 SMALL MAMMAL FEEDING ON TREE BOLE

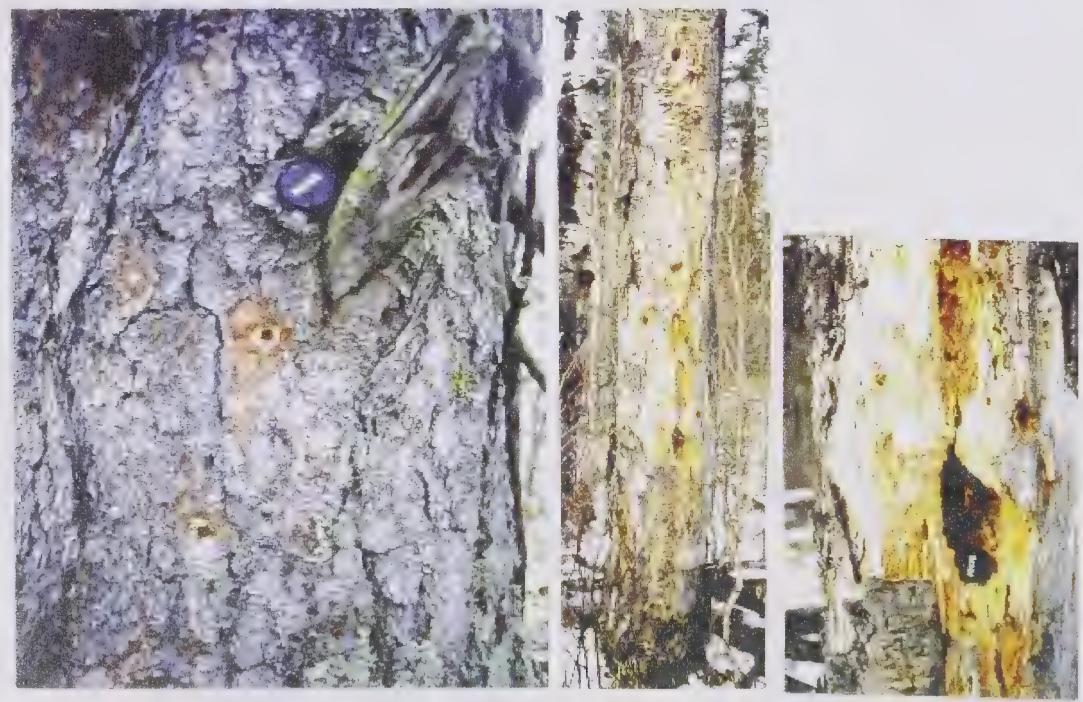

FIGURE 4.16 EXCAVATIONS BY WOODPECKERS 


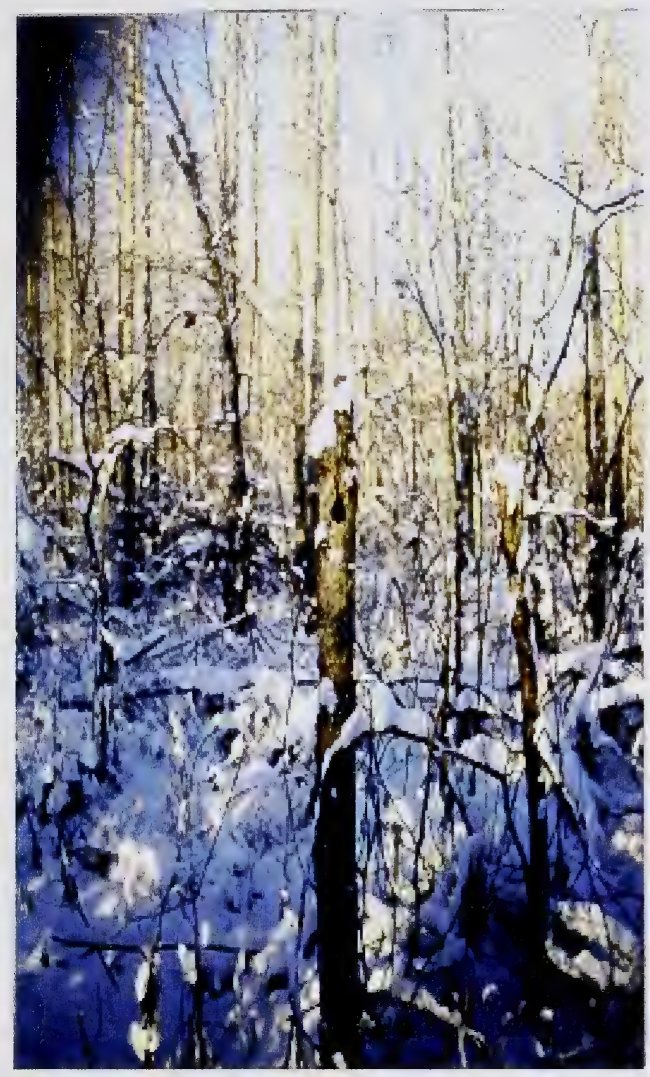

FIGURE 4.17 SMALL CAVITY

FIGURE 4.18 LARGE CAVITY

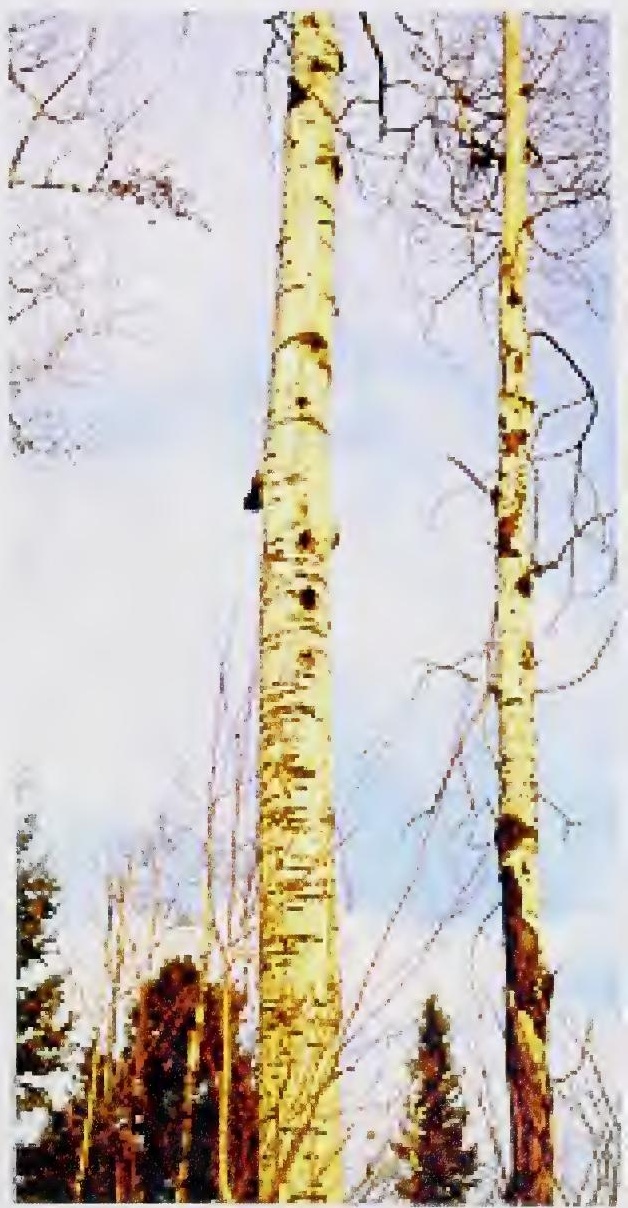




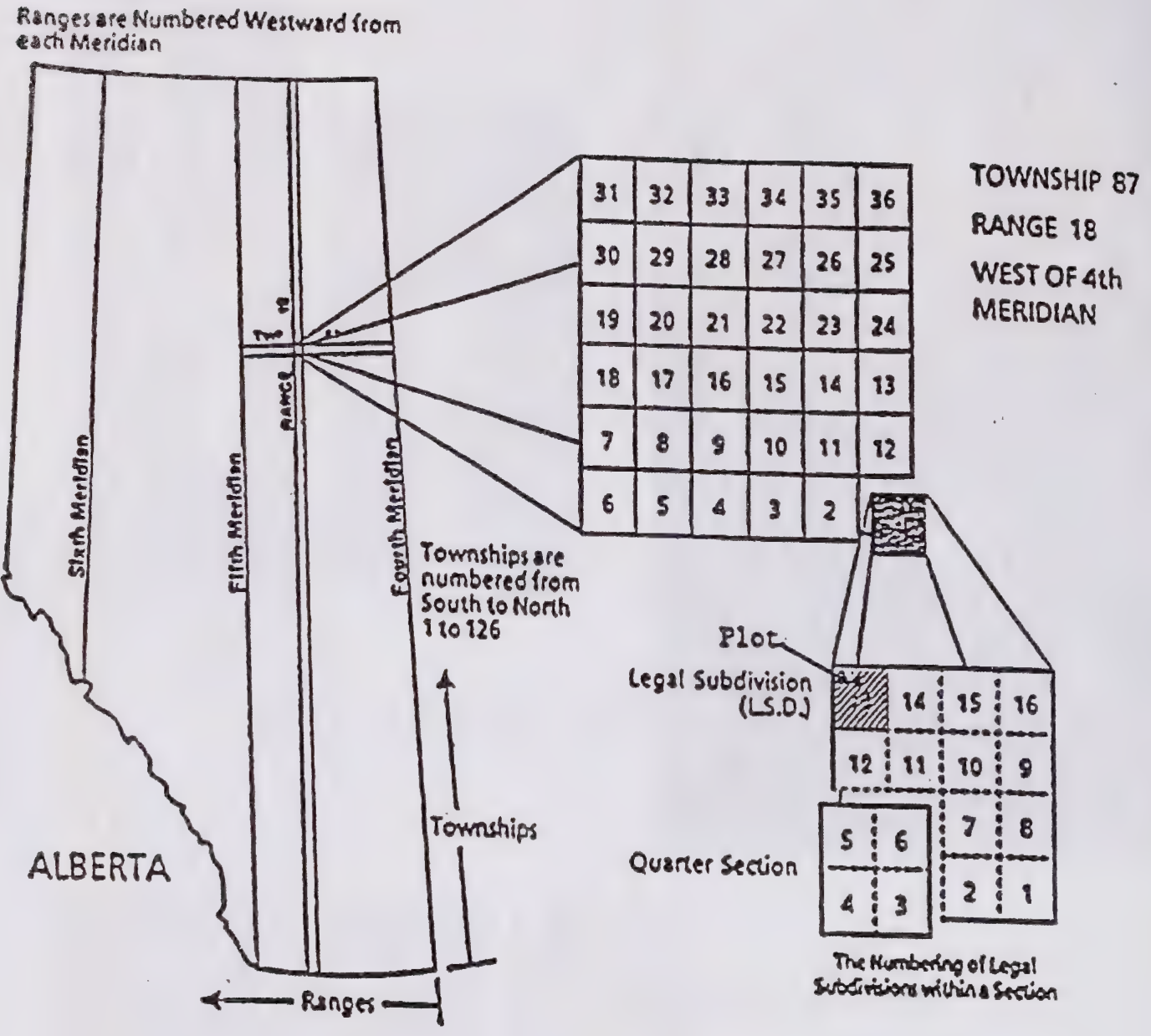

FIGURE 4.19 ALBERTA SURVEY SYSTEM ${ }^{2}$

${ }^{2}$ Alberta Bureau of Surveying and Mapping. 1986 Maps of Alberta Catalogue 1986-87. Government of Alberta ENR No. Ref 1186 pp.iv. 


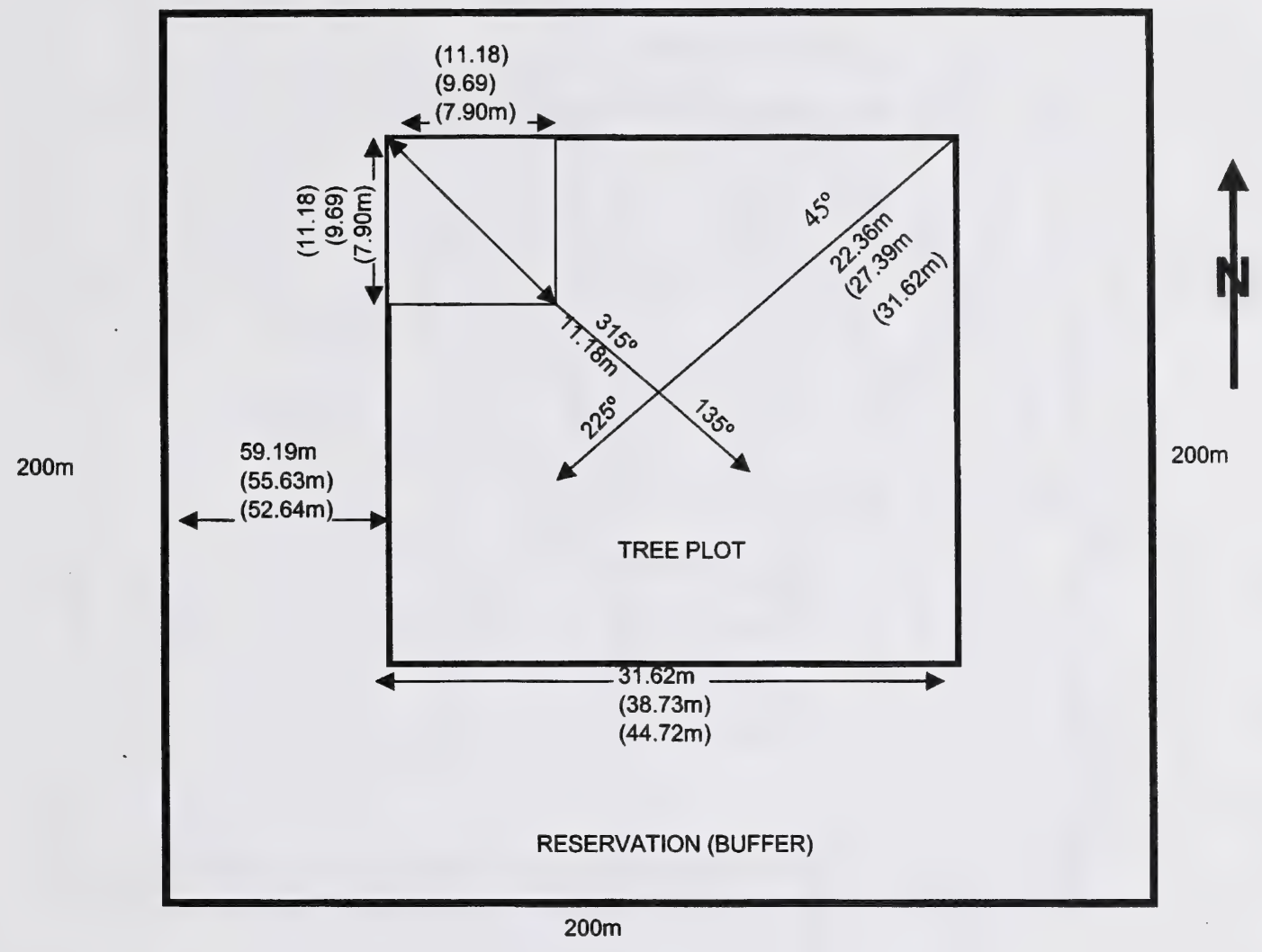

FIGURE 4.20 PLOT BOUNDARIES 


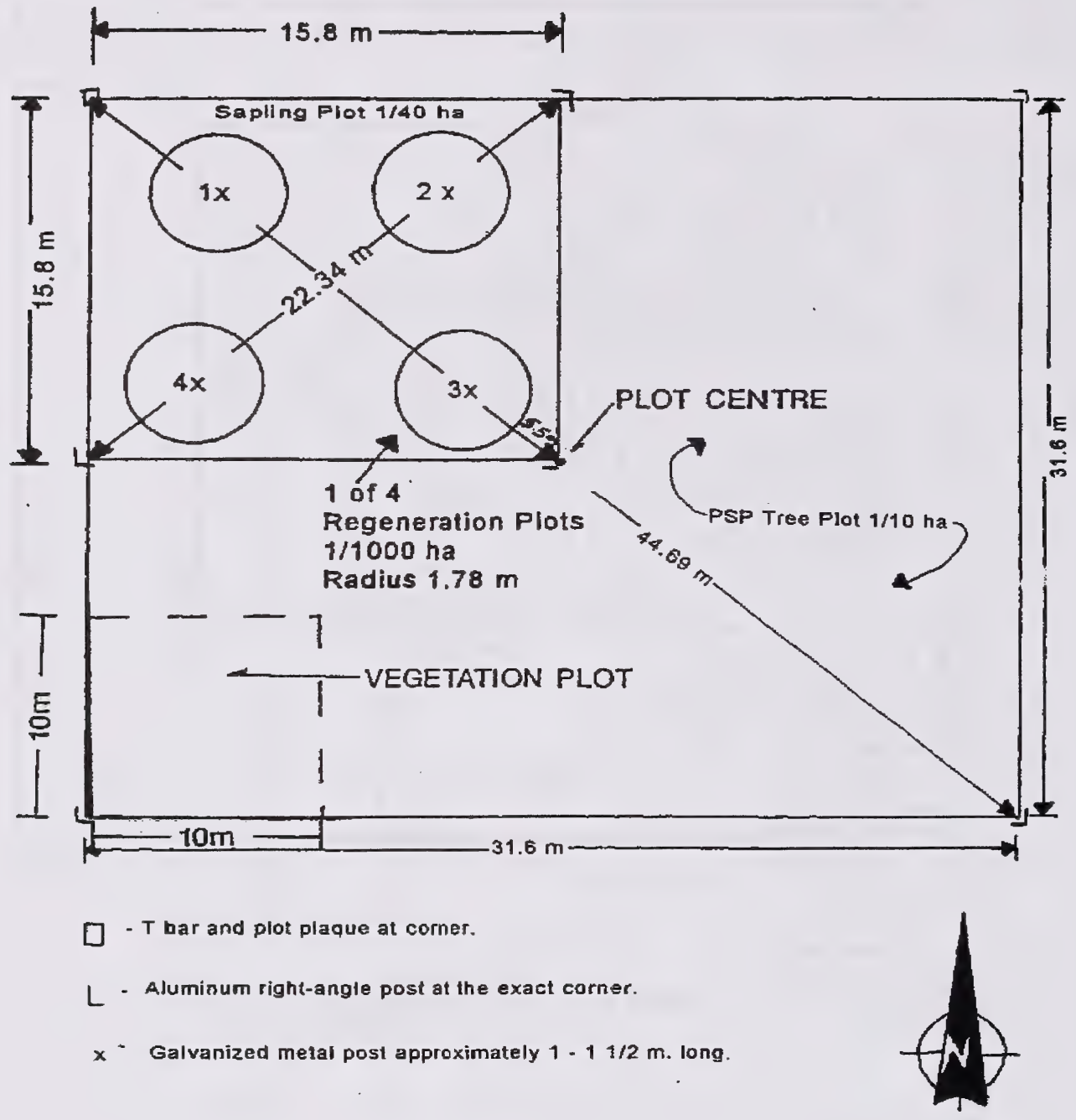

FIGURE 4.21 STAND DYNAMICS PLOT LAYOUT 


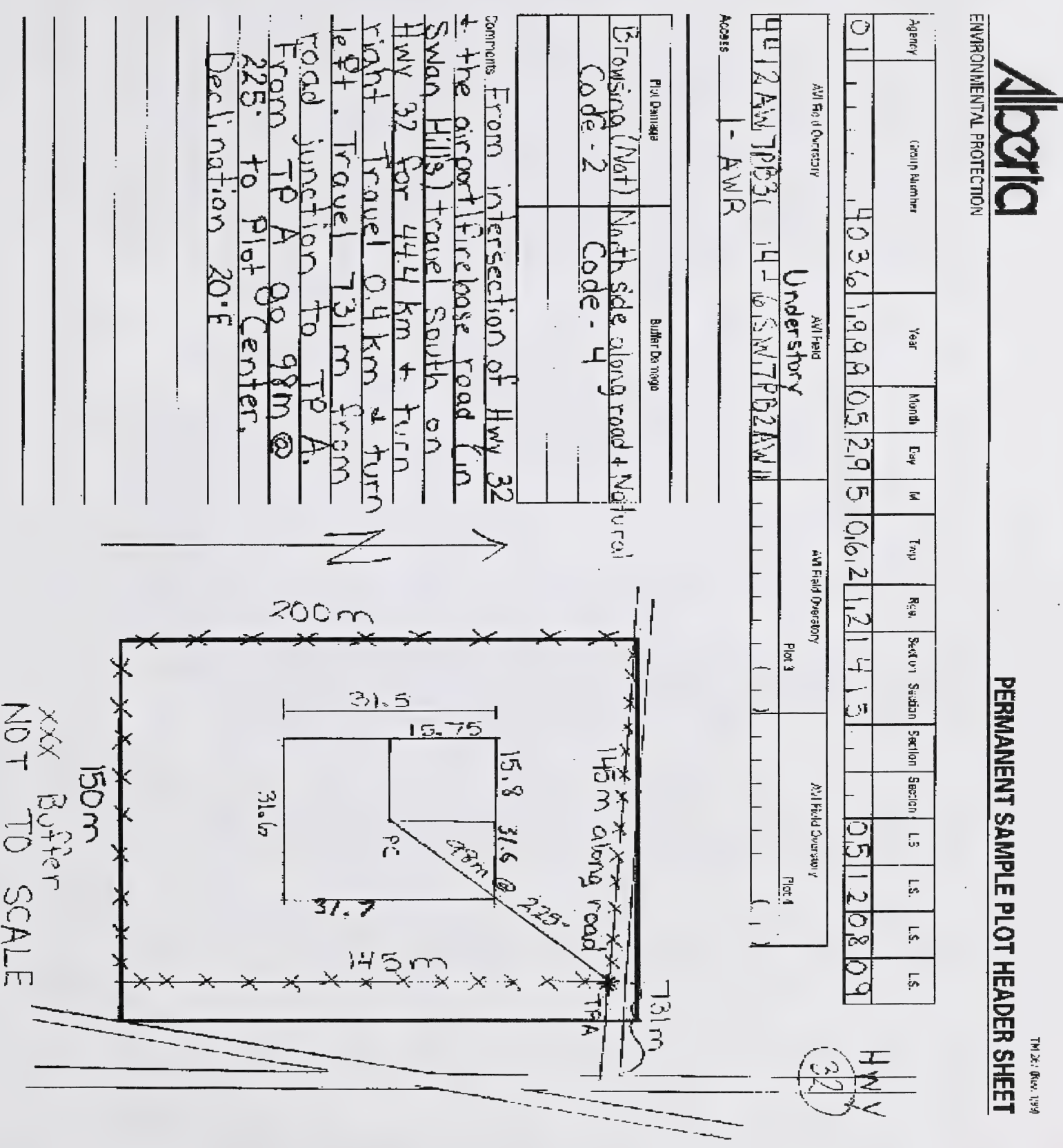

FIGURE 4.22 PLOT MAINTENANCE REPORT 
1

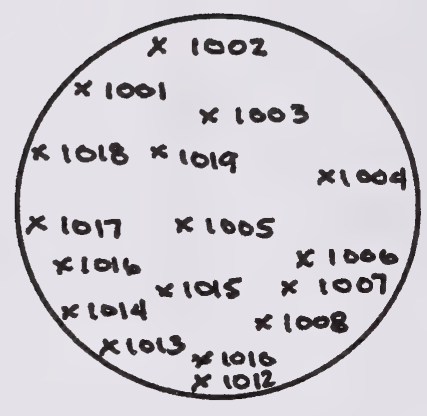

4

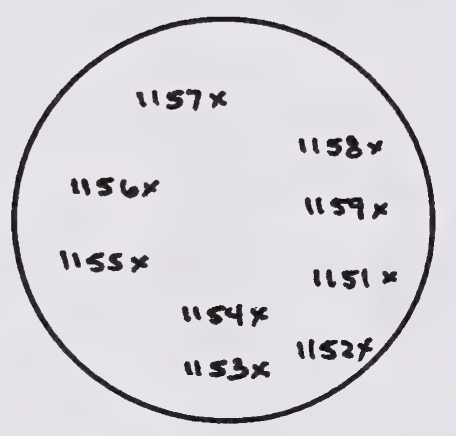

FIGURE 4.23 SEEDLING NUMBERING
2

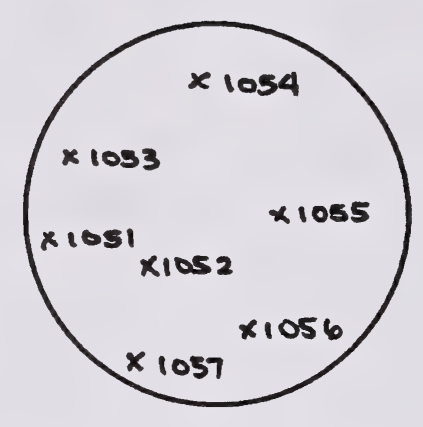

3

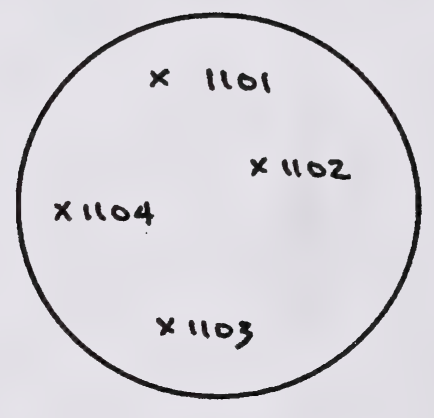




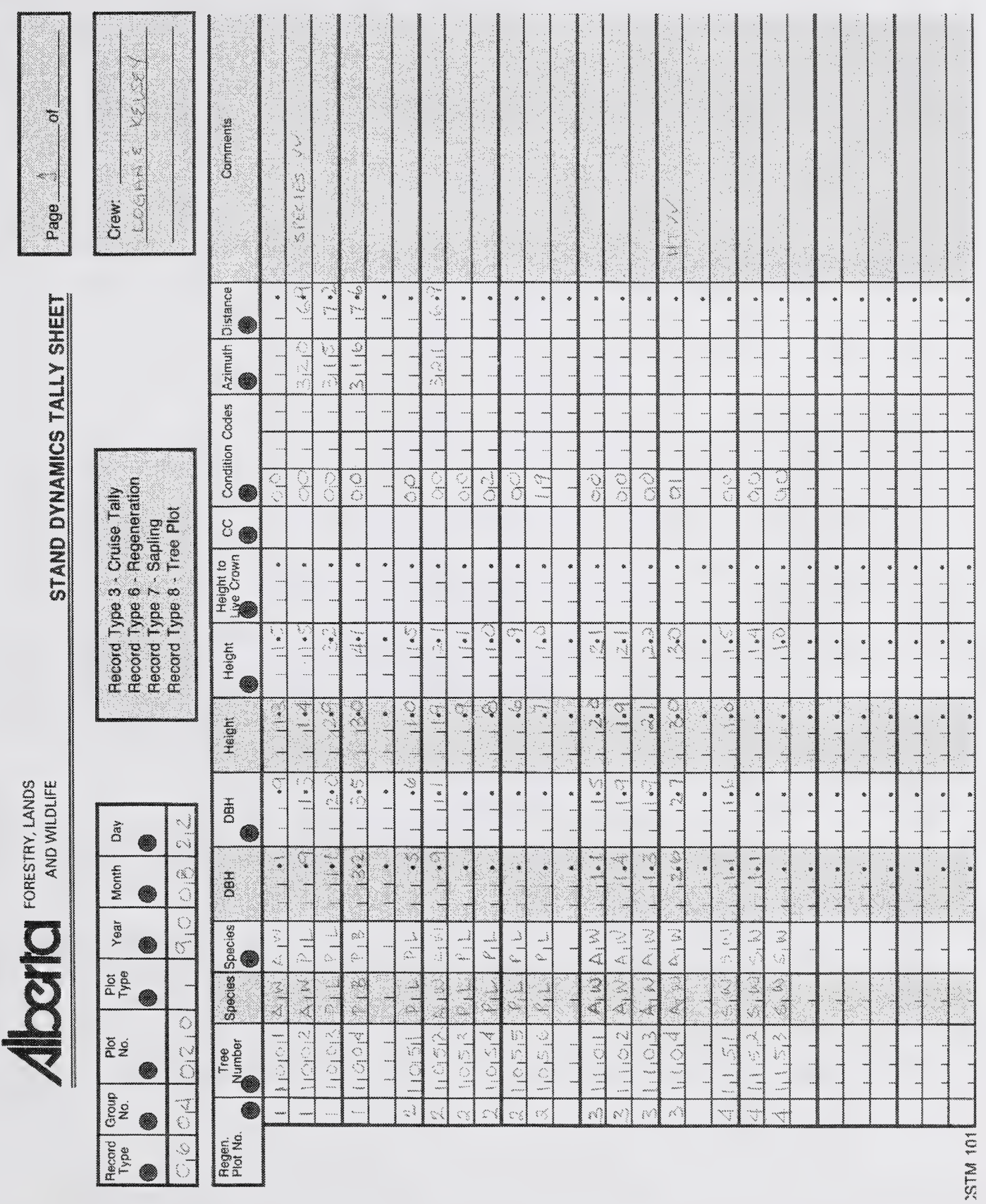

FIGURE 4.24 STAND DYNAMICS TALLY SHEET (CSTM 101) RECORD TYPE 6 


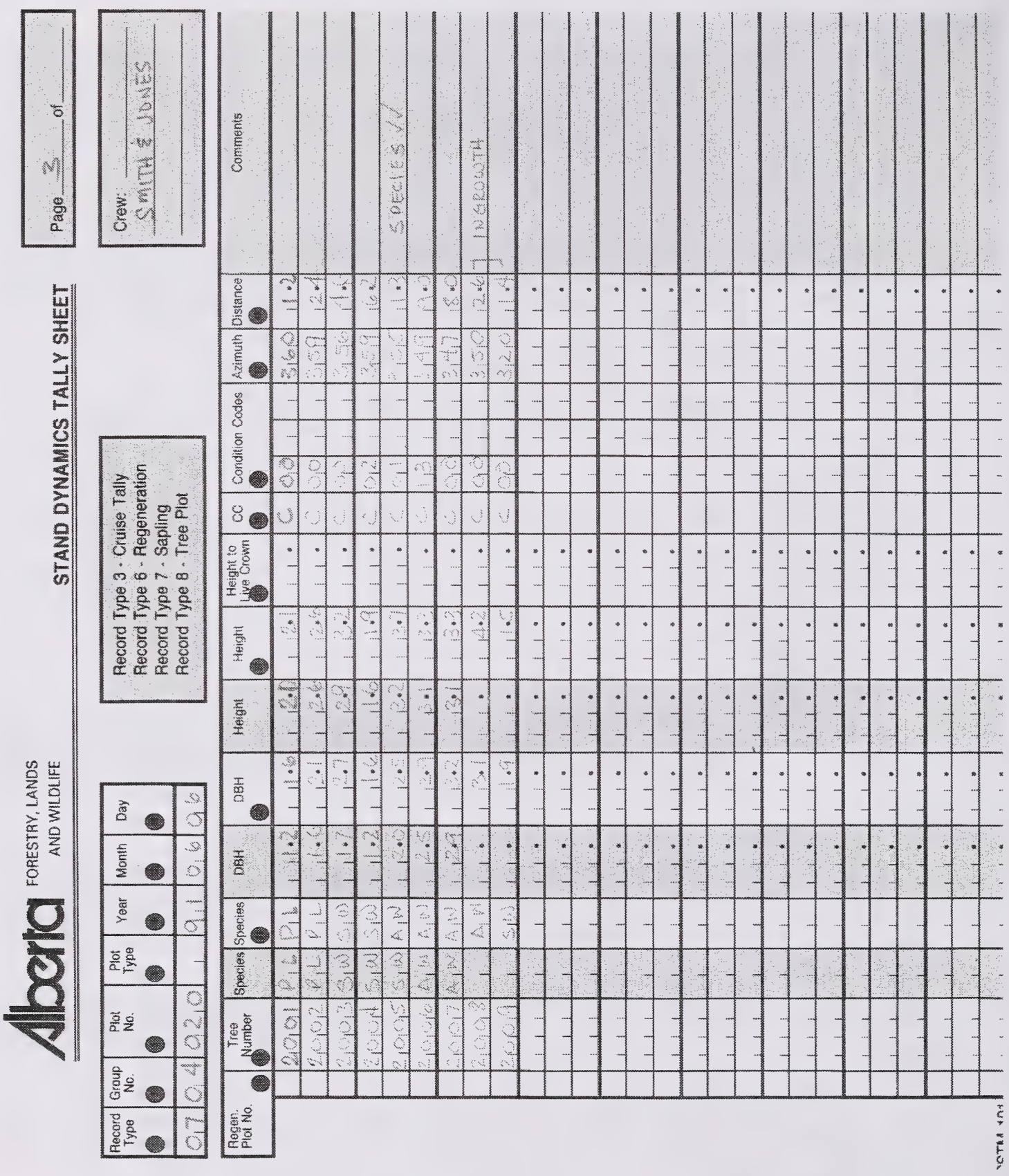

FIGURE 4.25 STAND DYNAMICS TALLY SHEET (CSTM 101) RECORD TYPE 7 (SAPLINGS) 


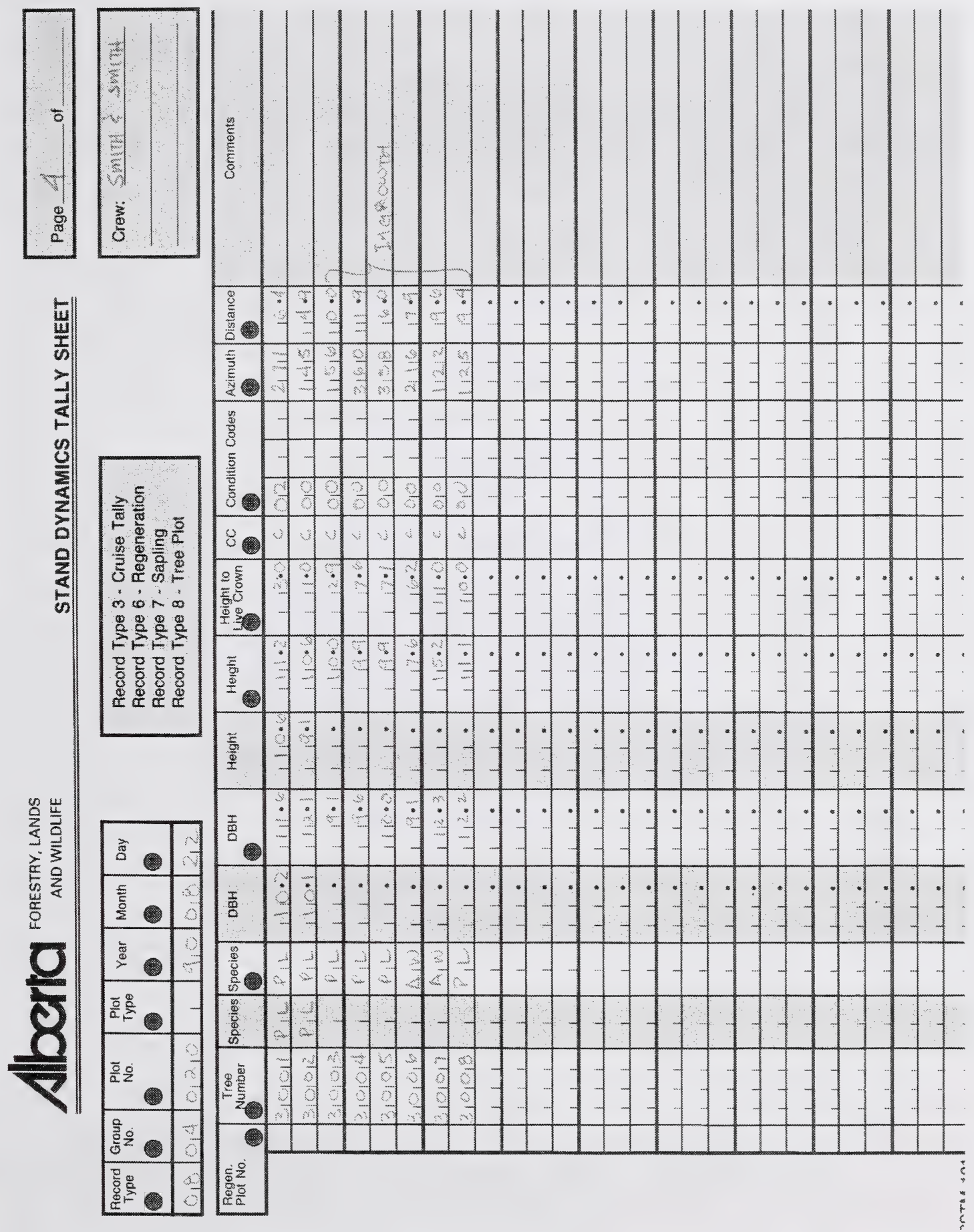

FIGURE 4.26 STAND DYNAMICS TALLY SHEET (CSTM 101) RECORD TYPE 8 (TREE PLOT) 

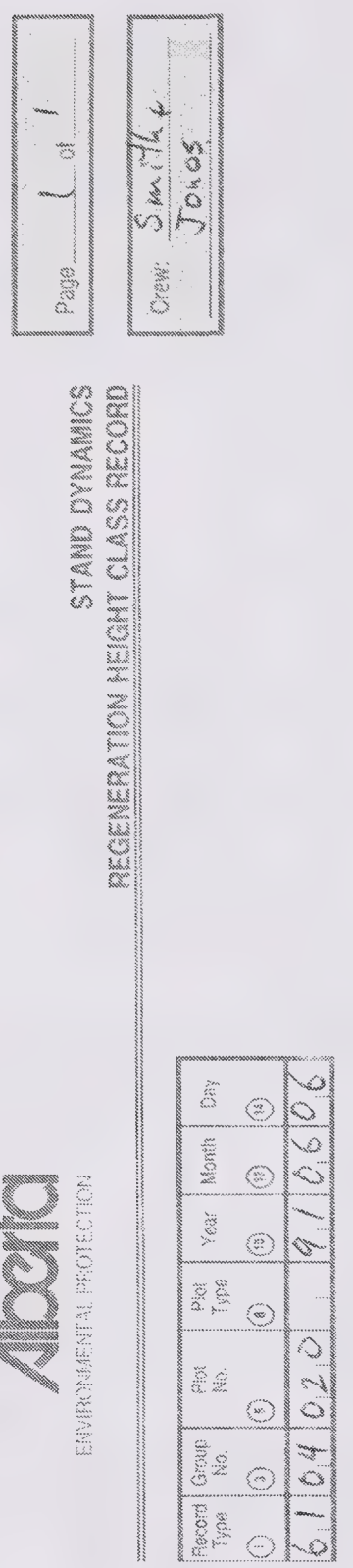

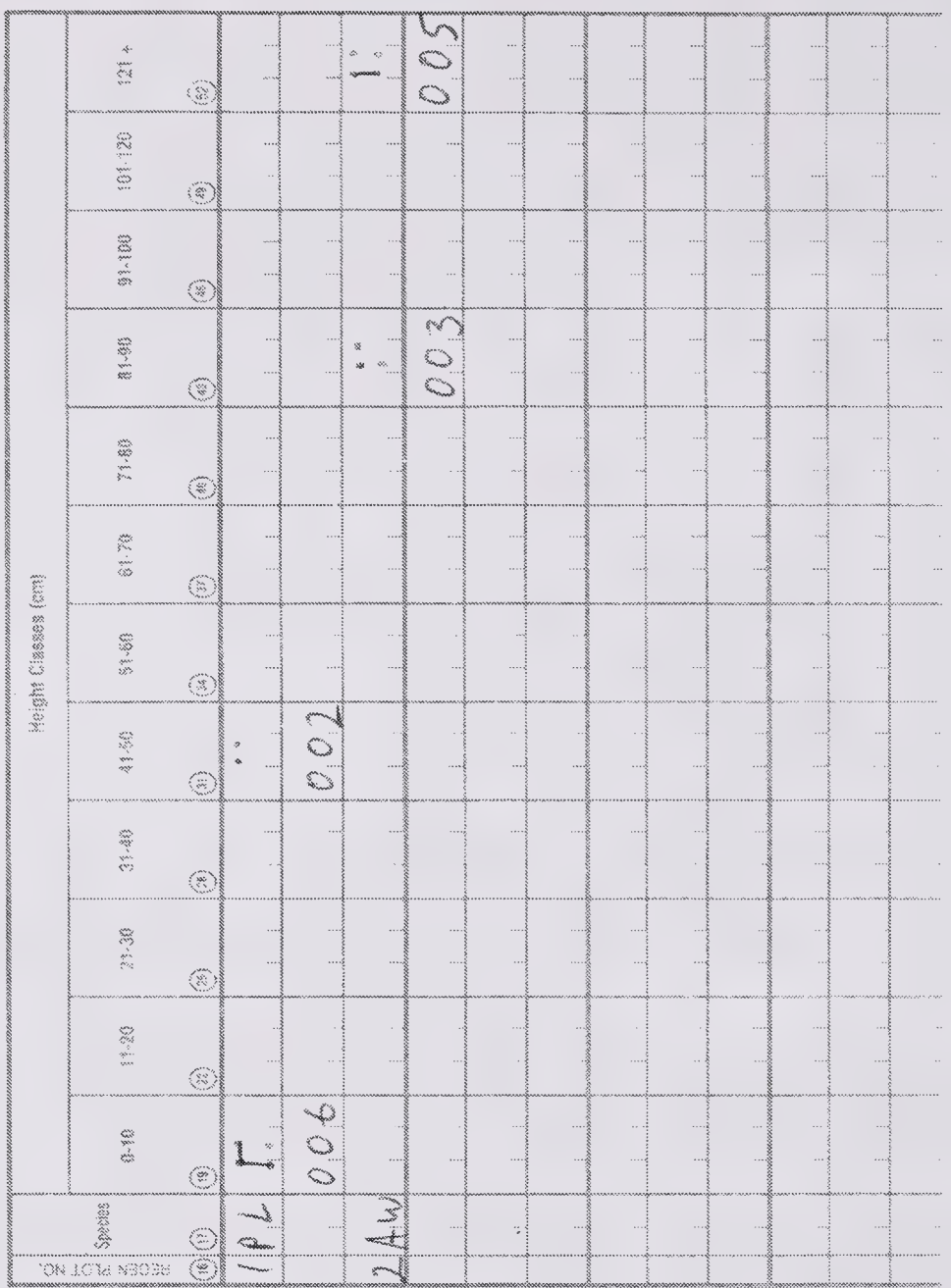

FIGURE 4.27 STAND DYNAMICS REGENERATION HEIGHT CLASS RECORD (CSTM 100) RECORD TYPE 61 
FORESTRY, LANDS

AND WILDUIFE

STAND DYNAMICS VEGETATION

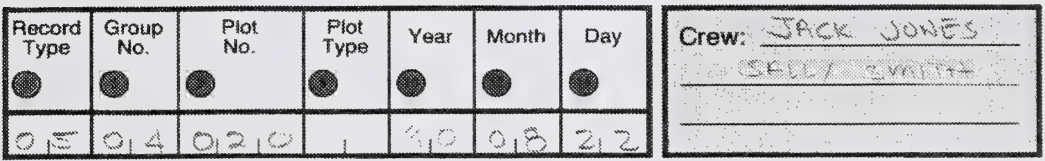

Page of

Parent Vegetation - R Type 4

Plot Vegetation - $A$ Type 5

\begin{tabular}{|c|c|c|c|c|c|c|c|c|c|c|c|}
\hline \multirow[b]{3}{*}{ FIELD NAME } & \multirow{2}{*}{\multicolumn{2}{|c|}{ TAEES }} & \multirow[b]{2}{*}{$\begin{array}{c}\text { TALL } \\
\text { SHRUBS }\end{array}$} & \multirow[b]{2}{*}{$\begin{array}{c}\text { LOW } \\
\text { SHRUES }\end{array}$} & \multirow[b]{2}{*}{$\begin{array}{l}\text { GROUND } \\
\text { SHRUBS }\end{array}$} & \multirow[b]{2}{*}{$\begin{array}{c}\text { TOTAL } \\
\text { SHRUBS }\end{array}$} & \multirow[b]{2}{*}{ HERBS } & \multirow[b]{2}{*}{ GRASS } & \multirow[b]{2}{*}{$\begin{array}{l}\text { MOSS } \\
\text { LICHEN }\end{array}$} & \multirow{2}{*}{\multicolumn{2}{|c|}{$\begin{array}{c}\text { TOTAL } \\
\text { ALL }\end{array}$}} \\
\hline & & & & & & & & & & & \\
\hline & $0 \%$ & क्ष & $0^{\%}$ & $\%$ & $0^{\%}$ & \begin{tabular}{|c|c|}
$9 / 3$ & 5 \\
& 0 \\
\end{tabular} & \begin{tabular}{l|l}
0 & $\%$ \\
& 0 \\
\end{tabular} & \begin{tabular}{l|c|}
0 & 8 \\
0 & 8 \\
\end{tabular} & $\begin{array}{lll}0 & \% & \\
& 0 \\
\end{array}$ & $0^{\circ / \%}$ & 莺 \\
\hline$P_{1}, N: S=6,0, \mathrm{~m}$ & \pm & 2 & I & $\perp$ & \pm & 11 & 1 & & 11 & & \\
\hline$\rho_{1}, 0, \rho, V, T, R_{1}$, & & 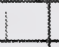 & 442 & 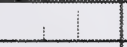 & 11 & 1 & 11 & 1 & 11 & & \\
\hline $1,10,1,2,0$ & 1 & $L$ & 10 & 11 & 11 & 1 & 1 & 11 & 11 & & L \\
\hline 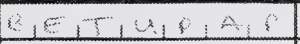 & 1 & 1 & 10 & 11 & +1 & 1 & 11 & 11 & 1 & & 7 \\
\hline $1,13=1$ & 1 & 1 & 1 & +1 & 1 & 11 & 11 & 11 & +1 & 1 & 1 \\
\hline A, & 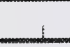 & $\perp$ & 110 & 1 & 11 & 11 & 11 & 1 & 11 & & $\perp$ \\
\hline $5,5+1,15,10$ & & 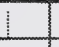 & 1012 & 1 & 11 & 11 & 11 & 1 & 11 & & 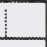 \\
\hline $0,1,8,5,2,0,6$ & & 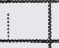 & 11 & 012 & 11 & 11 & +1 & 1 & 11 & & - \\
\hline $1,1,3, U, g, 0,0$ & & 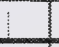 & 11 & 112 & 11 & 11 & -1 & +1 & 1 & & 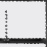 \\
\hline$: \quad 1,11$ & 1 & 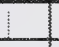 & 11 & 15 & 11 & 11 & 11 & 1 & 11 & & 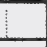 \\
\hline $4: 1,1, x, 2, \infty, 12$ & 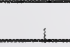 & $\perp$ & +1 & +1 & 112 & 11 & 11 & 1 & 11 & & 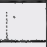 \\
\hline 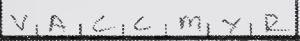 & + & 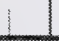 & +1 & +1 & 112 & 1 & -1 & 1 & $=1$ & & L \\
\hline$y_{1} s_{1} c_{1}, y_{1}, 5$ & & 1 & 11 & 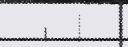 & 112 & 11 & $: 1$ & 1 & 11 & & 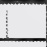 \\
\hline 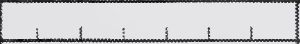 & & 1 & 1 & 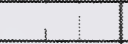 & 11 & 1 & 1 & 3 & $L$ & & 1 \\
\hline 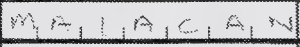 & & 1 & $L$ & 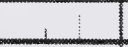 & 1 & 1 & 4012 & 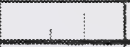 & 11 & & - \\
\hline 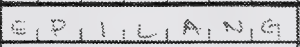 & & 1 & 1 & 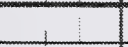 & 1 & 1 & 412 & 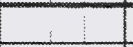 & 11 & & 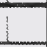 \\
\hline$p_{1}, R_{1}, b_{1}=D_{2}$ & & 1 & 1 & 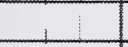 & 1 & 11 & $9 / 2$ & 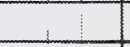 & +1 & & 1 \\
\hline $1,1: 1: 1$ & & 1 & 1 & 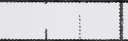 & 1 & 1 & 1 & 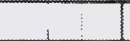 & 1 & & 1 \\
\hline$F_{1} n_{1} \alpha_{3}: \alpha_{1}: 1,2$ & & 1 & 1 & 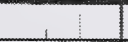 & 1 & 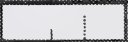 & $9 / 2$ & 1 & 1 & & 1 \\
\hline$M_{1} R_{1} n, n_{1}, v_{2}$ & & $\perp$ & $\perp$ & 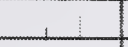 & $\perp$ & $\perp$ & 일 & 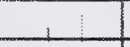 & 11 & & 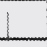 \\
\hline $1: 1: 1: 1$ & & $\perp$ & $L$ & 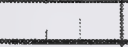 & 1 & 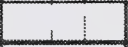 & 1 & 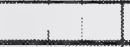 & 1 & & $L$ \\
\hline$B_{1} x_{1}: a_{10}=$ & & 1 & $\perp$ & 1 & $\perp$ & 1 & 1 & 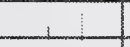 & 1512 & & \\
\hline$P_{1} E_{1} U_{1}:<, 4$ & & 1 & 1 & 1 & 1 & $\perp$ & $\perp$ & 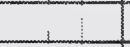 & .212 & & - \\
\hline $4,1+1,5: 4: 1$ & & 1 & $\perp$ & $\perp$ & 1 & 4 & $L$ & 1 & 812 & & - \\
\hline $11: 1:$ & & $L$ & $L$ & 1 & 1 & 1 & 1 & 1 & 11 & & 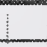 \\
\hline 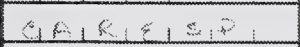 & & 1 & $\perp$ & 1 & 1 & 1 & 1 & 812 & $L$ & & 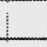 \\
\hline $11+1:$ & & $\perp$ & $\perp$ & $L$ & $\perp$ & $\perp$ & $\perp$ & 1 & $\perp$ & & 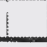 \\
\hline 11111 & & 1 & $\perp$ & 1 & $\perp$ & 1 & 1 & 1 & 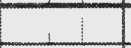 & & $L$ \\
\hline 11111 & + & 1 & $\perp$ & $i$ & 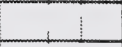 & 1 & 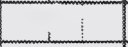 & 1 & 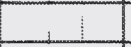 & & $L$ \\
\hline 11111 & & 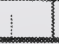 & $=$ & 1 & 1 & 1 & 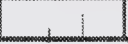 & 1 & $\perp$ & & 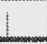 \\
\hline (1) Record Type & & & & $\mathrm{Com}$ & nments & & & & & & \\
\hline C BROWSING \& G & RAZIN & & & & & & & & & & \\
\hline C DISEASE $>20 \%$ & & & & & & & & & & & \\
\hline C OTHER - & & & & & & & & & & & \\
\hline
\end{tabular}




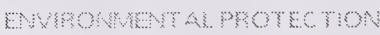

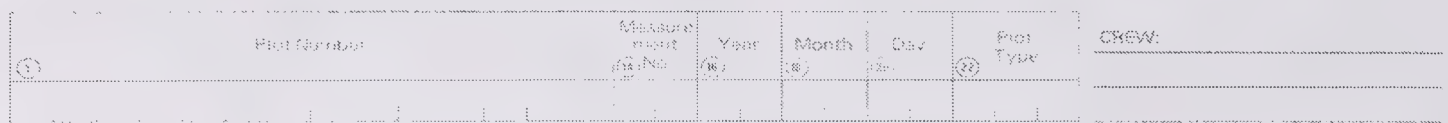

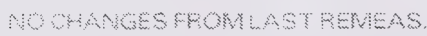

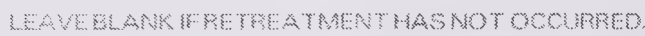

STANOTENWO YEAROF RETREATMENT

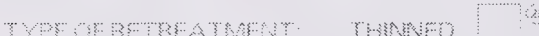

Dec on:. Y

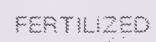

WATE: $:$ Ka/ha

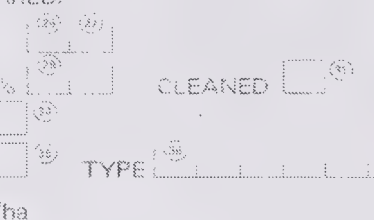

2. शEए aNTEO:

spremes

(4)

sтockng

DAE

(3)

3. WEATHER NAWUEALDAMOE

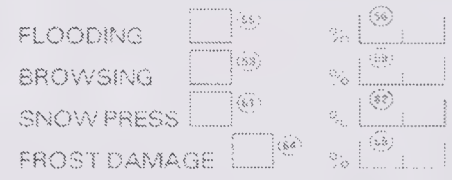

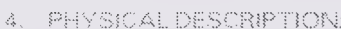

WINDEOXV INTEEPLOT

EXFOSED MINERAL SOIL

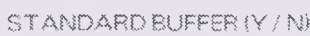

SAPUIVS

भलEह

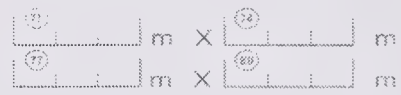

FIGURE 4.29 PLOT RETREATMENT REPORT (RECORD TYPE 9) 


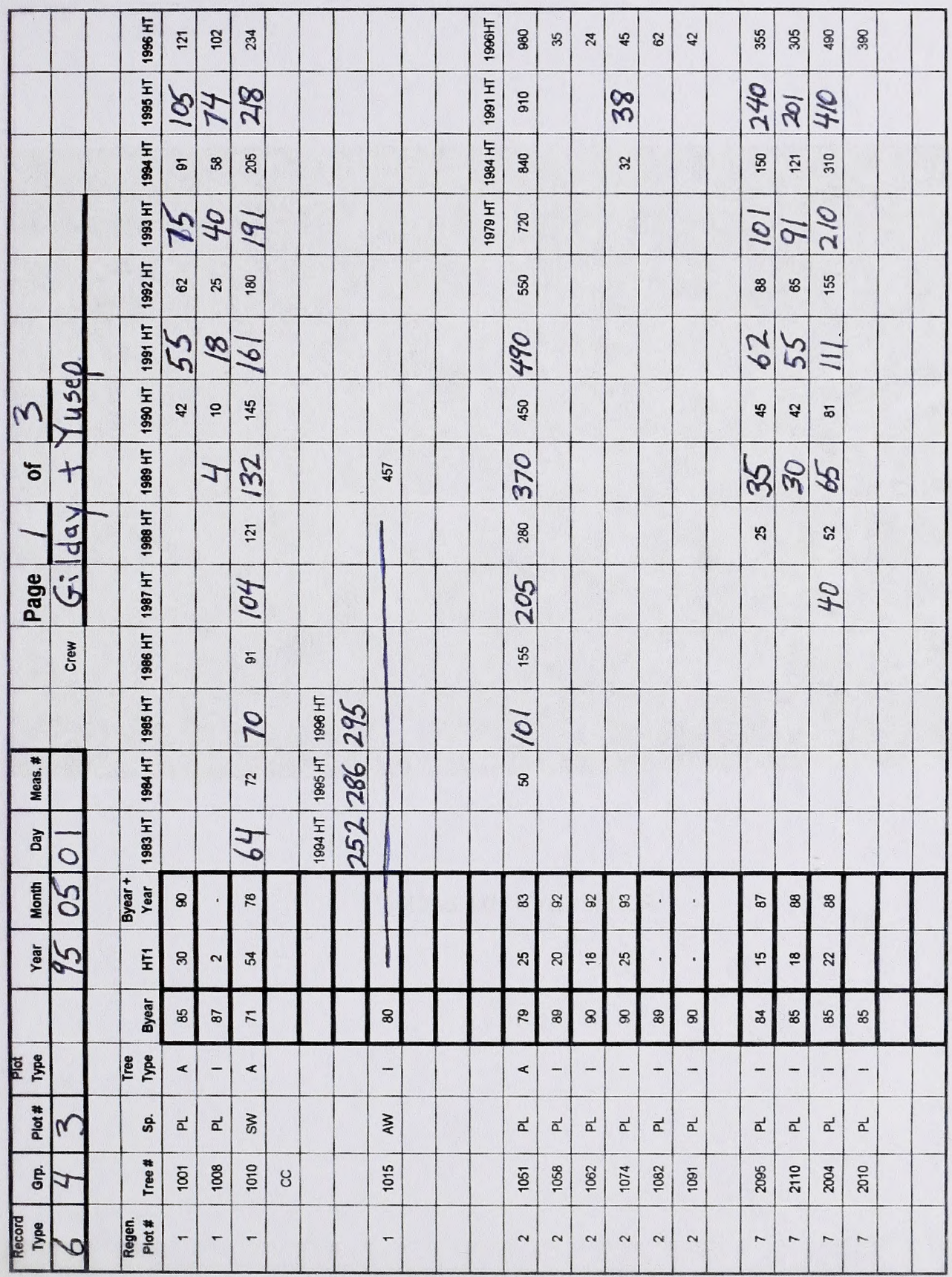

FIGURE 4.30 STAND DYNAMICS TREE AGE TALLY SHEET 


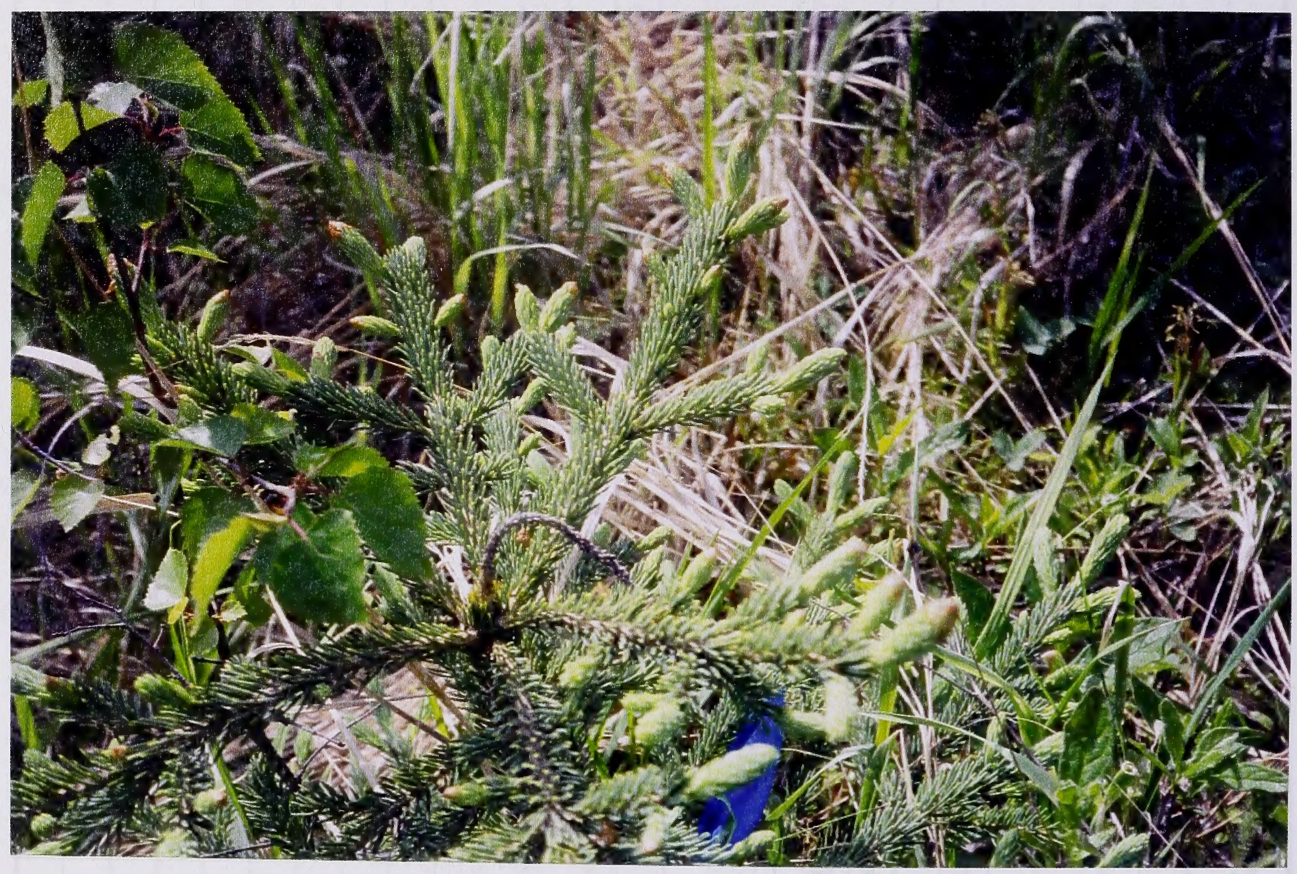

FIGURE 4.31 DIE BACK 

